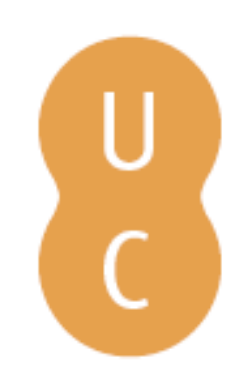

pnmbalina

\title{
Ricœuriana 1: a atualidade de Paul Ricœur numa perspetiva Ibero-Americana
}

$\begin{array}{ll}\text { Autor(es): } \quad \text { Marcelo, Gonçalo (ed.); Arias, César Correa (ed.); Lavelle, Patrícia (ed.); } & \text { Moratalla, Tomás Domingo (ed.) }\end{array}$

Publicado por: Imprensa da Universidade de Coimbra

URL

persistente: URI:http://hdl.handle.net/10316.2/43630

DOI: $\quad$ DOI:https://doi.org/10.14195/978-989-26-1516-5

Accessed : $\quad$ 8-Dec-2021 17:28:46

A navegação consulta e descarregamento dos títulos inseridos nas Bibliotecas Digitais UC Digitalis, UC Pombalina e UC Impactum, pressupõem a aceitação plena e sem reservas dos Termos e Condições de Uso destas Bibliotecas Digitais, disponíveis em https://digitalis.uc.pt/pt-pt/termos.

Conforme exposto nos referidos Termos e Condições de Uso, o descarregamento de títulos de acesso restrito requer uma licença válida de autorização devendo o utilizador aceder ao(s) documento(s) a partir de um endereço de IP da instituição detentora da supramencionada licença.

Ao utilizador é apenas permitido o descarregamento para uso pessoal, pelo que o emprego do(s) título(s) descarregado(s) para outro fim, designadamente comercial, carece de autorização do respetivo autor ou editor da obra.

Na medida em que todas as obras da UC Digitalis se encontram protegidas pelo Código do Direito de Autor e Direitos Conexos e demais legislação aplicável, toda a cópia, parcial ou total, deste documento, nos casos em que é legalmente admitida, deverá conter ou fazer-se acompanhar por este aviso.

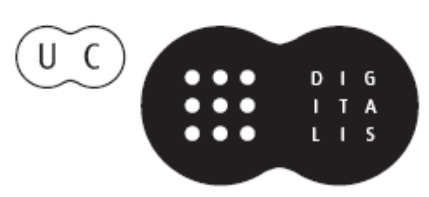


善商

Gonçalo Marcelo

César Correa Arias

Patrícia Lavelle

\#1

Tomás Domingo Moratalla COORDS.

A Atualidade

de Paul Ricour

numa Perspetiva

Ibero-Americana

Imprensa da Universidade de Coimbra

Coimbra University Press 
A Ricœuriana é uma série de livros (abrangendo monografias e volumes coletivos) disponibilizados em acesso aberto, dedicada à obra de Paul Ricœur e aberta a contribuições que também versem sobre outros autores e áreas, fomentando um permanente espírito de diálogo e interdisciplinaridade. As suas publicações abrangem diversos domínios da filosofia (estética, ética, fenomenologia, filosofia social e política, hermenêutica), mas também de disciplinas como os estudos literários, a história, a psicanálise, e a teologia, entre outras áreas relevantes para o pensamento de Ricœur. 
I

\#1

$\theta$

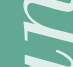

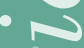

$\infty$ 


\section{EDIÇÃo}

Imprensa da Universidade de Coimbra

Email: imprensa@uc.pt

URL: http//www.uc.pt/imprensa_uc

\section{ASIER}

Associação Ibero-Americana de Estudos Ricœurianos URL: http://www.asieronline.org

\section{COORDENAÇÃO EDITORIAL}

Imprensa da Universidade de Coimbra

\section{DESIGN}

Carlos Costa

\section{INFOGRAFIA}

Imprensa da Universidade de Coimbra

\section{IMPRESSÃO}

CreateSpace

ISSN

2184-190X

\section{ISB N}

978-989-26-1513-4

\section{ISBN DIGITAL}

978-989-26-1516-5

\section{DOI}

https://doi.org/10.14195/978-989-26-1516-5

(C) NOVEMBRO 2017 , IMPRENSA DA UNIVERSIDADE DE COIMBRA 
善商

Gonçalo Marcelo

César Correa Arias

Patrícia Lavelle

\#1

Tomás Domingo Moratalla COORDS.

A Atualidade

de Paul Ricour

numa Perspetiva

Ibero-Americana

Imprensa da Universidade de Coimbra

Coimbra University Press 
RICEURIANA

Imprensa da Universidade de Coimbra / Associação Ibero-Americana de Estudos Ricœurianos

ISSN: 2184-190X

\section{DIRETORES DA SÉRIE EDITORS-IN-CHIEF}

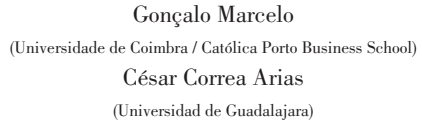

Patrícia Lavelle

(Pontifícia Universidade Católica do Rio de Janeiro) Tomás Domingo Moratalla

(Universidad Complutense de Madrid)

\section{COMISSÃO CIENTÍFICA SCIENTIFIC COMMITTEE}

Agustín Domingo Moratalla (Universidad Internacional Menéndez Pelayo, Valencia)

Alejandra Bertucci

(Universidad Nacional de La Plata)

Alfonso Mendiola Mejía

(Universidad Iberoamericana)

Ana Escríbar Wicks

(Universidad de Chile)

Aníbal Fornari

(CONICET - Universidad Católica de Santa Fe)

Beatriz Contreras Tasso

(Pontificia Universidad Católica de Chile)

Bernardo Barros Coelho de Oliveira

(Universidade Federal Fluminense)

Cláudio Reichert do Nascimento (Universidade Federal do Oeste da Bahia)

Cristóbal Holzapfel

(Universidad de Chile)

Eduardo Casarotti

(Universidad Católica del Uruguay)

Elsio José Corá

(Universidade Federal da Fronteira Sul)

Fernanda Henriques

(Universidade de Évora)

Francisco Diez Fischer

(CONICET / Academia Nacional de Ciencias de Buenos Aires)

Graciano González R. Arnaiz

(Universidad Complutense de Madrid)

Hélio Gentil

(Universidade São Judas Tadeu)

Jaime Torres Guillén

(Instituto de Filosofía A. C., México)

Jean-Luc Amalric

(CPGE Arts et Design-Nîmes / Université Montpellier 3)

Jeanne Marie Gagnebin

(Pontifícia Universidade Católica de São Paulo / UNICAMP)

José Juan Sainz Luna

(Instituto Tecnológico Autónomo de México)

José Santiago González Iñiguez

(Universidad de Guadalajara)

\begin{abstract}
Juan Masiá Clavel
(Universidad de Sophia, Japón)

Julián Molina Zambrano

(Universidad de Guadalajara)

Luís António Umbelino (Universidade de Coimbra)
\end{abstract}

Luís Manuel A. V. Bernardo (Universidade Nova de Lisboa)

Luis Miguel Arroyo Arrayás (Universidad de Huelva)

Luis Vergara Anderson (Universidad Iberoamericana)

Marcelino Agís Villaverde (Universidade de Santiago de Compostela)

Maria do Céu Zambujo Fialho (Universidade de Coimbra)

Maria João Coelho (Universidade de Coimbra)

Maria Luísa Portocarrero (Universidade de Coimbra)

María Luján Ferrari (Universidad Nacional de La Plata)

Maria da Penha Villela-Petit (Archives Husserl de Paris / C.N.R.S.)

Michel Renaud

(Universidade Nova de Lisboa)

Noeli Dutra Rossatto (Universidade Federal de Santa Maria)

Patricio Mena Malet

(Universidad Alberto Hurtado)

Paulo Jesus

(Universidade de Lisboa)

Roberto Roque Lauxen (Universidade Estadual do Sudoeste da Bahia)

Sebastián Kaufmann Salinas (Universidad Alberto Hurtado)

Walter Salles

(Pontifícia Universidade Católica de Campinas) 


\title{
RICQEURIANA 1:
}

\section{A Atualidade de Paul Ricour numa Perspetiva Ibero-Americana RICOEURIANA 1: \\ Paul Ricœur's Timeliness from an Ibero-American Perspective}

\author{
Coord. Ed.
}

Gonçalo Marcelo (Universidade de Coimbra / Católica Porto Business School)

César Correa Arias (Universidad de Guadalajara)

Patrícia Lavelle (PUC Rio)

Tomás Domingo Moratalla (Universidad Complutense de Madrid)

Resumo: O presente volume inaugural da Ricouriana - Associação Ibero-Americana de Estudos Ricourianos assinala o início de uma nova fase nos estudos ricœurianos, sobretudo no espaço ibero-americano. O dossier principal do livro é dedicado à atualidade de Paul Ricœur numa perspetiva ibero-americana. Por "perspetiva ibero-americana" entende-se simultaneamente um diagnóstico da influência que Ricœur de facto tem no panorama intelectual de diferentes países ibero-americanos e as múltiplas intersecções que podem ser feitas entre a sua obra e questões especificamente ibero-americanas. Imediatamente a seguir ao dossier temático encontra-se uma secção de varia, com um capítulo e uma recensão dedicados a aspetos do pensamento de Ricœur não diretamente ligados com o tema do dossier.

Palavras-chave: ASIER, Espaço Ibero-Americano, História da Receção, Paul Ricœur 


\begin{abstract}
This inaugural volume of Ricœuriana - Associação Ibero-Americana de Estudos Ricourianos marks the beginning of a new stage in Ricœurian studies, especially in the Ibero-American space. The main thematic issue of this book is dedicated to the timeliness of Paul Ricœur from an Ibero-American perspective, that is, both a diagnosis of the influence that Ricœur has in the intellectual landscape of several Ibero-American countries and the multiple interaction between his works and specific Ibero-American concerns issue: Following the thematic issue there is a section of varia containing a chapter and a book review dedicated to other aspects of Ricour's thought not directly related with the main issue.
\end{abstract}

Keywords: ASIER, Ibero-American Space, History of Reception, Paul Ricœur 


\section{Coordenadores}

Gonçalo Marcelo é licenciado em Filosofia e doutorado em Filosofia Moral e Política pela Universidade Nova de Lisboa. Atualmente, é bolseiro de pós-doutoramento (SFRH/BPD/102949/2014) da FCT, desenvolvendo o seu projeto como membro do $\mathrm{CECH}$ (Universidade de Coimbra) e em parceria com a Departamento de Filosofia da Universidade de Columbia, sendo igualmente professor convidado na Católica Porto Business School.

César Correa Arias é doutorado em Ciências da Educação pela Universidad de Guadalajara / Université de Toulouse e pós-doutorado em Políticas do Ensino Superior pela EHESS (Paris). Atualmente, é Professor na Universidad de Guadalajara, Professor Associado do Seminário Regular Permanente sobre Políticas do Ensino Superior na EHESS (Paris) e membro do Sistema Nacional de Investigadores, financiado pelo CONACYT (México).

Patrícia Lavelle é mestrada em História Social da Cultura pela PUC-Rio e doutorada em Filosofia e Ciências Sociais pela EHESS (Paris), tendo desenvolvido pesquisa de pós-doutorado no Walter Benjamin-Archiv (Berlim) e no Fonds Ricœur (Paris). Atualmente é Professora na PUC-Rio e investigadora do Centre Georg Simmel (EHESS) e do Fonds Ricour.

Tomás Domingo Moratalla é doutorado em Filosofia pela Universidad Pontificia Comillas. Atualmente, é Professor de Filosofia Moral na Faculdade de Filosofia da Universidad Complutense de Madrid. É igualmente correspondente do Fonds Ricœur em Espanha e Vice-Presidente da Associação Ibero-Americana de Estudos Ricœurianos (ASIER). 


\section{Editors}

Gonçalo Marcelo holds a degree in Philosophy and a PhD in Moral and Political Philosophy from Universidade Nova de Lisboa. Currently he is a Postdoctoral researcher, recipient of a FCT grant (SFRH/ BPD/102949/2014), developing his project at CECH (Universidade de Coimbra) in partnership with the Department of Philosophy of Columbia University in the City of New York, and he is also an invited Lecturer at Católica Porto Business School.

César Correa Arias holds a PhD in Education Sciences from Universidad de Guadalajara / Université de Toulouse and a Postdoctoral degree in Higher Education Policies from EHESS (Paris). Currently he is a Professor at Universidad de Guadalajara, Associate Professor of the Seminar on Higher Education Policies at EHESS (Paris) and a member of the Mexican National System of Researchers, funded by the CONACYT.

Patrícia Lavelle holds a master's degree in Social History of Culture from PUC-Rio and a PhD in Philosophy and Social Sciences from EHESS (Paris) and she conducted Postdoctoral research at the Walter Benjamin-Archiv (Berlin) and at the Ricour (Paris). Currently she is a Professor at PUC-Rio and researcher at Centre Georg Simmel (EHESS) and the Fonds Ricœur.

Tomás Domingo Moratalla holds a $\mathrm{PhD}$ in Philosophy from Universidad Pontificia Comillas. Currently he is a Professor of Moral Philosophy in the Faculty of Philosophy of Universidad Complutense de Madrid. He is also a correspondent of the Fonds Ricour in Spain and the Vice-President of the Asociación Ibero-Americana de Estudios Ricourianos (ASIER). 


\section{S U M Á R I O}

Parte I: Dossier Temático - A Atualidade de Paul Ricœur numa Perspetiva Ibero-Americana

(Part I: Thematic Issue - Paul Ricœur's Timeliness from an Ibero-American Perspective)

Introdução

(Introduction)

Gonçalo Marcelo, César Correa Arias, Patrícia Lavelle, Tomás Domingo Moratalla....

La hermenéutica en España: la recepción de la obra y pensamiento de Paul Ricœur (Hermeneutics in Spain: the reception of Paul Ricœur's thinking and works)

Francisco José García Lozano 45

A receção do pensamento histórico de Ricœur na historiografia portuguesa: Fátima Bonifácio e Fernando Catroga

(The reception of Ricœur's historical thought in Portuguese historiography: Fátima Bonifácio and Fernando Catroga) 
La víctima como sujeto capaz. A propósito del conflicto colombiano (The Victim as a capable subject. Notes on the Colombian conflict) Manuel Prada Londoño

Los límites del perdón ricœuriano desde la perspectiva argentina (The limits of Ricour's concept of forgiveness from an Argentinian perspective)

Esteban Lythgoe 145

Temporalidad, acontecimiento y poder

(Temporality, event and power)

Aníbal Fornari

Testemunhos

(Testimonies)

Sobre a recepção da filosofia de Paul Ricœur no Brasil

(On the reception of Paul Ricœur's philosophy in Brazil)

Testemunho de Jeanne Marie Gagnebin recolhido

por Patrícia Lavelle

(A Testimony of Jeanne Marie Gagnebin collected by Patrícia Lavelle).

Qual o legado principal de Paul Ricœur à Filosofia Contemporânea? (What is Paul Ricour's main legacy to contemporary philosophy?) Testemunho de Hilton Japiassu recolhido por Claudio Reichert do Nascimento

(A Testimony of Hilton Japiassu collected by Claudio Reichert do Nascimento) 
Parte II: Varia

(Part II: Varia)

Esboço para uma dimensão estética em Paul Ricœur

(Outlines of an aesthetic dimension in Paul Ricœur)

Vinicius Oliveira Sanfelice.

243

Reseña (Book Review) de Tomás Domingo Moratalla, Agustín Domingo Moratalla (ed.), Bioética y bermenéutica.

La ética deliberativa de Paul Ricour

Marcos Alonso Fernández. 267 



\section{PA R T E I}

DOSSIER TEMÁTICO - A ATUALIDADE DE PAUL RICGUR NUMA PERSPETIVA I B E R O - A M E R I C A N A

$$
\boldsymbol{P A R T} I
$$

THEMATIC ISSUE - PAUL RICEUR'S TIMELINESS FROM AN IBERO-AMERICAN PER SPECTIVE 



\title{
I NT R O D U Ç Ã O
}

\author{
INTRODUCTION
}

\section{A Atualidade de paul Ricoen}

\author{
NUMA PERSPETIVA IBERO-AMERICANA ${ }^{1}$ \\ PAUL RICAEUR'S TIMELINESS \\ FROM AN IBERO-AMERICAN PERSPECTIVE
}

\footnotetext{
${ }^{1}$ Esta introdução e os dados que nela vêm relatados teriam sido impossíveis de escrever sem um esforço colaborativo que envolveu várias pessoas de diferentes países. Os editores gostariam de agradecer em especial a Fernando Nascimento, María Luján Ferrari e Patrício Mena Malet pela ajuda na colheita de dados relevantes para traçar este panorama do espaço ibero-americano. Quaisquer imperfeições ou omissões que possam ser apontadas, e que serão aliás inevitáveis num esforço parcelar e introdutório, são obviamente da nossa inteira responsabilidade. O agradecimento é obviamente extensível à Imprensa da Universidade de Coimbra, nomeadamente na pessoa do seu diretor, Delfim Ferreira Leão, pelo apoio ao projeto desta série e pela disponibilidade em acolhê-la, bem como a Maria Luísa Portocarrero, principal impulsionadora das atividades dedicadas a Ricour em Coimbra. O agradecimento estende-se igualmente ao Comité Editorial do Fonds Ricœur pela autorização dada para que o projeto viesse a lume e utilizasse o presente nome. Estamos especialmente gratos a Jean-Paul Ricœur, presidente do referido comité, bem como a Olivier Abel, Johann Michel e Michaël Foessel, que colaboram desde há muito com as atividades da ASIER e sempre encorajaram e apoiaram este projeto. Finalmente, agradecemos também a todos os membros da ASIER, aos revisores que anonimamente ajudaram a selecionar e melhorar os capítulos e aos autores publicados neste volume, pela paciência com que aguardaram pela publicação deste número que, embora tenha sofrido alguns percalços ao longo do tempo que atrasaram a sua data de publicação original, nem por isso deixou de ser o primeiro tijolo, a obra inaugural de uma atividade que esperamos profícua no futuro, contribuindo para a expansão da ASIER e dos estudos ricœurianos no espaço ibero-americano.
} 
Gonçalo Marcelo

Universidade de Coimbra/Católica Porto Business School ${ }^{2}$

César Correa Arias

Universidad de Guadalajara ${ }^{3}$

Patrícia Lavelle

PUC Rio ${ }^{4}$

Tomás Domingo Moratalla

Universidad Complutense de Madrid $^{5}$

O presente volume inaugural da Ricœuriana - Associação Ibero-Americana de Estudos Ricourianos assinala o início de uma nova fase nos estudos ricœurianos, sobretudo no espaço ibero-americano. A ligação de Ricœur à região é antiga, tendo o filósofo feito visitas regulares quer à Península Ibérica, quer à América Latina. De igual forma, a influência exercida por ele e, de forma mais lata, pela sua obra em toda a sua autonomia semântica, no espaço ibero-americano, tem vindo a crescer ao longo das últimas décadas.

Se, por um lado, Ricour assinalou de forma exemplar a sua presença quer na filosofia, quer no espaço público, ao longo de quase 70 anos de intervenções e publicações regulares (publicou de 1935 a 2004!) e se o reconhecimento público da sua grandeza e genialidade foi crescente, a verdade é que, ao longo da sua vida,

${ }^{2}$ Gonçalo Marcelo, Centro de Estudos Clássicos e Humanísticos, Faculdade de Letras, Instituto de Estudos Clássicos, Largo da Porta Férrea, 3004-530 Coimbra, Portugal / Universidade Católica Portuguesa, Católica Porto Business School, Rua Diogo Botelho 1327, 4169-005, Porto, Portugal. E-mail: goncalomarcelo@gmail.com

3 César Correa Arias, Departamento de Ciencias Sociales y Jurídicas, CUCEA, Universidad de Guadalajara, Periférico Norte \# 799, Núcleo Los Belenes. C. P. 45100. Zapopan, Jalisco, México. E-mail: cesarca@hotmail.com

${ }^{4}$ Patrícia Lavelle, PUC-RJ, Departamento de Letras, Rua Marquês de São Vicente, 225, Gávea Rio de Janeiro, CEP: 22430-060 Brasil. E-mail: patricia.g.lavelle@gmail.com

5 Tomás Domingo Moratalla, Departamento de Historia de la Filosofía, Estética y Filosofía Moral, Facultad de Filosofía, Universidad Complutense de Madrid, Ciudad Universitaria, 28040, Madrid, España. E-mail: tomasdom@ucm.es 
a receção da sua obra sofreu um pouco em virtude de o seu autor ser um constante desalinhado, cristão de esquerda, sem escola oficial de seguidores e sem pretender constituí-la mas, por outro lado... com um pensamento de tal forma aberto, plural, acolhedor e heterodoxo que foi conseguindo paulatinamente granjear simpatias em diversos pontos do mundo entre especialistas de diferentes áreas. E esse reconhecimento tornou-se praticamente consensual, aumentando exponencialmente depois da sua morte em 2005. Por entre a multiplicação de encontros científicos, publicações e outras homenagens surgiu, de forma ainda informal, a ASIER (Associação Ibero-Americana de Estudos Ricœurianos) em 2010.

Tendo organizado Congressos em Guadalajara (2010), Rio de Janeiro (2011), Santiago do Chile (2013), La Plata (2015) e em São Leopoldo (2017), esta associação que federa os diversos estudiosos do pensamento de Paul Ricœur no espaço ibero-americano e organiza atividades em rede, prepara-se para organizar o seu sexto congresso, na Colômbia, em 2019. Paralelamente, o número cada vez maior de investigações sobre Paul Ricœur em português e espanhol, e a maturidade que a área dos estudos ricourianos já atingiu ao longo dos últimos anos, justificam o aparecimento da presente série. A Ricouriana, fiel ao pensamento de Ricœur, constitui-se como uma série de livros de publicação em acesso livre, dedicada à obra do autor que lhe dá o nome mas, ao mesmo tempo, aberta a contribuições que também versem sobre outros autores e áreas, fomentando um permanente espírito de diálogo e interdisciplinaridade.

Como expressão de um dos traços característicos desta série, a equipa editorial decidiu consagrar o dossier principal deste volume inaugural à atualidade de Paul Ricour numa perspetiva ibero-americana. Por "perspetiva ibero-americana" entendemos simultaneamente um diagnóstico da influência que Ricœur de facto tem no panorama intelectual de diferentes países ibero-americanos e as múltiplas intersecções que podem ser feitas entre a sua obra e 
questões especificamente ibero-americanas. Imediatamente a seguir ao dossier temático encontrar-se-á uma secção de varia, com um capítulo e uma recensão dedicados a aspetos do pensamento de Ricœur não diretamente ligados com o tema do dossier. Passemos então a uma breve contextualização e apresentação do conteúdo deste número inaugural.

Assinale-se, em primeiro lugar, que este trabalho não é, nem nunca poderia ser, exaustivo. Outros trabalhos, localizados e específicos, sobre a receção de Ricœur em diferentes contextos do espaço ibero-americano foram publicados anteriormente ${ }^{6}$ e não existe nenhum estudo aprofundado e exaustivo sobre este tema. Considere-se este dossier temático como um contributo para começar a construir de forma integrada esse esforço de mapeamento do pensamento de Ricœur; esforço que, decerto, continuará no futuro, não sendo de excluir a possibilidade de virmos a dedicar mais dossiers a este assunto.

Importa, em primeiro lugar, referir a questão das línguas em que Ricour é publicado, ainda para mais quando nos debruçamos sobre o trabalho de um filósofo para quem a hospitalidade linguística foi tão importante. Falar da presença de Ricœur no espaço ibero-americano confunde-se, até certo ponto, com a história da sua receção em português e espanhol. É evidente que o espaço ibero-americano e estas duas línguas não são co-extensivos - relembremos o óbvio: ambas as línguas são faladas em muitos outros pontos do mundo e, por outro

\footnotetext{
${ }^{6}$ Veja-se, por exemplo, Ricœur em Coimbra: receção filosófica da sua obra, editado por Maria Luísa Portocarrero e José Beato (Coimbra: Imprensa da Universidade de Coimbra, 2016), sobretudo o capítulo de Marcelino Agís Villaverde, "La Huella de Paul Ricour en la Península Ibérica",13-41; e igualmente A Filosofia de Paul Ricœur, editado por Fernanda Henriques (Coimbra: Ariadne, 2006), sobretudo a secção "Paul Ricœur em língua portuguesa" (477-484), preparada por Margarida I. Almeida Amoedo e Ana Carina Vilares, e que faz uma recolha, atualizada até novembro de 2005, da bibliografia primária e secundária de Paul Ricœur. Para um levantamento mais aturado, em português, espanhol, e outras línguas, poder-se-á consultar a clássica bibliografia de Frans D. Vansina, Paul Ricoeur Bibliography 1935-2008 (Leuven: Peeters, 2008), atualizada até 2008 e, para toda a bibliografia posterior, a página do Fonds Ricœur: www.fondsricoeur.fr
} 
lado, elas não esgotam, de forma alguma, a diversidade linguística que povoa este espaço - mas não nos parece descabido conjeturar que a esmagadora maioria da receção da obra deste filósofo se tenha feito, nos países ibero-americanos, através da publicação das suas obras em português e espanhol (apesar da presença sempre óbvia de um público francófilo mais cultivado que sempre as terá lido no original, em francês, bem como de um conjunto de especialistas da obra que, mesmo trabalhando em território ibero-americano, publicam frequentemente estudos sobre Ricœur noutras línguas, sobretudo em francês ou inglês). E, em relação a este panorama, importa recordar que as primeiras traduções dos livros de Ricœur em português e espanhol datam de finais dos anos 60. Em 1968 é publicado, no Brasil, História e Verdade ${ }^{7}$ decorrendo depois quase uma década até que outros livros fossem traduzidos: Da Interpretação ${ }^{8}$, O Conflito das Interpretações ${ }^{9}$ e Interpretação e Ideologias. ${ }^{10} \mathrm{Em}$ Portugal, as traduções e a força da receção de Ricœur começaram mais tarde, tendo a década de 80 assistido não só ao seu início como a um enorme aumento do interesse pelas suas obras num curto espaço de tempo, com a publicação de $A$ Metáfora Viva, ${ }^{11}$ Teoria da Interpretação ${ }^{12}$

\footnotetext{
${ }^{7}$ Ricœur, História e Verdade, tradução de F. A. Ribeiro (Rio de Janeiro: Forense, 1968).

8 Ricœur, Da Interpretação: ensaio sobre Freud, tradução de H. Japiassu (Rio de Janeiro: Imago, 1977).

9 Ricœur, O Conflito das Interpretações: ensaios de hermenêutica, tradução e apresentação de H. Japiassu (Rio de Janeiro: Imago, 1978)

10 Ricœur, Interpretação e Ideologias, tradução e apresentação de H. Japiassu (Rio de Janeiro: Francisco Alves, 1978).

${ }^{11}$ Ricœur, A Metáfora Viva, tradução de J. Torres Costa e A. M. Magalhães, com introdução de M. B. Pereira (Porto: Rés, 1983).

12 Ricœur, Teoria da Interpretação. O discurso e o excesso de significação, tradução de A. Morão (Lisboa: Edições 70, 1987).
} 
e O Discurso da Acção. ${ }^{13}$ Em Espanha, Finitud y culpabilidad ${ }^{14}$ é publicado em 1969, seguindo-se-lhe, em 1970, no México, a publicação de Freud: una interpretación de la cultura. ${ }^{15}$ No decurso dos anos 70, a obra de Ricoeur começa a ser publicada a bom ritmo na Argentina, com diversas traduções parciais de $O$ Conflito das Interpretações e, em 1977, a publicação de La Metáfora Viva. ${ }^{16}$

No que diz respeito a esta receção da obra de Ricœur em português e espanhol, se medida pelas traduções dos seus livros em ambas as línguas, é importante assinalar que elas se multiplicam de forma exponencial ao longo das décadas seguintes, sobretudo impulsionadas pelo grande sucesso, em França e um pouco por todo o mundo, dos livros mais relevantes: Tempo e Narrativa ${ }^{17}$ na década de $80, O$ Si-mesmo Como um Outro ${ }^{18}$ no início da década de 90 e A Memória, a História, o Esquecimento ${ }^{19}$ em 2000. O carácter marcante de cada um destes livros, em diferentes áreas disciplinares (da teoria literária à historiografia, passando, obviamente, pela filosofia) serviu certamente para popularizar o nome do filósofo e atrair o interesse de cada vez mais leitores à sua obra e incentivar editoras por todo o mundo (inclusive, obviamente, no espaço ibero-americano) a pu-

13 Ricœur, O Discurso da Acção, tradução de A. Morão (Lisboa: Edições 70, 1988). Republicado, com revisão, introdução e notas de Gonçalo Marcelo: O Discurso da Ação (Lisboa: Edições 70, 2013).

14 Ricœur, Finitud y Culpabilidad, tradução de C. Sánchez Gil com introdução de J. L. L. Aranguren (Madrid: Taurus, 1969).

15 Ricœur, Freud: una interpretación de la cultura, tradução de A. Suárez, M. Olivera e E. Inciarte (México: Siglo XXI, 1970).

16 Ricœur, La Metáfora Viva, tradução de G. Baravalle (Buenos Aires: La Aurora, 1977).

${ }^{17}$ Ricœur, Tempo e Narrativa. Tomo I, tradução de C. Marcondes César (Campinas: Papirus, 1994); Tempo e Narrativa. Tomo II, tradução de M. Appenzeller, com revisão de M. Villela-Petit (Campinas: Papirus, 1995); Tempo e Narrativa. Tomo III, tradução de R. Leal Ferreira, com revisão de M. Villela-Petit (Campinas: Papirus, 1996).

18 Ricœur, O Si-mesmo Como um Outro, tradução de L. Moreira César (Campinas: Papirus, 1991).

19 Ricour, A Memória, a História, o Esquecimento, tradução de A. François et. al. (Campinas: UNICAMP, 2007). 
blicar não só as traduções destes livros mas também a ir recuperar, traduzindo-os, livros anteriores que, por vezes, tinham tido tendência a ter uma receção mais modesta e quase caído no esquecimento ${ }^{20}$. E este movimento acelerou, reiteramo-lo, após a morte de Ricœur e a profusão de homenagens e estudos em seu torno. Hoje em dia, a esmagadora maioria dos livros de Ricœur está traduzida em português e espanhol sendo que as novas publicações póstumas (como é o caso dos Escritos e Conferências ${ }^{21}$ ) são muitas vezes rapidamente traduzidas e publicadas em diferentes línguas.

Porém, como é evidente, nem só de traduções se tem feito a receção de Ricœur. E muitos têm sido, portanto, os autores que, no espaço ibero-americano, contribuíram não só para a difusão da obra de Ricœur mas também construíram pensamentos sólidos e originais inspirados por ele. Em muitos dos países ibero-americanos a influência é antiga e muito beneficiou de contactos pessoais de alguns pensadores que se tornaram bastante próximos de Ricœur. Isto não significa, é claro, e como já referimos, que qualquer "escola" se tenha constituído em torno dele. Porém, não é possível ignorar, numa história da receção do filósofo, as múltiplas pessoas que, ou por via de relações pessoais desenvolvidas com Ricœur ou pelo encontro propriamente intelectual com a sua obra, depois contribuíram para a difusão do seu pensamento, fosse na forma de traduções, de ensino e orientação de teses, da organização de eventos académicos (em que o filósofo por vezes marcava presença) ou na publicação de bibliografia secundária relevante. A receção do pensamento de Ricœur

\footnotetext{
20 Veja-se, por exemplo, Ricœur, A Simbólica do Mal, tradução de H. Barros e G. Marcelo (Lisboa: Edições 70, 2013).

21 Ricœur, Escritos e Conferências 1: em torno da psicanálise, tradução de E. Bini (São Paulo: Loyola, 2010); Escritos e Conferências 2: hermenêutica, tradução de L. Pereira de Souza (São Paulo: Loyola, 2011); Escritos e Conferências 3: antropologia filosófica, tradução de L. Christina de Malimpensa (São Paulo, Loyola, 2016); Escritos y Conferencias 1: alrededor del psicoanálisis, tradução de A. Castañon (México: Siglo XXI, 2009); Escritos y Conferencias 2: hermenéutica (México: Siglo XXI, 2013).
} 
fez-se, por conseguinte, de todos estes encontros e produzindo todos estes resultados. Não podendo ignorar esta marca relevante deixada por inúmeros estudiosos e próximos de Paul Ricour, também nos seria impossível, no exíguo espaço desta introdução, fazer um levantamento pormenorizado de todos aqueles que desempenharam um papel relevante ao longo dos já quase 50 anos de receção significativa desta obra no espaço ibero-americano. Ainda assim, e sob a forma de uma mera descrição de alguns dos momentos históricos, estudiosos pioneiros e tendências gerais da receção de Ricœur neste espaço (incluindo, de forma muito circunscrita, alguma investigação recente), aventurar-nos-emos a assinalar, nesta introdução, alguns dos seus protagonistas principais.

Fará talvez sentido, pela força que a presença do pensamento de Ricœur aí assume, começar com uma descrição da receção no Brasil. Neste país, para além do trabalho pioneiro de tradução e divulgação levado a cabo por Hilton Japiassu, é importante mencionar a influência de Maria da Penha Villela-Petit, ${ }^{22}$ filósofa brasileira radicada em França e que, desde meados dos anos 60, assistia aos seminários de Ricœur na Sorbonne e em Nanterre, tendo depois participado no seminário da Rue Parmentier, no Colóquio de Cerisy dedicado a Ricœur no final dos anos 80 e, para além de ter revisto algumas das traduções preexistentes no Brasil, foi também uma das grandes divulgadoras do seu pensamento. ${ }^{23}$ Num país onde o número de produções académicas (livros, artigos, teses) sobre a obra de Ricœur é enorme, destaquem-se ainda, pela sua influência, os trabalhos de

\footnotetext{
22 Veja-se, a propósito da ligação de Maria da Penha Villela-Petit a Ricoeur, François Dosse, Paul Ricour, les sens d'une vie (Paris: La Découverte, 2008), 427, 429, 519.

23 Veja-se, por exemplo, Maria Villela-Petit, "Paul Ricœur: D'Histoire et vérité à Temps et récit: la question de l'histoire" in Paul Ricour. Les métamorphoses de la raison herméneutique. Actes du Colloque de Cerisy-la-Salle 1988, editado por Jean Greisch e R. Kearney (Paris: Cerf, 1991),186-197; "Le Sujet multiple et le soi - Le "je suis plusieurs" de Fernando Pessoa", Études de Lettres, no 3-4 1(996): 109-124; "Perspectiva Ética e Busca do Sentido em Paul Ricœur", in Síntese - Rev. de Filosofia v. 34 n. $^{\circ} 108$ (2007): 5-22.
} 
Constança Marcondes César ${ }^{24}$ e Jeanne Marie Gagnebin²5, filósofa suíça residente no Brasil desde finais dos anos 70, e cujo trabalho incide tanto nos estudos literários quanto na filosofia. Merece igualmente destaque a área dos estudos literários, nos quais a presença da hermenêutica ricœuriana é inegável. De facto, a receção de Ricœur no Brasil tem sido muito forte não só na filosofia, como também no campo dos estudos literários. Há, neste país, um interesse considerável pelos objetos teóricos que marcaram a sua obra a partir dos anos 70 e que assumem relevância considerável no vasto e polimorfo campo literário. Assim, a sua obra é relevante não só nos departamentos de filosofia, mas também nos de letras. A este respeito, cabe sublinhar o papel de Jeanne Marie Gagnebin, cujos trabalhos contribuíram significativamente para a receção de Ricour em ambas as áreas uma vez eles abordam temas literário-filosóficos, como a narrativa e a metáfora e contribuem para pensar a relação entre a literatura e a filosofia a partir da obra ricouriana. Nos dias de hoje, como os dados quantitativos que citamos abaixo comprovam, a presença da filosofia ricouriana no Brasil é extremamente forte, com um grande conjunto de professores e jovens investigadores a renovar e continuar o esforço de receção. ${ }^{26}$

24 Veja-se A Hermenêutica Francesa: Paul Ricœur, editado por Constança Marcondes César (Porto Alegre: EDIPUCRS, 2002); Constança Marcondes César, Crise e Liberdade em Merleau-Ponty e Ricoeur (Aparecida-SP: Idéias e Letras, 2011).

25 Veja-se, nomeadamente: Jeanne Marie Gagnebin, "Uma filosofia do cogito ferido: Paul Ricœur", in Estudos Avançados v. 30 (1997): 261-272; "Les préludes de Paul Ricœur, in La juste mémoire, editado por Olivier Abel et. al. (Geneva: Labor et Fides, 2006), 169-181; "Da dignidade ontológica da literatura", in Paul Ricour: ética, identidade e reconhecimento, editado por Fernando Nascimento e Walter Salles (São Paulo: Loyola, 2013), 37-56. E veja-se igualmente o testemunho recolhido por Patrícia Lavelle e que publicamos no final deste dossier temático.

26 Para além dos nomes pioneiros já referidos, mencionem-se ainda, a título de mero exemplo, os trabalhos de Patrícia Lavelle, "Prefácio" e tradução de Paul Ricœur, Sobre a Tradução (Belo Horizonte: UFMG, 2011); Roberto Roque Lauxen, "Interfaces e Distanciamentos entre a Hermenêutica de Hans-Georg Gadamer e Paul Ricœur" in Philósophos - Revista de Filosofia v. 17, n. ${ }^{\circ} 1$ (setembro 2011): 127 -158; Fernando Nascimento e Walter Salles (eds.), Paul Ricœur-Ética, Identidade 
Já em Portugal a influência também é antiga e presente em múltiplos polos universitários, sendo a influência do pensamento ricoeuriano talvez mais patente em Lisboa, Coimbra e Évora. Em Lisboa, o filósofo belga Michel Renaud, antigo aluno de Ricœur desde os tempos da sua presença em Lovaina no início dos anos 70 , iniciou vários alunos e investigadores ao pensamento de Ricœur na Universidade Nova de Lisboa, o mesmo podendo ser dito de Joaquim Cerqueira Gonçalves na Universidade de Lisboa, de Joaquim de Sousa Teixeira na Universidade Católica Portuguesa, e de Miguel Baptista Pereira na Universidade de Coimbra, tendo o trabalho pioneiro de cada um destes autores contribuído igualmente para criar um espaço de difusão e debate sobre o pensamento ricœuriano em Portugal ${ }^{27}$. São igualmente de mencionar os múltiplos trabalhos e o esforço de formação nos estudos ricœurianos levados a cabo em Coimbra por Maria Luísa Portocarrero ${ }^{28}$, em Évora por Fernanda Henriques ${ }^{29}$

e Reconhecimento (São Paulo: Loyola, 2013); Elsio José Corá e Claudio Reichert do Nascimento, "Reconhecimento em Paul Ricœur: da identificação ao reconhecimento mútuo" in Revista de Ciências Humanas v. 45, n. ${ }^{\circ} 2$ (2012): 407-423; Adriane da Silva Machado Möbbs, "A importância do símbolo na obra de Paul Ricœur" in Peri, v. 6 (2014): 1-27; e Weiny César Freitas Pinto, "Ricœur, leitor de Freud: notas sobre a questão do sujeito em Freud" in Peri, vol. 7 (2015): 87-105.

27 Veja-se, a título de exemplo: Michel Renaud, "Fenomenologia e hermenêutica. O projecto filosófico de Paul Ricœur", in Revista Portuguesa de Filosofia Tomo XLI, fasc. 4 (1985): 403-442; Michel Renaud, "O discurso filosófico e a unidade da verdade nas primeiras obras de Ricœur", in Revista Portuguesa de Filosofia, Tomo XLVI, fasc. 1 (1990): 19-48; Joaquim Cerqueira Gonçalves, "O que devemos e gostaríamos de dever a Paul Ricœur" in A Filosofia de Paul Ricœur, 45-47; Joaquim de Sousa Teixeira, Ipseidade e Alteridade: uma leitura da obra de Paul Ricœur (Lisboa: INCM, 2004); Joaquim de Sousa Teixeira, "Paul Ricœur e a problemática do mal", Didaskalia, Tomo VII, 1 (1977): 43-129; Miguel Baptista Pereira, "A Hermenêutica da Condição Humana de Paul Ricœur" in Revista Filosófica de Coimbra n. 24 (2003): 235-277.

${ }^{28}$ Veja-se Maria Luísa Portocarrero, A Hermenêutica do Conflito em Paul Ricour (Coimbra: Minerva, 1992); Horizontes da Hermenêutica em Paul Ricœur (Coimbra: Ariadne, 2005); Ricœur em Coimbra: receção filosófica da sua obra, op. cit.

29 Veja-se Fernanda Henriques, Filosofia e Literatura. Um percurso hermenêutico com Paul Ricour (Porto: Afrontamento, 2005); Paul Ricoeur e a Simbólica do Mal, editado por Fernanda Henriques (Porto: Afrontamento, 2005); Feminist Explorations of Paul Ricour's Philosophy, editado por Annemie Halsema e Fernanda Henriques (Lanham: Lexington Books, 2016). 
e em Lisboa por Carlos João Correia ${ }^{30}$ e Paula Ponce de Leão ${ }^{31}$ e que contribuíram, cada um à sua maneira, para a vitalidade deste pensamento em Portugal - não esquecendo igualmente a presença histórica dos estudos ricœurianos noutros pontos do país, como atestam as obras de Maria José Cantista ${ }^{32}$ (Porto), Manuel Sumares ${ }^{33}$ (Braga) ou Maria Gabriela Castro ${ }^{34}$ (Açores). Hoje em dia, podem talvez assinalar-se dois ou três grandes polos de interesse em torno do pensamento ricouriano neste país, sendo de assinalar a vitalidade dos estudos de hermenêutica ricœuriana ${ }^{35}$, sobretudo em Coimbra, através da linha de investigação "A Racionalidade Hermenêutica", dirigida por Maria Luísa Portocarrero, e a original ligação entre Ricœur e os estudos feministas ${ }^{36}$, promovida em Évora por Fernanda

30 Carlos João Correia, Ricour e a expressão simbólica do sentido (Lisboa: Gulbenkian, 1999); "Ricœur e a Metáfora Integral", in Revista da Faculdade de Letras n. ${ }^{\circ}$ 6-5. ${ }^{a}$ série (1986): 35-48.

31 Paul Ricœur. Uma homenagem, editado por Paula Ponce de Leão e A. Melo (Lisboa: ISPA, 2002); Paula Ponce de Leão, "Figuração e Sentido: da narratividade à ética na reflexão de Paul Ricœur" in $A A V V$, Poiética do mundo. Homenagem a Joaquim Cerqueira Gonçalves (Lisboa: Colibri, 2001), 503-517.

32 Maria José Cantista, "O Juízo Político de Hannah Arendt, segundo Paul Ricœur" in Revista da Faculdade de Letras da Universidade do Porto vol. 23-24 (2006-2007): 155-162.

33 Manuel Sumares, O Sujeito e a Cultura na Filosofia de Paul Ricoeur: para além da necessidade (Braga: Escher, 1989); Quando ser sujeito não é sujeitar-se e outros ensaios (Coimbra: Angelus Novus, 1993).

34 Maria Gabriela Azevedo e Castro, A Imaginação em Paul Ricœur (Lisboa: Instituto Piaget, 2002).

35 Maria Luísa Portocarrero, A Hermenêutica do Conflito em Paul Ricœur, op. cit.; Horizontes da Hermenêtica em Paul Ricour, op. cit; Hermeneutic Rationality/ La rationalité herméneutique, editado por A. Wiercinski, M. L. Portocarrero e Luís Umbelino (Münster: LIT Verlag, 2012); Maria Luísa Portocarrero, Hermenêutica Filosófica. Metodologia e apresentação de um percurso temático (Coimbra: Imprensa da Universidade de Coimbra, 2015); Luís Umbelino, "On the Ricoeurian Project of a Hermeneutics of Space" in Hermeneutics - Ethics - Education, editado por Andrzej Wiercinski (Zurich: LIT Verlag, 2015), 199-206.

36 Fernanda Henriques, "As teias da Razão: a racionalidade hermenêutica e o feminismo" in As Teias que as Mulberes Tecem (Lisboa: Colibri, 2003), 149-160; "Subsídios epistemológicos para pensar a temática do empowerment e da cidadania das mulheres. María Zambrano e Paul Ricœur" in Ex Aequo n. 7 (2002): 179-188; "The need for an Alternative Narrative to the History of Ideas or to Pay a Debt to Women; 
Henriques, sem esquecer a tradicional atenção prestada a temas como a história ${ }^{37}$, a ética e a bioética, ${ }^{38}$ a imaginação, ${ }^{39}$ a identidade pessoal $^{40}$ e o conflito. ${ }^{41}$ É igualmente de mencionar a centralidade do pensamento ricœuriano neste país, o que é comprovado, por exemplo, pela tarefa constante de tradução e introdução da obra do autor, com grande destaque para as edições 70 e, em anos recentes, sobretudo através dos esforços dos tradutores Hugo Barros e Gonçalo Marcelo ${ }^{42}$, e pelo próprio acolhimento desta série no seio da Imprensa da Universidade de Coimbra.

A Feminist Approach to Ricœur's Thought" in Études Ricœuriennes/ Ricœur Studies vol. 4, n. ${ }^{\circ} 1$ (2013): 7-20; Feminist Explorations of Paul Ricour's Philosophy, op. cit.

37 Martinho Soares, Tempo, Mythos e Praxis: o diálogo entre Ricœur, Agostinho e Aristóteles (Porto: Fundação Eng. António de Almeida, 2013); Martinho Soares, História e Ficção em Paul Ricour e Tucídides (Porto: Fundação Eng. António de Almeida, 2014).

38 Maria Luísa Portocarrero, "Experiência e Juízo nas Éticas Aplicadas: Fenomenologia Hermenêutica e Sabedoria Prática" in Revista Filosófica de Coimbra n. 41 (2012): 265-282; Michel Renaud, "Ética, Bioética e Investigação" in Ciclo de Conferências "ÁGORA - Ciência e Sociedade", 1-9, disponível on-line em https:// www.ulisboa.pt/wp-content/uploads/MRenaud_AGORA_Etica-Investigacao_23-01-2015. pdf; Maria Lucília Marcos, "Identidade Narrativa e Ética do Reconhecimento" in Études Ricœuriennes / Ricœur Studies vol. 2, n. ${ }^{\circ} 2$ (2011): 63-74; Maria João Coelho, "Corpo, Pessoa e Afectividade: da fenomenologia à bioética" (tese de mestrado, 1997), disponível em http://purl.pt/5485/1/sa-87495-v_PDF/sa-87495-v_PDF_X-C/ sa-87495-v_0000_1_tX-C.pdf.

39 Maria Gabriela Azevedo e Castro, A Imaginação em Paul Ricour, op. cit.

40 Joaquim de Sousa Teixeira, Ipseidade e Alteridade: uma leitura da obra de Paul Ricœur, op cit.; Sara Fernandes, "Ricœur e o problema da identidade pessoal" in A Filosofia de Paul Ricoeur, op. cit., 259-268; Carlos João Correia, "Notas para uma definição do conceito de ipseidade”, in A Filosofia de Paul Ricoeur, op. cit., 249-258.

${ }^{41}$ Maria Luísa Portocarrero, A Hermenêutica do Conflito em Paul Ricour, op. cit.; Fernanda Henriques, "A Esperança Escatológica e o Conflito de Interpretações" in A Filosofia de Paul Ricœur, op. cit., 109-114; Gonçalo Marcelo, "From Conflict to Conciliation and Back Again: some notes on Ricœur's dialectic" in Revista Filosófica de Coimbra n. ${ }^{\circ} 38$ (2010): 341-366; Gonçalo Marcelo, "The Conflict Between the Fundamental, the Universal and the Historical. Ricœur on Justice and Plurality", in Philosophy Today 58, 4 (2014): 645-664.

42 Veja-se Paul Ricœur, Vivo Até à Morte, seguido de Fragmentos, tradução de Hugo Barros e Gonçalo Marcelo (Lisboa: Edições 70, 2011); Paul Ricœur, A Simbólica do Mal, op. cit.; Paul Ricœur, O Discurso da Ação, op. cit.; e Paul Ricœur e Cornelius Castoriadis, Diálogo sobre a História e o Imaginário Social, tradução de Hugo Barros e Gonçalo Marcelo (Lisboa: Edições 70, 2016). 
Como prova da vitalidade dos estudos ricourianos em língua portuguesa, podem até citar-se alguns dados quantitativos, ainda que conservadores, para que se possa obter uma noção mais exata da penetração do pensamento do autor francês na língua de Fernando Pessoa e Drummond de Andrade. Uma colheita de dados on-line feita por Fernando Nascimento mostra que podem ser identificadas cerca de 250 publicações diretamente sobre Ricœur em português, publicadas entre 2010 e 2015. Uma pesquisa por áreas revela a ética como sendo a área mais representativa (com quase $23 \%$ de todas as publicações, seguida da hermenêutica (16\%), dos estudos literários / linguística, dos estudos na área do direito e da política, e da religião (contando cada uma destas rúbricas com um pouco mais de $10 \%$ de todas as publicações). Só no Brasil, desde 2000 podem ser encontrados dados sobre 26 teses de doutoramento e 32 dissertações de mestrado diretamente sobre Ricœur, o que mostra bem o interesse que o seu pensamento mobiliza. ${ }^{43}$

\footnotetext{
43 Sublinhe-se a natureza bastante conservadora dos dados apresentados. A metodologia adotada por Fernando Nascimento consistiu em procurar pelas publicações em português indexadas pelo Google Académico. Incluindo artigos e livros, a pesquisa só considerou as publicações que continham a palavra "Ricœur" no título, e o mesmo se aplicou às teses de doutoramento e dissertações de mestrado. Isto significa que o número potencial de artigos e livros sobre Ricœur em português é possivelmente bem maior. Em primeiro lugar porque, obviamente, nem tudo o que é publicado se encontra indexado e facilmente acessível através da internet, através do Google Académico ou outros instrumentos. E, em segundo lugar, porque não foram tomadas em conta as publicações que podem parcialmente incidir no trabalho de Ricœur mas nas quais, por algum motivo, os autores decidiram não incluir a palavra "Ricœur" no título, fazendo-o apenas nas palavras-chave ou nem sequer o destacando de todo nesses elementos. Para além disso, e como é óbvio, não foram consideradas as publicações da comunidade ricœuriana portuguesa ou brasileira noutras línguas, o que não é de somenos importância, dada a frequência com que vários académicos destes países publicam em francês ou inglês sobre a obra ricœuriana. Assim sendo, esta colheita de dados não dispensa a possibilidade de um trabalho mais vasto poder vir a ser desenvolvido no futuro mas, reiteramo-lo, mesmo nesta perspetiva extremamente conservadora, os resultados obtidos parecem-nos interessantes e promissores. No que diz respeito à taxonomia das áreas de publicação, ela foi desenvolvida por Nascimento a partir da leitura dos títulos e resumos das publicações encontradas. Em caso de sobreposição entre mais que uma categoria, o autor do estudo tentou discernir pelo contexto qual seria a categoria principal, nunca atribuindo mais que uma categoria a cada publicação. Os
} 
Em Espanha ${ }^{44}$, tal como em Portugal, a receção mais significativa da obra de Ricœur dá-se a partir dos anos 80, também beneficiando das deslocações frequentes que o autor começa a fazer à Península Ibérica (com maior frequência a Espanha) para participar em diversas atividades académicas, em sítios como a Universidade Complutense de Madrid, a Universidade Autónoma de Madrid, a Universidade de Santiago de Compostela e diversas universidades catalãs. ${ }^{45}$ A ligação de Ricœur a Espanha era forte, a ponto de, em novembro de 2003, já num estado de saúde bastante frágil, ter decidido fazer aquela que foi umas das suas últimas viagens de trabalho a Santiago de Compostela ${ }^{46}$, e da qual resultou um dos seus últimos textos importantes ${ }^{47}$, sobre o dom e o reconhecimento, pouco tempo antes de ser publicada a sua última obra, Percurso do Reconbecimento. ${ }^{48}$ Tal como noutros países, a forte ligação pessoal de Ricœur a al-

resultados detalhados foram os seguintes: Hermenêutica - 16,2\%; Religião - 10,3\%; Antropologia Filosófica - 9,6\%; Ética - 22,8\%; Direito/Política: 10,7\%; Literatura/ Linguística - 10,7\%; História - 7,7 \%; Psicanálise - 4\%; Educação - 2,5\%; Outros temas $-5,5 \%$. Esta recolha de dados foi levada a cabo para apresentação no painel "The Future of Ricœur Studies", organizado por George Taylor e inserido na 10th Annual Society for Ricœur Studies Fall Conference, tendo eles sido apresentados nesse painel por Gonçalo Marcelo. Agradecemos a Fernando Nascimento a gentileza de ter permitido a divulgação dos dados nesta introdução.

${ }^{4} 4$ Para uma apresentação mais detalhada da receção de Ricœur em Espanha, veja-se Marcelino Agís Villaverde, "Paul Ricœur en España" in Crisis de la Modernidad y Filosofías Ibéricas. Actas de las X Jornadas Internacionales del Hispanismo Filosófico (Madrid: Fundación Ignacio Larramendi - Universidad de Santiago de Compostela, 2013), 481-498, bem como Marcelino Agís Villaverde, "La Huella de Paul Ricœur en la Península Ibérica”, op. cit.

45 Marcelino Agís Villaverde, "La Huella de Paul Ricœur en la Península Ibérica", op. cit., p. 15.

46 A propósito desta deslocação a Santiago de Compostela, veja-se Marcelino Agís Villaverde, "La Huella de Paul Ricœur en la Península Ibérica", op. cit., 32-33.

${ }^{47}$ Ricœur, "La lutte pour la reconnaissance et l'économie du don" in Herméneutica y Responsabilidad. Homenaje a Paul Ricour, editado por Marcelino Agís Villaverde et. al., (Santiago de Compostela: Universidade de Santiago de Compostela, 2005), 17-28.

48 Ricœur, Percurso do Reconhecimento, tradução de N. N. Campanário (São Paulo: Loyola, 2006). 
guns académicos, como foi o caso de Marcelino Agís Villaverde ${ }^{49}$, facilitou a penetração e divulgação da obra em Espanha. Outro dos grandes divulgadores da filosofia de Ricœur neste país foi Manuel Maceiras ${ }^{50}$, que estudou com ele em Paris e foi outros dos grandes promotores das suas visitas a Espanha, tendo sido importante, num primeiro momento, para incentivar as traduções da sua obra para espanhol. Maceiras deu a conhecer o pensador francês, tanto pessoal como intelectualmente, a outras figuras que, mais tarde, viriam a impulsionar os estudos ricourianos em Espanha, como foi o caso do já mencionado Marcelino Agís Villaverde ou dos irmãos Tomás Domingo Moratalla51 e Agustín Domingo Moratalla que, hoje em dia, são dos principais impulsionadores e divulgadores da obra ricœuriana na península ibérica. Finalmente, entre as figuras pioneiras, mencione-se também Juan Masiá, 52 que conheceu Ricœur nas suas visitas ao Japão (nos anos 70 e 80) e que, assim, contribuiu para introduzir o pensamento ricœuriano tanto no Japão como em

49 Para além das obras já citadas, mencione-se também uma obra sua traduzida em português e com influência na receção de Ricœur em língua portuguesa: Marcelino Agís Villaverde, Paul Ricour: a força da razão compartida (Lisboa: Instituto Piaget, 2004).

50 De Manuel Maceiras podemos destacar os trabalhos, pioneiros no seu tempo, Introducción al personalismo actual (Madrid: Gredos, 1975) no qual propunha uma interpretação personalista e hermenêutica do pensador francês e La hermenêutica contemporânea (Madrid: Cincel, 1990), obra na qual Ricœur é apresentado, juntamente com Gadamer, como uma das grandes figuras da hermenêutica. Mencionem-se também as sugestivas e corretíssimas introduções que fez tanto a $L a$ metáfora viva quanto a Tiempo e narración. Veja-se Manuel Maceiras, "Presentación de la Edición Española" in Paul Ricœur, Tiempo y Narración I. Configuration del tiempo en el relato histórico (Buenos Aires: Siglo XXI Editores Argentina, 1995), 9-29.

51 Mencione-se, a título de exemplo do trabalho de divulgação levado a cabo pelos irmãos Moratalla, a coleção "Paul Ricœur" dirigida na editora Hermes: La ética hermenêtica de Paul Ricœur (Valencia: Hermes, 2013); Para leer a Paul Ricœur (Valencia: Hermes, 2013); Laicidad y pluralismo religioso (Valencia: Hermes, 2013) e Bioética e Hermenéutica. La ética deliberativa de Paul Ricour (Valencia: Hermes, 2013)

52 Por entre os múltiplos trabalhos de Juan Masiá, podem-se destacar aqueles que se encontram em Lecturas de Paul Ricour (Madrid: Universidad Comillas, 1998) livro que, para mais, incluía as contribuições de dois doutorandos: T. Domingo Moratalla e A. Ochaita Velilla). 
Espanha. Entretanto, a receção expandiu-se e foi contando com novos protagonistas. ${ }^{53}$ Uma apresentação mais sistemática da história desta receção específica pode ser encontrada no capítulo de Francisco José García Lozano, que mencionamos abaixo.

Na América Latina de expressão espanhola a situação é diversificada. Se existem alguns países nos quais a receção de Ricœur ainda tem um longo caminho a percorrer e, por isso, há que incentivar a sua expansão, existem outros nos quais a presença de Ricœur vem já de longa data e a sua receção é fecunda e profícua. Correndo embora o risco de deixar de fora desta breve recapitulação histórica alguns países e figuras importantes, não poderemos deixar de mencionar a situação na Argentina, no Chile e no México. Na Argentina $^{54}$ a receção da obra ricœuriana é tão antiga quanto o final dos anos 60/ princípio dos anos 70, e foi motivada pelo interesse, quer da filosofia, quer da literatura, por um pensamento que se afigurava ser uma alternativa válida ao neopositivismo. Um pouco mais tarde, com a publicação de La metáfora viva e Tiempo e narración, a obra de Ricœur começa a figurar nos planos de estudo de diversos cursos, sendo os cursos de História e Letras das Universidades de La Plata e de Buenos Aires bons exemplos. É igualmente de mencionar que Ricœur participou num colóquio na Facultad de Filosofía y Letras de la Universidad de Buenos Aires em 1983. Por entre as figuras

53 Para além da apresentação detalhada das muitas figuras ligadas à receção de Paul Ricœur em Espanha que pode ser lida no capítulo de García Lozano incluído neste volume, mencionem-se ainda, como exemplos da produtividade do trabalho sobre a obra ricœuriana entre os jovens investigadores espanhóis, as seguintes teses de doutoramento atualmente em curso: Andrea Fernández González, "Paul Ricœur: una aproximación a la problemática del concepto de persona y la cuestión de la identidad personal", desenvolvida nas universidades de Granada e Complutense de Madrid sob a direção de Tomás Domingo Moratalla; Christian Ruiz Rubio, "Técnica y responsabilidad. Posibilidades y límites de la hermenéutica dialógica de Gadamer y Ricœur", levada a cabo na Universidad de Valencia sob a direção de Agustín Domingo Moratalla.

54 Agradecemos a María Luján Ferrari pelas informações sobre a receção de Ricœur na Argentina e que constam neste parágrafo. 
importantes da receção e difusão do seu pensamento, há que referir que Mario Presas 55 (Univ. de La Plata), Roberto Walton ${ }^{56}$ (Univ. de Buenos Aires), Graciela Ralón de Walton ${ }^{57}$ (Univ. de San Martín), Rosa Belvedresi58 (Univ. de la Plata / Univ. de San Martín), Daniel Brauer59 (Univ. de Buenos Aires) e Francisco Naishtat ${ }^{60}$ (Univ. de Buenos Aires e La Plata) todos introduziram a obra de Ricœur nos programas que foram lecionando e portanto desempenharam um importante papel na formação de várias gerações de estudantes e na introdução ao pensamento ricœuriano. Tiveram igualmente um lugar de grande destaque na difusão do pensamento ricœuriano Marie-France Begué61, da Universidad del Salvador (Buenos Aires) e Aníbal Fornaría ${ }^{2}$, da Universidad Católica de Santa Fe, pelos inúmeros trabalhos que lhe dedicaram e pela intensa dedicação à sua

\footnotetext{
55 Veja-se por exemplo Mario Presas, "La lectura de Freud de Paul Ricœur" in Cuadernos de Filosofía vol. 44 (1998): 37-48.

56 Roberto Walton, "Husserl y Ricœur sobre la intersubjetividad y lo político" in Investigaciones Fenomenológicas, vol. 3 (2011): 35-60.

57 Graciela Ralón de Walton, "La posibilidad de la no-violencia y el carácter trágico de la acción histórica" in Devenires XVI, 31 (2015): 43-64.

58 Rosa Belvedresi, "Consideraciones acerca de la memoria, el olvido y el perdón a partir de los aportes de P. Ricœur" in Revista latinoamericana de filosofía vol. 23 (2006): 199 - 211

59 Daniel Brauer, "El yo ajeno a sí-mismo. Un estudio comparativo entre la noción de 'ipseidad' en Paul Ricœur y el concepto de autoconciencia en Hegel" in El retorno del Espíritu. Motivos hegelianos en la filosofía práctica contemporánea (ed. Miguel Giusti) (Lima: Pontificia Universidad Católica del Peru, 2003), 201-214.

${ }^{60}$ Francisco Naishtat, "Del Ipse existencial al Ipse narrativo. Fronteras y pasajes entre la fenomenología ontológica de Sartre y la fenomenología hermenéutica de Ricœur" in Revista de Filosofía y Teoría Política $\mathrm{n}^{\circ} 38$ (2007): 95-120. Mencione-se igualmente o seminário "Lecturas del último Ricœur: En torno a la noción de reconocimiento", animado por Naishtat em La Plata em 2006.

${ }^{61}$ Das numerosas publicações de Marie-France Begué sobre Ricœur, destaque-se a obra Paul Ricour: la poética del sí-mismo (Buenos Aires: Biblos, 2003). Veja-se igualmente o artigo "De la pulsión a la solicitud por el otro: bases antropológicas para la "pequeña ética de Ricœur" in Études Ricœuriennes/Ricour Studies vol. 2, n. ${ }^{\circ} 2$ (2011): 15-32.

62 Veja-se, para além do capítulo de Fornari no dossier temático desta revista, a obra Razón y Sentimiento: La formación de la consciencia de pertenencia en la antropología de Paul Ricœur (Roma: PUL-Edizioni, 1987).
} 
obra. No presente, novas gerações continuam a levar a cabo uma importante obra de difusão deste pensamento em diversas áreas. ${ }^{63}$

Também no Chile ${ }^{64}$ podemos encontrar um primeiro contacto com a pessoa e a obra de Ricœur a partir de meados dos anos 60. Mais exatamente, o primeiro encontro de que há registo data de 1965, altura em que Humberto Giannini, 65 filósofo chileno discípulo de Enrico Castelli, o conhece pessoalmente, por ocasião do Colóquio Castelli dedicado ao tema "Démythisation et morale". Giannini propõe-se então traduzir a conferência dada por Ricœur. Assim, a publicação de "Simbólica del mal y Reflexión" inaugura uma receção da obra ricœuriana no Chile, muito ligada às temáticas da Simbólica do Mal, receção que Giannini promove através da sua hermenêutica reflexiva e da sua antropologia da falibilidade. Esta pista é igualmente seguida por Cristóbal Holzapfel, ${ }^{66}$ da Universidade de Chile e Iván Trujillo Correa da Universidad Católica de Valparaíso. Este último animou, em meados dos anos 90, um seminário em Valparaíso, para o qual

63 Mencionem-se, a título de exemplo, as reflexões de Francisco Díez Fischer sobre a tradução in "La potencialidad de la traición hermenéutica" in Doletiana: revista de traducció, literatura $i$ art vol. 4 (2013): 1-10; o trabalho de Esteban Lytghoe que, para além do capítulo publicado no dossier temático do presente volume, anima o seminário de doutoramento "Representación e imaginación en la filosofía de la historia de Paul Ricœur" e publica regularmente sobre a questão da história - veja-se nomeadamente "El rol político del historiador en el último Ricœur y el papel de la imaginación productiva en su labor" in Astrolabio: revista internacional de filosofia 16 (2015): 26-40; e igualmente os trabalhos da nova geração, devendo ser assinaladas, como exemplos, a tese de doutoramento de Silvia Gabriel, Ricoeur y lo político (Buenos Aires: Prometeo, 2015) e as teses de licenciatura de Alejandra Bertucci: "Del símbolo al texto" (2003), María Luján Ferrari "El concepto de identidad narrativa según Paul Ricœur (2003)", e María Beatriz Delpech "Ricœur: el acontecimiento desde una perspectiva ontológica" (2013).

64 Agradecemos a Patricio Mena Malet pelas informações sobre a receção de Ricœur no Chile e que constam neste parágrafo.

65 Ricœur escreve o prefácio da tradução francesa da obra de Giannini, La reflexión cotidiana. Veja-se Humberto Giannini, La réflexion quotidienne: vers une archéologie de l'expérience (Aix-en-Provence: Alinéa, 1992).

66 Veja-se, por exemplo, Cristóbal Holzapfel, "Sobre el hombre lábil, el mal y la culpabilidad en Ricœur", disponível on-line em http://www.cristobalholzapfel.cl/ articulos/C.Ricoeur-mal.pdf 
convidou diversos especialistas de filosofia francesa em geral e do mundo ricœuriano em particular (para além do já citado Giannini, marcaram também presença Ana Escríbar Wicks da Universidad de Chile ou Gonzalo Portales, da Universidad Austral de Chile) e cujo foco era a hermenêutica dos símbolos e dos textos, promovendo ao mesmo tempo uma interação entre a hermenêutica ricœuriana da via longa e outras abordagens, como a desconstrução derridiana e mesmo outras áreas das ciências humanas e sociais. Outro tema importante da receção no Chile está ligado à ética, à bioética e à ética aplicada, sobretudo através dos trabalhos de Ana Escríbar Wicks. ${ }^{67}$ Uma via próxima investiga a questão ético-política, por exemplo nos trabalhos de Mariano de la Maza (PUC), que se debruçam sobre a questão do reconhecimento ou da filosofia prática em Hegel e Ricœur ${ }^{68}$, através da exploração da sabedoria prática, que tem sido feita com inegável mestria por Beatriz Contreras Tasso ${ }^{69}$ (PUC) ou ainda fundando uma ética e política da interculturalidade, caso da filosofia de Ricardo Salas Astrain. ${ }^{70}$ Finalmente, dois últimos temas são de mencionar: o interesse pela poética ricœuriana, não só no domínio filosófico e literário, mas também no da teologia ${ }^{71}$; e a área da fenomenologia. Em suma, o Chile permanece, hoje em dia, um

67 Veja-se nomeadamente Ana Escríbar Wicks, Ética Narrativa: antecedentes y posibles aportes al juicio moral (Santiago de Chile: Ediciones Universidad Diego Portales, 2013) e "La ética aplicada, sus condiciones de posibilidad y exigencias a las que responde" in Revista de Filosofía vol. 60 (2004): 19-28.

${ }^{68}$ Luis Mariano de la Maza, "Notas para una filosofía práctica interdisciplinaria. Aportes de la confrontación de Ricœur com Hegel” in Revista de Filosofia vol. 71 (2015): 31-51.

69 Veja-se Beatriz Contreras Tasso, La sabiduría práctica en la ética de Paul Ricour (Madrid: Plaza y Valdés, 2012).

70 Ricardo Salas Astrain, "Desde el reconocimiento a la interculturalidad" in Cuadernos del Pensamiento Latinoamericano n. ${ }^{\circ}$ 20: 56-75.

${ }^{71}$ Neste contexto, não se pode deixar de mencionar Eduardo Silva Arévalo, reitor da Universidade Alberto Hurtado, que tem pensado a poética teológica a partir de Ricœur. Ver em especial a sua obra Poética del relato y poética teológica. Aportes de la hermenéutica filosófica de Paul Ricour en Temps et récit para una hermenéutica teológica (Santiago de Chile: Anales de la Facultad de Teología, 2000). 
dos países onde a presença do pensamento de Ricœur se faz sentir com mais força, contando igualmente com uma nova geração de académicos ricœurianos particularmente ativos. ${ }^{72}$

Finalmente, também no México a presença da receção do pensamento de Ricour é especialmente importante, sendo de destacar as áreas da hermenêutica (incluindo análises da linguagem e da narratividade), da ética, da política e da pedagogia. Neste contexto, importa começar por mencionar a obra de Mauricio Beuchot Puente, filósofo mexicano com uma obra original e influente e que não só usa o Ricœur da La Metáfora Viva para pensar o plano da metáfora como, indo mais longe, propõe aquilo a que chama uma "hermenêutica analógica"73 para pensar a operação analógica em toda a sua extensão. Já Julieta Lizahola (UNAM) utiliza a o modelo interpretativo da ação humana de Ricœur e a sua noção de uma hermenêutica do sagrado na sua investigação sobre a obra de María Zambrano. ${ }^{74}$ Greta Rivara Kamaji, por seu lado, centra-se na análise ricouriana da relação entre linguagem e realidade para redefinir a questão da abertura da linguagem ao ser e remeter para a abertura da linguagem ao real extralinguístico. ${ }^{75}$ No que diz respeito à

\footnotetext{
72 Para além de todos os estudiosos já referidos, citem-se ainda as obras de Patricio Mena Malet, Presidente da ASIER, e autor de numerosos trabalhos de fenomenologia e hermenêutica (com especial ênfase na questão do acontecimento) e de Sebastián Kaufmann, especialmente no domínio da filosofia moral e política. Ver Patrício Mena Malet, Fenomenología por decir. Homenaje a Paul Ricour. Santiago de Chile: Ediciones Universidad Alberto Hurtado, 2006); Patricio Mena Malet, "Natalidad, acontecimiento y hospitalidad, reflexión a partir de las obras de Paul Ricœur y Claude Romano" in La lámpara de Diógenes n. ${ }^{\circ}$ 14-15 (2007): 90-102; Sebastián Kaufmann, "Repensando la autonomía: una reflexión desde Paul Ricœur" in Problemas Actuales de la Filosofía Jurídica, ed. Fabiola Vergara Ceballos (Santiago de Chile: Librotecnia, 2015).

73 Mauricio Beuchot, Tratado de Hermenéutica Analógica - Hacia un Nuevo Modelo de Interpretación (México: Editorial Itaca, 1997).

${ }^{74}$ Julieta Lizaola, Lo Sagrado en el Pensamiento de María Zambrano (México: Coyoacán, 2008).

75 Greta Rivara Kamaji, "El problema lenguaje-realidad en Paul Ricœur" in Paulina Rivero (coord.), Cuestiones Hermenéuticas. De Nietzsche a Gadamer (México: Ítaca, 2006), 105-124.
} 
relação entre a temporalidade, a narratividade e a historiografia é imperioso referir as importantes obras de Luis Vergara Anderson e Alfonso Mendiola Mejia, ambos da Universidad Iberoamericana. Respondendo aos três tomos de Tiempo e Narración, Vergara publica, por sua vez, uma trilogia ${ }^{76}$ na qual repensa alguns dos principais conceitos ricœurianos: memória, ética, reconhecimento, gesto, para além das já mencionadas temporalidade e narrativa. Já Mendiola ${ }^{77}$ dedica a sua atenção à análise historiográfica de Ricœur e à noção de sentido, na relação entre textualidade e textura. Por fim, importa igualmente mencionar os trabalhos de José Juan Sainz Luna (UNAM) e César Correa Arias (Universidad de Guadalajara). Luna desenvolve uma análise que se ancora parcialmente na economia do dom de Ricœur e que, com Levinas, interroga a questão do justo meio para a fundamentação do reconhecimento social pela via ética-política, buscando o exercício de uma vida digna e de emancipação do sujeito da ação. César Correa Arias ${ }^{78}$ desenvolve o seu trabalho em torno da viragem pedagógica como evolução da viragem linguística para a viragem narrativa. Apoiando-se na fenomenologia hermenêutica de Ricœur, tenta ligar os conceitos de identidade narrativa (Ricœur) e imaginação narrativa (Nussbaum) para pensar a pedagogia, nesta relação, como cultivo da humanidade.

\footnotetext{
${ }^{76}$ Luis Vergara Anderson, La Producción Textual del Pasado I: Paul Ricœur y su teoría de la historia anterior a La Memoria, la Historia, el Olvido (México: Universidad Iberoamericana / Instituto Tecnológico y de Estudios Superiores de Occidente, 2004); La Producción Textual del Pasado II: Fundamentos para una lectura crítica de la teoría de la historia de Paul Ricœur (México: Universidad Iberoamericana, 2010); La Producción Textual del Pasado III: una lectura crítica de la teoría de la historia de Paul Ricœur. Implicaciones filosóficas y ético-políticas (México: Universidad Iberoamericana, 2011).

77 Veja-se por exemplo Alfonso Mendiola Mejía, "La narrativa como forma de reflexividad de los procesos de los sistemas sociales" in Alfonso Mendiola y Luis Vergara (coord.), Cátedra Edmundo O’Gorman. Teoría de la história vol. 1 (México: UIA, UNAM, 2011), 99-112.

${ }^{78}$ Veja-se, por exemplo, César Correa Arias, "Monolinguism of Other as a Limit of a Narrative Identity. Retelling the University Today" in Mediterranean Journal of Social Sciences vol. $4 \mathrm{n} .{ }^{\circ} 9$ (October 2013): 682-688.
} 
Esta lista não exaustiva de países e estudiosos historicamente ligados à receção, divulgação e discussão do pensamento de Ricœur mais não pretende que servir como recordação do forte enraizamento e da marca indelével da sua presença no espaço ibero-americano. Porém, esta série e o presente dossier temático não visam apenas uma recordação do passado; à sua maneira, olham também para o futuro, e para a fecundidade das análises ricœurianas, se aplicadas a temas especificamente ibero-americanos. Assim sendo, passemos a apresentar o conteúdo deste número inaugural, (composto por cinco capítulos e dois testemunhos incluídos no dossier temático e uma secção de varia) que poderá ser lido a seguir a esta introdução.

O primeiro par de capítulos tem como objetivo principal focar de forma específica a receção do pensamento de Ricœur na Península Ibérica. Se, no primeiro capítulo, da autoria de Francisco José García Lozano, e intitulado "La hermenéutica en España: la recepción de la obra y pensamiento de Paul Ricœur" o objetivo é traçar a história da receção da obra e pensamento de Ricœur em Espanha de uma forma geral, situando-a no contexto mais alargado da presença da hermenêutica em Espanha, o segundo capítulo, "A receção do pensamento histórico de Ricœur na historiografia portuguesa: Fátima Bonifácio e Fernando Catroga", de Martinho Soares, incide sobre uma questão muito mais específica, a saber, a forma como as contribuições de Ricœur para a prática historiográfica e a epistemologia da história tiveram uma influência decisiva em dois dos mais importantes historiadores portugueses contemporâneos. Na sua história da receção, García Lozano invoca Ortega y Gasset como precursor do pensamento hermenêutico em Espanha e relembra o trabalho pioneiro de figuras como Schökel, Panikkar, Lledó e Conill (entre muitas outras) que, cada uma à sua maneira, abriu portas ao trabalho hermenêutico neste país. O resultado é que, hoje em dia, a hermenêutica é reconhecida em Espanha como uma filosofia de pleno direito, com diferentes praticantes e divulgadores. Para isso 
muito terão contribuído as filosofias de Heidegger ou Gadamer. Mas também, com toda a certeza, a de Ricœur. García Lozano traça o mapa dos diversos domínios do pensamento ricœuriano tipicamente trabalhados por autores espanhóis, elegendo a fenomenologia, a hermenêutica geral, a antropologia hermenêutica, a temporalidade/ narratividade, a hermenêutica simbólico-religiosa, a hermenêutica da ação e a justiça como os domínios deste pensamento mais frequentemente trabalhados sob a perspetiva ricœuriana.

O capítulo de Soares centra-se numa questão específica, a receção do pensamento histórico de Ricœur na historiografia portuguesa. Soares começa por notar que, em Portugal, as reflexões de carácter epistemológico sobre a tarefa dos historiadores são raras, assinalando duas exceções: Fátima Bonifácio e Fernando Catroga. Depois, todo o capítulo consiste numa discussão minuciosa da forma como as reflexões ricœurianas sobre a epistemologia da história são apropriadas ou criticadas por ambos os historiadores. Soares mostra como as abordagens de ambos são muito diferentes entre si. Se, por um lado, Bonifácio parece estar mais preocupada em chamar à colação a discussão epistemológica para justificar o seu próprio método histórico, que recupera a história política e factual, Catroga assume-se como um verdadeiro pensador da ciência histórica. Soares relembra a recorrência do pensamento sobre a história na obra de Ricœur, desde História e Verdade até A Memória, a História, o Esquecimento, elencando as suas teses principais. O capítulo mostra como Bonifácio se apoia sobretudo nas teses de Tempo e Narrativa para desenvolver um esforço histórico narrativo e, para além disso, uma postura epistemológica assumidamente narrativista. Já Fernando Catroga desenvolve uma reflexão mais ampla, que se inspira de Ricœur mas não só e na qual é apropriada de forma mais específica a dialética entre explicação e compreensão no trabalho do historiador - distanciando-se assim, pelo menos de forma parcial e como também o faz Ricour, de uma história pura e simplesmente narrati- 
va. Tendo em conta estes elementos, Soares acaba por concluir que, independentemente do mérito inegável do seu trabalho, a apropriação que Bonifácio faz de Ricœur é parcial enquanto a presença do pensamento deste filósofo na obra de Catroga, sendo mais fiel ao pluralismo das metodologias históricas, também acaba por estar mais de acordo com o espírito das reflexões de Ricœur sobre a história.

Um segundo grupo de capítulos debruça-se sobre questões práticas, de aplicabilidade política, e que consistem em análises de conflitos em diferentes países da América latina, recorrendo a noções tipicamente ricœurianas, como as de vítima, sujeito capaz, ou perdão. No capítulo "La víctima como sujeto capaz. A propósito del conflicto colombiano" o autor Manuel Prada Londoño dá conta de algumas conclusões de um grupo de trabalho que, em 2010 e 2011, analisou o conflito colombiano e que, entre outros objetivos, pretendia deliberar sobre o estatuto das vítimas. Londoño mostra como a questão sobre as vítimas foi abordada a partir da confluência das perspetivas de vários autores (Benjamin, Reyes Mate, Ricœur) e referindo como a visão ricœuriana foi importante para conceder às vítimas o estatuto de sujeitos de direito, dignos de estima e respeito. Nesta operação, trata-se de valorizar os esquecidos da história, neste caso, perante a violência de um conflito armado de longa duração. A antropologia filosófica de Ricœur mostra-se útil para o fazer porque consiste numa afirmação ontológica das capacidades de base de cada ser humano; e Londoño argumenta que o processo de recuperação das vítimas passa por restituir-lhes as capacidades que, muitas vezes, lhes foram negadas. Este processo passa então, na tese do autor, por processos de reconhecimento mútuo que envolvam os diferentes atores sociais, o Estado e a sociedade civil, tudo elementos indispensáveis para a ação em comum e a construção de instituições justas. Neste contexto, as reflexões ricœurianas mostram a sua utilidade para tentar enquadrar da melhor forma possível alguns dos mais injustiçados por um dos conflitos mais graves na América Latina. 
Já o capítulo de Esteban Lythgoe, intitulado "Los límites del perdón ricœuriano desde la perspectiva argentina" adota uma abordagem crítica do modelo ricœuriano de perdão, tentando perceber até que ponto a história recente da Argentina pode ou não ser compreendida a partir deste prisma. Lythgoe recorda a definição ricœuriana de perdão, recolocando-a no contexto do debate que Ricœur tem com outros autores, como Hegel, Arendt, Derrida e Abel. O autor deste capítulo vê, neste modelo proposto por Ricœur, não só uma aplicabilidade ética na relação entre dois indivíduos, mas também uma possível finalidade política: a da reconciliação nacional. Lythgoe leva a cabo uma discussão honesta e sem reservas dos méritos e problemas do modelo ricœuriano, recolocando também a questão no contexto da polémica que teve lugar pouco tempo depois da publicação de A Memória, a História, o Esquecimento, com o violento ataque de Badiou, e a defesa de Dosse. Segundo Lythgoe, podemos distinguir dois modelos de perdão: um monopolar, o outro bipolar. O primeiro teria sido defendido por Derrida; o segundo, por Ricœur, na senda de Hegel. Para Derrida, o perdão seria um fim em si mesmo, fora de qualquer lógica de intercâmbio. Para Ricœur, seria a relação de interação intersubjetiva e a renúncia à posição particular de cada um que permitiria a reconciliação. O objetivo principal do capítulo de Lythgoe é o de mostrar os limites do perdão, tomando como exemplo a ditadura argentina de 1976-1983 e o subsequente processo de reconciliação nacional, mais tarde revogado. Na opinião de Lythgoe, este caso mostra que o perdão pode acabar por beneficiar mais quem comete o crime do que as vítimas dele. Assim, o modelo ricœuriano seria talvez apropriado para pensar o caso sul-africano, mas não o argentino, uma vez que foi graças ao facto de a pressão cidadã, e das organizações de direitos humanos, ter levado a tribunal os perpetradores de crimes que foi possível fazer justiça às vítimas. Cada um à sua maneira, os capítulos de Londoño e Lytghoe mostram assim, sob diferentes perspectivas, as vantagens e limites 
da filosofia ricœuriana quando aplicada à questão sempre espinhosa de saber como lidar com vítimas de processos violentos.

O último capítulo do dossier temático deste número, da autoria de Aníbal Fornari, intitulado "Temporalidad, acontecimiento y poder", é de grande fôlego e também toca, à sua maneira, na questão argentina. Neste capítulo, Fornari desenvolve uma vigorosa reflexão sobre o exercício do poder, nas suas relações com a temporalidade, chamando a atenção para a importância das experiências de passividade na relação com a alteridade e também para o carácter inescapável dos acontecimentos na configuração da nossa experiência humana. Para o fazer, o autor aborda um grande número de temáticas, partindo das reflexões ricœurianas sobre a temporalidade, sobretudo a partir da leitura que Ricour faz de Santo Agostinho em Tempo e Narrativa, passando pela ênfase arendtiana na natalidade e pelo que ela nos ensina sobre o poder como capacidade de trazer a novidade ao mundo e culminando numa reflexão sobre a capacidade dos povos hispano-americanos e, sobretudo, a Argentina, de exercer o poder de forma adequada e constituir comunidade. Fornari pretende criticar a tendência do poder para se reificar e ser exercido de forma violenta, naquilo que é um esquecimento e uma negligência do poder em comum exercido no viver-juntos de uma comunidade e para cuja importância tanto Ricœur como Arendt tanto chamavam a atenção. De facto, para Fornari, o exercício autêntico do poder político implica o reconhecimento do sentido relacional da pluralidade e radica no consentimento à decisão renovada de se viver em comum, o que envolve ir para lá da vontade de dominação e do recurso à violência. Ora, na sua conclusão, o autor questiona, no momento da celebração do bicentenário da libertação e fundação de diversos Estados sul-americanos, se de facto tem sido possível constituir tais comunidades sem uso de violência; relembrando, com Juan Bautista Alberdi, que a libertação na América do Sul se fez, em muitos casos, pela força da violência, Fornari nota, também 
seguindo Alberdi, que este facto muitas vezes resultou em sociedades civis fracas e frequentemente ameaçadas pela brutalidade de uma violência que parece passar do ato fundador de libertação para a imposição da força do Estado enquanto tal. Neste pano de fundo, Fornari propõe que, por um lado, se reconheça o elemento de conflitualidade presente nas múltiplas perspetivas presentes nas sociedades pluralistas mas que, por outro, isso se faça num clima de complementaridade e de respeito pelo carácter pacífico das relações em sociedade. Ou, nas palavras de Fornari, fomentando uma "criatividade relacional". Finalmente, termina o capítulo lamentando que, no caso da sua Argentina natal, tal comunidade política em sentido estrito ainda não se tenha propriamente podido constituir, perdida que tem estado, segundo Fornari, numa história de lutas fratricidas. Porém, a conclusão do autor também conta com uma nota de esperança em relação à possibilidade de transição para um estado de coisas em que se possa estabelecer uma verdadeira divisão de poder e uma capacidade da sociedade perdoar os problemas do passado, naquilo que é um contraponto em relação à conclusão do capítulo de Lythgoe.

Finalmente, o dossier temático deste número fecha com uma contribuição especial. Ela consiste em dois breves testemunhos de duas figuras muito importantes na difusão do pensamento de Ricœur em língua portuguesa, e sobretudo no Brasil, país que, como dissemos, acolheu em 2017 o congresso mais recente da ASIER. Ambos se pronunciam sobre a importância e os traços específicos da filosofia ricouriana. O primeiro de entre eles é da autoria de Jeanne Marie Gagnebin e foi recolhido por Patrícia Lavelle. Quanto ao segundo, foi confiado a Claudio Reichert do Nascimento, a quem agradecemos a permissão para o publicar aqui em acesso livre. Infelizmente, pouco tempo após ter enviado esta contribuição, o Professor Japiassu dei- 
xou de estar entre nós. ${ }^{79}$ Este breve testemunho reveste-se, pois, de particular importância, uma vez que não só condensa a sua opinião sobre o grande legado de Paul Ricœur à filosofia contemporânea como também terá sido, porventura, uma das últimas vezes que o filósofo brasileiro se pronunciou sobre a obra de alguém que ele tanto fez por honrar e difundir. Assim sendo, a esta homenagem de Hilton Japiassu a Ricour junta-se a nossa, ao próprio Professor Japiassu, que assim fica ligado ao início desta nova fase dos estudos ricœurianos no espaço ibero-americano.

A secção varia deste primeiro volume é composta por dois capítulos, o último dos quais uma recensão. O capítulo de Vinicius Oliveira Sanfelice, intitulado "Esboço para uma dimensão estética em Paul Ricœur" analisa a dimensão estética da obra ricœuriana tomando como ponto de partida e modelo a sua teoria da imaginação e, sobretudo, a teoria da metáfora. O autor destaca a centralidade da questão da inovação semântica e do excesso de sentido na estética ricœuriana, sublinhando o carácter inovador da imaginação poética. Através deste tipo de imaginação, tal como aparece exemplificado na metáfora, uma obra de arte é capaz de transformar a realidade. Sanfelice assinala assim as possíveis ligações entre a poética ricœuriana e uma estética. Porém, construir estas ligações, elevá-las a algo que seja mais que um esboço, implica ainda, segundo o autor, "tomar em amplitude a releitura do mundo-da-vida operada pela me-

79 Claudio Reichert do Nascimento encontrou-se pessoalmente com Hilton Japiassu no mês de novembro de 2014, aquando do III Encontro Internacional dos Bacharelados e Licenciaturas Interdisciplinares, que teve lugar na Universidade Federal do Sul da Bahia em Porto Seguro. Tendo em conta o futuro lançamento da Ricoeuriana, contactou posteriormente o Professor Japiassu a 8 de fevereiro de 2015 com um pedido de entrevista para ser incluído neste número. A resposta de Japiassu chegou sob a forma da contraproposta de prestar este testemunho, em vez da entrevista, tendo ele sido enviado no dia 9 de fevereiro de 2015. Reproduzimo-lo aqui na íntegra, com edições meramente estilísticas. Infelizmente, o Professor Japiassu viria a falecer, com uma repentina paragem cardíaca, no dia 27 de abril de 2015, aos 81 anos de idade. 
taforização e testá-la em outro vocabulário". Ao escolher debruçar-se sobre este tópico, Sanfelice coloca-nos na pista de uma das temáticas - a imaginação e a metáfora - que, certamente, será explorada de forma muito mais aturada no futuro, sobretudo tendo em conta a publicação, que se espera para breve, do curso sobre a imaginação (as Lectures on Imagination, proferidas em Chicago, nos anos 70), e ao qual esta série dedicará certamente bastante atenção no futuro.

A secção varia termina com uma recensão, da autoria de Marcos Alonso Fernández, ao livro editado por Tomás Domingo Moratalla e Agustín Domingo Moratalla, intitulado Bioética y hermenéutica. La ética deliberativa de Paul Ricour, livro de atas de um congresso internacional que teve lugar em Valência em 2013, aquando do Centenário de Ricœur.

Financiamento: A investigação de Gonçalo Marcelo beneficia da bolsa de pós-doutoramento (SFRH/BPD/102949/2014) da Fundação para a Ciência e a Tecnologia (FCT) bem como do Projeto Estratégico do Centro de Estudos Clássicos e Humanísticos (UID/ELT/00196/2013). César Correa Arías pertence à Red de estudios Socio-históricos en educación, financiada pela Secretaría de Educación Pública de México e é membro do Sistema Nacional de Investigadores, financiado pelo CONACYT (Consejo Nacional de Ciencia y Tecnología) - México. 



\title{
LA HERMENÉUTICA EN ESPAÑA：LA RECEPCIÓN DE LA OBRA Y PENSAMIENTO DE PAUL RICAER
}

\author{
HERMENEUTICS IN SPAIN: THE RECEPTION \\ OF PAUL RICEUR'S THINKING AND WORKS
}

Francisco José García Lozano Facultad de Teología, Granada ${ }^{1}$

Resumen: La hermenéutica en España empieza a tomar fisonomía a raíz de la publicación y traducción de la obra de Gadamer Verdad y método en los años 70. Tras ella, la hermenéutica ha ido implantándose poco a poco en el ámbito español con figuras tan relevantes como Schökel, Lledó, Ortiz-Osés o Panikkar, entre otros. Desde esa década el paradigma hermenéutico español no ha dejado de enriquecerse con innumerables propuestas. En este capítulo nos acercaremos a algunas de las principales ideas que ha generado la hermenéutica española, centrándonos en la recepción de la obra y pensamiento de Paul Ricour.

Palabras clave: filosofía hermenéutica; hermenéutica española; Paul Ricœur.

\footnotetext{
${ }^{1}$ Francisco José García Lozano, Calle Neptuno 5, 18004 Granada, España. E-mail: frangarcialozano@gmail.com
} 
Abstract: Hermeneutics in Spain begins to take form as a result of the publication and translation of the Gadamer's work "Truth and Method" (Wabrheit und Methode) in the 1970s. After it, hermeneutics has been implemented gradually throughout the country by outstanding figures such as Schökel, Lledó, Ortiz-Osés or Panikkar, among others. Since then the Spanish hermeneutical paradigm has not stopped to be enriched with countless proposals. In this article we will consider some of the main ideas generated by the Spanish hermeneutics, focusing on the acceptation of Paul Ricœur's work and thought.

Keywords: philosophical hermeneutics; Paul Ricour; Spanish hermeneutics.

\section{Introducción}

La hermenéutica se ha ganado un lugar propio y diferenciado dentro del atomizado marco de "tradiciones" de pensamiento contemporáneo, siendo la koiné o el lenguaje común de la tardomodernidad. ${ }^{2}$ El siglo pasado estuvo marcado por la estela de Heidegger, cuya filosofía en torno a la "constitución del sentido" ha sido considerada a menudo como el hilo conductor y denominador común del pensamiento filosófico contemporáneo. ${ }^{3}$ Sin embargo, lo heterogéneo de las propuestas filosóficas del siglo pasado y el agotamiento de muchas de ellas ha propiciado que la hermenéutica se haya manifestado como el nuevo paradigma de la modernidad. Tal preponderancia se debe, especialmente, a que

\footnotetext{
${ }^{2}$ G. Vattimo, Ética de la interpretación (Barcelona: Paidós, 1991), 60-61.

3 Cfr. H-G. Gadamer (ed.), Das Problem der Sprache. Achter deutscher Kongress für Philosophie (Munich: Wilhelm Fink Verlag, 1966).
} 
la hermenéutica propone un método más afín a la realidad del siglo XXI, en el sentido de que resulta más eficaz para abordar problemáticas tales como la libertad de acción, la responsabilidad moral, la identidad, la individualidad, entre tantas otras. ${ }^{4}$ Comprender e interpretar, para decirlo con Heidegger, más allá de un instrumento específico de la filología o la historiografía, constituyen nuestro propio modo de estar en el mundo, la esencia de nuestra mundaneidad.

Que a lo largo de este proceso hasta los paradigmas filosóficos de contornos más definidos hayan perdido su unidad interna es cosa que resultaría difícil de negar. Entendida durante siglos como interpretación normada de textos eminentes (teológicos, filológicos y jurídicos), la hermenéutica no ha dejado de vivir también, desde su revitalización por Dilthey, cuando menos, su propia explosión hasta la gran obra de Hans-Georg Gadamer, Verdad y método (1960), foco de las realizaciones contemporáneas en el paradigma de la comprensión. La obra representa una inflexión lingüístico-interpretativa en el filosofar, que reclama sus tesis especialmente de Schleiermacher, Dilthey y Heidegger. Al igual que Schleiermacher, Gadamer se propone elaborar una teoría universal del comprender y de los modos todos de comprensión. Con ello la hermenéutica entra en el giro lingüístico de la filosofía contemporánea.

En España tal giro llegaría relativamente tarde. Julián Marías, uno de los grandes conocedores de la España del siglo pasado, de su filosofía y creatividad cultural, exponía en los años sesenta un

\footnotetext{
${ }^{4}$ Algún autor como J. Grondin relaciona el renacer de las cuestiones hermenéuticas a crisis epocales. Según Grondin, "Aunque estos momentos han sido detectados a menudo retrospectivamente, es decir, desde la óptica de la historiografía actual, se puede decir que estaban relacionados con experiencias de rupturas de tradiciones que provocaron un interés más intenso por el problema de la interpretación y su teoría hermenéutica", en J. Grondin, Introducción a la hermenéutica filosófica (Madrid: Herder, 1999) 43.
} 
certero diagnóstico de lo que había sido la filosofía española del siglo XX:

En España no existía, simplemente, una tradición filosófica creadora; los filósofos españoles dignos de este nombre son una serie de oasis aislados en un desierto, y si nos alejamos hacia el pasado, pasando por Suárez, Luis Vives y Raimundo Lulio, nos encontramos en la España árabe o judía - Averroes, Maimónides - o, más allá aún, en la "España" romana - Séneca. En el siglo XIX, las figuras más estimables - Balmes, Sanz del Río - estuvieron muy lejos de poseer una filosofía original y adecuada. Fue Unamuno el que, sin hacer filosofía, sino más bien negándola, ofreciendo en su lugar "fantasmagoría o mitología" (o simplemente novelas y poemas), puso en el centro de la atención y la preocupación española el problema de la filosofía, el que crea así las condiciones para el renacimiento - en rigor, nacimiento - entre nosotros. Y fue Ortega (1883-1955) quien lo realizó, con una radicalidad y plenitud no superadas, acaso no igualadas por ningún pensador de nuestro tiempo. 5

Como muy bien señala Julián Marías, Ortega y Gasset representa esa nueva regeneración de la filosofía española, marcada, por el contexto epocal en el que se genera, por un inevitable corte hermenéutico que analizaremos a continuación y, a partir, de él adentrarnos en otros desarrollos hermenéuticos.

5 J. Marías, Los españoles (Madrid: Revista de Occidente, 1963), 254-255. 


\section{La hermenéutica en España}

La hermenéutica en España ${ }^{6}$ tendrá como precursor a J. Ortega y Gasset (1883-1955), cuya filosofía remite a Dilthey en su fundamentación de una razón viviente o vital y su perspectivismo. Para Dilthey, al sujeto ideal de la Crítica de la razón pura le faltaba una característica fundamental de la vida misma: su dimensión histórica, el estar "arrojado" en un mundo, una época y un lugar determinados. Ortega denominaría a esta característica "su circunstancia", la cual no resulta indiferente a la hora de conocer, interpretar, valorar.

En las primeras líneas del opúsculo de Ortega y Gasset El tema de nuestro tiempo, donde se recoge la lección inaugural del curso universitario de 1921-1922, podemos ubicar las principales líneas de su proyecto hermenéutico:

Nuestro pensamiento pretende ser verdadero; esto es, reflejar con docilidad lo que las cosas son. Pero sería utópico y, por tanto, falso suponer que para lograr su pretensión el pensamiento se erige exclusivamente por las cosas, atendiendo sólo a su contextura. Si el filósofo se encontrase solo ante los objetos, la filosofía sería siempre una filosofía primitiva. Mas junto a las cosas halla el investigador los pensamientos de los demás, todo el pasado de meditaciones humanas, senderos innumerables de exploraciones previas, huellas de rutas ensayadas a través de la eterna selva problemática que conserva su virginidad, no obstante su reiterada violación. ${ }^{7}$

${ }^{6}$ A. Ortiz-Osés, "Hermenéutica española", en A. Ortiz-Osés y P. Lanceros (eds.), Diccionario de hermenéutica (Bilbao: Universidad de Deusto, 2004), 177-180.

7 J. Ortega y Gasset, El tema de nuestro tiempo, en Obras Completas, vol. III (Madrid: Alianza Editorial, 1983), 145. 
En este texto contemplamos cómo uno de los pilares sobre los que construye Ortega y Gasset su filosofía será la respuesta del pensamiento a la situación humana y vital del sujeto, constituyéndose como uno de los ejes fundamentales de su ontología. Junto a esto, la idea del "ser" que pone en juego Ortega y Gasset implica la no aceptación de la realidad como objetiva, pero tampoco como una proyección arbitraria de la subjetividad del sujeto. De esta manera su epistemología se revela como una actividad hermenéutica, por un lado, y su ontología como el resultado de esa praxis interpretativa.

Sin embargo, como señala Ortiz-Osés, tendríamos que considerar a Luis Alonso Schökel (1920-1988) como el primer gran hermeneuta español, que consideró todo su obra como un aporte hermenéutico, bajo un tema específico: los textos literarios, cuyos muchos ejemplos y apartados proceden del ámbito bíblico. Así explica su propia teoría de la comprensión-interpretación:

¿Existe la quinta Sinfonía de Beethoven? Sí, la hemos escuchado muchas veces. Es cierto, hemos podido escuchar diversas interpretaciones de esa pieza musical. Porque la música no existe más que cuando se ejecuta la partitura; ésta no es más que un registro, una forma de conservar el mensaje escrito mediante una serie de escritos convencionales. Primero hay que dominar los signos, sabes qué es cada uno, cuánto tiempo vale, a qué nota se refiere, en qué clave está escrito el conjunto. Una vez comprendidos los signos, éstos pueden ser interpretados: es entonces cuando se produce la música, cuando cobra vida la obra significada en la partitura. ${ }^{8}$

Schökel desarrolló su actividad hermenéutica desde dos planos bien diferenciados. Uno partiendo de una hermenéutica general,

${ }^{8}$ L. A. Schökel, Apuntes de hermenéutica (Madrid: Trotta, 1994), 18. 
como teorización sobre la comprensión-explicación e interpretación de los textos literarios y una hermenéutica específica, la de los textos bíblicos, en los que a partir del método histórico-crítico se acercó al tratado de la inspiración bíblica como forma de entroncar el texto religioso y su explicación en el hecho del lenguaje y de la obra literaria. Hay paralelismo y continuidad entre el cambio de la teoría de la inspiración y el cambio de la teoría hermenéutica. Todos estos aspectos son recogidos en una breve obra, Apuntes de hermenéutica, donde destila lo más sintético de sus años de docencia.

Mención merece también la labor desarrollada por el catalán Raimon Panikkar (1918-2010) y su "filosofía comparativa", donde el término "comparar" se entiende como aquella actividad de la mente humana que toma una postura neutral con respecto a las cosas comparables. Por lo que toda filosofía se considera una filosofía comparativa en la medida en que ésta se compara a sí misma con otras visiones filosóficas. Es el estudio filosófico de uno o algunos problemas a la luz de más de una tradición. Desde este planteamiento, Panikkar desarrolla su particular hermenéutica, que denomina "hermenéutica diatópica" que describe de la siguiente manera:

Yo la llamo la hermenéutica diatópica, en cuanto que la distancia a superar no es meramente temporal, dentro de una única y amplia tradición, sino que es la distancia que existe entre los tópoi humanos, "lugares" de comprensión y autocomprensión, entre dos (o más) culturas que no han elaborado sus modelos de inteligibilidad... La hermenéutica diatópica parte de la consideración temática de que es necesario comprender al otro sin presuponer que éste tenga nuestro mismo autoconocimiento y conocimiento de base. Aquí está en juego el último horizonte humano y no solamente contextos diferentes entre sí. ${ }^{9}$

9 R. Pannikar, Mito, fe y hermenéutica (Barcelona: Herder, 2007), 23. 
Busca, entre otras cosas, superar el círculo hermenéutico creado por los límites de una sola cultura, esto es, la hermenéutica diatópica intenta poner en contacto horizontes humanos radicalmente diferentes, tradiciones o lugares culturales (tópoi) diferentes, para lograr un verdadero diálogo dialógico que tenga en cuenta las diferentes culturas.

Un tercer baluarte de la filosofía hermenéutica española viene representado por Emilio Lledó, cuya filosofía se sustenta, por una parte, en la hermenéutica filosófica de H.-G. Gadamer; por otra, en el lenguaje como "energeia"; es decir, el lenguaje, como había dicho con anterioridad el propio Heidegger, también "habla" (Die sprachespricht). Lledó también cultiva con esmero las ideas de su maestro: la concepción hermenéutica del lenguaje, la historicidad de la comprensión, la pertenencia a una tradición, la rememoración y el reconocimiento del pasado, etc. Lledó, lo mismo que Gadamer, defiende la autonomía de la obra escrita en relación con su creador, lo que implica, por una parte, abrir desde el tiempo silencioso de lo escrito el otro tiempo de la escritura, que es el tiempo del lector. "El lógos escrito (lógosgegramménos), no es lógos si no recibe el tiempo del lector". ${ }^{10}$ De este modo se produce la apertura hacia las infinitas formas de decir que determinan la finitud de nuestra propia existencia y al mismo tiempo el diálogo infinito que el futuro ofrece a los innumerables lectores. "Con la escritura - afirma Lledó - la memoria alcanza un grado superior de intersubjetividad que aquel que se manifiesta en el inmediato diálogo del hombre con otro hombre, o del hombre consigo mismo". ${ }^{11}$

Referencia obligada es la "ética hermenéutica impura" propuesta por Jesús Conill. El autor sabe que una comprensión radical del ser humano, como la que él intenta ofrecer, está siempre transida de la

${ }^{10}$ E. Lledó, El surco del tiempo (Barcelona: Crítica, 1992), 95.

11 Ibid., 52. 
dimensión ética y práctica. En este sentido estamos de acuerdo con el profesor Conill cuando opina que

necesitamos, pues, una ética de carácter hermenéutico, cuyo significado universal pase a través de la nueva noción experiencial de "interpretación" y de una nueva "crítica" en forma de autocomprensión, más allá de la autoconciencia idealista, una ética donde tanto la interpretación como la autocomprensión estén "siempre en camino". En el camino de la experiencia, donde lo que siempre sucede es un acontecer de requerimientos y de expectativas de sentido. ${ }^{12}$

Una ética hermenéutica crítica, en este sentido, permitiría diseñar una ética de la responsabilidad en contextos complejos y plurales, como el actual. Una ética crítica que mira hacia el pasado y hacia el futuro, intentando dar nombre a lo que nos pasa en el presente.

Los cauces abiertos por P. Ricœur, de manera indirecta, se ven reflejados en la labor filosófica que llevan realizando desde hace años autores como Andrés Ortiz-Osés y Patxi Lanceros, cuyo fruto más destacable es su Diccionario de Hermenéutica y en la misma senda Claves de Hermenéutica.

Andrés Ortíz-Osés es considerado como uno de los principales hermeneutas representante del mundo hispano, en la construcción de una nueva filosofía hermenéutica, pionero en nuestro país en la introducción del pensamiento hermenéutico centroeuropeo y de la escuela de Heidegger. La aportación específica de su obra radica en la elaboración de una "Hermenéutica simbólica" del sentido, cuya categoría clave es la de "coimplicación" y "fratriarcalismo" que estructuran su pensamiento en la búsqueda de conceptos cohesionadores. Él mismo reconoce cómo la génesis de su hermenéutica encuentra en

${ }^{12}$ J. Conill, Ética hermenéutica (Madrid: Tecnos, 2006), 146. 
P. Ricœur, a partir de su concepción del simbolismo como mediación entre la remitologización del sentido arcaico y su desmitologización crítica, materiales imprescindibles para su filosofía simbólica: "El sentido es la sutura simbólica de fisura real", 13 aforismo a partir del cual Ortíz-Osés reorienta simbólicamente su hermenéutica. Su tarea se puede concebir así como una filosofía simbólica que plantea una crítica profunda, al igual que hace P. Ricœur, al modelo ilustrado racionalista occidental: "La filosofía occidental ha tergiversado el amor a la sabiduría (simbólica) como un amor al ser (racionalístico). Se impone así un tipo de saber no-sapiencial, insipiente, funcional y funcionarial, que se encuentra en la gran corriente ilustrada su lumbre, lustre y lastre. Podríamos hablar de Filosofía simbólica, por contraposición a la Filosofía racionalista oficial". ${ }^{14}$

El interés de la filosofía ortiz-osesiana está en haber planteado la cuestión candente de la identidad personal y humana no de un modo fundamentalista sino hermenéutico y abierto. Su proyecto hermenéutico pretende una interpretación simbólica de la metafísica clásica presidida por una serie de oposiciones (ser/devenir, acto/ potencia, sensible/inteligible, doxa/episteme, materia/forma, etc.) en la que uno de los términos obtiene una valoración positiva y otro queda cargado de connotaciones negativas. Pues bien, la tarea de la hermenéutica simbólica cultivada por Ortiz-Osés consiste precisamente en el intento de suturar (simbólicamente) esa herida real. Una sutura que debe darse también en un plano antropológico, de un "humanismo hermenéutico" en el que lo específico humano es la interpretación simbólica que descentra al sujeto en virtud de lo que consiente: "El hombre trata de remediar simbólicamente la propia escisión producida por su misma aparición a través de un lenguaje

13 A. Ortiz-Osés, Las claves simbólicas de nuestra cultura (Barcelona: Anthropos, 1993), 45.

${ }^{14}$ A. Ortiz-Osés, "Prólogo. Filosofía simbólica", en P. Lanceros, La herida trágica (Barcelona: Anthropos, 1997), XI. 
suturador. El lenguaje hermenéutico constituye ese espacio abierto (celeste) del tiempo humano-terrestre del sentido, el cual es más que lo mentado: lo consentido". ${ }^{15}$

Igualmente, Patxi Lanceros comparte la misma noción de hermenéutica que Ortíz-Osés, ya que comparece como la contextura "en la que se constituye la verdad posible (parcial y episódica), dado que el hombre y el mundo son, desde el punto de vista de las ciencias de la cultura, conjuntos significativos, formas simbólicas o urdimbres de sentido, en los que co-inciden interpretación y lenguaje". ${ }^{16}$ Lanceros abre el camino para la concepción de un sistema que dé cuenta de las relaciones, de las transiciones entre los diversos ámbitos de la experiencia, sin poder aspirar a ninguna suerte de cierre o clausura, sin poder de-finirse o de-terminarse. Una hermenéutica del sentido que sea capaz de hallar una confluencia entre las diferentes perspectivas, entre las diferentes miradas que pueden posarse en el objeto real.

La obra de Lanceros, La herida trágica, parte igualmente desde el planteamiento crítico que A. Ortiz-Osés hace desde su filosofía simbólica como sentido e implicación. Con ecos al "cogito herido" ricœuriano, Lanceros ensaya una "Hermenéutica a la vez sim-bólica y dia-bólica. Implicación, límite, herida trágica”. Cómo él mismo señala: "La herida trágica se configura como lo abierto (Rilke), el silencio (Hölderlin), la ausencia (Nietzsche). Es el espacio que hemos identificado como el hay del peligro, o como realidad que deja ser (y no-ser) al manifestarse en (la) contradicción y, por lo tanto, al sustraerse en cuanto plenitud o unidad". ${ }^{17}$

15 Cf. A. Ortiz-Osés, Amor y sentido. Una hermenéutica simbólica (Barcelona: Anthropos, 2003).

16 P. Lanceros, "Antropología Hermenéutica", en A. Ortiz-Osés y P. Lanceros (eds.), Diccionario de hermenéutica, 20.

17 P. Lanceros, La herida trágica, 207. 
Esta radicalidad ontológica de la herida impele a la búsqueda de formas de sutura que, si nunca terminan de recomponer la unidad rota, impliquen los fragmentos en dispersión. He aquí la función del símbolo: "se pueda afirmar que, en un sentido radical, toda sutura es simbólica y todo símbolo ha de ser comprendido como vínculo o sutura". 18

Destacar, por último, otros proyectos como el realizado por Javier Recas con su propuesta de reconstrucción de una nueva hermenéutica crítica en clave de diálogo. Diálogo con Gadamer, obviamente, por razones históricos y sistemáticas; diálogo con la gran tradición hermenéutica; y, diálogo, finalmente, entre las distintas perspectivas del criticismo hermenéutico. Una hermenéutica consciente de la escisión entre lo patente y lo oculto, atendiendo a los síntomas, inquisidora del sentido soterrado bajo las formas manifiestas; una hermenéutica situada entre la hermenéutica de las tradiciones y la crítica de las ideologías (la Ideologiekritik). Recas reconoce en la nueva hermenéutica crítica contemporánea (Gadamer, Habermas, Apel, Vattimo, Rorty, Derrida y Ricœur), que, a pesar de sus discrepancias, heterogeneidad y personalidad propias, "hay en la obra de todos ellos una actitud común de profundización crítica respecto al estándar ontofenomenológico de la hermenéutica tradicional, frente al que reclaman el reconocimiento del potencial crítico inscrito en todo otorgamiento de sentido, y la necesidad de una hermenéutica profunda, de huellas y síntomas, frente a la mera recolección del significado"19.

18 P. Lanceros, "Sentido", en A. Ortiz-Osés y P. Lanceros (eds.), Diccionario de hermenéutica, 513.

19 J. Recas Bayón, Hacia una hermenéutica crítica. Gadamer, Habermas, Apel, Vattimo, Rorty, Derrida y Ricœur (Madrid: Biblioteca Nueva, 2006), 27. 


\section{La recepción de la obra y pensamiento de P. Ricour en España ${ }^{20}$}

Un hecho constatado por muchos es la tardía recepción de la obra de P. Ricœur en España. Su primer libro, Karl Jaspers et la philosophie de l'existence, es de 1947, y su primera obra importante, Philosophie de la volonté. Finitude et culpabilité I-II, de 1960, es traducida al castellano en 1969, con introducción de José Luis Aranguren. Un destacado conocedor de la obra ricœuriana, Marcelino Agís, señala los motivos personales que motivaron a $\mathrm{P}$. Ricœur el posponer su visita a nuestro país: "En una ocasión le pregunté por qué tardó tanto en visitar nuestro país. Me contestó, entonces, que prefirió esperar al fin de la dictadura para hacerlo. En alguna ocasión, Ricœur expresó públicamente esta misma idea de aguardar a que España recuperase la libertad y la democracia para visitarla". ${ }^{21}$

No resulta fácil abordar la recepción del pensamiento de P. Ricœur en el panorama español, debido principalmente a la diversidad de temas y preocupaciones que siempre rondaban a un pensador tan inquieto como él. Sin embargo, hemos de reconocer que casi la totalidad de temas que preocuparon al pensador francés han sido abordados desde sus múltiples perspectivas en España. De un modo esquemático y que no agota los horizontes intelectuales de los si-

\footnotetext{
20 Para una información más detallada cfr. F. D. Vansina, Paul Ricœur. Bibliography 1935-2008 (Lovaina: Leuven University Press, 2008).

${ }^{21}$ M. Agís Villaverde, "Paul Ricœur en España”, en José Luis Mora García, Delia Manzanero, Martín González, Xavier Agenjo Bullón (eds.). Crisis de la Modernidad y Filosofías Ibéricas. X Jornadas Internacionales de Hispanismo Filosófico (Madrid: Fundación Ignacio Larramendi, 2013), 481. El artículo de Agís Villaverde hace un recorrido por las localizaciones geográficas más destacadas por las que ha pasado $P$. Ricœur (Granada, Madrid, Cataluña, Santiago de Compostela y Galicia), y la huella bibliográfica, principalmente colaboraciones en congresos, que ha dejado en ellas. Para nuestro fin más interesante nos parece la aportación de Alfredo Martínez Sánchez titulado "Recepción de Paul Ricœur en español: bibliografía en castellano", en Ideas $y$ Valores 127 (2005): 73-98. Este artículo nos permite reconstruir la introducción de la obra de P. Ricœur desde 1969, la primera traducción, hasta 2003.
} 
guientes pensadores, podríamos señalar diversos campos típicamente ricœurianos trabajados desde el pensamiento español:

En la perspectiva de la fenomenología podemos citar a: Tomás Domingo Moratalla ${ }^{22}$ y Antonio Pintor-Ramos, ${ }^{23}$ entre otros;

Desde la perspectiva de una hermenéutica general podemos nombrar a Marcelino Agís Villaverde, ${ }^{24}$ Agustín Domingo Moratalla ${ }^{25}$ o Manuel Maceiras, ${ }^{26}$ entre otros;

La antropología hermenéutica por Leonides Fidalgo Benayas, ${ }^{27}$ Manuel A. Basombrío, ${ }^{28}$ Francisco Javier Rodríguez Buil29 y María Belén Tell, 30 entre otros;

22 T. Domingo Moratalla, Creatividad, ética y ontología. La fenomenología hermenéutica de P. Ricœur (Madrid: Universidad Pontifica de Comillas, 1996).

${ }^{23}$ A. Pintor Ramos, "Paul Ricœur, fenomenólogo", en Cuadernos salamantinos de filosofía 6 (1981): 135-156. "Paul Ricœur y la fenomenología", en T. Calvo Martínez y R. Ávila Crespo (eds.), Paul Ricoeur: Los caminos de la interpretación. Symposium internacional sobre el pensamiento filosófico de Paul Ricœur. Granada, 23-27 de noviembre de 1987 (Barcelona: Anthropos. 1991).

${ }^{24}$ M. Agís Villaverde Del símbolo a la metáfora: introducción a la filosofía hermenéutica de Paul Ricour (Santiago de Compostela: Servicio de Publicaciones de la Universidad de Santiago de Compostela, 1995); (ed.), Horizontes de la Hermenéutica (Santiago de Compostela: Servicio de Publicaciones de la Universidad de Santiago de Compostela, 1998); Conocimiento y razón práctica (Madrid: Fundación Emmanuel Mounier, 2013).

25 A. Domingo Moratalla, Introducción al pensamiento de Paul Ricœur. Esperanza militante y creatividad reflexiva (Madrid: Instituto Emmanuel Mounier, 1991).

${ }^{26}$ M. Maceiras y J. Trebolle, La hermenéutica contemporánea (Madrid: Ediciones Pedagógicas, 2004).

${ }^{27}$ Leonides Fidalgo Benayas, Hermenéutica y existencia humanas. El pensamiento de Paul Ricoeur (Valladolid: Universidad de Valladolid, 1996).

28 Manuel A. Basombrío, De la filosofía del yo a la hermenéutica del sí mismo: un recorrido a través de la obra de Paul Ricour (Málaga: Universidad de Málaga, 2008).

${ }^{29}$ Francisco Javier Rodríguez Buil, Antropología de la alienación según la filosofía del sujeto de Paul Ricœur (Madrid: Fundación Universitaria Española, 2003).

30 María Belén Tell, Tras la huella del testimonio. Estudio filosófico sobre los silenciosos alcances de la antropología hermenéutica de Paul Ricour (Salamanca: Universidad de Salamanca, 2015). 
La cuestión de la temporalidad/narratividad ha sido tematizada exhaustivamente por Mariano Peñalver, ${ }^{31}$ Ángel Gabilondo $^{32}$ y Gabriel Aranzueque; ${ }^{33}$

Aportaciones a la hermenéutica simbólico/religiosa podemos encontrarlas en la labor de Jesús E. Albertos ${ }^{34}$ o Jorge Pérez de Tudela y Velasco, ${ }^{35}$ entre otros;

La hermenéutica de la acción ha sido trabajada por Francisco José García Lozano; ${ }^{36}$

Sobre la temática de hermenéutica y justicia ha trabajado profusamente Xavier Etxebarría Mauleón ${ }^{37}$ y Teresa Picontó. 38

Debido a la amplitud de enfoques y abordajes temáticos, nos ceñiremos aquí a aquellos que consideramos más significativos y que ofrezcan una panorámica general de la recepción del pensamiento de P. Ricœur en España.

Como señalábamos antes, Philosophie de la volonté. Finitude et culpabilité I-II, es traducida al castellano en 1969. En ella José Luis

${ }^{31}$ M. Peñalver, La búsqueda del sentido en el pensamiento de P. Ricoeur (Sevilla: Publicaciones de la Universidad de Sevilla, 1978).

32 A. Gabilondo, "La intriga y la trama: la Poética de Aristóteles", en T. Calvo Martínez y R. Ávila Crespo (eds.), Paul Ricœur: Los caminos de la interpretación, 397-406.

33 G. Aranzueque (coord.), Horizontes del relato. Lecturas y conversaciones con Paul Ricœeur (Madrid: Cuaderno Gris, 2001).

${ }^{34}$ Jesús E. Albertos, El mal en la filosofía de la voluntad de Paul Ricœur (Navarra: Eunsa, 2008).

35 J. Pérez de Tudela y Velasco, "Desvelamiento y revelación: el círculo hermenéutico en Paul Ricœur", en T. Calvo Martínez y R. Ávila Crespo (eds.), Paul Ricour: Los caminos de la interpretación, 369-383.

${ }^{36} \mathrm{~F}$. J García Lozano, Los caminos de la acción. Un recorrido a través de la obra de Paul Ricour (Murcia: Editorial Espigas, 2015).

37 Xavier Etxebarría Mauleón, Imaginario y derechos humanos desde Paul Ricœur (Bilbao: Desclee de Brouwer, 1995).

38 T. Picontó Novales, Hermenéutica, argumentación y justicia en Paul Ricœur (Madrid: Editorial Dykinson, 2005). 
Aranguren hace una breve presentación del pensamiento de Ricœur resaltando, precisamente, el vacío existente en nuestro país de un pensador tan relevante en el ámbito europeo: "Considero un gran acierto editorial la traducción de este bello libro, de tan claro interés interdisciplinar, que apareció en Francia va para diez años, y cuyo autor es relativamente poco conocido en nuestro país". En esta breve presentación para el público español, Aranguren sitúa las raíces del pensamiento de Ricœur en Merleau-Ponty, Gabriel Marcel y Karl Jaspers, definiéndolo como el pensador más abierto y razonable de Francia y considerándolo una referencia obligada para el diálogo de la teología, la antropología y, en general, la filosofía. Anteriormente sólo teníamos alguna recensión de dicha obra en algunas publicaciones españolas como la de M. Mindán (1954) o B. Waldenfels (1965).

Tras la traducción de esta obra de P. Ricœur, Finitud y culpabilidad, empezarán a publicarse algunos acercamientos de los que solamente citamos algunos, a modo de ejemplo, para hacer ver la repercusión y recepción de su obra en los años sucesivos:

P. Trevijano Echevarría publicará dos interesantes reflexiones en torno a la esperanza en P. Ricœur: "La dimensión horizontal de la esperanza en el pensamiento de Paul Ricœur" (1972); "La dimensión vertical de la esperanza en el pensamiento de Paul Ricœur" (1972);

C. Díaz y M. Maceiras, Introducción al personalismo actual (1975). En esta obra, entre los muchos autores que comentan, incluyen una entrada al pensamiento de P. Ricœur;

A. Pintor Ramos, "Paul Ricœur y el estructuralismo" (1975);

M. Maceiras, "Ricour, Paul". Diccionario de filosofía contemporánea (1976). 
Sin embargo, una de las primeras reflexiones sistemáticas en torno al pensamiento de P. Ricœur fue la abordada en los años 70 por Mariano Peñalver en su obra La búsqueda del sentido en el pensamiento de Paul Ricour (1978). Como señala Peñalver, Ricœur se propuso elaborar una poética de las experiencias de creación y recreación, poética que constituiría una verdadera filosofía de la Trascendencia. La poética como disciplina descriptiva que es alude, tal como lo indica su raíz griega (fabricación de algo que resulta ser diferente de su autor), al carácter productivo de algunos tipos de discurso (sin distinguir entre prosa y poesía) y también del simbolismo. Ricœur reconoce en los símbolos una singular potencia de invención o creación, es decir, de producción de sentido, la cual implica a su vez una función heurística, que es un poder de descubrimiento o invención de rasgos inéditos de la realidad, de aspectos inauditos del mundo, pero cuya fuente sigue ubicándose en la forma del pensar: "La forma de pensar puede así comprenderse como la superabundancia de sentido que excede su desarrollo al contenido pensado determinado (suscitado, alimentado) por su carácter originario, por su entorno histórico". ${ }^{9}$ De hecho, podríamos definir como de optimismo ilustrado la conclusión de M. Peñalver: "Porque sólo bajo la forma del pensamiento abierto un sentido puede darse a los otros". ${ }^{40}$

En otro sentido, M. Peñalver ha abordado la filosofía de Ricœur desde lo que ha denominado "pensamiento de la intersección", que es aquel "que situándose entre el pensamiento de la recolección (al modo de Gadamer) y el pensamiento del a diseminación (al modo de Derrida), nos ofrece y nos hace habitar aquellas encrucijadas

39 M. Peñalver, "Ricœur: la forma del sentido", en Paul Ricœur. Discurso filosófico $y$ hermeneusis, Revista Anthropos 18 (1998): 83.

40 Ibid., 86. 
donde se sitúan los conflictos y perplejidades". ${ }^{41}$ Un pensamiento de intersección que se desarrolla a un doble nivel. A un "nivel dialógico", es decir, en relación de posición del discurso respecto a los otros discursos, como a un "nivel dianoético", es decir, en proceso mismo de constitución de sí mismo. Un "nivel dialógico" que apunta hacia el "entreambos", que "es el modo de pensar hermenéutico que punta a un inédito cuya conexión con los discursos ya formulados no consiste en recoger lo mínimo común entre ellos sino en la búsqueda simultánea de la distancia (el entre) y el de la fusión (el ambos), es decir, del lugar desde donde puedan ser pensadas sin contradicción la diferencia y la conciliación".

A un "nivel dianoético", esto es, lo concerniente al movimiento que adopta un pensar en la efectuación de su despliegue como discurso, se configura como un "desde-hacia", donde "el término desde contiene una idea de origen, de procedencia, y el término hacia una idea de dirección de un movimiento respecto al punto al que se abre. Ambos términos apuntan a la actualidad de un ya donde se encierra el contenido semántico de lo originario y de lo futuro". ${ }^{42}$

Ricœur reconoce que este segundo nivel ha sido sobre el que más ha incidido y el que más productivo se le ha revelado: "Está muy claro que es este segundo nivel el que más ha atraído mi atención, aunque lo que se dijo del primero no carezca de interés". 43

La preocupación por la ontología es constante en la obra de Ricœur y, de hecho, es una de las cuestiones que más reflexión ha generado en su recepción dentro del panorama hispánico. Por ceñir nuestro tema nos centraremos en la recepción y reflexión llevada a cabo por Manuel Maceiras y Juan Manuel Navarro Cordón.

41 T. Calvo Martínez, y R. Ávila Crespo, (eds.), Paul Ricour: Los caminos de la interpretación, 349-349.

42 Ibíd., 342.

43 Ibid., 364. 
Según Manuel Maceiras, en "Paul Ricœur: una ontología militante", en la obra de Ricœur encontramos una "intención ontológica que desea alcanzar el ser del yo, entendido como primera persona”, ${ }^{44}$ preocupación ontológica que responde "a una convicción igualmente ontológica”. Maceiras identifica algunos presupuestos básicos de la filosofía de Ricœur, que marcan su planteamiento de la ontología; el primero es la convicción de que el yo es "acto más que forma, afirmación viva" ${ }^{45}$ esto es, no es posible la intuición del yo por sí mismo: reflexión e intuición no se identifican. Toda reflexión es hermenéutica, lo que significa que toda identidad del yo queda pendiente de la interpretación: ser es igual a "ser interpretado". De todo ello se deriva lo siguiente: ya que no es posible una hermenéutica única y universal, sino que son varios los posibles caminos de interpretación, sólo es posible lo que Maceiras llama una "ontología militante", no separada, contingente e incluso revocable. Sería una ontología fragmentaria, pues ella va haciendo aparecer aspectos reales pero siempre parciales del ser. Por último, el símbolo adquiere una significación ontológica, pues sólo siguiendo la intencionalidad del símbolo podemos acceder a parcelas de lo real.

Según el artículo de Maceiras, la obra de Ricœur es, por medio de una gran complejidad temática, un desarrollo coherente de estos presupuestos. Se refiere en primer lugar al proyecto de la filosofía de la voluntad, que Ricœur lleva a cabo parcialmente: a la eidética corresponde Le volontaire et l'involontaire; de la empírica no tenemos más que la introducción en $E l$ hombre lábil y en La simbólica del mal; finalmente, la poética concluiría la ontología del sujeto, "con un nuevo cambio de método, ya que incluiría la trascendencia"46.

44 T. Calvo Martínez y R. Ávila Crespo, (eds.), Paul Ricour: Los caminos de la interpretación, 46.

45 P. Ricœur, Historia y verdad (Madrid: Encuentro Ediciones, 1990), 369.

46 Ibíd., 55. 
Poética, señala Maceiras, que está implícita, por ejemplo, en La metáfora viva y en Tiempo y narración, pero siempre en el contexto fundamental de una "ontología militante o identificación del sujeto a través de los signos". ${ }^{47}$

Maceiras señala cómo también en la confrontación de Ricœur con el estructuralismo aparece la búsqueda ontológica, en su insistencia de romper la cerrazón del lenguajes sobre sí mismo y de abrirse al ser del lenguaje. Esta vehemencia ontológica se prolonga no sólo en sus estudios sobre la metáfora y la narración, sino en sus trabajos sobre el lenguaje bíblico.

A la interpretación de Maceiras, Ricœur responde ratificando la tesis de la imposibilidad del acceso directo al yo, tesis que marca el distanciamiento con respecto a la filosofía existencial. Ricour mismo matiza su ontología iniciática al señalar en Sí mismo como otro, cómo el acceso indirecto del yo queda subrayado pro el paso del vocabulario del "yo" al vocabulario del "sí" reflexivo y en donde desarrolla la tesis de la atestación como el modo epistemológico apropiado para acercarse a la ontología del sí.

Igualmente Ricœur da la razón a Maceiras cuando este relaciona la "afirmación originaria", el acto de ser del yo, con el conatus de la Ética de Spinoza y el appetitus de la Monadología de Leibniz, y sugiere que es por medio de estos dos filósofos "como nos es posible quizá reactualizar esta parte de la ontología aristotélica que no está captada en la teoría de la sustancia sino que marca la independencia de la significación acto-potencia por relación a la serie de categorías que gravitan en torno a la sustancia". ${ }^{48}$

Otra aproximación a la ontología ricœuriana la encontramos en lo que podemos llamar la "ontología de la libertad". En esta línea está escrito el artículo "Existencia y libertad: sobre la matriz ontológica

\footnotetext{
47 Ibid., 56.

48 Ibíd., 72.
} 
del pensamiento de P. Ricœur", de Juan Manuel Navarro Cordón; el autor sostiene la tesis de una "matriz ontológica" en la que puede encontrarse el hilo conductor y la clave última de la variada y plural temática de la obra de Ricœur, articulándola en torno a los temas de "existencia y libertad", es decir, "un sujeto que es existencia y se sabe y actúa como libertad". ${ }^{4}$

Navarro Cordón señala una estrecha circularidad entre reflexión, existencia y libertad; a partir de aquí, identifica en las obras de Ricœur, sobre todo hasta la década de los setenta, una serie de temas ontológicos: el esfuerzo y el deseo de ser que expresan la "falla existencial" de la que habla en Finitud y culpabilidad, el lenguaje en el que se expresa ese deseo de ser, el sentimiento "que me une a las cosas, a los seres, al ser", la desproporción entre finitud e infinitud que "constituye el lugar ontológico entre el ser y la nada" y, finalmente y sobre todo, la libertad como modo de ser en el "acto" de existir, ya que es el originario y fundamental.

En su respuesta a Navarro Cordón, Ricœur empieza por reconocer que "siempre me sentí intimidado por la cuestión ontológica, siendo por otro lado muy consciente de su urgencia", recurriendo a una imagen bíblica para referirse a su postura ante la ontología: "A veces se me ocurrió escribir que mi filosofía se dirigía quizá al umbral de la ontología pero sin franquearlo, como un Moisés, al que se le prohíbe entrar en la tierra prometida". ${ }^{50} \mathrm{Al}$ igual que con Maceiras, Ricœur apunta al paso del yo-soy al sí-mismo como la expresión correcta que mejor recoge todas las personas gramaticales y que permite el paso del ¿quién habla? al ¿quién obra?, ¿quién hace memoria?..., en sí, "la búsqueda de un sujeto de imputación y responsabilidad"51, reconociendo incluso un "retroceso" en La me-

\footnotetext{
49 Ibíd., 150.

50 Ibíd., 188.

51 Ibid., 192.
} 
táfora viva y Tiempo y narración con respecto a las afirmaciones ontológicas de sus trabajos anteriores.

Sin embargo, señala en este ámbito tres puntos de su filosofía en los que no ha hecho ninguna concesión: la subordinación de la conciencia a la posición en el ser del sujeto mismo, la subordinación del lenguaje al ser-dicho que lo convoca, la convicción de que el ser que somos es tanto esfuerzo (afirmación), como deseo (ausencia, falta, ausencia). Estas tres convicciones se resumen en la fórmula que afirma el primado del yo soy sobre el yo pienso.

En la trayectoria del pensamiento filosófico de Ricœur, el paso de la década de los sesenta a la década de los años setenta supone un viraje importante en su propia concepción de la hermenéutica, el concepto de "palabra" o "discurso" reemplaza paradigmáticamente al de símbolo, efectuando un importante ensanche hermenéutico en su propia concepción filosófica. Frente a este cambio hermenéutico se han dado posturas encontradas y contrarias, dos acercamientos importantes, uno a favor de la tesis de la ruptura, Tomás Calvo, y otro en contra, José $\mathrm{M}^{\mathrm{a}}$. Rubio Ferreres, vienen a sintetizar el debate que se generó en su momento.

La teoría del texto supone por una parte la salida del psicologismo de la hermenéutica tradicional y, por otra, el paso a la textualidad como clave hermenéutica permite tomar al texto como modelo a aplicar a otros campos de la filosofía y de las ciencias humanas tales como el campo de la ciencia histórica o de la reflexión ética bajo el prisma de la acción intencionada. Todo ello hace postular a Tomás Calvo el concepto de "ruptura" en la reflexión filosófica de P. Ricœur y la apertura de un horizonte teórico sustancialmente nuevo: "creo, en primer lugar, que el cambio que va del símbolo al texto comporta una transformación radical de la concepción de la hermenéutica y no un mero ensanchamiento o ampliación del objeto de ésta". 52

52 Ibid., 128. 
Tomás Calvo señala cómo Ricœur, en su confrontación con el estructuralismo, lo aborda desde sus mismas claves, esto es, desde la oposición sistema-acontecimiento y lengua-discurso. Sin embargo, la introducción en el concepto de discurso de la distinción "discurso hablado-discurso escrito" es lo que obliga a Ricœur a la subsiguiente ruptura en su concepto hermenéutico:

Y es precisamente esta distinción, como hemos visto, la que lleva a cambiar radicalmente el panorama al poner en primer término los rasgos que acercan el discurso escrito a la lengua ( $\sin$ que por ello deje de ser discurso), rasgos que permiten replantear la relación entre comprensión y explicación a la vez que fundamentan de un modo totalmente nuevo la necesidad y la tarea de la hermenéutica. ${ }^{53}$

Ricœur por su parte no pretende entrar a discutir la tesis mantenida por T. Calvo, sino que su propósito "el de reflexionar con él acerca de la cuestión misma". ${ }^{54}$ Ricœur localiza la problemática en el interior mismo de la noción de "discurso" y los elementos que se derivan de ello. El momento del habla se divide en dos momentos. El primero consiste en decir algo, es el momento de la idealidad del lenguaje, de la expresión del sentido; la idealidad de este momento se funda en que el sentido de lo dicho no existe ni en el mundo ni en la conciencia, no tiene realidad en sí mismo. El segundo momento surge porque el hablar implica decir algo sobre algo, es el momento de la realidad, en que lo dicho toca la realidad. Es por ello que toda palabra o habla significante supone lo que Ricœur llama los dos umbrales de significación: umbral de sentido (ideal) y umbral de referencia (real). El habla distingue y articula los dos umbrales de

\footnotetext{
53 Ibid., 132.

54 Ibid., 142.
} 
significación: el sentido y la referencia del discurso, el decir algo y hablar sobre algo. El discurso como acto del habla puede pasar a la escritura. Para Ricœur este paso a la escritura no es simplemente la fijación material de la palabra viva, sino más bien el establecimiento de una relación específica con las cosas dichas: "Me parece que el problema se origina en la dificultad que hay en ordenar correctamente, en el interior mismo del discurso, el componente léxico, digamos la palabra, y el componente sintáctico, digamos la frase, y más allá de ella, la propia discursividad".55

Ricour se limita a la exposición, pero no entra a discutir la tesis de T. Calvo, por la razón de que, aunque no lo afirme directamente, ubica tal problemática en un momento anterior a la teórica bifurcación de las dos hermenéuticas. Desde su talante conciliador difícilmente Ricœur aceptaría el concepto de "ruptura" que postula T. Calvo, sin embargo sí aceptaría una cierta "discontinuidad" que no entraría en contradicción con lo postulado por T. Calvo: "Ninguna de mis observaciones contradice la tesis de Tomás Calvo sobre la discontinuidad entre la hermenéutica de los símbolos y la hermenéutica del texto. Pretenden solamente situar esta discontinuidad en el segundo plano de problemas previos a la bifurcación entre las dos hermenéuticas". 56

José $\mathrm{M}^{\mathrm{a}}$. Rubio Ferreres parte de la misma constatación que Tomás Calvo, un viraje en el planteamiento hermenéutico de P. Ricœur, aunque con derivaciones distintas. El mismo José $\mathrm{M}^{\mathrm{a}}$. Rubio se muestra taxativo en su planteamiento: "El principal motivo, a nuestro juicio, de este cambio de insistencia - subrayamos "cambio de insistencia" puesto que nos oponemos a la tesis de la "ruptura" del pensamiento

55 Ibíd., 142.

56 Ibíd., 144. 
de Ricœur - fue la toma de conciencia, cada vez más clara, del carácter lingüístico de la experiencia humana". ${ }^{57}$

De hecho, José $\mathrm{M}^{\mathrm{a}}$. Rubio Ferreres localiza en la relación "lenguaje-experiencia humana-realidad" el eje central del pensamiento de Ricœur. Para Rubio Ferreres estamos siempre ante un problema de lenguaje, y así lo constata en el mismo Ricœur, ya que desde el principio lo que intenta Ricœur es injertar la filosofía lingüística en la fenomenología, es decir, estamos ante el hecho de la creatividad semántica del lenguaje, hecho marcado por la ambigüedad y por el doble sentido. La hermenéutica es para Ricœur una filosofía de la interpretación cuyo objeto fundamental es la palabra, palabra que es potencia, que tiene el poder de desplegar el ser nuevo que anuncia. Para poder desplegar ese ser nuevo, la palabra se sirve del sistema de signos que conforma el lenguaje. El lenguaje es la estructura que permanece independiente de quien habla, es una mediación, un vehículo que nos permite dirigirnos hacia la realidad. Sin embargo, para que el lenguaje alcance toda su riqueza necesita el acto del habla, si no permanece estructura, permanece simplemente como instrumento.

Rubio Ferreres desarrolla, a colación de la reflexión misma de P. Ricœur, una "hermenéutica del lenguaje religioso" centrando su análisis en cómo P. Ricœur introduce la cuestión hermenéutica en una reflexión filosófica sobre el discurso o texto religioso: "Partimos de la tesis, según la cual, el lenguaje religioso, en tanto lenguaje poético o metafórico, es un 'discurso ficticio', aunque no desprovisto de 'referencia veritativa', según hemos afirmado antes. ¿Qué significa esto? Que en el discurso religioso, como en cualquier otro discurso, es pro-puesta siempre la cosa o mundo del texto a través de las distintas formas de discurso" 58 .

57 Ibíd., 219.

58 Ibíd., 227. 
En la hermenéutica religiosa de Ricœur, lo Sagrado permanece como manifestación anticipadora, pero que aún no poseemos, in fieri, sobre la que se hace necesaria una hermenéutica crítica para con caer en ideologías, bajo un nuevo precepto que recogerá en $L a$ simbólica del mal: "Hay que comprender para creer y hay que creer para comprender".

Ricœur reconoce lo ejemplar y clarificador de la propuesta de José $M^{a}$. Rubio que ha sabido llevar sus propuestas lingüísticas hasta sus últimas consecuencias: "Lleva lo más lejos posible la exploración de las fuentes del lenguaje, que el fenómeno religioso maneja y la hermenéutica filosófica explora. Vuelve a encontrar en la dialéctica entre manifestación (de lo sagrado) y proclamación (del kerygma) una estructura hermenéutica comparable a la que gobierna la relación entre símbolo y metáfora. Este acercamiento es sin duda muy clarificador". 59

Juan Masiá ha calificado el proyecto filosófico de P. Ricœur como "el arte de la mediación", un arte de la mediación entre "existencia y razón", "comprensión y explicación", "ficción y realidad", "tiempo y eternidad", "heteronomía y autonomía" y entre "filosofía y teología": "Ricour es el filósofo de la mediación por excelencia. Conjuga lo francés, lo alemán, lo anglosajón. Acepta y critica lo existencial, lo fenomenológico, lo hermenéutico" ${ }^{60}$. La postulación de lo humano como animal hermenéutico transido e interpretado a través de signos, símbolos y textos.

Masiá resume la trayectoria filosófica de Ricœur bajo la fórmula: "del deseo de narrar a la narración del deseo". Un "deseo de narrar" que nos remite al tema de su filosofía de la voluntad: desemboca en la hermenéutica de los símbolos y acaba confrontando el conflicto

59 Ibid., 245.

60 J. Masiá Clavel y T. Domingo Moratalla, Lecturas de Paul Ricour (Madrid: Universidad Pontificia de Comillas, 1998), 7. 
con las diversas hermenéuticas. Un "deseo de narrar" que se desdobla en un primer periodo (Lo voluntario y lo involuntario, 1950; Finitud y culpabilidad, 1960) y un segundo periodo (Sobre Freud, 1965; El conflicto de las interpretaciones, 1969), que son reflejo de las dos caras de su hermenéutica: "una esperanzada y otra angustiada, una sugeridora y otra cuestionadora, una que redescubre los símbolos y otra que destruye los símbolos". ${ }^{61}$

En los años 70 y 80 Ricœur proyecta y desarrolla, según Masiá, la segunda parte del lema citado: del "deseo de narrar" a la "narración del deseo". Aquí será la narración la portadora y configuradora del deseo. Dos son las obras claves: La metáfora viva (1975) y Tiempo y narración (1983-85). "Del deseo de narrar a la narración del deseo" es la fórmula con la que Masiá condensa la clave del estilo de filosofar de Ricour: el arte de la mediación, de tender puentes y derribar fronteras.

Igualmente importante es el trabajo realizado por Tomás Domingo Moratalla. Tomás Domingo en su tesis doctoral, Creatividad, ética y ontología. La fenomenología hermenéutica de Paul Ricœur, ya abordó la totalidad de la obra de Ricœur bajo la óptica de lo que ha denominado como "fenomenología poética". Con ello Domingo Moratalla quiere indicar que la hermenéutica de Ricour es una hermenéutica fenomenológico-reflexiva cuya pretensión es recuperar el ser del yo (nivel ontológico) en las producciones en que éste muestra su efectividad (nivel lingüístico-hermenéutico) a través, siempre, del trabajo del concepto (nivel metodológico). Todo ello es, en el fondo, una tarea ética que pide por parte del sujeto responsabilidad: "Este recorrido es el que quiero indicar con la expresión fenomenología poética: la palabra poética crea, inventa, y así, al crear, descubre la realidad en y por un ser que es imaginación y posibilidad; realidad

61 Ibid., 11. 
siempre finita, y también, por la acción del habitar poético, siempre abierta". ${ }^{62}$

Desde esta "fenomenología poética", Ricœur aborda los tres hitos sobre los que ha desarrollado su reflexión: el "yo", que se correspondería con el momento reflexivo, el "Mundo", donde ha desarrollado su idea de referencia, refiguración e iniciativa en el mundo, y el "Otro" como constitutivo de mi ipseidad. Yo-Mundo-Otro como constitutivos del triángulo hermenéutico de la experiencia. Ciertamente, Ricœur no ha de dejado de insistir continuamente que el objetivo último de la filosofía es comprender la experiencia humana, en su amplitud y complejidad.

La manera adecuada de acercarse a Ricœur sería la siguiente: pasamos de la creatividad en el discurso (poética) a la creatividad en la acción (ética), para acceder al fundamento de la creatividad (ontología). Y a la vez pone de manifiesto el concepto de razón derivado de este camino (razón hermenéutica), que nace del triángulo hermenéutico de la experiencia (yo-mundo-otro)". ${ }^{63}$

\section{Conclusiones}

La pregunta por el sentido y la pertinencia de la hermenéutica encuentra su debida respuesta en su confrontación con las distintas corrientes de pensamiento que han marcado el siglo Xx: la fenomenología, el estructuralismo, la estética, la ética, la retórica, la poética o la semiótica. Esta confrontación sucesiva con distintas corrientes y disciplinas puede utilizarse sin duda como punto de referencia para analizar la evolución y los cambios de perspectiva operados en el

62 Ibíd., 127.

63 Ibíd., 129. 
pensamiento hermenéutico y su pertenencia en la actualidad hasta hoy. Lo constitutivo de la hermenéutica es su estar diseminada en esa pluralidad de mediaciones.

La hermenéutica es la filosofía de los nuevos tiempos, dice acertadamente Vattimo. La hermenéutica es ejercicio cotidiano, siempre problemático, atento a las dinámicas del mundo contemporáneo y sus problemáticas. Era necesario y pertinente, por lo tanto, un análisis de la recepción de la hermenéutica en el panorama hispánico y sus principales rostros.

A pesar de la tardía recepción de la hermenéutica, en su sentido más restringido y usual, caracterizada por el pensamiento de autores como Hans-Georg Gadamer (1900-2002) y Paul Ricœur (1913-2005), podemos hacer un balance muy positivo de la recepción de la hermenéutica en España. Todas las visiones que hemos recorrido, necesariamente parciales, configuran el rostro de la hermenéutica hoy.

Las obras y autores citados en este capítulo son complementarios y convergentes con las obras sobre hermenéutica filosófica publicado en los últimos años en el ámbito hispánico. En primer lugar, el libro editado por J. J. Acero, J. A. Nicolás, J. A. Pérez Tapias, L. Sáez J. F. Zúñiga, El legado de Gadamer (2004) que recoge las actas del Congreso Internacional sobre Hermenéutica Filosófica que tuvo lugar en dicha ciudad entre el 10 y el 12 de diciembre de 2003 es un buen ejemplo de ello, que junto a las actas del Symposium Internacional sobre el pensamiento filosófico de Paul Ricoeur, Paul Ricoeur: los caminos de la interpretación (1991), constituyen una panorámica casi completa de la recepción de la hermenéutica filosófica en España.

En segundo lugar, los números monográficos de revistas dedicados a la hermenéutica filosófica no han dejado de sucederse (en la revista Diálogo Filosófico 61, 2005, Endoxa 20, 2005, Estudios Filosóficos 156, 2005), al igual que constantes homenajes y congresos tras el fallecimiento de Paul Ricœur (Hermenéutica y responsabilidad. Homenaje a Paul Ricour, 2005; II Seminario Internacional: 
Centenario Paul Ricœur: tiempo, dolor y justicia, organizado por la UNED, 2013).

Aunque sin duda hemos de resaltar de entre todos el trabajo coordinado por A. Ortíz-Osés y P. Lanceros con su Diccionario de hermenéutica. Una obra interdisciplinar para las ciencias humanas (2004) y Claves de hermenéutica. Para la filosofía, la cultura y la sociedad (2005), continuación de la anterior. La edición del Diccionario de hermenéutica constituye un acontecimiento cultural digno de mención por dos motivos, en primer lugar, por su novedad no sólo en el ámbito de lengua castellana sino a nivel mundial, y en segundo lugar, por la atinada selección de conceptos así como por los especialistas que los elaboran resultando un trabajo de calidad manifiesta. Igualmente Claves de Hermenéutica: para la filosofía, la cultura y la sociedad, es una obra colectiva en la que un conjunto de especialistas de relevancia nacional e internacional en las distintas áreas del conocimiento articula respuestas diversas a esos nuevos retos y a esos nuevos riesgos, replanteando las cuestiones candentes en torno al sentido en la postmodernidad. En la senda del Diccionario de Hermenéutica, estas Claves pretenden ofrecer pautas de interpretación y comprensión, presentándose como propuesta múltiple y abierta. Como respuesta plural a los diferentes temas y problemas que se plantean en un mundo a la vez unificado y conflictivo.

Concluimos, sin voluntad de clausura, esta aproximación en la que la diversidad de voces, armonizan positivamente en un legado hermenéutico que se va elevando poco a poco, y sigue haciéndolo, en el horizonte de la reflexión española. Son muchas las aportaciones que quedan fuera, pero nada se cierra aquí, los intersticios, huecos e involuntarias omisiones son oportunidades para crecer en el diálogo y ampliar horizontes de reflexión. En hermenéutica nada se cierra definitivamente y esta aportación queda totalmente 
abierta, pues como señala Gadamer, mala hermenéutica es aquella que quiere quedarse con la última palabra.

\section{Bibliografía}

Acero, J. J., Nicolás, J. A., Pérez Tapias, J.A., Sáez L y Zúñiga, J.F., El legado de Gadamer. Granada: Universidad de Granada, 2004.

Agís Villaverde, M. Del símbolo a la metáfora: introducción a la filosofía hermenéutica de Paul Ricour. Santiago de Compostela: Servicio de Publicaciones de la Universidad de Santiago de Compostela, 1995.

- (ed.). Horizontes de la Hermenéutica. Santiago de Compostela: Servicio de Publicaciones de la Universidad de Santiago de Compostela, 1998.

- Conocimiento y razón práctica. Madrid: Fundación Emmanuel Mounier, 2013.

Albertos, J. E. El mal en la filosofía de la voluntad de Paul Ricoeur. Navarra: Eunsa, 2008.

Aranzueque G. (coord.), Horizontes del relato. Lecturas y conversaciones con Paul Ricour. Madrid: Cuaderno Gris, 2001.

Basombrío, Manuel A. De la filosofía del yo a la bermenéutica del sí mismo: un recorrido a través de la obra de Paul Ricour. Málaga: Universidad de Málaga, 2008.

Calvo Martínez, T. y Ávila Crespo R., (eds.), Paul Ricœur: Los caminos de la interpretación. Symposium internacional sobre el pensamiento filosófico de Paul Ricœur. Granada, 23-27 de noviembre de 1987. Barcelona: Anthropos. 1991.

Conill, J. Ética hermenéutica. Madrid: Tecnos, 2006.

Díaz, C. y Maceiras, M. Introducción al personalismo actual. Madrid: Gredos, 1975.

Domingo Moratalla, T. Creatividad, ética y ontología. La fenomenología hermenéutica de P. Ricour. Madrid: Universidad Pontifica de Comillas, 1996.

Etxebarría Mauleón, X. Imaginario y derechos humanos desde Paul Ricœur. Bilbao: Desclee de Brouwer, 1995.

Fidalgo Benayas, Leonidas. Hermenéutica y existencia humanas. El pensamiento de Paul Ricour. Valladolid: Universidad de Valladolid, 1996.

Gadamer, H-G. (ed.), Das Problem der Sprache. Achter deutscher Kongress für Philosophie. Munich: Wilhelm Fink Verlag, 1966.

García Lozano, F. J. Los caminos de la acción. Un recorrido a través de la obra de Paul Ricœur. Murcia: Editorial Espigas, 2015.

Grondin, J. Introducción a la bermenéutica filosófica. Madrid: Herder, 1999.

Lanceros, P. La herida trágica. Barcelona: Anthropos, 1997.

Lledó, E. El surco del tiempo. Barcelona: Crítica, 1992. 
Maceiras, M. "Ricœur, Paul”. Diccionario de filosofía contemporánea. Salamanca: Sígueme, 1976.

Maceiras, M., y Trebolle, J. La hermenéutica contemporánea. Madrid: Ediciones Pedagógicas, 2004.

Mindán, M. "Recensión. Le volontaire et 1'involontaire". Revista de Filosofía 13 (1954): 340-344.

Martínez Sánchez, A. "Recepción de Paul Ricœur en español: bibliografía en castellano." Ideas y Valores 127 (2005): 73-98.

Marías, J. Los españoles. Madrid: Revista de Occidente, 1963.

Masiá Clavel J., Domingo Moratalla, T. y T. Ochaita, A. Lecturas de Paul Ricœur. Madrid: Universidad Pontificia de Comillas, 1998.

Mora García, J. L., Manzanero, D., González, M., Agenjo Bullón, X., (eds.), Crisis de la Modernidad y Filosofías Ibéricas. X Jornadas Internacionales de Hispanismo Filosófico. Madrid: Fundación Ignacio Larramendi, 2013.

Ortega y Gasset, J. El tema de nuestro tiempo, en Obras Completas, vol. III. Madrid: Alianza Editorial, 1983.

Ortiz-Osés, A. Las claves simbólicas de nuestra cultura. Barcelona: Anthropos, 1993.

—. A. Amor y sentido. Una hermenéutica simbólica. Barcelona: Anthropos, 2003.

Ortiz-Osés, A. y Lanceros P. (eds.), Diccionario de hermenéutica. Bilbao: Universidad de Deusto, 2004.

Ortiz-Osés, A. y Lanceros P. (eds.), Claves de Hermenéutica. Para la cultura, la filosofía y la sociedad. Bilbao: Universidad de Deusto, 2005.

Pannikar, R. Mito, fe y hermenéutica. Barcelona: Herder, 2007.

Peñalver, M. "Ricœur: la forma del sentido." Paul Ricœur. Discurso filosófico y bermeneusis, Revista Anthropos 18 (1998): 83.

Peñalver, M. La búsqueda del sentido en el pensamiento de P. Ricour. Sevilla: Publicaciones de la Universidad de Sevilla, 1978.

Picontó Novales, T. Hermenéutica, argumentación y justicia en Paul Ricour. Madrid: Editorial Dykinson, 2005.

Pintor Ramos, A. "Paul Ricœur y el estructuralismo." Pensamiento 31 (1975): 95-123 .

—_. "Paul Ricœur, fenomenólogo." Cuadernos salamantinos de filosofía 6 (1981): 135-156.

Recas Bayón, J. Hacia una hermenéutica crítica. Gadamer, Habermas, Apel, Vattimo, Rorty, Derrida y Ricour. Madrid: Biblioteca Nueva, 2006.

Schökel, L. A. Apuntes de hermenéutica. Madrid: Trotta, 1994.

Rodríguez Buil, Francisco Javier. Antropología de la alienación según la filosofía del sujeto de Paul Ricœur. Madrid: Fundación Universitaria Española, 2003.

Tell, María Belén. Tras la huella del testimonio. Estudio filosófico sobre los silenciosos alcances de la antropología hermenéutica de Paul Ricour. Salamanca: Universidad de Salamanca 2015. 
Trevijano Echevarría, P. "La dimensión horizontal de la esperanza en el pensamiento de Paul Ricœur." Scriptorium Victoriense 19 (1972): 5-34; "La dimensión vertical de la esperanza en el pensamiento de Paul Ricœur." Scriptorium Victoriense 19 (1972): 185-215.

Vansina, F. V. Paul Ricour. Bibliography 1935-2008. Lovaina: Leuven University Press, 2008.

Vattimo, G. Ética de la interpretación. Barcelona: Paidós, 1991.

Waldenfels, B. "Finitud y culpabilidad" (recensión). Documentación Critica Iberoamericana de Filosofía y Ciencia Afines 2 (1965): 63-7. 



\section{A RECEÇÃO DO PENSAMENTO H ISTÓRICO DE RICAEUR NA HISTORIOGRAFIA PORTUGUESA: FÁtima BONIFÁCIO E FERNANDO CATROGA}

THE RECEPTION OF RICAEUR'S HISTORICAL THOUGHT in PORTUGUESE Historiography: FÁtima Bonifácio AND FERNANDO CATROGA

Martinho Soares Univ. Católica do Porto/CECH, Univ. de Coimbra ${ }^{1}$

Resumo: Neste estudo damos conta da receção do pensamento histórico-filosófico de Paul Ricœur em Portugal, designadamente em dois notáveis historiadores e epistemólogos da ciência histórica: Fátima Bonifácio e Fernando Catroga. O texto apresenta-se dividido em três secções principais. Depois de uma breve introdução, a primeira parte permite uma abordagem sucinta ao lugar da história na obra filosófica de Ricœur, as grandes problemáticas que perpassam pelos seus escritos e o seu impacto na epistemologia da história. A segunda secção consiste numa análise crítica à receção das meditações ricœurianas em torno do caráter narrativo da história na obra de

${ }^{1}$ Martinho Soares, Universidade Católica Portuguesa, Faculdade de Teologia, Rua Diogo Botelho 1327, 4169-005, Porto, Portugal. / CECH, Instituto de Estudos Clássicos, Largo da Porta Férrea, 3004-530 Coimbra, Portugal. Mail: martinhosoares@ gmail.com 
Fátima Bonifácio Apologia da História Política. A historiadora socorre-se da obra Temps et Récit sobretudo para escorar a sua apologia da história política. Independentemente da legitimidade da sua opção historiográfica, denotamos uma leitura parcial e conveniente. A terceira secção é dedicada à assimilação e transmissão do pensamento histórico ricœuriano em várias obras e artigos de teoria histórica da autoria de Fernando Catroga, leitor assíduo do filósofo francês. Concluímos confrontando a forma como os dois autores recebem e empregam a hermenêutica histórica de Paul Ricœur.

Palavras-chave: Fátima Bonifácio; Fernando Catroga; história; narrativa; Ricour.

Abstract: In this paper we give an account of the reception of the historical and philosophical thought of Paul Ricour in Portugal, namely in two conspicuous historians and epistemologists of the historical science: Fátima Bonifácio e Fernando Catroga. The text is divided into three main sections. After a short introduction, the first section gives one brief approach to the place of history in the Ricoeur's philosophical work, the main issues of their writings, and their impact in the epistemology of history. The second section consists in the critical analysis of the reception of Ricœur's thought concerning the link between narrative and history in Fátima Bonifácio's work Apology of the Political History. The Portuguese historian relies on Time and Narrative mostly to support her apology for the political history. The legitimacy of her historiographical option notwithstanding, we find this reading to be partial and convenient. The third section is devoted to the assimilation and transmission of Ricour's historical thought by Fernando Catroga in his many works and papers concerning historical theory. Catroga is a frequent reader of the French philosopher. 
We conclude by comparing the way the two authors receive and employ Paul Ricour's historical hermeneutics.

Keywords: Fátima Bonifácio; Fernando Catroga; history; narrative; Ricour.

\section{Introdução}

Não abundam em Portugal reflexões de caráter epistemológico sobre a ciência histórica. É, aliás, muito raro que os historiadores portugueses se consagrem a este tipo de meditações auto ou metarreflexivas sobre as suas práticas historiográficas, preferindo seguir escolas ou correntes vindas de fora, sobretudo de França, e as suas fundamentações metodológicas implícitas. ${ }^{2}$ Dentre o reduzido número dos que se devotam a esta tarefa mais filosófica do que histórica, sobressaem os dois intelectuais em foco neste capítulo: Fátima Bonifácio e Fernando Catroga. Fátima Bonifácio, porque entende ser seu dever justificar a escolha de um objeto e modo de estudo historiográfico que havia sido menosprezado, se

2 A despeito desta carência, existem alguns trabalhos dignos de menção. Salientamos o périplo cronológico da ciência histórica em Portugal ao longo dos séculos XIX e XX em Luís Reis Torgal, José Amado Mendes, e Fernando Catroga, História da História em Portugal. Sécs. XIX-XX, 2 vols., (Lisboa: Temas e debates, 1998). Com discursos genuinamente meta-históricos sobre o ofício do historiador ou que abordam questões de natureza epistemológica, apresentamos alguns títulos: Joaquim Barradas de Carvalho, Da História-Crónica à História-Ciência (Lisboa: Livros Horizonte, 1972); José M. Amado Mendes, A história como ciência: fontes, metodologia e teorização (Coimbra: Coimbra Editora, 1987); José Mattoso, A escrita da História. Teoria e métodos. (Lisboa: Editorial Estampa, 1997); Luís Reis Torgal "História, divulgação e ficção", in Luís Reis Torgal, José Amado Mendes, e Fernando Catroga, História da História em Portugal. Sécs. XIX-XX, vol. 2, (Lisboa: Temas e debates, 1998), 155-219; José Augusto França, História, que história? (Lisboa: Colibri, 1999); Rui Bebiano, "Sobre a história como poética", in José d'Encarnação (org.), As oficinas da história. (Lisboa: Colibri, 2000), 47-70. Para além disto, é de saudar vivamente a criação recente da primeira revista nacional dedicada a questões da natureza metodológica e epistemológica no âmbito historiográfico: revista online Práticas da História, in http://www.praticasdahistoria.pt/pt/. Já publicado o n. ${ }^{\circ} 1$ (2015), consultado a 29-01-2016. 
não mesmo repudiado, pelas grandes correntes historiográficas do século XX, incluindo no nosso país, e pugnar pela sua reabilitação. Falamos obviamente da história política ou factual, que ocupou quase todo o campo da historiografia até às primeiras décadas do século XX. Fernando Catroga, porque soma ao ofício de historiador o de pensador e teorizador da ciência histórica, por via da sua função de docente, tendo publicado vários livros sobre esta matéria. Como historiador, está mais próximo da Nova História francesa e do estudo das Ideias, embora não despreze nas suas investigações o facto político ou o modo narrativo, podendo, em coerência com a dialética ricœuriana, articular acontecimentos breves com estruturas de longa duração, para descrever, por exemplo, os costumes sociais relacionados com o culto tanatológico. ${ }^{3}$

Sobre a receção do pensamento e da obra de Paul Ricœur em Portugal, podemos dizer que não se fica atrás da de outros grandes filósofos da contemporaneidade, merecendo uma atenção considerável quer por parte da comunidade académica e científica portuguesa quer por parte do público instruído. Para isso concorre, grandemente, o facto de a sua obra ser extensa e polimática, fruto dos múltiplos diálogos que o filósofo foi capaz de estabelecer com outras ciências humanas e sociais. De facto, as teses de Ricœur encontram hoje admiradores em áreas do saber tão diversas, ou afinal tão complementares, como a Filosofia, o Direito, os Estudos Literários, a Psicologia e a Psicanálise, a História, a Teologia, a Ética e a Bioética, entre outras. Curiosamente, com uma pluralidade de assuntos tão profícua e ampla, um dos temas que menos eco tem tido na comunidade lusa é justamente o da hermenêutica histórica; ${ }^{4}$ isto a despeito

\footnotetext{
${ }^{3}$ Fernando Catroga, O Céu da memória. Cemitério romântico e culto dos mortos. (Coimbra: Minerva, 1999).

${ }^{4}$ Apresentámos em 2011, à Universidade de Coimbra, uma tese de doutoramento dedicada à análise crítica das reflexões de Ricœur sobre o tema da historiografia. Esta deu origem ao seguinte volume: Martinho Soares, História e Ficção em Paul
} 
de o filósofo, como adiante veremos, ter dado a esta questão um lugar de não pouca relevância, como se pode comprovar pela bibliografia publicada. Pensamos que os motivos desta fraca adesão estão justamente relacionados com a escassa produção epistemológica que acima denunciámos. Por força desta omissão, ganham ainda mais importância os preciosos contributos de Bonifácio e Catroga, que aqui nos propomos analisar, com a vantagem de serem ambos assimiladores da hermenêutica ricœuriana.

\section{I - O lugar da história na obra filosófica de Paul Ricœur}

Les historiens savent la dette qu'ils ont envers Paul Ricour... Le livre de Ricœur les a aidés à être plus lucides sur leur propre pratique et à comprendre comment l'intention de vérité qui fonde leur discipline ne pouvait être séparée des parentés qui lient son écriture à celle des récits de fiction. ${ }^{5}$

Paul Ricœur está entre os filósofos que na segunda metade do século XX mais se debruçou sobre questões de natureza histórico-epistemológica, com o intuito determinado de encontrar um lugar firme para a história entre as ciências sociais. Com esse fito, enfrentou as correntes e ideologias que puseram em causa o seu estatuto científico, a sua qualidade narrativa e até o seu valor ético: o

Ricœur e Tucídides. (Porto: Fundação Eng. António de Almeida, 2014). Ainda dentro desta temática, temos proferido diversas comunicações e publicámos: «Ekphrasis e enargeia na historiografia de Tucídides e no pensamento filosófico de Paul Ricœur», Talia Dixit 6 (2011). http://www1.unex.es/arengas/taliadixit6.htm

5 Roger Chartier, "Le passé au présent", in Le Débat 122 (2002): 4. Sobre o impacto das teses de Ricœur na historiografia francesa veja-se C. Delacroix, F. Dosse, P. Garcia, Les courants historiques en France, (Paris: Gallimard, 2007), 587-588. 
narrativismo e o estruturalismo, o positivismo lógico, o negacionismo. É inegável que a história ocupa um lugar de destaque na economia do pensamento ricœuriano. Para além de significativo número de artigos e ensaios, contam-se cinco obras com a hermenêutica histórica em destaque: Histoire et vérité (1955), Temps et récit I e III (1983 e 1985), Du texte à l'action: Essais d'herméneutique II (1986), La mémoire, l'histoire, l'oubli (2000).

Numa entrevista publicada na revista Esprit, em 1981, pouco antes do lançamento do primeiro volume de Temps et récit, Paul Ricœur justifica a sua opção pela história com três razões de ordem essencial e várias de ordem técnica. ${ }^{6}$

Em primeiro lugar, considera que não é possível uma filosofia sem diálogo com as ciências humanas e que a história ocupa um lugar fundamental no concerto das ciências humanas. Em seguida, afirma que não há conhecimento de si que não se efetue através do desvio por sinais, símbolos e obras culturais; entre estas obras culturais encontram-se de forma permanente as histórias que contamos e que o historiador escreve. Por fim, sublinha a necessidade de preservar a diversidade das formas de linguagem existentes - a Ricœur interessava, sobretudo, nesta altura, o caráter narrativo do ato de contar histórias, em ordem a uma poética do tempo.

As razões de ordem técnica prendem-se com várias questões interligadas. Desde logo, o desejo de superar a subdivisão paradoxal do ato de narrar entre história e ficção. Não haverá um fator de convergência, de unidade? Para Ricœur, a intriga é o elemento comum que une os dois géneros narrativos. Em segundo lugar, pareceu-lhe que este ato narrativo unificador tem uma relação privilegiada com a experiência humana do tempo, porquanto esta não é redutível ao tempo cronológico marcado pelos relógios. Daqui surge a bifurcação

\footnotetext{
${ }^{6}$ P. Kemp e F. Marchetti (redação), "L'histoire comme récit et comme pratique. Entretien avec Paul Ricœur", in Esprit 54 (1981):155-165.
} 
entre tempo cronológico e tempo histórico; se o segundo é o meio através do qual nós narramos, conclui-se o seguinte: "O caráter narrativo da experiência do tempo seria pois uma espécie de teste para articular filosoficamente a estrutura do tempo, o que sempre foi tido como um dos grandes problemas da filosofia". 7 Contra a opacidade e mudez da experiência temporal, Ricœur propõe a loquacidade da narrativa, que serve como uma "espécie de janela aberta sobre o que é o tempo humano". ${ }^{8}$

Finalmente, há ainda razões de uma terceira ordem, secundárias do ponto de vista filosófico mas centrais do ponto de vista das suas convicções pessoais. Ricœur recorda "o caráter essencialmente narrativo da fé bíblica, que, antes de se exprimir em dogmas, em expressões abstratas sobre Deus, se apoia em histórias contadas: a história do Êxodo, a história da Crucificação e da Ressurreição, a história do Pentecostes, da Igreja primitiva ...". ${ }^{9} \mathrm{O}$ ato narrativo possui, por conseguinte, uma dimensão religiosa que poderá estar relacionada com o potencial da narrativa para estruturar o tempo. Todavia, antes desta dimensão religiosa, existe uma dimensão ética na narrativa. Nenhuma existência pode viver sem história, nenhuma consciência humana é autotransparente ou autoposicional, porque toda a experiência está imbuída de temporalidade, e ninguém se pode conhecer a si próprio sem ser por intermédio das narrativas que conta sobre si, o que leva a falar de uma função identitária pessoal e comunitária da narrativa. ${ }^{10}$

\footnotetext{
${ }^{7}$ Idem, op. cit., 156 [tradução nossa].

8 Ibid.

9 Ibid.
}

10 “... notre propre existence est inséparable du récit que nous pouvons faire de nous-mêmes: les histoires, vraies ou fausses d'ailleurs - peu importe ! -, les fictions aussi bien que les histoires exactes, disons vérifiables, ont cette valeur de nous donner une identité. ... Si l'on applique cette idée au champ religieux, on peu dire qu'Israël a constitué son identité en racontant sa propre histoire. Certains auteurs ont même appelé la Bible l'autobiographie d'Israël. Et, en ce sens, on peut dire qu'une tradition religieuse se caractérise d'abord par les histoires qu'elle raconte 
Talvez não seja possível identificar um tema que possa unificar a ampla e heterogénea bibliografia ricouriana sobre a temática histórica, que conta com as obras axiais já referidas e uma panóplia de artigos, comunicações, entrevistas e ensaios dispersos por revistas, livros, enciclopédias e atas de colóquios. No âmbito da reflexão epistemológica, um dos tópicos mais recorrentes é a dialética explicação-compreensão, sob a qual se discute a relação da história com a ciência e a narrativa, e daí com o tempo, a memória e a ficção. $\mathrm{Na}$ área da reflexão hermenêutica, da ontologia e da filosofia da história, os escritos de Paul Ricœur versam sobre o sentido da história, da consciência histórica e da condição histórica do homem, da memória e do esquecimento. No entanto, parece-nos que a preocupação maior do autor nesta matéria como, de um modo geral, em toda a sua produção filosófica tem como cerne a compreensão do homem no seu meio a partir da sua ação: o que é o homem, o que (e de que forma) as "praxeis" culturais humanas (muito particularmente as mediadas pela linguagem simbólica-metafórica-narrativa) nos podem revelar acerca do agente e do paciente humano? Em última análise, é sempre o mistério do homem temporal, agente, falível e sofredor que o filósofo procura iluminar através da análise semântica dos elos simbólicos que medeiam a nossa relação com o mundo e connosco próprios. Neste processo interpretativo, as narrativas ocupam um lugar cimeiro: a narrativa diz de forma indireta (poética), mas significativa, o homem concreto e a realidade que o envolve. Ricour parte da constatação de que o homem vive enredado em histórias, procura conhecer-se e dar-se a conhecer através delas.

Compreende-se, pois, que a história - sendo, de um modo específico, uma narrativa e, além do mais, uma narrativa que visa relatar factos verdadeiros, comprováveis - ocupe um lugar central nesta

et, bien entendu aussi, par les interprétations symboliques ou autres qu'elle greffe sur ces histoires. Mais le premier noyau est un noyau narratif" (Ibid.). 
dinâmica. Que a história é uma narrativa comprova-o a própria ambiguidade do termo que na maior parte das línguas europeias significa, simultaneamente, o que realmente aconteceu no passado (dimensão ontológica do termo) e o discurso que sobre isso se faz (dimensão epistemológica do termo). ${ }^{11}$ Ricour acredita que esta ambiguidade semântica não acontece por acaso, contribuindo para reforçar a similitude entre o ato de narrar a história e o estar na história, ou seja, entre fazer a história e ser histórico. Vai ainda mais longe ao destacar o papel que história e ficção desempenham na construção de narrativas que direta e indiretamente contribuem para desfazer a opacidade da experiência humana. ${ }^{12}$ De facto, as histórias e a história são fautoras de historicidade humana. ${ }^{13}$ A polissemia da palavra história serve para recuperar o papel da narrativa na história, depois de um período de eclipse, ${ }^{14}$ obrigando o historiador a interrogar-se sobre o seu ato de escrita, sobre a proximidade deste com a ficção e ainda sobre a fronteira que os separa. ${ }^{15}$ Apesar de

11 Paul Ricœur, "Pour une théorie du discours narratif", in La narrativité, ed. D. Tiffeneau (Paris: Ed. du CNRS, 1980), 58.

12 “... la prétention référentielle indirecte des récits de fiction et la prétention référentielle directe des récits historiques (en tant qu'histoire 'vraie', au sens épistémologique du mot 'vrai')" (Ibid., 58)

13 "Cette opacité logique peut expliquer que l'historicité de l'expérience humaine ne puisse être portée au langage que comme narrativité, - et que cette narrativité elle-même ne requière pas moins que le jeu et l'intersection des deux grands modes narratifs. L'historicité est dite, dans la mesure où nous racontons des histoires et écrivons l'histoire." (Ibid., 59).

${ }_{14}$ Paul Ricœur, Temps et récit I: L'intrigue et le récit historique, (Paris : Seuil, 1983), 171-216: "L'éclipse du récit".

15 "Après une longue éclipse du récit au cours de laquelle les historiens du $\mathrm{XIX}^{\mathrm{e}}$ et $\mathrm{du} \mathrm{XX}^{\mathrm{e}}$ siècle ont cru pouvoir fonder une physique sociale, croyant rompre à jamais avec l'histoire-récit, les historiens aujourd'hui insistent au contraire sur le fait que la notion d'histoire revêt une valeur polysémique, désignant tout à la fois l'action narrée et la narration elle-même, confondant tout ainsi l'action d'un narrateur, qui n'est pas forcément l'auteur, avec l'objet du récit. L'historien est de nouveau invité à s'interroger sur son acte d'écriture, sur la proximité de celui-ci avec l'écriture fictionnelle et en même temps sur la frontière qui distingue les deux domaines". (François Dosse, "Le moment Ricœur de l'opération historiographique", Vingtième siècle, Revue d'histoire 69 (2001): 87). 
reconhecer essa polissemia do termo história, que tanto pode significar história como histórias, o filósofo francês acentua as diferenças que separam a história das narrativas ficcionais, nomeadamente no que à pretensão à verdade diz respeito. É que a imaginação não está confrontada com as mesmas exigências críticas e científicas da história, sendo que esta se pauta pela realidade dos documentos e dos arquivos. ${ }^{16}$

A suspeita de que a história não é totalmente verdadeira porque está enredada na ficção nasceu com a própria história e acompanhou-a ao longo dos séculos. Contudo, foi a partir do século XIX, com o eclodir da chamada história científica (epifenómeno do hegemónico e otimista modelo positivista), que a questão se agudizou e ganhou novos contornos. Para a história exigiu-se o mesmo tipo de método e resultados que as ciências físicas e biológicas almejam (Montesquieu, Voltaire, Condorcet). No entanto, a conclusão de que a lei e a causa positivista não estavam ao alcance da história não fez os historiadores arredarem pé da senda das ciências, já não das naturais mas das sociais e humanas. Enquanto teóricos narrativistas e estruturalistas tentaram aproximar a história da narrativa, acentuando a sua dimensão de artefacto literário, sujeito ao relativismo de todo o discurso ficcional, os historiadores franceses da entourage dos Annales e os teóricos do modelo nomológico procuraram afastar a

16 "Je n'ai aucunement l'intention de nier ou d'obscurcir les différences évidentes qui séparent l'histoire de l'ensemble des récits de fiction quant à leur prétention respective à la vérité. Pour un certain niveau d'analyse et d'argumentation, le concept conventionnel de vérité, défini en termes de vérification et de falsification empiriques, est parfaitement valide. ... la vérification ou la falsification en histoire ne met pas en jeu un concept de vérité différent de celui que la physique assume. Documents et archives sont les sources de vérification et de falsification pour l'investigation historique. Les récits de fiction, d'autre part, ignorent la charge de fournir des preuves de cette sorte.... il reste que l'imagination ignore le dur labeur de se confronter à des documents et même de les établir en fonction des questions qui leur sont posées. En ce sens l'imagination n'a pas de 'faits' à traiter". (Paul Ricœur, "Pour une théorie du discours narratif", in La narrativité, ed. D. Tiffeneau (Paris: Ed. du CNRS, 1980): 151). 
história da narrativa e do acontecimento breve, aproximando-a das ciências exatas. A história é confrontada com a alternativa de ser ciência idiográfica (compreensiva) ou ciência nomotética (explicativa), narrativa de acontecimentos singulares ou conjunto de proposições científicas que inscrevem factos sob leis gerais.

É neste cenário de real tensão que surgem as reflexões de Ricœur. Homem atento às questões do seu tempo, leitor assíduo dos historiadores, contribuiu de forma determinante para uma conciliação. A sua grande vitória foi justamente a de ter conseguido congraçar dois conceitos aparentemente contraditórios sem retirar credibilidade e autoridade explicativa à história. Esta, apesar de recorrer à ficção para cativar o público leitor, para dar visibilidade aos factos narrados, em suma, para se dar a ler, continua a ter como alvo insubstituível a verdade. Não uma verdade de teor positivista (em que haveria coincidência entre o real e o conhecimento histórico), mas a verdade visada através da positividade do ter-sido e reconstruída sob o regime analógico da representância [représentance] ${ }^{17}$ Só assim a história mantém a capacidade para dar conta, de forma científica, de uma realidade exterior ao discurso, evitando cair no relativismo que os teóricos do linguistic turn alimentaram.

Atualmente, é relativamente pacífica entre historiadores e filósofos a admissão da componente ficcional da história em concomitância com a autonomia explicativa e científica da mesma. É reconhecido o contributo de Ricœur para este processo. ${ }^{18}$ A história é uma ciência,

\footnotetext{
17 Paul Ricœur, Temps et récit III : Le temps raconté, (Paris: Seuil, 1985), 252-283; Idem, La mémoire, l'histoire, l'oubli (Paris : Seuil, 2000), 359-369.

18 "Le tournant interprétatif adopté par les travaux actuels permet de ne pas se laisser enfermer dans la fausse alternative entre une scientificité qui renverrait à un schéma monocausal organisateur et une dérive esthétisante. Le basculement est particulièrement spectaculaire dans la discipline historique qui a été nourrie tout au long des années soixante et soixante-dix, sous l'impulsion de l'école des Annales, d'un idéal scientiste, celui de trouver la vérité ultime au bout des courbes statistiques et des grands équilibres immobiles et quantifiés. Grâce au travail sur le temps de Paul Ricœur, on redécouvre la double dimension de l'histoire qui, sous
} 
ainda que não como as outras, e uma arte, ainda que diferente de todas as outras. ${ }^{19}$ A ficção, sabemo-lo, é do domínio da criação, da modelação, do recurso à imaginação; tem contacto com o mundo, mas não tem contrato com a verdade factual nem está obrigada a prestar provas das suas declarações. A opinião de Ricœur é de que a história, ainda que não possa dispensar a imaginação, a interpretação e a retórica, é um discurso que, por meio de um método científico e crítico, busca incessante e incansavelmente a verdade rigorosa dos factos que narra, nisso ocupando um espaço distinto do da ficção. O historiador estabelece implicitamente com o leitor um compromisso ético e profissional de verdade, que implica julgar/ explicar mediante a apresentação de provas. E, nesse sentido, a sua tarefa aproxima-se da do juiz. ${ }^{20}$

Começámos este estudo com uma epígrafe alusiva à dívida que os historiadores franceses sentem para com Ricœur, movidos pelas suas pertinentes e valiosas reflexões epistemológicas sobre a historiografia. É nosso intuito agora dar nota da forma como as teses da história de Paul Ricœur foram recebidas por historiadores portugueses, nomeadamente nos dois que mais longamente se detiveram e absorveram as suas lições.

le même vocable en France, recouvre à la fois la narration elle-même et l'action narrée". (François Dosse, L'histoire, (Paris: Armand Colin, 2001), 54-55). Vide também C. Delacroix, F. Dosse, P. Garcia, Les courants historiques en France (Paris: Gallimard, 2007), 587-588.

19 Vide Jacques Le Goff, "História", in Enciclopédia Einaudi, Vol. 1: Memória-História (Porto: INCM, 1984), 158-259.

${ }^{20}$ A comparação do historiador com o juiz é muito frequente em P. Ricœur. Para além de várias menções em Temps et Récit, o autor dedica uma análise mais demorada ao tema em La mémoire, l'histoire, l'oubli. (Paris: Seuil, 2000) - "L'historien et le juge": 413-436. O grande historiador Carlo Ginzburg publicou também um ensaio sobre o mesmo assunto: Il giudice e lo storico (Turin: Einaudi, 1991). 


\section{II - A apologia da história política em Fátima Bonifácio}

Apologia da História Politica é o nome do ensaio que abre a obra com o mesmo título de Fátima Bonifácio, publicada em 1999 pela editora Quetzal. O corpo do livro compreende ainda três estudos de história política do século XIX, ilustradores práticos da teoria antes exposta. A autora, reputada historiadora e professora universitária, foi uma das poucas figuras do Portugal contemporâneo a produzir reflexão epistemológica e metodológica sobre história política e narrativa, sendo nesse exercício recetora e comentadora da trilogia Temps et Récit de Paul Ricour, obra de que se socorre frequentemente para estribar a sua argumentação. O seu texto surge no seguimento de um pequeno artigo de viragem publicado na revista Análise Social XXVIII (1993-3. '): 623-630, com o título "O abençoado retorno da velha história".

A Apologia da História Política tem o seu propósito bem definido no título: pretende demonstrar a pertinência, a validade e a dignidade $^{21}$ da história política como campo de estudo e disciplina literária, tal como era praticada antes de ter sido banida pela história-ciência instaurada pela Escola dos Annales. Trata-se de legitimar a história política tradicional, também conhecida como metódica, evenemencial, ou de batalha, e os seus objetos de eleição: "a política, as grandes figuras, as instituições, a história do pensamento e das ideias, a diplomacia e as relações internacionais, a história militar e constitucional". ${ }^{22}$ Note-se que foi a contestação a estes objetos privilegiados da pesquisa histórica que conduziu a Escola dos Annales àquilo que Ricœur designou por "eclipse da narrativa", resultado do abandono da história política em função de novos objetos de estudo

${ }^{21}$ Fátima Bonifácio, Apologia da história política (Lisboa: Quetzal, 1999), 20.

22 Fátima Bonifácio, "O abençoado retorno da velha história”, in Análise Social XXVIII, (1993-3. $\left.{ }^{\circ}\right): 628$. 
e do alargamento do questionário a dimensões socioeconómicas, ligadas às massas sociais e já não a indivíduos particulares, a factos e a datas. ${ }^{23}$ Pois bem, Fátima Bonifácio pretende deseclipsar a narrativa, reinvestindo-a do seu estatuto científico objetivo e racional, configurador de identidades e ações humanas passadas, e afastar da narrativa histórica tudo o que sejam trends seculares, séries de preços, padrões demográficos, evoluções estruturais, modos de produção, isto é, a ciência social. Não que menospreze o valor destas informações, apenas as remete para o campo das Ciências Sociais.

A sua tese compreende um preâmbulo e três andamentos. No preâmbulo é bem patente a crítica severa à história estrutural e de longa-duração implementada por Braudel e seus seguidores. Lamenta-se a autora pela perda do sujeito, das ações humanas e dos acontecimentos que delas resultam como fonte de inteligibilidade histórica, para dar lugar às estruturas profundas do fenómeno social.

$\mathrm{Na}$ primeira parte do ensaio, analisa os impasses da história como ciência, tentando desmascarar as suas pretensões científicas de âmbito nomológico. O seu ataque dirige-se de modo particular à Escola dos Annales, desde a fundação à sua terceira vaga, a da chamada Nova História ou História das Mentalidades. Mantendo um registo por vezes irónico e retórico próprio da diatribe, a historiadora, mostrando-se muito segura e convicta na argumentação e bem apoiada nas provas bibliográficas, prossegue o seu libelo contra a história económica e social, estrutural e das ideias, acusando-a de ter erradicado do campo da historiografia a sua matriz fundadora e identitária, a história política, e a sua forma natural, a narrativa. O suposto retorno da "nova história política", objeto da segunda

23 Justamente, em Temps et Récit I (Paris: Seuil, 1983), 183-184, Ricœur observa que história política, história factual e história-narrativa foram tomadas como expressões quase sinónimas e critica este tratamento depreciativo da categoria narrativa da história como efeito secundário de uma reação violenta contra a história dita política, à qual foi associada a narrativa. 
parte do ensaio, não serve de desagravo nem de compensação, pois que esta dita "nova história política", na ótica da autora, nada tem de político, continuando a repudiar como insignificantes a narrativa, o acontecimento breve, os grandes homens. Em muitos casos - denuncia a mesma - "não se deixa distinguir de outras disciplinas das ciências sociais como a politologia, a semiótica e a sociologia". 24 Evocando os principais artigos impulsionadores dos "retornos", desde o célebre e liminar texto que Lawrence Stone deu à estampa em 1979, "The return of Narrative" 25 , também citado por Ricœur na página 312 de La mémoire, l'histoire, l'oubli, até às reflexões autocríticas da própria Escola dos Annales, conhecidas como tournant critique, ${ }^{26}$ a partir de finais da década de 80 , e apelando a um ressurgimento da narrativa, a autora pretende pôr a nu a falácia do retorno. Destaca o contributo de Roger Chartier, o qual, apoiando-se nas teses de Paul Ricœur expostas em Temps et Récit, tenta demonstrar, na esteira do filósofo francês, que a história não chegou a perder totalmente a sua ligação à narrativa. ${ }^{27} \mathrm{~A}$ autora discorda, considerando que esta suposta nova história narrativa está muito longe da narrativa clássica como a definiu Ricour, com base nas teses de Danto, a saber, um realinhamento retrospetivo de acontecimentos passados provocados por agentes humanos e interpretados pelo historiador à luz de acontecimentos ulteriores relacionados com os primeiros. ${ }^{28}$ No seu entender: "'a nova história narrativa' não conta uma história. A história da França de Zeldin, ou a história de Montaillou de

\footnotetext{
${ }^{24}$ Fátima Bonifácio, Apologia da história política (Lisboa: Quetzal, 1999), 35.

25 Lawrence Stone, "The return of Narrative", in Past \& Present 85 (1979): 116-142 .

26 Vide C. Delacroix, F. Dosse, P. Garcia, Les courants historiques en France (Paris: Gallimard, 2007), 516-517.

${ }^{27}$ Roger Chartier, "L'histoire aujourd'hui: doutes, défis, propositions", in $A$ história a debate vol. I, ed. Carlos Barros (Santiago de Compostela, 1995): 119-130.

${ }^{28}$ Fátima Bonifácio, Apologia da história política (Lisboa: Quetzal, 1999), 62. Cf. Paul Ricœur, Temps et Récit I (Paris: Seuil, 1983), 256-265.
} 
Ladurie, ou a história da morte de Ariés, ou a história do medo de Delumeau, não contam propriamente algo que reconheçamos como uma história - em alguns casos nem há história nenhuma”. ${ }^{29}$

Mesmo a micro-história, que Ricour, em La mémoire, l'bistoire, l'oubli (obra publicada posteriormente ao ensaio de Fátima Bonifácio), considera ter recuperado a narrativa para o campo da historiografia, não colhe as graças da historiadora, considerando esta que a mudança de escala de macro para micro e a fixação num indivíduo particular, representante de toda uma comunidade, época, ou ideologia, continua refém da descrição e do social.

No terceiro andamento do seu ensaio, a autora explica, com base maioritariamente nas teses de Ricœur, o que considera ser uma verdadeira história política narrativa. Começa por reestabelecer como núcleo fundamental da história a compreensão empática ou simpatia intuitiva prenunciada em Giambattista Vico, apropriada pelo historicismo alemão, com reflexos significativos na sociologia compreensiva de Max Weber e daí na obra do pensador e historiador francês Raymond Aron. Refazendo o percurso histórico-filosófico também percorrido por Ricœur em Temps et Récit, Fátima Bonifácio evoca o modelo nomológico da história, advogado por K. Popper e C. G. Hempel, e os seus críticos narrativistas, William Dray, Paul Veyne, Arthur Danto. Expondo o confronto entre as duas fações, coloca-se como seria expectável do lado dos narrativistas e dos defensores da sociologia compreensiva. Interessa-lhe sobremaneira fundamentar a compreensão narrativa e a imputação causal singular como método inteligível específico e único do discurso histórico, e logo da história política, a seu ver, a única possível e verdadeira. Em seu auxílio, convoca novamente a definição de história que Ricœur formula a partir do conceito de frase narrativa de Arthur Danto, a saber: "a história é uma descrição de acontecimentos anteriores sob

${ }^{29}$ Fátima Bonifácio, Apologia da bistória política (Lisboa: Quetzal, 1999), 62. 
a descrição de acontecimentos ulteriores, desconhecidos dos atores dos primeiros" ${ }^{30}$ Daí em diante toma o filósofo francês como o seu "principal guia", mas com as devidas ressalvas: "muito embora eu me guie a mim mesma num sentido diferente daquele em que ele [Ricour] pretende conduzir o leitor". ${ }^{31}$ A autora alude aqui ao facto de a reflexão de Ricœur se encaminhar para uma poética do tempo, investindo a narrativa histórica e ficcional como solução poética à aporia do tempo.

Bonifácio toma como ponto de partida a asserção ricœuriana de que entre a Nova História, mesmo a mais fundamentalista, e a narrativa existe um vínculo, seja ele ténue ou indireto, mas essencial para preservar o caráter propriamente histórico da história. Evoca, em seguida, a conhecida tese defendida por Ricœur da dimensão configurante da narrativa enquanto síntese do heterogéneo, relembrando a capacidade que esta tem de convocar em simultâneo causas heterogéneas e reuni-las num todo coeso e inteligível. Deste modo, a narrativa "dá-nos uma visão global dos acontecimentos, quer dizer, permite-nos 'apreendê-los juntos' através de uma espécie de 'juízo sinótico' que abarca, 'num único ato mental', coisas separadas no tempo e no espaço, e até separadas de um ponto de vista lógico". 32 Daqui passa a concluir que "a narrativa constitui a forma natural da explicação histórica, querendo com isso dizer que narrar e explicar se não distinguem". ${ }^{33}$ Acrescenta que Ricœur "vai ainda mais longe e afirma que 'uma narrativa que fracassa em explicar é menos do que uma narrativa'. Daí que explicar melhor consista simplesmente em narrar mais". ${ }^{34}$ Esta última afirmação, apresentada como corolário

\footnotetext{
30 Idem, op. cit., 110.

${ }^{31}$ Idem, op. cit., 115.

${ }^{32 I}$ dem, op. cit., 116.

33 Idem, op. cit., 120.

${ }^{34}$ Ibid.
} 
da sua argumentação, se pretende ser a tradução da famosa sentença "en expliquant plus on raconte mieux" 35 ou de uma sua similar que Ricœur colhe em Paul Veyne, "Expliquer plus c'est comprendre mieux"36 exige da nossa parte crítica e correção. Há uma divergência significativa entre o modo como Veyne e Bonifácio de um lado e Ricœur do outro entendem a asserção. Na verdade, nunca foi intenção de Ricœur considerar autossuficiente a explicação narrativa, a ponto de esta poder dispensar uma explicação de teor nomológico. De facto, Ricœur perfilha a ideia dos narrativistas de que narrar já é explicar. O famoso conceito aristotélico do "um por causa do outro" (di'allela), em vez de um a seguir ao outro, próprio da crónica, faz a conexão lógica de qualquer intriga. O filósofo francês também reconhece às teses narrativistas da história a virtude de chamar a atenção para o facto de a qualidade propriamente histórica da história só poder ser preservada por meio do elo que liga a explicação histórica à compreensão narrativa, contra a rutura epistemológica que pretendeu dissociá-las. Todavia, afasta-se dos narrativistas por estes contemplarem apenas as formas historiográficas com ligação direta e visível à narrativa, ignorando as transformações que a historiografia foi sofrendo ao longo do século XX; 37 ou por não conseguirem integrar a explicação através de leis no tecido narrativo da história. Esta crítica aplica-se perfeitamente ao ensaio de Fátima Bonifácio, o qual podemos classificar categoricamente de narrativista, defendendo a narrativa como única "estratégia de explicação na qual ficam subsumidas a teoria, a análise e a demonstração". ${ }^{38}$ Para a historiadora

\footnotetext{
35 Paul Ricour, Du text à l'action: Essais d'herméneutique II (Paris: Seuil, 1986), 15.

36 Paul Ricœur, Temps et Récit II (Paris: Seuil, 1984), 14. Cf. Paul Veyne, Comment on écrit l'bistoire, (Paris : Seuil, 1971), 132.

${ }^{37}$ Ricœur é desde o início muito assertivo e cauteloso nesta matéria: "ma thèse concernant le caractère ultimement narratif de l'histoire ne se confond aucunement avec la defense de l'histoire narrative" (Paul Ricœur, Temps et Récit I (Paris: Seuil, 1983), 165). O itálico é do próprio autor.
}

38 Fátima Bonifácio, Apologia da história política (Lisboa: Quetzal, 1999), 50. 
não há como conciliar narrativa e ciência nomotética. Alguns dos seus pares criticaram-na justamente por verem nesta sua Apologia o retorno da velha história política tal como se fazia em finais do século XIX. ${ }^{39}$ A própria não refutaria essa objeção. E embora conceda, na esteira de Ricour, que a narrativa histórica incorpore elementos heterogéneos de ordem estrutural, descritiva ou não evenemencial entre o relato dos acontecimentos, tal deve ser feito em proporção que não quebre a unidade dramática ou a coesão narrativa, aludindo aos preceitos que Aristóteles preconiza na Poética para o modelo trágico. ${ }^{40}$ Com estas restrições, torna-se muito difícil aceitar como narrativos a maioria dos trabalhos historiográficos produzidos ao longo do século XX até à atualidade, cuja natureza narrativa Ricœur nunca pôs em causa, embora tivesse considerado muitos no limiar da sociologia e em risco de apagar a identidade da história enquanto ciência social e humana autónoma.

O filósofo francês nunca pretendeu denegar o caráter científico da história nem excluí-la do campo das ciências sociais e humanas; pelo contrário, trabalhou no sentido de marcar a sua especificidade, pela sua ligação umbilical à narrativa e desta ao acontecimento temporal - peça fundamental sem a qual não existe narrativa. Este facto leva-o, como bem viu Fátima Bonifácio, a fazer uma revisão crítica do contributo da escola francesa dos Annales, da sua repugnância pelo acontecimento breve e, consequentemente, pela narrativa, bem como

\footnotetext{
39 Vide Luís Reis Torgal, José Amado Mendes, e Fernando Catroga, História da História em Portugal. Sécs. XIX-XX, vol. 2. (Lisboa: Temas e debates, 1998), 69. O seu colega historiador, Nuno Severiano Teixeira, também aborda a temática em "A história política na historiografia contemporânea", publicado na revista Ler História 13, (1998): 77-102. Não obstante, este procura conciliar a nova história política com a história social e a própria sociologia, uma solução inteiramente consentânea com a visão de Paul Ricœur, o qual defende que a compreensão histórica pode e deve recorrer às explicações científicas das outras ciências sociais, mais gerais mas irmãs, como a sociologia, a antropologia, a demografia, para aclarar os factos particulares por ela narrados.
}

40 Fátima Bonifácio, Apologia da história política (Lisboa: Quetzal, 1999), 125. 
do modelo nomológico, que tenta inscrever a história no círculo fechado das ciências exatas. É verdade que estas teorias da história conduziram ao abandono da história política e factual, substituída que foi por uma história de longa duração, tornada história social, económica, cultural, mas que, segundo Ricœur, permanece unida ao tempo e dá conta de acontecimentos que ligam uma situação inicial a uma situação final, pois não é a velocidade da mudança que faz a história. ${ }^{41}$

Neste sentido, um dos passos mais ousados e também mais admiráveis de Ricœur é a arguta e paciente análise da extensa obra histórica de F. Braudel, La Méditerranée et le Monde méditerranéen à l'époque de Philippe II (publicada em 1949), no intuito de fazer emergir da sua estrutura tripartida as características de uma intriga.

Ignorar a inteligibilidade de base da narrativa (a sua capacidade configuradora) impede de compreender como é que a explicação histórica se pode coadunar com a compreensão narrativa, de maneira que: "en expliquant plus on raconte mieux". ${ }^{42}$ É este famoso adágio que nos oferece como solução à antinomia explicação-compreensão. Ele serve de divisa aos estudos desenvolvidos pelo autor em Temps et récit I e II, onde se trata de ligar explicação e compreensão ao nível, respetivamente, da historiografia e da ficção, mas assoma já nos estudos hermenêuticos que encontramos reunidos em $D u$ texte à l'action: Essais d'herméneutique II. Apesar de as análises de

41 "La vitesse du changement ne fait rien à l'affaire. En restant liée au temps et au changement, elle reste liée à l'action des hommes qui, selon le mot de Marx, font l'histoire dans des circonstances qu'ils n'ont pas faites. Directement ou indirectement, l'histoire est celle des hommes qui sont les porteurs, les agents et les victimes des forces, des institutions, des fonctions, des structures dans lesquelles ils sont insérés. A titre ultime, l'histoire ne peut rompre tout à fait avec le récit, parce qu'elle ne peut rompre avec l'action qui implique des agents, des buts, des circonstances, des interactions et des résultats voulus et non voulus. Or l'intrigue est l'unité narrative de base qui compose ces ingrédients hétérogènes dans une totalité intelligible". (Paul Ricœur, Du texte à l'action: Essais d'herméneutique II (Paris: Seuil, 1986), 15).

42 Ibid. 
Temps et récit serem mais detalhadas, ambas as obras convergem na finalidade. No que à história diz respeito, Ricœur não nega que esta possa recorrer a leis, que pode pedir emprestadas a outras ciências sociais mais sofisticadas como a demografia, a economia, a linguística, a sociologia ou que a explicação histórica possa ser constituída por leis, causas regulares, funções, estruturas; questiona, sim, o seu funcionamento, o facto de não funcionarem em história da mesma maneira que funcionam nas ciências da natureza, e terem de se articular necessariamente com a compreensão narrativa que lhes subjaz. As leis só por si não têm significado histórico, para o adquirirem têm de estar inseridas numa narração de acontecimentos aos quais se referem, pois é a compreensão narrativa que preserva o caráter irredutivelmente histórico da história. De facto, observa Ricœur, o historiador não estabelece as leis, utiliza-as. ${ }^{43}$

Esta dialética entre compreensão e explicação é ignorada por Fátima Bonifácio, essencialmente - podemos conjeturar nós - porque a sua aceitação inviabilizaria o seu dogmatismo narrativista e político, que pretende fazer à ciência social o que a Escola dos Annales fez à narrativa. Do mesmo modo que a história estrutural socioeconómica francesa entendeu erradicar da escrita historiográfica qualquer intriga, para a transformar numa sequência de dados científicos, a mais das vezes quantitativos, também Bonifácio pretende expurgar da história política todo o dado científico geral, proveniente das outras ciências sociais, porquanto afetaria a unidade narrativa, entendida esta no seu sentido clássico, promanado da Poética aristotélica. No fundo, a grande preocupação de Bonifácio consiste na preservação a qualquer custo da narrativa e da intriga histórica tradicionais. Compreende-se, por conseguinte, a preferência pelo facto político-militar, o único passível de uma configuração narra-

43 Paul Ricour, "Pour une théorie du discours narratif", in La narrativité, ed. D. Tiffeneau (Paris: Ed. du CNRS, 1980), 7. 
tiva linear. Esta posição estremada vai contra o espírito dialético e conciliador de Ricœur. No entanto, a mesma dialética encontra noutro historiador e académico português um bom acolhimento, de que falaremos a seguir.

\section{III - Ricour lido por Fernando Catroga}

Fernando Catroga é um historiador e destacado pensador da teoria da história, conjugando o ofício de investigador e divulgador de História das Ideias, da Cultura e das Mentalidades com o de professor de Teoria da História e do Conhecimento Histórico, na Faculdade de Letras da Universidade de Coimbra. Autor de várias obras historiográficas e outras tantas de filosofias da história e da memória, é nestas últimas que o pensamento histórico-filosófico de Ricœur assoma de forma bastante significativa, demonstrando o quanto o historiador conimbricense é um leitor atento do filósofo francês. Também nas suas aulas o nome de Ricœur é frequentemente invocado, como se pode comprovar no texto das suas provas de agregação, relatório curricular da cadeira que leciona. ${ }^{44}$

Memória, História e Historiografia, opúsculo dado ao prelo em 2001, resulta da compilação de três notáveis ensaios: "Recordação e esquecimento"; "Memória e historiografia"; e o terceiro, muito breve, "Comemoração e poder". Ricœur é presença assídua ao longo de todo o primeiro e segundo ensaios entre outros destacáveis teorizadores da memória, alguns destes citados a partir da obra do filósofo francês. Dele menciona Catroga vários artigos e a obra La Mémoire, l'histoire, l'oubli, publicada pouco antes do seu livro. Os artigos de Ricœur, no total de quatro, surgiram inicialmente em várias revistas

${ }^{44}$ Fernando Catroga, Teoria da História e do Conbecimento Histórico - Relatório, Universidade de Coimbra, Faculdade de Letras, 1996 (edição policopiada). 
em França e em Espanha, e constituem textos embrionários das teses expostas posteriormente em La mémoire, l'histoire, l'oubli, acabando por se incorporarem de forma diluída na própria obra. ${ }^{45}$

Os passos do homem como restolho do tempo. Memória e fim do fim da história, publicado em 2009, em edição da Almedina, retoma os três ensaios referidos, em versão revista e aumentada, aos quais se juntam uma série de outros estudos, alguns reconduzidos a partir de revistas, outros da obra anterior, Caminhos do Fim da História (2003). ${ }^{46} \mathrm{Em}$ boa verdade, o volume de 2009 funciona como uma espécie de ponto de chegada de todo um percurso académico e intelectual consagrado à reflexão historiográfica. A influência de Ricœur é aqui notória, servindo as suas próprias ideias bem como a de outros autores reunidos de forma eclética nos seus textos, como Halbwachs, Bergson, M. de Certeau, F. Hartog, R. Koselleck, Santo Agostinho, Aristóteles e Platão ou que refletiram sobre e com base na sua obra, casos de Jeffrey Barash e François Dosse. Todos encontram em Catroga uma autêntica caixa-de-ressonância, que não se limita, muito longe disso, à mera paráfrase. Tendo como pano de fundo o trabalho intelectual destes e de outros como M. Augé, Le Goff, S. Mosès, I. Berlin, H. Arendt, T. Todorov, W. Benjamin, M. Bloch, Durkheim, Hegel, Catroga expõe as suas, por vezes, intrincadas leituras com perspicácia e originalidade, não se limitando

45 São eles: "Entre mémoire et histoire", Projet 248 (1996): 7-16; "Vulnerabilité de la mémoire", in Patrimoine et passions identitaires. Entretiens du patrimoine. Théâtre National de Chaïlot, Paris, 6, 7 et 8 Janvier, 1997, ed. Jacques Le Goff et al., (Paris: Fayard, 1998); La Lectura del tiempo passado: memoria y olvido, (Madrid: Ediciones de la Universidad Autonoma de Madrid, 1998); "Un parcours philosophique", in Magazin Littéraire 390, (Septembre, 2000).

${ }^{46}$ Fernando Catroga, Caminhos do Fim da história, (Coimbra: Quarteto, 2003). Nesta obra há apenas esparsas referências explícitas a Ricœur, mas adivinha-se muitas vezes o seu pensamento em pano de fundo, nomeadamente quando o autor aborda as temáticas do tempo, ou a relação entre história e ciência, a partir da dialética compreensão/explicação. A demonstrar a influência de Ricœur está o facto de o autor citar-lhe várias obras na bibliografia final: Temps et récit, 3 vols.; La mémoire, l'bistoire, l'oubli e La lectura del tiempo passado. Memoria y olvido. 
ao exposto pelo filósofo francês, mas demonstrando uma aptidão muito ricœuriana de pôr em diálogo à volta do mesmo assunto uma plêiade intelectual assaz heterogénea, quer nas ideias quer nas áreas científicas.

A figura tutelar de Ricœur é particularmente relevante nas duas primeiras partes da obra, onde se reflete acerca de memória, historiografia, morte, tempo, alteridade e epistemologia. A obra de referência continua a ser La mémoire, l'histoire, l'oubli, mas à colação vêm também Histoire et vérité, a trilogia Temps et récit $\mathrm{e}$ os artigos já referidos anteriormente. ${ }^{47} \mathrm{O}$ autor recupera temas ricœurianos como a dialética entre recordação e esquecimento, as teorias platónica e aristotélica sobre a memória como representação (eikon) do passado, o binómio aristotélico mneme e anamnesis, o traço como testemunho e indício e a relação destes com o documento, a importância do questionário, a memória como narrativa e ipseidade, os abusos da memória e da comemoração, a escrita da história como mediação com o passado, os três estádios da operação historiográfica definidos por Certeau ${ }^{48}$ e retomados por Ricœur, e a história como representância ou, como gosta de lhe chamar Catroga, re-presentificação de um referente ausente. Transcrevemos um passo sintomático da forma como o historiador conimbricense perfilha assumidamente uma meditação ricœuriana, por sua vez apoiada em Michel de Certeau - também ele aqui muito citado -, a da poética da ausência, para suavemente introduzir um tema da sua eleição como historiador das ideias: o papel dos cemitérios e do culto dos mortos nas sociedades ocidentais. ${ }^{49}$

\footnotetext{
47 Ver nota 45 supra.

48 Michel de Certeau, L'écriture de l'histoire (Paris: Gallimard, 1975).

49 Fernando Catroga, o céu da memória. Cemitério romântico e culto cívico dos mortos (Coimbra: Minerva, 1999).
} 
... são conhecidas e pertinentes as posições que Ricœur tomou na contenda: para ele, a memória e a história (incluindo a historiografia) mantêm uma relação que, na perspetiva da inevitável presença de horizontes de pré-compreensão no questionamento historiográfico, consente pôr-se "la mémoire comme matrice de l'histoire" (Paul Ricœur, 2000).

Propendemos para concordar com os que sustentam esta tese. E se outras razões não houvesse, bastaria ir ao encontro da raiz de onde nasce a necessidade de recordar para a perfilharmos, a saber: a experiência humana de domesticar os mortos através do culto tanatológico. E, por mais estranho que à primeira vista possa parecer às leituras pouco sensíveis ao simbólico, a escrita da história também é, à sua maneira, "um gesto de sepultura". Com efeito, as narrações do passado são equiparáveis à linguagem dos cemitérios nas povoações, porque procuram "re-presentar [ou, dizemos nós, re-presentificar] mortos através de um itinerário narrativo" (Michel de Certeau, 1975). Portanto, pode afirmar-se que a historiografia também exorciza a morte, introduzindo-a no discurso para criar, como no jogo simulador e dissimulador do culto cemiterial dos mortos, a ilusão da sua não existência. 50

Prossegue desenvolvendo a analogia estabelecida por Michel de Certeau entre os cemitérios e as narrações do passado, partindo da etimologia de signo, que remete para túmulo:

Todo o signo funerário, explícita ou implicitamente, remete para o túmulo (signo deriva de sema, pedra tumular), isto é, para uma sobreposição de significantes ... E, neste jogo de negação da morte e da corruptibilidade do tempo, os signos "são assim dados

50 Fernando Catroga, Os passos do homem como restolbo do tempo. Memória e fim do fim da história. (Coimbra: Almedina, 2009), 34. 
em troca do nada segundo uma lei de compensação ilusória pela qual, quanto mais signos temos mais existe o ser e menos o nada" (Jean-Didier, 1997) ... Por isso, o túmulo e o cemitério devem ser lidos como totalidades significantes que articulam dois níveis bem diferenciados: um invisível e outro visível. E as camadas semióticas que compõem este último têm o papel de dissimular a degradação (o tempo) e, em simultâneo, de simular a não morte, transmitindo aos vindouros uma semântica capaz de individuar e de ajudar à re-presentação, ou melhor, à re-presentificação do ontologicamente ausente. É à luz destas características que é lícito falar, a propósito da linguagem cemiterial - tal como do discurso historiográfico -, de uma "poética da ausência"51

A segunda parte da obra dá grande destaque à hermenêutica histórica, mormente à tensão compreensão/explicação que Ricœur transformará em dialética. Embora Catroga faça uma apresentação histórica da temática que extravasa nalguns pontos a exposta por Ricœur, mais concisa a deste, em obras como Temps et Récit ou Du texte à l'action..., adivinha-se o texto ricouriano como matriz intelectual e operatória. O historiador mantém uma posição conivente com a do filósofo francês em toda a amplitude, distanciando-se por aí de parcialismos narrativistas. Ao mesmo tempo que reconhece como pernicioso o repúdio da história política e narrativa e se congratula pelo seu regresso, o próprio tem o cuidado de, no rasto de Ricœur, chamar a atenção para as insuficiências do narrativismo ou

51 Idem, op. cit., 39; cf. Fernando Catroga, Memória, História e Historiografia (Coimbra: Quarteto, 2001), pp. 40-44 e Idem, O Céu da memória. Cemitério romântico e culto cívico dos mortos (Coimbra: Almedina, 2006). A expressão "poética da ausência" é atribuída por Catroga a Ana Anais Gómez, "La sepultura, monumento que constituye la memoria de la vida", in AA. VV., Una Arquitectura para la muerte. I Encontro internacional sobre los cementerios contemporáneos (Sevilha: Junta de Andaluzia, 1995). A citação de Jean-Didier Urbain reporta-se a "Morte", Enciclopédia Einaudi, vol. 36, (Lisboa: Imprensa Nacional-Casa da Moeda, 1997). 
para visões parcelares do campo histórico. Declara o mesmo que "explicar por causas e/ou compreender intenções são atitudes que decorrem do jaez das perguntas feitas às informações retiradas da massa documental que o processo foi selecionando".52 E corrobora a sua afirmação citando Ricœur, de quem retirara o que acabava de afirmar:

Como afirmou Paul Ricœur (1955), "la compréhension n'est donc pas l'opposé de l'explication, elle en est au plus le complément et le contrepartie”. E, sem a obsessão do causalismo nomotético ou do dualismo à Dilthey, quem decide acerca do grau das suas correlações é a problemática. 53

Neste contexto, recorda ainda as várias etapas deste dualismo cognitivo a começar na reação da corrente hermenêutica (de Vico a Humboldt, Droysen, Windelband, Rickert, Simmel, Dilthey, Max Weber) ao cientismo positivista; o apagamento da narrativa e a luta do estruturalismo histórico francês contra a história metódica ou evenemencial, para logo a seguir focar também os retornos da narrativa, protagonizados pelo linguistic turn em reação aos defensores do modelo nomológico e à história económico-social, salientando como marco o artigo de Lawrence Stone. Relembra ainda a autocrítica dos Annales em finais da década de oitenta, que permitiu a recuperação da história política e narrativa, mas também a abertura a outras modalidades e objetos historiográficos, donde se destaca a micro-história e a sua aproximação ao acontecimento, à personagem, à mudança de escala e daí à narrativa.

52 Fernando Catroga, Os passos do homem como restolbo do tempo. Memória e fim do fim da história. (Coimbra: Almedina, 2009), 118.

53 Ibid. 
Sanada a tensão explicação/compreensão por via da dialética ricouriana, Catroga defende um caminho plural para a historiografia contemporânea, nisso se afastando claramente da perspetiva de Fátima Bonifácio. Na senda do filósofo francês, o autor admite a diversidade de métodos explicativos consoante a diversidade dos problemas e dos objetos por estes selecionados, "sem que isso signifique, contudo, a apologia de qualquer ecletismo, ou a busca de sínteses artificiais". ${ }^{54}$ Por conseguinte, em linha com Ricœur, ele vê com bons olhos a utilização de métodos quantitativos ou de leis de outras ciências, se estas ajudarem à explicabilidade de determinada interpretação histórica. Por outro lado, a pluralidade e renovação da historiografia atual mostra que outras interpretações históricas só ficarão comprovadas com o recurso a análises qualitativas, havendo outras que possam apelar mesmo a combinatórias metodológicas. Os debates epistemológicos contemporâneos são avessos a uma conceção unitária de ciência, anulando o conflito tradicional entre ciências da natureza e ciências do espírito. "A hora será de intercâmbio e de colaboração". 55

Outra problemática que merece a atenção de Catroga é a relação entre sujeito e objeto ou entre o historiador e passado. Neste âmbito, tornam-se assaz operativos dois conceitos fundamentais da epistemologia histórica ricœuriana: o conceito de operação historiográfica, axial para Ricœur-Certeau, e o de representância; o primeiro para credibilizar o trabalho do historiador, evitando derivas ficcionistas, revisionistas ou relativistas; o segundo para classificar o estatuto da mediação entre a narrativa e a realidade referenciada, evitando imediatismos positivistas do género adaequatio rei et intellectus.

${ }^{54}$ Idem, op. cit., 120.

55 Ibid. 
Foi precisamente para cortar com as ilusões vindas, quer da crença no mimetismo imediato da representação, quer, no polo oposto, da redução desta à pura ficcionalidade, que Paul Ricœur preferiu falar, já em Temps et récit e, depois, em La Mémoire, l'bistoire et l'oubli, em representância. 56

Por último relembra o autor o papel decisivo de Ricœur, Roland Barthes e Hayden White para a consciencialização epistemológica do estatuto narrativo da história, dizendo que depois dos seus escritos já nenhum historiador pode escamotear a forma narrativa do conteúdo histórico, ou julgar que a sua escrita é extrínseca e separável da verdade descritiva. O pensamento sobre o passado traduz-se em linguagem, em história a contar. Mas, tal como observou Ricœur em crítica a Hayden White, esta consciência exige prudência, para não se cair no extremo do narrativismo, e não se ser levado a esquecer que os textos que o historiador constrói não se esgotam na sua coerência interna ou num arquetípico-estrutural. Logo, considera Catroga "improfícua a adesão acrítica a algumas teses narrativistas". 57 Estamos nos antípodas do que preconizava Fátima Bonifácio.

\section{Conclusão}

A releitura e confronto destes dois historiadores e epistemólogos permite-nos tirar algumas conclusões breves relativamente à apropriação que fazem das teses de Ricour. Ambos leem o autor francês, são influenciados por ele e veiculam a sua hermenêutica histórica nos seus escritos. Não obstante, diferenças assinaláveis os separam. Fátima Bonifácio socorre-se da filosofia ricœuriana

\footnotetext{
56 Idem, op. cit., 127.

57 Idem, op. cit., 128.
} 
para justificar e sustentar uma opção historiográfica e ideológica específica. Com esse intuito, faz uma apropriação apenas parcial e conveniente, ignorando uma parte substancial do todo que lhe era incómoda. Sem embargo, a opção pela história política narrativa não põe em causa o rigor e a excelência das suas investigações e produções historiográficas, como bem o comprovam os estudos de história política do século XIX subsequentes ao ensaio epistemológico por nós analisado e muitos outros que vem publicando. Em linha com o que temos vindo a dizer, hoje a história é plural e admite no seu interior vários modelos explicativos, com a única exigência metodológica de haver acerto entre o objeto, a problemática e o modelo explicativo. Fátima Bonifácio, em função de uma história política que determinou como objeto de estudo, aplica com eficácia e legitimidade o modelo explicativo narrativo, atinente à explicação por razões. Esta opção, sendo coerente, não pode ser criticável. É, ademais, salutar que num país onde a maioria dos historiadores tendeu para as propostas dos Annales, haja quem se ocupe de história política, sem a qual corremos o risco de passar ao lado de grandes acontecimentos transformadores das sociedades. Não sendo um ramo da historiografia que atraia muitos adeptos no nosso país, há ainda uns quantos assinaláveis e dignos de menção: casos de Vasco Pulido Valente, ${ }^{58}$ Rui Ramos, ${ }^{59}$ ou José Pacheco Pereira, ${ }^{60}$ autores de inestimáveis trabalhos de história política.

Catroga, por seu turno, faz uma leitura mais abrangente e ideologicamente descomprometida das teses de Ricœur, as quais se refletem substancialmente nos seus escritos e preleções de Teoria

58 Vasco Pulido Valente, Portugal. Ensaios de História e de Política (Lisboa: Alêtheia, 2009).

59 Rui Ramos (coord.), História de Portugal (Lisboa: Esfera dos livros, 2009).

60 Vide os quatros volumes já publicados por José Pacheco Pereira sobre a icónica figura do comunismo português: Álvaro Cunhal - Uma biografia política (Lisboa: Círculo de Leitores/Temas e Debates, - vol. I 1999; vol. II 2001; vol. III 2005; vol. IV 2016). 
e Filosofia da História. Tem da hermenêutica histórica ricœuriana uma conceção rigorosa e bem assimilada, donde ressumbra não só a admiração pela figura do filósofo, mas também uma extraordinária capacidade para o integrar e diluir nas suas próprias reflexões. Também nas suas alocuções o nome do filósofo francês se ouve amiúde, alcançando, por vezes, o professor e historiador problemáticas ricœurianas ainda não refletidas nos seus livros, caso da teoria do Mesmo, do Outro e do Análogo, desenvolvida por Ricœur em Temps et récit, como caminho intelectual para chegar à criação do conceito de representância. Estamos certos, por isso, de que novas vertentes do pensamento de Ricœur poderão aflorar em futuras publicações de Fernando Catroga. 



\title{
LA VÍCTIMA COMO SUJETO CAPAZ. A PROPÓSITO DELCONFLICTOCOLOMBIANO
}

\author{
THE VICTIM AS A CAPABLE SUBJECT. \\ NOTES ON THE COLOMBIAN CONFLICT
}

Manuel Prada Londoño Universidad de San Buenaventura ${ }^{1}$

\begin{abstract}
Resumen: Este trabajo explora la tesis según la cual las víctimas deben ser asumidas como sujetos de derecho, esto es, como lo que Ricœur denomina "sujetos dignos de estima y respeto". Esta asunción requiere el ejercicio pleno de las capacidades, lo cual sólo es posible en escenarios de reconocimiento mutuo, en los que, a su vez, está comprometida la atestación del sujeto responsable del otro en la figura de la víctima.

El texto está organizado en cinco apartados precedidos de una breve introducción: en los dos primeros se aborda de modo general la noción de "víctima"; el tercero aborda la idea de "víctima como sujeto capaz"; el cuarto trata del reconocimiento mutuo como escenario de realización de las capacidades de
\end{abstract}

${ }^{1}$ Manuel Prada Londoño, Doctorado en Humanidades. Humanismo y Personas DHUPE, Universidad de San Buenaventura, Bogotá, Colombia. E-mail: mpradalon@ gmail.com 
los sujetos, especialmente de las víctimas; y el último apartado hace las veces de conclusión de todo el recorrido.

Palabras clave: atestación; hombre capaz; reconocimiento; sujeto de derecho; víctima.

\begin{abstract}
This paper explores the thesis according to which victims should be taken as subjects of rights, that is, as what Ricœur calls "subjects worthy of esteem and respect". This assumption requires the full exercise of capabilities, which is only possible in mutual recognition scenarios, in which, at the same time, what is at stake is the attestation of the subject who is responsible for the other that appears under the figure of the victim.

This paper is organized in five sections preceded by a brief introduction. A general notion of "victim" working as a frame of the reflection is presented in the first and second sections; the third section is devoted to the idea of a "victim as a capable subject"; the fourth section is dedicated to mutual recognition as a requirement for the realization of victims as subjects of rights; the last section presents some general ideas related to attestation of the subject.
\end{abstract}

Keywords: attestation; capable man; recognition; subject of rights; victim.

\title{
Introducción
}

Este ensayo se realizó como parte del proyecto de investigación "Ciudadanía e identidad ante las víctimas. Configuración de ciudadanía en Colombia" llevado a cabo en la Universidad de San 
Buenaventura (Bogotá, Colombia) entre 2010 y 2011.2 El proyecto surgió sobre todo por la convicción de que la Filosofía tiene mucho por decir en contextos como el colombiano y, de forma más particular, respecto a las discusiones que se estaban llevando a cabo en torno a la llamada "Ley de víctimas" aprobada en 2011. Vimos que, además de las problemáticas históricas, jurídicas o económicas que la ley suscitó en su momento, era necesario hacer unas consideraciones de carácter antropológico y ético que permitieran poner en el centro del debate a la víctima misma: ¿quién es la víctima? ¿De qué es víctima? ¿Es posible salir de la condición de víctima? ¿Cómo?3

El grupo de investigación comenzó a trabajar en febrero de 2010. En el diseño de la investigación estaba previsto que se examinara la noción de víctima y las posibilidades de restitución de su condición de ciudadanos a la luz de tres grandes referentes: 1) un referente histórico, que se concentraría en revisar las múltiples cronologías del conflicto colombiano y en establecer puntos comunes y divergentes que permitieran entender algunos antecedentes de la Ley de víctimas; 2) un primer referente filosófico especialmente inspirado en Walter Benjamin y la lectura que de él hace Reyes Mate en el que la noción de "víctima" ocupa un lugar protagónico; 3) un segundo referente filosófico centrado en filosofías latinoamericanas de carácter post-colonial. Al entrar a formar parte de la Facultad de Filosofía en agosto de ese mismo año, fui invitado a participar en este grupo; y dado que el "espíritu" del trabajo fue de total apertura a mis intereses, consideré que Paul Ricœur sería una buena

\footnotetext{
${ }^{2}$ Este proyecto estuvo bajo la dirección de la profesora Tulia Almanza y contó con la participación de los colegas Giovanni Púa y William Rojas.

3 Seguramente este capítulo sufriría modificaciones si tuviera en cuenta las discusiones suscitadas en y por el reciente proceso de negociación entre el gobierno y las FARC. Sin embargo, en lo fundamental, creemos que la tesis se mantiene, lo que significa a su vez que no puede haber paz si no hay reconocimiento de las víctimas como sujetos capaces, dignos de estima y respeto.
} 
guía para profundizar en el problema filosófico de las víctimas en el contexto colombiano.

No obstante, como siempre se intentó que hubiera diálogo entre los tres referentes, la primera parte del presente texto esboza una relación con el segundo referente filosófico que hemos mencionado. Empero, es necesario advertir que no se presentan sistemáticamente las líneas generales que vinculan o en las que se distancian Ricœur y Benjamin/Reyes Mate. El lector encontrará más bien un tono común que permite el diálogo, tono que está inspirado por la propuesta ricouriana.

Las otras secciones del capítulo se centran en la perspectiva de Ricœur y desarrollan la tesis según la cual las víctimas deben ser asumidas como sujetos de derecho, esto es, como lo que el francés denomina "sujetos dignos de estima y respeto". Esta asunción requiere el ejercicio pleno de las capacidades, que solo es posible en escenarios de reconocimiento mutuo, en los que, a su vez, está comprometida la atestación del sujeto responsable del otro en la figura de la víctima.

\section{1 - La pregunta por las víctimas. Una lectura con Benjamin y Reyes Mate}

Advierte Walter en la VI de sus Tesis sobre la bistoria: "Articular históricamente el pasado no significa conocerlo 'tal como verdaderamente fue'. Significa apoderarse de un recuerdo tal como éste relumbra en un instante de peligro". ${ }^{4}$ No poder conocer el pasado, en los términos enunciados por Benjamin, señala la imposibilidad que nos marca el pasado precisamente porque ya no es más; lo

${ }^{4}$ Walter Benjamin, Tesis sobre la historia y otros fragmentos, trad. Bolívar Echeverría (Bogotá: Desde abajo, 2010), 22. 
sucedido es irrepetible, no puede recuperarse sino por el recurso a la memoria o a diversos tipos de archivo, siempre marcados por la distancia entre lo acontecido y nosotros, así como por la amenaza del olvido.

A su vez, las formas de recuerdo individual y colectivo en las que se configuran nuestras maneras de entender la historia personal y social, las identidades individuales y sociales, la problemática diversidad cultural, la paz o la violencia, dependen no sólo de la estructura misma del acto de recordar - que, al requerir selectividad, está aguijoneada por el olvido -, sino de diversos poderes políticos y económicos que pugnan por imponer, al mismo tiempo que por ocultar, ciertos recuerdos, hechos o agentes.

Esta pugna nos lleva a reflexionar también sobre la prevalencia de un relato trágico, hegemónico, "defensor del statu quo, globalizador de las dependencias y sustentador de las ciudadanías de excepción" , esto es, aquellas que viven en un contexto marcado por "aumento de la desigualdad social, des-legitimidad del sistema político, disminución de la participación ciudadana y bancarrota de imaginarios nacionales orientados hacia la construcción de un esperanzado porvenir". ${ }^{6}$

Así las cosas, queda claro que el instante del peligro en el que se halla el pasado no se advierte por un prurito objetivista o una nostalgia epistemológica de acceder directamente al pasado. Esta mirada tampoco es la de la filosofía de la historia que no logra ver las evidencias esperadas de un progreso moral de la humanidad, ni la del pesimista que plantea su grito con el color del desconsuelo que le otorgan los signos visibles de una decadencia en diversos órdenes y extendida hoy en día a la esfera global. Es una mirada

\footnotetext{
5 Alexander Ruiz, Nación, moral y narración. Imaginarios sociales en la enseñanza y el aprendizaje de la historia (Buenos Aires: Miño y Dávila, 2011), 39.

${ }^{6}$ Ibid., 35.
} 
ética que descubre cómo el querer vivir juntos de hombres y mujeres, y la multiplicidad de formas de relatar el despliegue de ese deseo, parece entregarse con frecuencia a la barbarie; pero también es una mirada que, a pesar de reconocer señales de esperanza en la historia, tiene razones de sobra para coincidir con el lamento de Benjamin: "Quien hasta el día actual se haya llevado la victoria, marcha en el cortejo triunfal en el que los dominadores de hoy pasan sobre los que también hoy yacen en tierra. Como suele ser costumbre, en el cortejo triunfal llevan consigo el botín. Se le designa como bienes de cultura". 7

Si seguimos leyendo la tesis VI de Benjamin, encontramos otro matiz de la advertencia respecto al "instante de peligro": "tampoco los muertos estarán seguros ante el enemigo cuando éste venza. Y este enemigo no ha cesado de vencer". ${ }^{8}$ El enemigo es el olvido instaurado por las voces de los "vencedores" que promueven el peligro de la desaparición de los "vencidos" por vía de una doble violencia: desaparición física, exterminio, aniquilación o expropiación - aceptadas como naturales y necesarias - y desaparición simbólica auspiciada por una hermenéutica histórica que se empecina en ubicar a los "otros", buenos, pero prescindibles, en el "polo del bárbaro y del vencido", 9 y frente a los que apenas cabe sentir una "tibia empatía". Esa misma violencia hermenéutica que inclina la balanza de la memoria y de la historia a la aniquilación es la que posibilita que a los muertos del pasado se sumen impunemente los muertos del presente, en un mismo relato de progreso que deja por fuera toda posibilidad de lecturas alternativas de la historia.

Por otra parte, para Reyes Mate, la experiencia histórica de nuestro siglo nos pone frente al escándalo de estar "haciendo las cosas

\footnotetext{
${ }^{7}$ Benjamin, Tesis sobre la historia, tesis VIII, 24.

8 Ibíd., 22.

9 Ruiz, Nación, moral y narración, 163.
} 
de tal manera que si las víctimas levantaran la cabeza verían con asombro que nada ha cambiado sobre ellos en la conciencia de las nuevas generaciones". ${ }^{10}$ Y la razón de este desvío permanente, a su juicio, es que hemos olvidado que "[no] se puede ser digno de la dicha a costa de los no dichosos". ${ }^{11}$

Este olvido contrasta con el horror que experimenta el ángel de la historia de la muy conocida Tesis IX, en la que Benjamin interpreta un cuadro de Klee titulado Angelus novus:

Se ve en él un ángel, al parecer en el momento de alejarse de algo sobre lo cual clava la mirada. Tiene los ojos desorbitados, la boca abierta y las alas tendidas. El ángel de la historia debe tener ese aspecto. Su rostro está vuelto hacia el pasado. En lo que para nosotros aparece como una cadena de acontecimientos, él ve una catástrofe única, que arroja a sus pies ruina sobre ruina, amontonándolas sin cesar. El ángel quisiera detenerse, despertar a los muertos y recomponer lo destruido. Pero un huracán sopla desde el paraíso y se arremolina en sus alas, y es tan fuerte que el ángel ya no puede plegarlas. Este huracán lo arrastra irresistiblemente hacia el futuro, al cual vuelve las espaldas, mientras el cúmulo de ruinas crece ante él hasta el cielo. Este huracán es lo que nosotros llamamos progreso. ${ }^{12}$

Reyes Mate resalta de esta tesis el contraste entre dos actitudes: la del ángel, que "ve una catástrofe única", y la nuestra que sólo puede ver "una lógica de acontecimientos". ${ }^{13}$ ¿Acaso es natural que esto sea así? De ninguna manera, responde Reyes Mate. Vemos

\footnotetext{
10 Manuel Reyes Mate, La razón de los vencidos (Barcelona: Ánthropos, 2008), 169.

11 Ibíd., 192.

12 Benjamin, Tesis sobre la historia, 24-25.

13 Reyes Mate, La razón de los vencidos, 205.
} 
dicha lógica porque nos hemos habituado a los acontecimientos, porque nos parecen "normales" o, al menos, porque ya no nos sorprenden: en la escuela, por ejemplo, se nos ha sugerido, cuando no se nos ha explicado o instado a creer en ello, que el exterminio de comunidades enteras (indios, negros, campesinos), la esclavitud, las formas indignas de trabajo asalariado, la conformación de una sociedad profundamente jerárquica y desigual que se origina desde las prácticas coloniales, y se extiende a las diversas versiones de república que hemos tenido, obedecen al cumplimiento de una especie de destino; ${ }^{14}$ en los medios de comunicación nos bombardean con las promesas del progreso - proferidas por banqueros, organismos multilaterales, partidos políticos, economistas - que, dicen, se realizará si se sacrifican poblaciones o países prescindibles; y en la vida cotidiana, parece imponerse la idea - con sus prácticas consecuentes - según la cual sólo el más fuerte es el que sobrevive en un mundo signado por el "sálvese quien pueda".

La filosofía de inspiración benjaminiana, en cambio, nos insta a un combate contra el olvido, que exige tomar en nuestras manos "todos esos sueños de felicidad, otrora pastoreados por la religión y que ahora tienen que pasar a la filosofía", y hacernos "cargo de esas ansias insatisfechas o de esos derechos pendientes [de los "vencidos"]" a fin de "desenmascarar y superar las barreras del

\footnotetext{
14 Para una crítica a la enseñanza de la historia en la escuela colombiana que se articula con la idea de Reyes Mate de "normalizar" ciertos acontecimientos que borran a unos seres humanos y resaltan a otros, ver de Sandra Rodríguez Ávila: "Formación de maestros para el presente: memoria y enseñanza de la historia reciente", Revista Colombiana de Educación 64 (2011): 165-188; "Enseñanza y aprendizaje de la historia en Colombia 1990-2011", en La investigación en la enseñanza de la historia en América Latina, coord. Sebastián Plá y Joan Pagés (México: Bonilla Artigas Editores, 2014), 109-154. Aunque referido a la enseñanza de la historia en Argentina, el trabajo de Alexander Ruiz que hemos citado más arriba da cuenta de una crítica similar.
} 
presente, que es el de los vencedores" ${ }^{15}$ En últimas, nos convoca a asumir que

nosotros podemos romper nuestras cadenas recordando que la actualización de las esperanzas pasadas e insatisfechas puede, en primer lugar, alumbrar nuestra conciencia respecto a la existencia de nuestras propias cadenas y, luego, transmitirnos su esperanza en virtud de la cual poder luchar contra las cadenas. La esperanza no nace de seres satisfechos sino insatisfechos". ${ }^{16}$

Esa rehabilitación de la esperanza que se funda en la insatisfacción respecto a un estado de cosas se enfrenta al menos con dos dificultades: la primera, insalvable, la de la validez de los derechos pendientes y de las ilusiones insatisfechas que no puede ser reclamada por las víctimas. En sentido estricto, a juicio de Benjamin y Reyes Mate, las víctimas ya no están entre nosotros, no pueden reclamar algo para sí pues han muerto. Así se entiende la idea según la cual "sólo recuerdan los sobrevivientes". ${ }^{17}$

El recuerdo de quienes sobreviven o de quienes no son víctimas directas de la guerra o de cualquier tipo de violencia es la compasión. Ésta "se produce en relación a (sic) un sufrimiento que conocemos", y "no es inicialmente un acto racional, sino sentimiento y voluntad, [que] tiene que doblarse en reflexión para incorporar intelectualmente la plusvalía de significado que conllevan las víctimas anónimas". ${ }^{18}$ La dificultad entonces se convierte en el reto de hallar formas de realización de esta plusvalía, superando tanto la

\footnotetext{
15 Reyes Mate, La razón de los vencidos, 206.

16 Ibid., 207.

17 Ibid., 212.

18 Ibíd., 213.
} 
indiferencia, como la lástima inactiva rayana en la connivencia o el deseo de venganza.

La segunda dificultad remite a que la esperanza lucha contra "la aceptación de un presente - y de sus estructuras - construido sobre los derechos de los vencedores". ${ }^{19}$ Tal aceptación nos impide vivir la solidaridad con el pasado, que se transfigura en solidaridad con el necesitado, informada racionalmente "al considerar... que el otro no es un pobre hombre, sino un hombre al que se le ha privado de la dignidad de sujeto". ${ }^{20}$ De hecho, aceptar estos basamentos nefastos del presente es cerrarse a la posibilidad de asumir que cuando todo otro es negado en su dignidad "yo mismo (es decir, el otro polo de la relación compasiva) me descubro privado de la dignidad y dependiendo del otro". ${ }^{21}$ Así, pues,

"si llamamos solidaridad al movimiento compasivo del yo al otro, hay que nombrar el movimiento contrario, el que viene del otro al yo, condición de posibilidad de la propia constitución en sujeto moral. ... Sólo hay sujetos morales cuando la relación es simétrica, pero hasta llegar ahí los dos sujetos necesitan el reconocimiento del otro, aunque no de la misma manera. Aquí debe (en el sentido de deuda y de obligación) más quien más tiene". ${ }^{22}$

\footnotetext{
19 Ibid., 216.

20 Ibid., 19.

21 Ibíd., 153.

22 Ibíd., 155. Sea este el momento para anotar que podría explorarse un matiz ricouriano que establecería cierta distancia respecto a la lectura de Reyes Mate. Ricœur señala que es constitutivo de nuestras relaciones con los otros (sea en el modo del cara a cara, sea con el "tercero") la tensión entre disimetría - entendida como inconmensurabilidad entre uno mismo y los otros - y búsqueda de reciprocidad que teje el querer vivir juntos. Así pues, el autor de Parcours de la reconnaissance no se cansó de insistir en que la búsqueda de la reciprocidad no elimina la disimetría constitutiva entre los seres humanos, incluso si tal reciprocidad acaece como mutualidad, esa forma particular de reconocimiento mutuo que no se fija en $l o$ que intercambian las personas, sino en las personas mismas. Ver: Parcours de la reconnaissance. Trois études (Paris: Stock, 2004), 319-354. A la luz de lo anterior, parece necesario al menos sugerir que el reto de la formación de
} 


\section{2 - La noción de víctima. Esbozo de algunas dificultades}

La pregunta por las víctimas, ${ }^{23}$ tal como advierte Ricour, es la pregunta por los olvidados de la historia, los que han carecido definitivamente de voz y son ese "otro que es distinto de nosotros". ${ }^{24}$ Es el revés del interrogante por cómo se ha construido nuestra historia colectiva lo que nos obliga a asumir el reto moral de "extraer de los recuerdos traumatizantes su valor ejemplar" con lo cual la memoria se convierte en proyecto de futuro y de justicia. ${ }^{25}$

Asimismo, no es entusiasmo vacío o cólera - contra los que advierte Ricœur - lo que nos mueve a recordar que la producción de

sujetos morales es mayor en tanto la disimetría, que según Ricœur es ontológicamente insuperable, atraviesa todas las relaciones intersubjetivas y se acrecienta en situaciones en las que la solidaridad no se da entre iguales, pues hay unos que están limitados en sus poderes. Es justamente esa limitación la que mueve al sí mismo a una solidaridad que se hace responsable. Ante el sufrimiento viene la respuesta de la iniciativa que "parece incumbir exclusivamente al sí que da su simpatía, su compasión". Aquí estamos ante una disimetría fuerte, pero también ante otra forma de simetría: "En la simpatía verdadera, el sí, cuyo poder de obrar es, en principio, más fuerte que el de su otro, se encuentra afectado de nuevo por todo lo que el otro sufriente le ofrece a cambio. Pues del otro que sufre procede un dar que no bebe precisamente en su poder de obrar y de existir, sino en su debilidad misma". Esta es la "prueba suprema de la solicitud", acaecida en la sutileza de lo simple que combate a su manera el dolor exacerbado. Más aún: "Un sí llamado a la vulnerabilidad de la condición mortal puede recibir de la debilidad del amigo más de lo que él le da bebiendo en sus propias reservas de fuerza" (todas las citas de este párrafo corresponde a: Paul Ricœur, Soi-même comme un autre (Paris: Seuil, 1990), 223. Aunque hemos consultado las traducciones al castellano disponibles, citamos directamente de las versiones originales). En suma, la formación del sujeto moral se juega en una especie de concordancia discordante entre disimetría constitutiva y simetría pretendida, entre la disimetría de la solidaridad y el aprendizaje de la finitud en el dolor del otro, entre iniciativa de ayuda y reconocimiento del carácter necesitado del sí mismo. Ver: Manuel Prada, Entre disimetría y reciprocidad. El reconocimiento mutuo según Paul Ricœur (Bogotá: Aula de Humanidades - Editorial Bonaventuriana, 2017).

23 Atrás hemos usado "vencidos" o "víctimas" indistintamente, siguiendo a Reyes Mate. Sin embargo, preferimos decir "víctimas" al tener presente la indicación de Ricœur según la cual "los vencidos son, en parte, los candidatos a la dominación que han fracasado" (Paul Ricœur, Temps et récit. 3. Le temps raconté (Paris: Seuil, 1985), 340.

${ }^{24}$ Paul Ricœur, La mémoire, l'histoire, l'oubli (Paris: Seuil, 2000), 108.

25 Ibíd., 107. 
un rosario interminable de víctimas olvidadas es constitutiva de la historia de nuestro pueblo colombiano y latinoamericano. La pregunta por las víctimas es motivada por el anhelo de mantener, avivar o recuperar nuestra constitución como sujetos morales, según nos lo recuerda Reyes Mate: "La constitución del hombre como sujeto moral se produce en una relación intersubjetiva, en una aproximación al otro. ... La universalidad es el grito del necesitado. ... No hay sujeto moral más que como respuesta a esa demanda". ${ }^{26}$

Antes de presentar la reflexión sobre las víctimas a la luz de la fenomenología del hombre capaz, es necesario situar algunas dificultades que se nos presentaron en la comprensión de la noción misma de víctima.

Ricœur define "víctima" como aquel que padece una disminución o aniquilación de su poder-hacer causada por el poder-hacer de otro. El espectro de situaciones que cabe aquí es muy amplio: tortura, desaparición forzada, desplazamiento o asesinato, pero también sutiles formas de humillación, violencias del lenguaje o astucias propias de la "intimidad del cuerpo-a-cuerpo". ${ }^{27}$ De esta manera, la noción de víctima puede operar en el análisis de las relaciones intersubjetivas con el prójimo, con el allegado o con cualquier otro, un tercero.

En la investigación en la que se enmarca este trabajo, nuestra atención se centró en el conflicto armado en Colombia, lo que nos sitúa frente a víctimas de actores definidos (Estado, paramilitares, guerrilla) y en un escenario limitado, el rural. ${ }^{28}$ No obstante, el fenómeno "violencia" es de tal envergadura, que se puede identificar en múltiples escenarios de la geografía nacional y de la vida

26 Reyes Mate, La razón de los vencidos, 146-147.

27 Ricœur, Soi-même comme un autre, 257.

28 Tulia Almanza; Giovanni Púa; William Rojas y Manuel Prada. Ciudadanía e identidad frente a las víctimas. La configuración de la ciudadanía en Colombia (Informe final de investigación, Universidad de San Buenaventura - Facultad de Filosofía, 2012). En el presente trabajo no nos ocupamos de actores y escenarios específicos que caracterizan el conflicto armado en Colombia. 
social, cultural y política colombiana en realidades tales como la imposibilidad de realizar proyectos vitales a causa de la ausencia de garantías en el cumplimiento y la protección de los derechos, el empobrecimiento sistemático, la estigmatización del "diferente", la desesperanza aprendida o la indiferencia, que sirven de caldo de cultivo al mismo conflicto armado. ${ }^{29}$

Otra de las dificultades estuvo atravesada por la pregunta: "¿Quién es la víctima?". No hay obstáculo en identificar como víctima al desplazado, al asesinado, al desaparecido o a sus familiares. Pero, ¿desde cuándo?, ¿las víctimas de qué período histórico? La aprobación de la Ley de víctimas (ley 1448 de 2011) fue el telón de fondo de estas preguntas, al determinar en su articulado que, para el conflicto específico al que respondía, son considerados víctimas

... aquellas personas que individual o colectivamente hayan sufrido un daño por hechos ocurridos a partir del $1^{\circ}$ de enero de 1985, como consecuencia de infracciones al Derecho Internacional Humanitario o de violaciones graves y manifiestas a las normas internacionales de Derechos Humanos, ocurridas con ocasión del conflicto armado interno. También son víctimas el cónyuge, compañero o compañera permanente, parejas del mismo sexo y familiar en primer grado de consanguinidad, primero civil de la víctima directa, cuando a esta se le hubiere dado muerte o estuviere desaparecida. A falta de estas, lo serán los que se encuentren en el segundo grado de consanguinidad ascendente. De la misma forma, se consideran víctimas las personas que hayan

${ }^{29}$ Una lectura muy amplia y con puntos de vista no solo diversos sino contradictorios sobre los orígenes y el desarrollo del conflicto armado en Colombia la hallamos en: Comisión Histórica del Conflicto Armado y sus Víctimas, Contribución al entendimiento del conflicto armado en Colombia (Bogotá: Comisión Histórica del Conflicto Armado y sus Víctimas, 2015, documento de trabajo, http://www. altocomisionadoparalapaz.gov.co/oacp/Pages/informes-especiales/resumen-informe-comision-historica-conflicto-victimas/el-conflicto-y-sus-victimas.aspx). 
sufrido un daño al intervenir para asistir a la víctima en peligro o para prevenir la victimización. 30

Aclara también la Ley que "las personas que hayan sido víctimas por hechos ocurridos antes del $1^{\circ}$ de enero de 1985 tienen derecho a la verdad, medidas de reparación simbólica y a las garantías de no repetición previstas en la presente ley, como parte del conglomerado social y sin necesidad de que sean individualizadas". ${ }^{31}$

Las reflexiones que se presentan en este trabajo proponen ir más allá de la letra de la Ley, amparadas como están en la convicción según la cual es necesario reconocer que la historia nacional está tejida sobre distintas violencias evidentes u ocultas, sistemáticas unas, esporádicas otras, que han dejado a su paso la negación del poder hacer de quienes las han padecido. No nos adentramos aquí en el análisis de las implicaciones jurídicas, sociales y económicas que tiene el artículo citado, ni en la Ley en su conjunto, ni negamos que su proclamación ha sido motivo de esperanza para quienes estamos convencidos de la necesidad de sostener jurídicamente la reparación de las víctimas. Sin embargo, atendiendo de nuevo a la relación entre solidaridad y formación moral del sujeto, siempre es necesario recordar que una ley, por más pertinente y completa que ella sea, no agota las posibilidades de acudir al llamado que hace el rostro del otro sufriente. ${ }^{32}$

30 Ley 1448 de 2011, Art. 3, http://www.alcaldiabogota.gov.co/sisjur/normas/ Norma1.jsp?i=43043. La Corte Constitucional, mediante Sentencia C-250 de 2012, declaró exequible este límite temporal.

31 Art. $3^{\circ}$, par. 4.

32 Nos enfrentamos a una tensión entre dos perspectivas (que este trabajo no logra salvar): por una parte, la que apunta la necesidad teórica, para el análisis al que nos abocamos, de acotar qué y quién es la víctima del conflicto armado, a lo que se suma una necesidad política y jurídica de establecer cargas, señalar responsabilidades, proyectar reparaciones. Sin ese "recorte" conceptual y sin sus consecuencias jurídicas, se corren al menos dos riesgos: que cualquiera pueda reclamar su condición de víctima, y la ley, junto con las luchas sociales y políticas, sean ineficaces o estériles. Por otra, la que advierte de la estrechez de miras, incapaz de sacar a la 
La tercera dificultad que nos hallamos se refiere al "peligro exorbitante que coloca al resto de la gente en posición de deudor de créditos" respecto a las víctimas. ${ }^{33} \mathrm{Si}$ cualquiera de nosotros puede eventualmente ejercer su poder sobre otro hasta llegar a disminuir o negar su poder-hacer, ¿todos, entonces, somos igualmente responsables? Si todos somos responsables, es probable que nadie lo sea, que la responsabilidad se diluya al punto de desaparecer. Sólo un discurso populista, demagógico o encubridor puede pretender que todos respondan ante las masacres, los desplazamientos o el empobrecimiento sistemático de miles de colombianos como si ejercieran los mismos cargos, u ostentaran idénticos poderes. Ciertamente, podría trazarse una cartografía cultural, política, económica y moral de imputación de responsabilidades que atañen a diversos actores de la sociedad civil, pero sin que ello impida nombrar, juzgar y sentenciar a miembros del gobierno, de las fuerzas militares, de los grupos alzados en armas, o a empresarios y multinacionales. En suma, la imputación de responsabilidades requiere poner en una balanza acciones, agentes y motivos para distinguir y juzgar con justicia.

Unida a esta dificultad, con Ricœur podemos alertar respecto a la imposición de un deber de memoria reclamado por quienes no han sufrido los vejámenes del conflicto armado, pero que sacan provecho de alguna cercanía con las víctimas sin que medie en ello un auténtico espíritu de solidaridad. ${ }^{34}$ La advertencia de Ricour no significa, en modo alguno, un desconocimiento del deber de

luz las víctimas de violencias estructurales que no necesariamente pasan por lo que ha definido la ley y que, sin embargo, existen y nos interpelan moralmente.

33 Ricœur, La memoire, l'histoire, l'oubli, 104.

${ }^{34}$ En este punto se requiere mucha cautela. Algunos sectores políticos colombianos han argüido que las ONGs, los colectivos de abogados, los movimientos sociales o los defensores de derechos humanos sólo pretenden beneficiarse económica o políticamente del supuesto botín que deja la defensa de las víctimas. Está claro que hay una intención de desacreditar este trabajo, y que no nos unimos a ella. No obstante, la advertencia de Ricœur es sensata y por ello la incluimos aquí. 
memoria, que "no se limita a guardar la huella material, escrituraria u otra, de los hechos pasados, sino que cultiva el sentimiento de estar obligados respecto a estos otros... que ya no están pero que estuvieron". En últimas, "entre estos otros con los que estamos endeudados, una prioridad moral corresponde a las víctimas. ... La víctima de la que se habla aquí es la víctima que no es nosotros, es el otro distinto de nosotros". 35

\section{3 - Las víctimas como sujetos capaces}

Una vez dibujado el horizonte desde el que se nos presenta la pregunta por las víctimas, e identificadas algunas dificultades a la hora de establecer una noción que nos permita afinar los análisis posteriores y el diálogo con otros actores de la sociedad civil, veamos ahora lo que significa que las víctimas tienen que ser asumidas como sujetos de derecho.

En primer lugar, hay que anotar que, para Ricœur, las consideraciones sobre la vida política - en las que nosotros inscribimos la reflexión sobre las víctimas y su aplicación al conflicto armado colombiano - están soportadas por una visión antropológica. En otras palabras, llegamos al asunto del "sujeto de derecho" por la meditación sobre el hombre capaz como "sujeto digno de estima y respeto". ${ }^{36} \mathrm{Al}$ mismo tiempo, como veremos más adelante, el poder humano no es realizable plenamente, desplegado en las capacidades de decir, hacer, narrar y ser sujeto de imputación, sin diversas mediaciones intersubjetivas e institucionales. Aunque el discurso de las capacidades se haga privilegiadamente en primera persona, es la mediación del otro - en su doble dimensión: el otro de la relación

35 Ricœur, La memoire, l'histoire, l'oubli, 108.

36 Paul Ricœur, Le juste (Paris: Esprit, 1995), 29. 
cara a cara y el "cualquier otro" o el "tercero" de las relaciones sociales más amplias - la que permite "el trayecto de la capacidad a la efectuación". ${ }^{37}$

Las capacidades son "estos poderes básicos [que] constituyen el primer cimiento de la humanidad, en el sentido de lo humano opuesto a lo inhumano". ${ }^{38}$ Esos poderes van aparejados con un no-poder constitutivo ${ }^{39}$, con la pasividad que hiere las pretensiones de autosuficiencia de los sujetos y que apuntan a "formas de fragilidad ciertamente inherentes a la condición humana”, pero que se agudizan en contextos que refuerzan e instauran esa heteronomía por la vía de desigualdades crecientes. ${ }^{40}$

El sufrimiento de las víctimas va más allá de ese no-poder constitutivo, de la pasividad propia del sí mismo. Lo que es necesario precisar en el caso de las víctimas es que la violencia que se ejerce sobre ellas es una agudización extrema de dicho no-poder. ${ }^{41}$ Las víctimas son testigos sufrientes de la negación de todo poder; su pasividad aquí no da cuenta de una ontología quebrada, como leemos en el estudio IX de Soi même comme un autre, sino que enrostra el horror de la negación de humanidad.

37 Ricœur, Soi-même comme un autre, 212.

38 Paul Ricœur, "Capacités personnelles et reconnaissance mutuelle", en Anthropologie philosophique. Écrits et conférences 3 (Paris: Seuil, 2013), 446.

39 Domenico Jervolino, "El cogito herido y la ontología del último Ricœur", en Fenomenología por decir. Homenaje a Paul Ricœur, ed. Patricio Mena (Santiago de Chile: Universidad Alberto Hurtado, 2006), 75.

40 Paul Ricœur, Le juste 2 (París: Esprit, 2001), 26.

${ }^{41}$ Esta agudización recibe el nombre de violencia, que es vista por Ricœur "como un término amplio para referir a cualquier práctica en la que las personas son 'instrumentalizadas' por un propósito teleológico extraño o fragmentador" (John Wall, "Moral Meaning. Beyond the Good and the Right", en Paul Ricour and Contemporary Moral Thought, comp. de William John y David Hall (Londres: Routledge, 2002), 53; citado en Silvia Gabriel, "Razón práctica y violencia en Paul Ricœur", Dianoia LVI, n. ${ }^{\circ} 66$ (Mayo 2011): 62). Pueden verse algunas precisiones respecto a los usos del concepto "violencia" en la obra de Ricœur, más específicamente a propósito de la política en: Graciela Ralón, "Violencia e historia", Investigaciones fenomenológicas. Número monográfico: Fenomenología y política, $\mathrm{n}^{\circ} 3$ (2011): 408-417. 
Decir "negación de humanidad" tiene que ver con el carácter concreto de hombres y mujeres con nombres propios, con historias de vida truncadas y esperanzas suspendidas, cuando no cercenadas, es decir, tiene que ver con la negación de la respuesta a la pregunta: ¿quién soy yo? Esa pregunta, cuya enunciación resulta las más de las veces imposible para las víctimas, reaparece de otra manera en nuestra meditación filosófica y en nuestras consideraciones como ciudadanos: ¿quiénes son los sujetos que, en primera persona, pero también como sujetos sociales y colectivos, están ahora en condición de víctimas?

Estas dos maneras de preguntar - la de la víctima que acaso ni siquiera formule la cuestión, pero que padece la negación de su persona; la del que reflexiona y se siente convocado por el dolor del otro -, nos llevan a la exposición de las diversas capacidades humanas identificadas por Ricœur, así como de su contrapartida, los no-poderes, para luego fijarnos en aquella negación que caracteriza la violencia sobre las víctimas. Incluso, aunque no sea objeto de atención aquí, esta reflexión nos pone de frente a la fragilidad propia, así como a la responsabilidad que tenemos al ejercer nuestro poder sobre otro.

Las capacidades a las que alude Ricour son básicamente cuatro: decir o hablar, esto es, designarse como el autor de enunciados propios; actuar, intervenir en el curso del mundo, iniciar un acontecimiento, hacer que algo pase; narrar y narrarse, contar la propia vida y la de otros en tramas que organizan la dispersión de lo vivido en relatos que pueden seguirse, volver a relatarse de modos distintos, con otros sentidos; imputabilidad de una acción, es decir, reconocerse como el autor, el responsable de una acción determinada, que se articula a la capacidad de reconocer el bien o la obligación, de "estimar como buenas o malas, de declarar permitidas o prohibidas las acciones de otros o de nosotros mismos". ${ }^{42}$ Ricœur tratará tam-

42 Ricœur, Le juste, 33. 
bién la capacidad de recordar ${ }^{43}$ que complementa la configuración del ¿quién? como una capacidad de atribuirse recuerdos, de luchar contra el olvido, mucho más cuando éste no es resultado del paso ineluctable del tiempo, sino de poderes extraños que se imponen mediante la violencia o la ideologización. Por último, nos hallamos la capacidad de prometer que supone en primer lugar hacer lo que se promete a otro que se hará, pero que sobre todo concierne a "una voluntad de constancia, de mantenimiento de sí, que pone su sello en una historia de vida enfrentada a la alteración de la circunstancias y a las vicisitudes del corazón. ${ }^{4} 4$

A la capacidad de hablar se opone el silencio, el no poder decir, el no encontrar las palabras adecuadas, el hallarse en situaciones en las que no se sabe qué y cómo proferir un discurso. Por su parte, la víctima pierde la capacidad de decir o hablar cuando es silenciada con la amenaza constante a su vida o a la de su familia. Se le niega la posibilidad de decir su mundo, de llamar por su nombre a los victimarios y a las circunstancias que han propiciado su situación; en últimas, la víctima es testigo de excepción de "la impotencia para decir que resulta de una exclusión efectiva de la esfera lingüística" y corre el riesgo de "creerse incapaz de hablar", de ser "inválido del lenguaje", mutilado. 45

La contrapartida de nuestra capacidad de acción es la pasividad, nuestra no-omnipotencia, el aguijón de la ausencia de fuerzas, de la enfermedad, del desgaste por el paso del tiempo, así como la imposibilidad de calcular completamente los efectos de nuestras acciones. Esta incapacidad se agudiza en el caso de las víctimas, que pierden su capacidad de reconocerse como agentes: se ven obligados a irse de su tierra; no pretenden dejar sus formas de vida asociadas a su

\footnotetext{
43 Ricœur, La mémoire, l'bistoire, l'oubli, 4.

44 Ricour, Parcours de la reconnaissance, 191.

45 Ricœur, Le juste 2, 91.
} 
territorio y de repente se ven empleados en oficios que ni siquiera conocen o que nunca imaginaron, y viviendo de la caridad de un familiar o del escaso subsidio que consiguen en diversos estamentos públicos o privados. ${ }^{46}$

A esta capacidad negada o disminuida de agencia se suman experiencias en las que se crea un ambiente de culpabilización - aneja al rompimiento de mínimos lazos de camaradería y solidaridad - respaldado por el afán, legítimo, claro está, de encontrar responsables, pero que termina viendo en todo otro un sospechoso, presuntamente culpable, o a un enemigo. En otros casos, "los sentimientos de culpa [son] generados por las imágenes y juegos mentales de las probabilidades: si yo no lo hubiera dejado ir, si se hubiera venido antes, etc."; ${ }^{47}$ en otros, los sobrevivientes "todavía hoy deben vivir de forma permanente en la tensa frontera del miedo. Su única culpa es haber quedado vivos; han sido sometidos a no tener rutinas diarias y a no tener proyectos de vida estables. Hasta para entrevistarlos hay que buscar condiciones especiales de seguridad. En su cotidianidad ocupa un lugar central aquello de 'tener un bajo perfil'”. ${ }_{48} \mathrm{Y}$ a ello se suma que el Estado, cuando tendría que reconocer su culpabilidad, sólo "se solidariza" con las víctimas, ${ }^{49}$ una expresión que reduce la grandeza de la solidaridad al juego teatral de sentir lástima, y que

46 En su ensayo "Autonomie et vulnérabilité", Ricœur advierte que la capacidad de acción se ve negada en las formas "de instrumentalización que corrompen las relaciones de servicio entre humanos" (Le juste 2, 91). Sin duda, cuando los apoyos gubernamentales se convierten en una cifra que disfraza o distorsiona las condiciones de las víctimas (escaso ingreso per cápita, insuficiente cubrimiento de servicios básicos, opciones laborales mínimas, traumas ocasionados por la carencia del duelo pertinente) estamos de frente a la instrumentalización de seres humanos que parecen ser funcionales únicamente a los índices que debe cumplir un país como el nuestro, constantemente sometido a la evaluación internacional en materia de derechos humanos.

47 Comisión Nacional de Reconciliación y Reparación - Grupo de Memoria Histórica [CNRR-GMH], La Rochela. Memorias de un crimen contra la justicia (Bogotá: Ediciones Semana, 2010), 232.

48 CNRR-GMH, La Rochela, 238.

49 CNRR-GMH, Bojayá. La guerra sin límites (Bogotá: Ediciones Semana, 2010), 18. 
no se traduce en imputación de cargos ni en juicios a los perpetradores de los crímenes, junto con autores intelectuales, auxiliadores y cómplices, ni en la generación de condiciones efectivas para resarcir el carácter de sujetos de derecho de las víctimas.

En lo concerniente a la memoria - cuyo revés es el olvido - la idea rectora del análisis ricouriano es que ésta "es del pasado". 50 Esto significa que lo recordado: (1) pasó de verdad; (2) ya pasó y (3) permanece. ${ }^{51}$ Lo que pasó pasó de verdad, no puede negarse, echarse para atrás, no se puede torcer el curso de los acontecimientos; sólo queda hacerse cargo. Este hacerse cargo va acompañado del asalto permanente de las imágenes dolorosas que acompañan la vida de los sobrevivientes, testigos excepcionales de los crímenes: "Las víctimas, constituidas en cuanto tales por ese traumatismo, configuran sus recuerdos con imágenes, en imaginación 'ven de nuevo' lo que vieron y vivieron, pero se trata de imágenes que dan cuerpo al recuerdo, no que lo volatilizan haciéndolo imaginario".52 Por su parte, ya pasó hace referencia a que la vida de sus seres queridos no será más, ni sus pies retornarán a la tierra natal, ni recuperarán los vínculos sociales ni los proyectos de vida deseados. Sin embargo, lo que pasó adquiere un carácter presente al seguir repitiéndose en el sueño y el llanto, en el vacío evidente marcado por pequeñas ausencias en las rutinas cotidianas, en el silencio doloroso de sus muertos. La prueba de la realidad hace que muchas víctimas experimenten que fueron disminuidos en su vitalidad, que se acabó la vida también para ellos, todo lo cual es característico de la melancolía en la que "es el yo mismo el propiamente desolado: cae bajo los golpes de su

50 Aristóteles, Parva naturalia, trad. Jorge Serrano (Madrid: Alianza, 1993), $449 \mathrm{~b} 15$.

${ }^{51}$ Xabier Etxeberría, Identidad como memoria narrada y víctimas del terrorismo (Bilbao: Bakeaz, 2009).

52 Ibíd., 5. 
propia devaluación, de su propia acusación, de su propia condena, de su propio abatimiento". 53

Por último, lo que pasó permanece como testimonio de fidelidad: fidelidad de reconocimiento en tanto deber de memoria; fidelidad a los que ya no están, que bien puede relacionarse a la deuda con las promesas incumplidas de los hombres y mujeres que nos precedieron. Desafortunadamente, también pueden permanecer un tipo de promesa pronunciada por los detractores: "volveré", "si no te vas..." "si hablas...", que imposibilitan no solo el tejido de lazos intersubjetivos con los que han sobrevivido, sino cualquier atisbo de compromiso social, político y económico del "Nunca más", todo lo cual impide la restitución de las capacidades.

No obstante, esta promesa que se inscribe en el deber de la memoria tiene que estar atenta a no permitir la "captación de la palabra muda de las víctimas". ${ }^{54}$ Esta captación no sólo arrebata la capacidad de decir que debe agenciar la víctima, sino que le impide a ésta la recomposición de su quién en la confrontación con el otro. No puede haber silenciamiento, así éste se inspire en una consideración respecto a la dificultad de hablar. Ningún trabajo con las víctimas puede amparar la consagración de cualquier tipo de minusvalía.

El peligro de la captación se le atribuye también a los sistemas de poder que pretenden imponer una identidad unívoca mediante etiquetas como "víctima", "desplazado", "marginal", que reducen el “¿quién?” al “¿qué?”. Estas etiquetas, además, corren el peligro de legitimar el orden social injusto si no propenden por el reconocimiento efectivo del carácter de sujeto de derecho que le corresponde a todo ser humano.

En esta misma dirección, Ricœur advierte sobre la "función selectiva del relato", que nos pone de frente a la capacidad de narrarse.

53 Ricœur, La mémoire, l'histoire, l'oubli, 88.

54 Ibíd., 109. 
Todo relato selecciona entre muchos acontecimientos aquello que quiere ser tejido en la trama narrativa. Asimismo, la selección hace parte del deber de memoria, que Ricour considera como el deber de hacer justicia55. Más aún, como lo recuerda Silvia Pierosara, ${ }^{56}$ hay una relación entre la exigencia de ser reconocido y la demanda de ser reconocido, justamente, como narrador [y añadiría, siguiendo el Estudio VI de Sí mismo como otro: protagonista, coautor del sentido] de su propia historia. Pero cuando esa selección está marcada por una estrategia de manipulación política que estipula qué se puede narrar, a quién se le atribuye la responsabilidad y a quién se considera "innombrable", o a quién no puede imputársele delito alguno, la selección se vuelve cómplice de la impunidad y - ¡una vez más! -, del silenciamiento.

\section{4 - Reconocimiento mutuo: escenario de realización de las capacidades}

Si nos atenemos al amplio espectro de las capacidades - que operan en constante imbricación -, cualquier proceso de paz tiene que considerar como uno de sus propósitos centrales que las víctimas recuperen su calidad de sujetos de derecho, esto es, que puedan reconstruir sus proyectos de vida como hombres y mujeres capaces. Esto no se restringe a una restitución de índole económica, sino que implica la recuperación de las capacidades de las víctimas: designarse como emisores de sus enunciados, agentes de sus acciones, narradores de la historia que ellos cuentan sobre ellos mismos; capacidad de oír, entender y asumir las narraciones de los

\footnotetext{
55 Paul Ricœur, Crítica y convicción. Entrevista con François Azouvi y Marc Launay, trad. Javier Palacio (Madrid: Síntesis, 2003), 121.

56 Silvia Pierosara, "Asking for Narratives to be Recognized. The Moral of Histories", Ricour Studies 2, no 1, (2011): 70-83.
} 
victimarios; capacidad de recordar de otro modo, de emprender otras vivencias y ganar otras memorias, de hacer nuevas promesas e incluso capacidad de perdón entendido como don, y no como imposición religiosa o jurídica que opere como el punto de partida de una paz que pretende ser duradera a condición de la amnesia o la impunidad. ${ }^{57}$ Esto es posible si las iniciativas estatales, en conjunto con las de la sociedad civil, apuestan por la configuración de escenarios donde sea posible la restitución de las capacidades humanas. En estos escenarios se asume que el ejercicio de las capacidades requiere aprendizajes individuales y colectivos, pautas compartidas de reconocimiento y ámbitos de desarrollo.

¿Por qué ponemos este énfasis en el Estado y en la sociedad civil? Seguramente como respuesta a la urgencia de la mediación institucional para destrabar, sostener o iniciar trabajos con víctimas que se vienen llevando a cabo a lo largo y ancho del país, cuya mera descripción ocuparía un trabajo independiente. También porque el "detonante", por llamarlo de algún modo, de nuestra investigación fue la Ley de víctimas que compromete al Estado y todas sus instituciones, como al cambio necesario de una sociedad civil a veces cansada, a veces indiferente o a veces temerosa de lo que puede pasar en su seno si tiene que modificar paulatinamente sus modos de ser, de actuar, de juzgar incluso a esos "otros" que parecen ser las víctimas.

Pero también este énfasis cobra sentido si lo examinamos a la luz de los planteamientos de Ricœur. En Parcours de la reconnaissance,

57 Para un análisis riguroso y detallado del problema del perdón en y desde la filosofía ricœuriana, ver: Guilhem Causse, La geste du pardon. Parcours philosophique en débat avec Paul Ricoeur (Paris: Kimé, 2014). Una reflexión más amplia sobre el perdón, a propósito del conflicto colombiano, la hemos desarrollado en: "Sobre el perdón. Una reflexión desde Paul Ricoeur", en Miradas sobre la reconciliación. Reflexiones y experiencias, ed. Jorge Martínez y Fabio Neira (Bogotá: Universidad de La Salle, 2010), 87-96. Y en: "Dolor, narración y memoria", en Pasiones, vicios $y$ virtudes. Una aproximación a las polifonías de los afectos humanos, comp. Luisa Monsalve (Bogotá: Universidad Externado de Colombia, 2013): 47-60. 
Ricœur cierra la exposición de su fenomenología del hombre capaz indicando que las capacidades comienzan a desarrollarse como prácticas sociales, es decir, como "componentes del obrar en común", como "la esfera de las representaciones que los hombres se hacen de sí mismos y de su lugar en la sociedad" 58 y que "contribuyen a la instauración del vínculo social". 59 En otras palabras: en medio de prácticas sociales aprendemos nuestra lengua y, con ella, a nombrar el mundo, a actuar de determinadas formas y a evaluar la bondad, la justicia o la conveniencia de nuestras acciones; son prácticas sociales las que nos enseñan a narrar de determinadas maneras, y a seleccionar trozos de nuestra vida en función de su evaluación retrospectiva y de su proyección futura; asimismo, recordamos según formas enmarcadas socialmente, consagradas en rituales familiares, barriales, nacionales o de otra índole. Así, en el vínculo social se pone en juego más que un mecanismo de asociación con fines egoístas o de mera preservación de la especie; al vincularnos unos con otros, posibilitamos el ejercicio de nuestros proyectos de vida que forzamos a hacer aparecer en la historia.

Si remitimos esta idea concretamente al propósito de que las víctimas vuelvan a ser considerados seres humanos capaces, tendríamos que evitar cualquier ejercicio inspirado en el principio individualista del "cada uno es responsable de su futuro" que circula abierta o discretamente en nuestra sociedad y que ha marcado varios proyectos del gobierno que pretender hacer de los desplazados "pequeños empresarios". Por el contrario, un trabajo con las víctimas, a la vez que ayuda a que cada quien se reconozca como sujeto capaz, se apropie de las condiciones necesarias para hacer su proyecto de vida y luche por la restitución de sus derechos, propende por la restauración de sus lazos y prácticas sociales en

58 Ricœur, Parcours de la reconnaissance, 200.

59 Ibíd., 201. 
medio de los cuales se representaban como hombres y mujeres dignos de estima y respeto, así como por la transformación y apertura del derecho, de las instituciones políticas y de los modos de ser de la sociedad civil.

En suma: sólo en la articulación entre la base antropológica del autorreconocimiento y el reconocimiento mutuo tiene razón de ser la lucha decantada en leyes y sostenida (cuando no suscitada) por diversos colectivos, movilizaciones sociales, ONGs y entes gubernamentales. Sin la institucionalidad, se corre el riesgo de que las demandas por el reconocimiento en contextos problemáticos como el del conflicto armado - y acaso también en el pretendido postconflicto - carezcan de los dientes suficientes para garantizar su cumplimiento; sin el recurso a la base antropológica, acrisolada por la meditación sobre qué es lo justo y lo bueno en el contexto de nuestras sociedades plurales, la aplicación de la ley puede adquirir el cariz de un proceso técnico, que sigue instrumentalizando a las víctimas. Se trata, diremos con Ricœur, de lograr una "estructura dual del reconocimiento jurídico" que "consiste... en la conexión entre la ampliación de la esfera de los derechos reconocidos a las personas y el enriquecimiento de las capacidades que estos sujetos se reconocen". 60

${ }^{60}$ Ibíd., 288-289. Queda para una discusión posterior la crítica que hace Taylor según la cual "mientras en sus últimos trabajos Ricœur reconoce el conflicto entre universalismo y contextualismo, él concede demasiado al papel de lo universal en normas de ética y justicia" (George Taylor, "Ricœur versus Ricœur? Between the Universal and the Contextual", en From Ricœur to Action. The Socio-Political Significance of Ricour's Thinking, eds. Todd Mei y David Lewin (New York: Continuum Books, 2012), 136. La discusión enriquecería no sólo los estudios sobre Ricœur, sino las disputas en torno a cómo implementar leyes mediante las cuales se atienda a la particularidad de cada caso que involucre víctimas, al mismo tiempo que se mantiene vigente la posibilidad de la garantía de sus derechos a largo plazo, toda vez que aún no arribamos al "Nunca más" que ponemos en el horizonte de nuestras luchas políticas. 


\section{5 - La formación del sujeto. El lugar de la atestación}

El último tramo de nuestro recorrido no está dedicado a presentar en detalle las problemáticas epistémicas, antropológicas, éticas e incluso políticas que atraviesan toda la atestación como pieza clave de la hermenéutica del sí, especialmente desarrollada por Ricœur en Soi-même comme un autre. La cuestión que intentamos explorar aquí es más bien la siguiente: ¿qué tipo de sujeto se requiere para un trabajo con las víctimas como el que hemos apenas esbozado? Por supuesto no nos referimos al tipo de profesionales, o a las características físicas, psicológicas, culturales o de otro tipo que deben tener los equipos comprometidos directamente con el trabajo que exige tanto la aplicación de la Ley como todo aquello que contribuiría directamente a la restitución de las capacidades de las víctimas. Cuando discutimos las primeras versiones de este texto y ahora que lo damos a conocer, pensamos más bien en los sujetos que somos nosotros mismos, estudiantes, profesionales de las humanidades o profesores. Podríamos decir incluso que la pregunta apunta a qué tipo de sujeto se requiere formar para la convivencia con las víctimas del conflicto.

Comencemos anotando que la atestación es presentada por Ricour como "seguridad de ser uno mismo agente y paciente" ${ }^{61}$ Esta "seguridad" de la que se habla aquí, recordarán los lectores familiarizados con Soi-même comme un autre, es más bien la del modo mediante el cual podemos dar cuenta de nuestro ser en el mundo, de nuestras capacidades y también de nuestros no-poderes. En otras palabras: cuando hablo, actúo, me narro, me imputo la responsabilidad de mi acción, recuerdo y prometo atesto en cada caso el quién que soy, el quién que proyecto ser.

61 Ricœur, Soi-même comme un autre, 35. 
Pero como no hay sí mismo sin otro - pieza clave de la filosofía práctica ricœuriana - también me atesto como sujeto en el momento en que mis propios puntos de vista, proyectos, planes, ideales, se ponen frente a otros, tanto a los otros de las relaciones cercanas como los otros de las relaciones sociales más amplias; a esto se suma que mis puntos de vista se ven confrontados con los puntos de vista más decantados y estables de la sociedad, así como con un marco simbólico de normas, y también con el ámbito del derecho. Aquí Ricœur define la atestación como la "capacidad de yuxtaponer los puntos de vista personales e impersonales con respecto a la propia vida". ${ }^{62}$ En otras palabras: entre lo que quiero y lo que puedo, entre lo que quiero y me es permitido atesto mi capacidad de desarrollar mis proyectos de vida.

No solo tenemos estos dos "modos" en los que atestamos nuestro sí, sino que hay un tercer modo que puede resultar más exigente. Digamos que existen situaciones en las que mis proyectos y la sociedad en la que vivo no entran en contradicción, sino que pareciera que se enriquecen mutualmente. Pero Ricour suele remarcar situaciones en las que debemos responder por nosotros mismos y por los otros, en las que no está del todo claro lo que ha de hacerse, en las que hay incluso contradicciones entre nuestros propios proyectos o entre dos normas que, en otras ocasiones, conviven sin problemas en la sociedad. Aquí la atestación, dice el francés, es "la certeza según la cual, en esta situación, esta decisión es la mejor, lo único que hay que hacer". 63

El énfasis pareciera estar puesto siempre en el sí mismo: primero ante sus propias capacidades, luego sometido a las exigencias de las relaciones con otros y luego ante situaciones de difícil resolución en las que tiene que decidir. Sin embargo, volvemos a decir que no

\footnotetext{
62 Ibid., 79.

63 Ibid., 82.
} 
se entiende la filosofía ricœuriana si no se considera el doble movimiento que va del sí al otro y del otro al sí, doble movimiento en el que es posible la atestación de nosotros mismos. Este movimiento no solo concierne a una declaración de la necesidad - de algún modo "inevitable", por así decirlo - de que los otros estén de algún modo en mi vida desde mi concepción hasta mi muerte, sino sobre todo a una íntima invitación mutuamente lanzada a responder por el otro, que procede de las entrañas de nuestro modo de ser, pues la alteridad "no se añade desde el exterior a la ipseidad, como para prevenir su derivación solipsista, sino que pertenece al tenor de sentido y a la constitución ontológica de la ipseidad". 64

En relación con la problemática de las víctimas del conflicto colombiano, digamos que el hecho - convertido ya en lugar común y no por ello falso - de que un alto porcentaje de colombianos tenemos un familiar, un conocido, un amigo o un vecino que ha sido víctima del conflicto armado (cuando no lo hemos sido nosotros mismos), constituye un desafío que no puede dejar quieto al pensamiento ni a la acción. Y más allá de esta consideración acaso meramente estadística, tendremos que asumir en serio que la víctima es quizás el otro-otro, el otro que desafía esta especie de modo de ser mortífero instalado en la sociedad. ${ }^{65} \mathrm{~A}$ riesgo de caer en una generalidad, diríamos que signos de este modo mortífero de ser los hallamos en la costumbre de la muerte, en el alto umbral de maltrato que podemos soportar antes de indignarnos y actuar consecuentemente, en la corrupción de las instituciones, en la práctica de la justicia que se compra con dinero, y un largo etcétera. ¿Qué significa atestarnos en un contexto semejante? Ricœur resalta una forma particular de atestación del sí según la cual decir "aquí estoy" significa sobreponerse al hecho de estar constituido por las aberraciones de la historia, cuyos efectos, si

64 Ibíd., 367.

65 Ricœur, Soi-même comme un autre, 298. 
bien no son dominados por una conciencia individual que pretende enseñorearse sobre el sentido, tampoco pueden ser una mordaza para la resistencia interior. Esto, sin embargo, nada tiene que ver con el heroísmo moral de unos pocos elegidos, ni con la indiferencia, sino con una imaginación creadora capaz de proyectar sobre lo que hay, precisamente porque lo ha vivido y reflexionado, la posibilidad de una nueva manera de habitar el mundo. En esta nueva manera, frágil y necesitada siempre de nuevos respaldos institucionales, el sujeto está llamado a responder de sí, por otros y con otros.

Asimismo, la atestación es la forma en que cada quien como sujeto capaz da cuenta de sí mismo respondiendo al llamado del otro, respuesta que acontece en la asunción para mí, en primera persona, de la voz del otro que dice: “No matarás!”, "hasta el punto de convertirse en mi convicción, esa convicción que iguala el acusativo del "¡Heme aquí!" al nominativo del "Aquí estoy”. 66 Dicho de otro modo, lo que atrás citábamos de Reyes Mate ${ }^{67}$ asume la figura de una responsividad en la que doy testimonio de mi condición de sujeto capaz en la relación con el otro a quien le ha sido negada su humanidad. "Aquí estoy" dice también "aquí respondo" a situaciones que me generan indignación, cuyo punto más sensible "concierne al contraste insoportable... entre la atribución igualitaria de derechos y la distribución desigual de bienes en sociedades como las nuestras, que parecen condenadas a pagar el progreso como productividad en todos los campos por un incremento sensible de las desigualdades". ${ }^{6}$

${ }^{66}$ Ibíd, 391. La expresión "aquí estoy" es tomada de Gen 22, 1 y 1 s 3,4, que suele citar Levinas en Totalité et infini.

67 "Sólo hay sujetos morales cuando la relación es simétrica, pero hasta llegar ahí los dos sujetos necesitan el reconocimiento del otro, aunque no de la misma manera. Aquí debe (en el sentido de deuda y de obligación) más quien más tiene”.

68 Ricœur, Parcours de la reconnaissance, 292. 
Sentirnos concernidos por las víctimas no es [sólo] una temática, un problema teórico, o un problema político, sino una "respuesta moral" al atentado contra la dignidad de otros que obliga a que cada quien, como sujeto capaz, se sienta partícipe (obligado, impelido, convocado) del "proceso de ampliación de la esfera de los derechos subjetivos", de suerte que asuma esta convicción: "la responsabilidad en cuanto capacidad para responder de sí mismo es inseparable de la responsabilidad en cuanto capacidad para participar en una discusión razonable sobre la ampliación de la esfera de los derechos, sean civiles, políticos o sociales. El término responsabilidad abarca, pues, la aserción de sí y el reconocimiento del mismo derecho del otro a contribuir a los avances del derecho y de los derechos". 69

Asumir una tal responsabilidad tiene que ver con la educación política en el seno de la ya frágil sociedad civil. Y no puede hacerse al margen de un diálogo con las ciencias sociales, al mismo tiempo que con la pluralidad de voces de la sociedad, que nos permita entender un contexto como el colombiano - así como orientar nuestras acciones en él - inserto en una red de relaciones históricamente constituidas que opera como una máquina de producción de víctimas, en una lógica que calcula su progreso a costa del sacrificio de seres humanos prescindibles; de escandalosa distribución de la tierra, reducción del campesino a pequeño productor cuyo trabajo jamás logra competir con las multinacionales o debe ponerse a su servicio; de empobrecimiento y expropiación hecha por vías legalmente protegidas; de abandono del papel estatal en materia de salud, educación o servicios públicos, entre otras prácticas que están en los tuétanos del Estado y de la sociedad.

En esta tensión entre el deseo de vida buena articulada a la consecución de relaciones intersubjetivas de reconocimiento y en

69 Ibíd., 293. 
instituciones justas, ${ }^{70}$ se realiza una forma de atestación que hunde sus raíces en lo que Ricœur denomina "el principal problema de la democracia: ¿cómo educar en la adhesión crítica a unos ciudadanos que se encuentran en la situación de no alcanzar nunca a generar por sí mismos lo político?".71 Dicho de otro modo, atestar el sí mismo es mantener viva - si es que, en algunos casos, no hay que decir: iniciar - la responsabilidad histórica que tenemos como sujetos encarnados, que habitamos el mismo mundo de la vida y en el cual nos las tenemos que ver con nuestra propia finitud, de "participar en el proceso de ampliación de los derechos subjetivos",72 a lo que habría que añadir: de nuestros derechos económicos, sociales y culturales. Es fomentar "la capacidad, reconocida a la vez por la sociedad y por sí mismo... [de] pronunciarse de una manera racional y autónoma sobre cuestiones morales". ${ }^{73}$ En fin, asumir que la responsabilidad como capacidad para responder de sí mismo es inseparable de la responsabilidad a la que nos invita la configuración de una sociedad, de una cultura, de un sistema económico que detenga su carrera de producir seres humanos prescindibles.

\section{Bibliografía}

Almanza, Tulia; William Rojas; Giovanni Púa y Manuel Prada. Ciudadanía e identidad frente a las víctimas. La configuración de la ciudadanía en Colombia. Informe final de investigación. Bogotá: Universidad de San Buenaventura - Facultad de Filosofía, 2012.

70 "Mi deseo de vivir en instituciones justas es correlativo de la atestación de que yo soy capaz de este deseo de vivir bien que me distingue ontológicamente de los demás seres naturales" (Ricour, Le juste 2, 78).

${ }^{71}$ Ricœur, Crítica y convicción, 142.

72 Ricœur, Parcours de la reconnaissance, 293. Sugerimos ver nuestro trabajo: Alexander Ruiz y Manuel Prada, La formación de la subjetividad política. Estrategias y recursos para el aula (Buenos Aires: Paidós, 2012), especialmente la primera parte.

73 Ricœur, Parcours de la reconnaissance, 293. 
Aristóteles. Parva naturalia. Traducido por Jorge Serrano. Madrid: Alianza, 1993.

Benjamin, Walter. Tesis sobre la historia y otros fragmentos. Traducido por Bolívar Echevarría. Bogotá: Desde abajo, 2010.

Comisión Histórica del Conflicto Armado y sus Víctimas. Contribución al entendimiento del conflicto armado en Colombia. Bogotá: Comisión Histórica del Conflicto Armado y sus Víctimas, 2015, documento de trabajo, en línea: http://www. altocomisionadoparalapaz.gov.co/oacp/Pages/informes-especiales/resumen-informe-comision-historica-conflicto-victimas/el-conflicto-y-sus-victimas.aspx.

Comisión Nacional de Reconciliación y Reparación - Grupo de Memoria Histórica. La Rochela. Memorias de un crimen contra la justicia. Bogotá: Ediciones Semana, 2010.

Comisión Nacional de Reparación y Reconciliación - Grupo de Memoria Histórica. Bojayá. La guerra sin límites. Bogotá: Ediciones Semana, 2010.

Etxeberria, Xabier. Identidad como memoria narrada y víctimas del terrorismo. Bilbao: Bakeaz, 2009.

Gabriel, Silvia. "Razón práctica y violencia en Paul Ricœur". Dianoia LVI, n 66 (Mayo 2011): 59-79.

Jervolino, Domenico. "El cogito herido y la ontología del último Ricœur" en Fenomenología por decir. Homenaje a Paul Ricœur, editado por Patricio Mena, 65-80. Santiago de Chile: Universidad Alberto Hurtado, 2006.

Pierosara, Silvia. "Asking for Narratives to be Recognized. The Moral of Histories". Études Ricoeuriennes / Ricoeur Studies 2, n. ${ }^{\circ} 1$ (2011): 70-83.

Prada, Manuel. "Dolor, narración y memoria", en Pasiones, vicios y virtudes. Una aproximación a las polifonías de los afectos humanos, compilado por Luisa Monsalve, 47-60. Bogotá: Universidad Externado de Colombia, 2013.

Prada, Manuel. "Sobre el perdón. Una reflexión desde Paul Ricœur" en Miradas sobre la reconciliación. Reflexiones y experiencias, compilación de Jorge Martínez y Fabio Neira, 87-96. Bogotá: Universidad de La Salle, 2010.

Prada, Manuel. Entre disimetría y reciprocidad. El reconocimiento mutuo según Paul Ricœur. Bogotá: Aula de Humanidades - Editorial Bonaventuriana, 2017.

Ralón, Graciela. "Violencia e historia". Investigaciones fenomenológicas. Número monográfico: Fenomenología y política, n. ${ }^{\circ} 3$ (2011): 408-417.

Reyes Mate, Manuel. La razón de los vencidos. Barcelona: Ánthropos, 2008.

Ricœur, Paul. "Capacités personnelles et reconnaissance mutuelle" en Anthropologie philosophique. Écrits et conférences 3, de Paul Ricœur, 445-451. Paris: Seuil, 2013.

—_. "Le paradoxe politique" en Histoire et vérité, 294-321. Paris: Seuil, 1967.

- Crítica y convicción. Entrevista con François Azouvi. Traducido por Javier Palacio. Madrid: Síntesis, 2003.

—. La mémoire, l'histoire, l'oubli. Paris: Seuil, 2000.

—. Le juste 2. Paris: Esprit, 2001.

—. Le juste. Paris: Esprit, 1995.

—. Parcours de la reconnaissance. Trois études. Paris: Stock, 2004. 
—. Soi-même comme un autre. Paris: Seuil, 1990.

—. Temps et récit. 3. Le temps raconté. Paris: Seuil, 1985.

Rodríguez Ávila, Sandra. "Formación de maestros para el presente: memoria y enseñanza de la historia reciente”. Revista Colombiana de Educación 64 (2011): pp. 165-188.

—. "Enseñanza y aprendizaje de la historia en Colombia 1990-2011", en La investigación en la enseñanza de la historia en América Latina, coordinado por Sebastián Plá y Joan Pagés, 109-154. México: Bonilla Artigas Editores, 2014.

Ruiz, Alexander. Nación, moral y narración. Imaginarios sociales en la enseñanza y el aprendizaje de la historia. Buenos Aires: Miño y Dávila, 2011.

Ruiz, Alexander y Manuel Prada. La formación de la subjetividad política. Estrategias y recursos para el aula. Buenos Aires: Paidós, 2012.

Taylor, George. "Ricœur versus Ricœur? Between the Universal and the Contextual" en From Ricœur to Action. The Socio-Political Significance of Ricœur's Thinking, edición de Todd Mein y David Lewin, 136-154. New York: Continuum Books, 2012.

Wall, John. "Moral Meaning. Beyond the Good and the Right" en Paul Ricoeur and Contemporary Moral Thought, de John Wall, William Schweiker y David Hall, 47-63. Londres: Routledge, 2002.

Financiación: Este ensayo se realizó como parte del proyecto de investigación "Ciudadanía e identidad ante las víctimas. Configuración de ciudadanía en Colombia” llevado a cabo en la Universidad de San Buenaventura, Oficina de Investigaciones, (Bogotá, Colombia), 2010-2011. 


\title{
LOS LÍMITES DEL PERDÓN RICAURIANO DESDE LA PERSPECTIVA ARGENTINA
}

\author{
THE LIMITS OF RICAEUR'S CONCEPT OF FORGIVENESS \\ FROM AN ARGENTINIAN PERSPECTIVE
}

Esteban Lythgoe

UADE - CONICET, Argentina ${ }^{1}$

Resumen: El presente capítulo contrapone dos modelos de perdón: uno bipolar y otro monopolar, e identifica la propuesta ricœuriana con el primero de ellos. Nuestra hipótesis es que, pese a presentar al perdón sólo como una relación moral entre dos individuos, también incluye un objetivo político: la reconciliación nacional. Esta hipótesis se funda en el ejemplo seleccionado para poner de manifiesto los beneficios del perdón y el antecedente hegeliano en el que se basa el desarrollo del perdón. La imposibilidad de un perdón colectivo, nos llevará a postular que la reconciliación social es el resultado indirecto del perdón individual. Concluiremos remitiéndonos a un ejemplo de la historia transicional de la Argentina reciente para ilustrar ciertos aspectos que fueron desapercibidos por

${ }^{1}$ Esteban Lythgoe, Centro de investigaciones filosóficas, Miñones 2073, C1428ATE Ciudad Autónoma de Buenos Aires, Argentina. Mail: estebanlythgoe@yahoo.com.ar 
Ricœur. Este ejemplo nos llevará a sostener que este modelo de perdón, termina beneficiando a los culpables de crímenes de estados en detrimento de sus víctimas.

Palabras clave: Hegel; legitimador; perlaboración; reconciliación; rehabilitación

Abstract: This article contrasts two models of forgiveness: one that is bipolar and another that is monopolar, and characterizes the ricœurian proposal on this topic as being similar with the first model. Our hypothesis is that, in spite of presenting forgiveness only as a moral relationship between two individuals, it also includes a political objective: national reconciliation. This hypothesis is based on the selected example to demonstrate the benefits of forgiveness and the Hegelian background in which the development of forgiveness is based. The impossibility of a collective forgiveness leads us to suggest that social reconciliation is the indirect result of individual forgiveness. In the conclusion of this paper we will refer to an example of Argentina's recent transitional history to illustrate certain aspects that were not noticed by Ricœur. This example will lead us to argue that Ricour's model of forgiveness, ends up benefiting those guilty of crimes of state at the expense of their victims.

Keywords: Hegel; legitimizing; perlaboration; reconciliation; rehabilitation. 


\section{Perdón en el marco de la justicia transicional y la memoria traumatizada}

Derrida sostiene que en las últimas décadas el interés por el perdón ha estado más vinculado con la política que con la ética, ${ }^{2}$ debido fundamentalmente al auge por los estudios de la memoria traumatizada y la justicia transicional. A partir de la década del ochenta varios estados concluyeron extensos y sangrientos años de violencia estatal. Los gobiernos entrantes organizaron comisiones investigadoras sobre los destinos de víctimas de los crímenes de sus respectivos estados y evaluaron distintas estrategias para capear el proceso de transición que enfrentarían, mediando entre el mantenimiento de una precaria gobernabilidad y la aspiración de justicia y verdad. Hubo varios intelectuales, que interesados en las problemáticas ético-políticas, reflexionaron sobre las experiencias logradas en estos procesos, en general, y el recurso al perdón como vía para lograr una reconciliación nacional, en particular. Paul Ricœur no ha escapado a este interés y en sus últimas obras también ha tratado al perdón y su relación con la historia de acontecimientos traumáticos recientes. De hecho, pese a la extensión de su obra, esta temática recién es tratada a partir de 1990. En este sentido, resulta ilustradora la observación de Olivier Abel, según la cual el perdón es una temática marginal dentro de la ética del filósofo francés, que "... recién aparece explicita y metodológicamente desarrollada en el epílogo de La memoria, la historia, el olvido."3

Nuestra intención en las próximas páginas es, en primer lugar, presentar al perdón tal como la propone Ricœur, en el marco de su

\footnotetext{
2 cf. Derrida, El siglo y el perdón, 7-8.

3 Abel, L'éthique du pardon chez Paul Ricour.
} 
diálogo con Jaspers, Hegel, Arendt, Derrida y Abel. ${ }^{4}$ Nuestra hipótesis es que, pese a que Ricœur presenta al perdón sólo como un problema ético entre dos individuos, también incluye una finalidad de corte político: la reconciliación nacional. Esta hipótesis se funda en el ejemplo seleccionado para poner de manifiesto los beneficios del perdón y el antecedente hegeliano en el que se basa el desarrollo del perdón. Este último punto nos llevará a tomar distancia de la tesis de Badiou ${ }^{5}$ de que la base de toda la argumentación de Ricœur es la religión. Aun coincidiendo en la existencia de premisas religiosas dentro de la argumentación, consideramos que el perdón está asociado con su interés en sus últimos años por el reconocimiento. Habiendo determinado un objetivo individual y uno colectivo del perdón, concluiremos este capítulo remitiéndonos a un ejemplo de la historia transicional de la Argentina reciente para ilustrar ciertos aspectos que fueron desapercibidos por Ricœur. Este ejemplo nos llevará a sostener que el modelo ricœuriano de perdón, termina beneficiando a los culpables de Crímenes de Estado en detrimento de sus víctimas.

\section{La caracterización ricœuriana del perdón}

Aunque no se lo afirme explícitamente, en La memoria, la bistoria, el olvido se contraponen dos modelos de perdón diferentes, uno

\footnotetext{
${ }^{4}$ Nuestro capítulo se centra en el debate que lleva a cabo Ricoeur con sus contemporáneos, pero resulta interesante el contrapunto que se puede hacer sobre la temática de la falta y el perdón con Nietzsche en la Genealogía de la moral. Aunque Ricoeur no lleve a cabo explícitamente ese diálogo en el capítulo abordado, la presencia del autor de Las consideraciones intempestivas es manifiesta en La memoria, la historia, el olvido. Para el tratamiento del diálogo entre ambos autores sobre este tema, cf. Polivanoff, "Historia, olvido y perdón. Nietzsche y Ricoeur: apertura de la memoria y el olvido a la vida."

5 Badiou, "The Subject supposed to be a Christian: On Paul Ricœur's Memory, History, Forgetting".
} 
que podemos denominar "monopolar", y otro, "bipolar". El primero de estos modelos es defendido por Derrida en El siglo y el perdón. Allí el perdón es caracterizado como una facultad o posibilidad humana excepcional o extraordinaria, que interrumpiría el curso ordinario de la temporalidad histórica ${ }^{6}$ Entre otras particularidades, el filósofo argelino lo presenta como fin en sí mismo, fuera de toda lógica de intercambio, por lo que, quien lo conceda lo debe hacer de manera gratuita, incluso a quienes no se arrepienten ni lo piden. ${ }^{7}$ Con otras palabras, no hay intercambio alguno: el que perdona dona algo, aun cuando quien lo afectó lo desconozca o haya muerto.

Ricour adelanta el segundo modelo en su interludio a Si mismo como otro. ${ }^{8}$ Allí afirma que Hegel, tras haber descripto la naturaleza de la tensión entre Antígona y Creonte como "...la estrechez de perspectivas del compromiso de cada uno de los personajes.", 9 propone al perdón bipolar como vía para su conciliación. En líneas generales, en la Fenomenología del espíritu se sostiene que, sólo se habría podido lograr que ambos protagonistas de la tragedia de Sófocles hubiera sobrevivido, si ambos hubieran podido renunciar

${ }^{6}$ Cf. Derrida, Op. Cit., 12 y 17.

${ }^{7}$ En este punto Derrida presenta el argumento de que, si el perdón dependiera del arrepentimiento del culpable, se estaría concediendo el perdón a otra persona que la que cometió el crimen. Esta persona “... no es ya decididamente el culpable sino ahora otro, y mejor que el culpable. En esa medida, y con esta condición, no es ya al culpable como tal a quien se perdona." (Derrida, Op. Cit., 15). Badiou, "The Subject supposed to be a Christian: On Paul Ricœur's Memory, History, Forgetting" y Delpech, "La doble adscripción de la memoria como supuesto para 'desatar", recurren a este argumento como crítica al perdón de Ricœur. Belvedresi, "Consideraciones acerca de la memoria, el olvido y el perdón a partir de los aportes de P. Ricœur" también tomará distancia de la bipolaridad de la propuesta ricœuriana sosteniendo una posición similar a la de Derrida, y la que defenderemos al final del capítulo ("No estoy segura de que el hecho de que el ofensor muestre arrepentimiento y pida perdón sea una condición indispensable del perdonar. Me inclino más bien a creer que el perdón es un gesto desinteresado del lado de la víctima, que puede ser incluso independiente de la aplicación de justicia." - Belvedresi, Op. Cit., 206).

8 Cf. Ricœur, Sí mismo como otro, 260-270. También vuelve sobre la cuestión del perdón en el décimo estudio, cf. Ricœur, Op. Cit., 381-3.

9 Ricour, Op. Cit., 263. 
a sus posiciones particulares. En esta obra el perdón es descrito como una relación de reciprocidad que posibilita la reconciliación a través de la renuncia de las parcialidades mutuas de quienes se encuentran en conflicto.

Nuestro autor rechaza toda propuesta hiperbólica, como la de Derrida, para quien "cada vez que el perdón está al servicio de una finalidad, aunque ésta sea noble y espiritual (liberación o redención, reconciliación, salvación), cada vez que tiende a restablecer una normalidad (social, nacional, política, psicológica) mediante un trabajo de duelo, mediante alguna terapia o ecología de la memoria, entonces el "perdón" no es puro, ni lo es su concepto."10 En su lugar recurre al estudio de Mauss sobre el don ${ }^{11}$ a fin de "... recuperar la dimensión recíproca del don en contra de una primera caracterización como unilateral."12

Dicho análisis pone de manifiesto la gran generosidad del donatario, cuyo gesto sería vista como derrochadora, desde una perspectiva mercantil. Sin embargo, no se trata de dar sin esperar nada a cambio: hay una lógica de intercambio diferente a la del dar y devolver, que se la caracteriza como la de dar y recibir. El don exige una respuesta: "el mandato de amar a sus enemigos comienza por quebrar la regla de reciprocidad, al exigir lo extremo; fiel a la retórica evangélica de la hipérbole, el mandato querría que sólo fuera justificado el don hecho al enemigo, del que, por hipótesis, no se espera nada a cambio. Pero, precisamente, la hipótesis es falsa: del amor se espera precisamente que convierta al enemigo en amigo."13

\footnotetext{
10 Derrida, Op. Cit., 12.

11 Mauss, Ensayo sobre el don. Forma y función del intercambio en las sociedades arcaicas.

12 Ricœur, La memoria, la bistoria, el olvido, 612.

13 Ricœur, Op. Cit., 616.
} 
Frente a la posibilidad de que la horizontalidad del intercambio lleve a la suposición de la existencia de una reciprocidad entre ambas partes, se enfatiza el abismo vertical existente entre cada uno de los polos, deteniéndose en aquellos atributos en las que se funda esta cesura. El primero de los polos, la falta, ya había sido tratado de manera tangencial en la tercera parte de esta obra. Allí, desde la perspectiva heideggeriana de la deuda, se hacía abstracción del componente moral, para limitarse sólo a la problemática temporal. ${ }^{14}$ En este epílogo, en cambio, se incorpora la cuestión moral. En lugar de detenerse en las consecuencias que la falta tiene en sus víctimas, su interés gira en torno a los efectos que la falta tiene en el agente del acto. El análisis comienza con la confesión, como instancia donde el agente se hace responsable de su acto, y evalúa, desde una perspectiva "metafísica", los motivos por los que la falta paraliza el poder obrar del culpable. ${ }^{15}$

Cuando se vincula la falta con el mal de la manera propuesta por Jean Nabert, ${ }^{16}$ se puede explicar los motivos por los que la capacidad del culpable se encuentra limitada. ${ }^{17}$ La remisión al mal posibilita asociar la experiencia de la falta con la del fracaso, en tanto ineficacia de lo realizado, y con la de la soledad, como ruptura de toda comunicación recíproca. La relación de la falta con lo

\footnotetext{
${ }^{14}$ Cf. Ricœur, Op. Cit., 468-9: "El vínculo entre futuridad y paseidad es garantizado por un concepto puente, el de ser deudor. ... Pienso que la idea de falta debe recuperar su lugar en una fase bien precisa del juicio histórico, cuando la comprensión historiadora es enfrentada a daños probados: la noción de daño hecho a otro preserva entonces la dimensión propiamente ética de la deuda, su dimensión culpable. ... Pero antes es bueno disponer del concepto moralmente neutro de deuda que no diga más que el de herencia transmitida y que hay que asumir, lo que no excluye inventario crítico."

15 Cf. Ricœur, Op. Cit., 585: "La cuestión ahora planteada trata de otro enigma distinto del de la representación presente de una cosa ausente marcada con el sello de lo anterior. Es doble: el enigma de una falta que paralizaría el poder obrar de este 'hombre capaz' que somos; y, como réplica, el de la eventual suspensión de esta incapacidad existencial designada por el término perdón."

16 Jean Nabert, Ensayo sobre el mal.

17 Cf. Ricœur, La memoria, la historia, el olvido., 591-3.
} 
injustificable, por su parte, explica el sufrimiento de sus víctimas y la degradación de su agente. El agente en este estado entra en contacto "... con un impedimento interior, con una impotencia radical para coincidir con un modelo de dignidad, al mismo tiempo que con un frenesí de compromiso en la acción cuya medida apenas la da el odio, y que hace estallar la idea misma de afección de sujeto por sus propias acciones." 18

La confesión, por su parte, es caracterizada como un tipo de imputación, en la que la reflexión se atribuye a sí un acto. La diferencia clave con la adscripción, empero, es el componente moral presente cuando el sujeto autoexaminado asume una acusación y se hace cargo de la falta, y se autodesigna "culpable". Este reconocimiento lleva a que el sí asuma el componente activo de obrar mal y el pasivo de haber sido afectado por la propia acción. Ricœur no llega a enfatizar suficientemente la importancia moral de la confesión en tanto incorpora al culpable en el reino de la moral, precondición necesaria para el perdón. Jaspers observa, en nuestra opinión atinadamente, que no a todos se les puede predicar la culpa moral. En su libro sobre la culpa, este autor distingue entre aquella pequeña minoría que planificó y llevó a cabo los crímenes de estado, de aquellos que cometieron "... un error culpable, tanto si se encubrieron cómodamente lo que sucedía o se adormecieron y se dejaron seducir o comprar para obtener ventajas personales cuanto si obedecieron por miedo."19 Dado que la culpa moral está ligada con una capacidad reflexiva, lo criminales carecerían de este tipo de culpa por ser incapaces de arrepentirse. Los segundos, en cambio, sí lo son, pues son aquellos pasibles al arrepentimiento y la confesión. ${ }^{20}$

\footnotetext{
18 Ricour, Op. Cit., 593.

19 Jaspers, El problema de la culpa, 82.

20 Cf. Jaspers, El problema de la culpa, 82: "Hitler y sus cómplices, esa pequeña minoría integrada por una decenas de miles de personas, se encuentran libres de culpa moral mientras no se percaten de ella. Parecen incapaces de arrepentimiento
} 
La experiencia de la falta es un hecho para la reflexión, el "hay perdón”, también. Este simple planteo aleja a Ricœur respecto de autores como Hartmann, ${ }^{21}$ que rechazan su posibilidad. "Si el perdón fuera posible, afirma, constituiría un mal moral, que pondría la libertad humana a disposición de Dios y ofendería la dignidad humana." 22 Este polo será caracterizado por dos aspectos. En coincidencia con Derrida, el primero consiste en señalar su origen en las religiones judía, cristiana y musulmana. Ambos autores disienten respecto a los motivos por los que su uso se ha generalizado, a punto de que está habiendo casos resonantes de perdón en países con tradiciones completamente diferentes a la abrahámica. Mientras Derrida lo asocia con una suerte de banalización de dicho concepto con finalidades geopolíticas, ${ }^{23}$ Ricœur insinúa motivos de carácter extra históricos y políticos que podrían justificar su globalización, y que sus investigaciones pretenden revelar. ${ }^{24}$

En el marco de esta consideración resulta pertinente volver hacia la crítica de Badiou. Este editor de La memoria, la historia, el olvido calificó a Ricour de hipócrita por haber ocultado la raíz cristiana que se encuentra a la base de su argumentación: "Mi crítica principal, en el fondo, apunta a lo que considero menos como una hipocresía que como una falta de civilidad, y que es común a tantos fenomenólogos cristianos: la absurda disimulación de la fuente verdadera

y transformación. Son como son. ... Hay culpa moral en todos aquellos que dejan espacio a la conciencia y al arrepentimiento. Son moralmente culpables las personas capaces de expiación, aquellos que supieron o pudieron saber y que, sin embargo, recorrieron caminos que ahora, en el autoexamen, estiman como un error culpable.

${ }^{21}$ Nicolai Hartmann, Ética.

22 Ricour, Op. Cit., 595.

23 Cf. Derrida, Op. Cit., 11-2.

${ }^{24}$ Cf. Ricœur, Op. Cit., 597: "Esta simple observación plantea el gran problema de las relaciones entre lo fundamental y lo histórico para cualquier mensaje ético con pretensión universal, incluido el discurso de los derechos del hombre." 
de las construcciones conceptuales y de las polémicas filosóficas." 25 François Dosse defiende a Ricœur, señalando la contradicción en la que cae Badiou, por basar, por una parte, sus planteos en la tesis de que "...los creyentes no tiene derecho de ciudadanía en el mundo de la filosofía..." ${ }^{26}$ y haber reconocido, por la otra, la existencia de un diálogo riguroso con Ricœur acerca del cristianismo, al que considera como un tema central para la actualidad. El historiador refuerza su defensa señalando la meticulosidad ricouriana de no confundir el plano religioso del filosófico, pese a su reconocida convicción religiosa. En mi opinión, las respuestas de Dosse no son suficientemente contundentes frente al embate de Badiou. Con respecto a la primera observación, es posible sostener sin contradicción alguna que el cristianismo es una problemática importante a ser debatida desde una perspectiva sociológica, política, antropológica e, incluso, conceptual, sin por ello aceptar la posibilidad de una filosofía cristiana. En segundo lugar, por más reconocida que sea la capacidad de Ricœur de deslindar lo filosófico de lo religioso, eso no quita el carácter explícitamente religioso de un punto tan nodal para la posibilidad del perdón como la afirmación de que el desacomplamiento entre el sujeto moral y sus acciones “... expresa un acto de fe, un crédito otorgado a los recursos de regeneración del sí." 27 También resulta religiosa la tesis de que la confianza en esta tesis descansa en última instancia en las religiones del Libro. Ahora bien, en la medida en que estas tesis son explícitamente religiosas, pierde sentido la carátula de hipócrita. Esto no levanta la duda de si se puede hacer filosofía desde el cristianismo. Sin embargo, considero que el hecho mismo de que el perdón, por más banalizado que pueda llegar a estar, tenga un origen religioso habilita a que se

\footnotetext{
25 Badiou, Op. Cit., 27.8.

26 Dosse, Paul Ricour. Les sens d'une vie (1913-2005), 667.

27 Ricœur, Op. Cit., 628.
} 
recurra a ese origen para resolver sus paradojas. A esto le debemos agregar, finalmente, que el carácter que tienen estos aportes es, en última instancia, de atestación, ${ }^{28}$ lo cual deja abierta la fuente epistémica de donde pudo surgir esta afirmación.

El segundo aspecto que caracteriza a este polo es el amor, en tanto agapé o caridad, como fuente de inicio del perdón. Este amor no sólo es incondicional, sino que coloca a quien perdona en las alturas. De esta manera, se vuelve manifiesto el contraste que existe entre el lugar de quien perdona y la condicionalidad y la profundidad de quien ha cometido la falta. Aquí también se recurre a la tradición religiosa, en este caso, cristiana, para explicar la capacidad de perdonar lo imperdonable, es decir, aquello que por su aberración no se puede castigar. Mientras autores como Arendt ${ }^{29} \mathrm{o}$ Jankélévitch ${ }^{30}$ están en contra de dicha posibilidad, ${ }^{31}$ Ricœur la avala recurriendo a los planteos de San Pablo. Así explica que entre la fe, la esperanza y el amor, esta última virtud es "la más valiosa: porque el amor es la Altura, la grandeza misma. Pero si el amor disculpa todo, ese todo comprende lo imperdonable. Si no, el propio amor sería aniquilado."32

28 Es cierto que Ricœur no utiliza el término "atestación", pero sí "confianza", dóxicamente asociada a la atestación. Cf. Ricœur, Op. Cit., 628: "Para explicar este último acto de confianza, no existe otro recurso que asumir la última paradoja que ofrecen las religiones del Libro y que encuentro inscrita en la memoria abrahámica." El sentido de la atestación es la "convocación pro-vocante al ser-en-deuda" (Ricœur, Sí mismo como otro, 390).

29 Hannah Arendt, La condición humana.

30 Vladimir Jankélévitch, El Perdón.

${ }^{31}$ Cf. Ricœur, La memoria, la historia, el olvido, 599: “... sólo se puede perdonar allí donde se puede castigar; y se debe castigar allí donde hay infracción a las reglas comunes." Arendt, por su parte, afirma: "La alternativa del perdón, aunque en modo alguno lo opuesto, es el castigo, y ambos tienen en común que intentan finalizar algo que sin interferencia proseguiría inacabablemente." (Arendt, La condición humana, 260).

32 Ricœur, Op. Cit., 596-7. 
Habiendo sido descrito al perdón como una relación bipolar y asimétrica entre un culpable y una víctima, el siguiente paso consiste en determinar en qué dimensiones opera. Para ello, se toma como punto de partida la distinción de los cuatro tipos culpas de Jaspers (criminal, política, moral y metafísica). Al igual que Derrida, Ricœur dedica una parte importante de su exposición en deslindar el perdón de la dimensión jurídica. ${ }^{33}$ Esta confusión se funda en la tesis del carácter sustitutivo del castigo y el perdón, utilizado como premisa contra la posibilidad de perdonar aquello que no puede ser castigado. Aunque el castigo y el perdón se refieran al mismo acto criminal, uno no sustituye al otro, pues perdonar lo ya castigado crearía impunidad. De este modo, “... el perdón no puede enfrentarse frontalmente con la falta, sino marginalmente con el culpable." ${ }^{4}$ Una de las consecuencias más importantes de esta distinción entre el perdón y la justicia es la posibilidad de perdonar crímenes imprescriptibles. En el desarrollo de esta argumentación, Ricœur disocia al crimen del culpable, adelantando lo que será su explicación de cómo funciona el perdón: "son los crímenes los que se declaran imprescriptibles. Pero los castigados son los individuos. Teniendo en cuenta que culpable significa penable, la culpabilidad se remonta de los actos a sus autores." 35

El perdón tampoco opera de manera política. Arendt está en lo correcto al ubicarlo junto con las acciones humanas, no sucede lo mismo con la tesis de que "... descansa en experiencias que nadie puede realizar en la soledad y que se fundan totalmente en la presencia del otro." 36 Los fracasos que se produjeron al intentar institucionalizar al perdón demuestran que es inconcebible su carácter

33 Cf. Ricœur, Op. Cit., 586: "La cuestión planteada es, pues, la del perdón al margen de las instituciones responsables del castigo."

${ }^{34}$ Ricœur, Op. Cit., 599.

35 Ricour, Op. Cit., 605.

36 Ricœur, Op. Cit., 623. 
político. ${ }^{37}$ El motivo de esta imposibilidad radica en el amor sobre el que se funda. Apoyándose en Kodalle, ${ }^{38}$ Ricœur sostiene que los pueblos no son capaces de perdonar, por carecer de conciencia moral y porque, a escala colectiva, el amor y del odio funcionan de manera distinta que la memoria. ${ }^{39} \mathrm{De}$ este modo, el tratamiento de esta capacidad queda encuadrado en las dimensiones moral y metafísica. Esta última dimensión fue llevada a cabo en el análisis de la falta, donde ésta era vinculada con el mal y, por esa vía, con la soledad y el fracaso. Queda pendiente, pues, su dimensión moral.

El perdón es la capacidad de desligar al agente de su acto. De esta manera, queda presente la deuda del agente, pero sin la carga de culpabilidad. La falta no se olvida, pero una vez desvinculado de la carga, "el culpable [está] capacitado para comenzar de nuevo: ésta sería la figura de esta desligadura que rige todas las demás.”0 Con esta tesis, toma distancia respecto, por una parte, de Arendt, para quien el perdón consistiría en desligar el acto de sus consecuencias. ${ }^{41}$ Esta posición resulta contraproducente para Ricœur, ya que funcionaría de manera análoga a como lo hace la amnistía, es decir, imponiendo una suerte de olvido de la deuda con el pasado. ${ }^{42}$ Se trata, por el contrario, de levantar la condena al sujeto moral, sin

\footnotetext{
37 Cf. Ricœur, Op. Cit., 625.

38 Klaus Kodalle, Verzeihung nach Wendezeiten?

39 Cf. Ricour, Op. Cit., 608-9.

40 Ricœur, Op. Cit., 628.

${ }^{41}$ Cf. Arendt, Op. Cit., 260-1: "quizás el argumento más razonable de que perdonar y actuar estén tan estrechamente relacionados como destruir y hacer, deriva de ese aspecto del perdón en el que deshacer lo hecho parece mostrar el mismo carácter revelador que el acto mismo."

42 Cf. Ricœur, Op. Cit., 581: "Si ésta [amnistía] pudiese salir adelante finalmente - y, por desgracia, nada impide franquear la débil línea de demarcación entre amnistía y amnesia -, la memoria privada y colectiva sería desposeída de la saludable crisis de identidad, que permite la reapropiación lúcida del pasado y de su carga traumática. Más acá de esta prueba, la institución de la amnistía sólo puede responder a un deseo de terapia social de urgencia, bajo el signo de la utilidad, no de la verdad."
} 
dejar de condenar por ello el acto. Como adelantamos más arriba, Ricour también disiente con Hartmann y Badiou, quienes consideran imposible desligar al agente de su acto. Según estos autores, el sujeto se identifica con sus actos, por lo que al desvincularlo de sus actos, se convertiría en un sujeto diferente al que cometió el crimen. ${ }^{43}$ Ricœur reconoce la dificultad de esta objeción, pero sostiene que la verdadera disociación no se produce entre un primer sujeto que comete el daño y otro segundo que es el castigado, como arguye Badiou. Reivindicando la metafísica aristotélica del acto y la potencia por sobre la sustancialista, sostiene que el desacople se produce entre "...la efectuación y la capacidad que ésta actualiza." ${ }^{\prime 4}$ Así,

bajo el signo del perdón, el culpable sería tenido por culpable por otra cosa distinta de sus delitos y de sus faltas. Sería devuelto a su capacidad de obrar; y a su acción, a la de continuar. Es esta capacidad la que se proclamaría en los pequeños actos de consideración en los que reconocimos el incognito del perdón representado en la escena pública. Finalmente, es de esta capacidad restaurada de la que se apoderaría la promesa que proyecta la acción hacia el porvenir. La fórmula de esta palabra liberadora,

43 Cf. Badiou, Op. Cit., p. 27.7. Si bien es cierto que Ricœur le hace esta observación a Derrida, y no a Badiou, cuyo artículo es posterior a La memoria, la historia, el olvido, considero que esta respuesta es más aplicable a Badiou que a Derrida. Como adelantamos en la nota iii, el argumento derridiano no hace descansar el cambio del sujeto en quien perdona, como sí lo hacen el texto de Ricour y de Badiou ("me acerco, una vez más, al argumento de Derrida: separar al culpable de su acto, en otras palabras, perdonar al culpable sin dejar de condenar su acción, sería perdonar a un sujeto totalmente distinto del que cometió el acto." (Ricour, Op. Cit., 628). Derrida, por su parte, sostiene que la modificación se produce en el momento del arrepentimiento del culpable, es decir, previo a la intervención del perdón: "imaginemos que perdono con la condición de que el culpable se arrepienta, se enmiende, pida perdón y, por lo tanto, sea transformado por un nuevo compromiso, y que desde ese momento ya no sea en absoluto el mismo que aquel que si hizo culpable. En ese caso, ¿se puede todavía hablar de un perdón? Sería demasiado fácil, de los dos lados: se perdonaría a otro distinto del culpable mismo." (Derrida, Op. Cit., 18).

${ }^{44}$ Ricœur, op. cit., 628. 
abandona a la desnudez de su enunciación, sería: vales más que tus actos. ${ }^{45}$

\section{Sobre los beneficios del perdón y su alcance político}

Como hemos visto, el perdón ricœuriano consiste en una relación de intercambio asimétrica y no mercantil entre la víctima y su perpretador. Una de las consecuencias de esta caracterización es que el perdón produce otros beneficios. En la presente sección comenzaremos por mostrar que además de la finalidad individual, éste posee una finalidad política. El rechazo del perdón colectivo, empero, lleva a que éste sólo se logre indirectamente a través del perdón individual. En la siguiente sección, discutiremos algunos puntos que esta propuesta dejó de lado, tomando la historia argentina reciente como contraejemplo al Apartheid sudafricano utilizado por Ricœur.

A fin de evaluar los beneficios del perdón, nuestro autor parte de un caso de la historia reciente, más específicamente el Apartheid sudafricano. Su punto de partida fueron los resultados de la comisión "Verdad y Reconciliación”, la cual investigó las denuncias de las violaciones de los derechos humanos cometidos durante el período entre 1960 y 1994. También examinó diversas peticiones de perdón por parte de los perpetradores, siempre y cuando estos probasen la motivación política de sus crímenes. Entre los resultados se destacaron los beneficios recibidos por las víctimas. Así, se explica que “... el beneficio es innegable en términos indivisamente terapéuticos, morales y políticos. Familias que habían luchado durante años por saber, pudieron expresar su dolor, dar libre curso a su odio ante sus

45 Ricœur, op. cit., 632. 
ofensores y delante de los testigos." 46 Reconoce, en cambio, el pragmatismo de los perpetradores que recurrían a la confesión pública como una estratagema para obtener una amnistía judicial. Pese a este resultado fáctico desalentador, uno de los móviles de este epílogo tiene como presupuesto la capacidad del perdón para levantar las limitaciones en las potencialidades del perpetrador. ${ }^{47}$ Ricœur señala en más de una oportunidad este beneficio existenciario-existencial: "esta diferencia respecto al estatuto de criatura contiene en reserva la posibilidad de otra historia inaugurada continuamente por el acto de arrepentimiento y acompasada por todas las interrupciones de bondad y de inocencia en el transcurso de los tiempos." ${ }^{48}$

Pese a rechazar el vínculo directo entre perdón y política, nuestra hipótesis es que este tratamiento del perdón incluye un objetivo indirecto de corte político. Entre los elementos que avalarían nuestro planteo se encuentran: el modelo en el que se inspira su propuesta, el ejemplo fáctico utilizado, y la aspiración política del autor. El modelo en el que se inspira no sólo es político, sino que también es interpretado de este modo. La lectura hegeliana de la Antígona de Sófocles pone de manifiesto la irreconciabilidad de dos regímenes legales antitéticos representados en las figuras de Antígona y Creonte. Su propuesta es que, la única manera de haber salvado a ambos hermanos, hubiera sido renunciando a sus parcialidades y reconciliándose a través del perdón. En efecto, “... esta reconciliación descansa en una renuncia efectiva de cada bloque a su parcialidad y adquiere el valor de un perdón en el que cada uno es verdaderamente reconocido por el otro. $\mathrm{Y}$ es precisamente esta conciliación

\footnotetext{
46 Ricœur, op. cit., 618.

${ }^{47}$ Cf. Ricœur, Op. Cit., p. 585: "La cuestión ahora planteada trata de otro enigma distinto del de la representación presente de una cosa ausente marcada con el sello de lo anterior." Es doble: por una parte, el enigma de una falta que paralizaría el poder de obrar de este 'hombre capaz' que somos; y, como réplica, el de la eventual suspensión de esta incapacidad existencial designada por el término de perdón."

48 Ricœur, op. cit., 631.
} 
mediante la renuncia, este perdón por reconocimiento, lo que la tragedia - al menos la de Antígona - es incapaz de producir." ${ }^{49}$ Cuando Ricœur recupera estas consideraciones en Sí mismo como otro tiene como objetivo poner de manifiesto la importancia política y ética de la sabiduría práctica en situación.50

La elección del ejemplo fáctico para determinar los efectos sociales del perdón tampoco es casual. Habiendo recurrido a Osiel ${ }^{51}$ para evaluar la relación conflictiva entre el enfoque jurídico y el histórico, Ricœur estaba al tanto de lo sucedido en los tribunales de Nuremberg, Tokio, Argentina y Francia. Sin embargo, cuando tuvo que elegir un caso para estudiar, se inclinó por el sudafricano. No cabe duda que esa elección fue motivada por el espíritu conciliatorio de su comisión. Habiendo reconocido el objetivo político de la reconciliación de la comisión "Verdad y reconciliación",52 recurre a su lema para contraponerlo al caso alemán y japonés. 53

Esto nos lleva finalmente a la aspiración de una política conciliatoria por parte de nuestro autor. El último apartado de La memoria, la historia, el olvido, denominado "El perdón y el olvido", presenta

49 Ricœur, Sí mismo como otro, 268.

50 Cf. Ricœur, op. cit., 271. Luego de presentar lo trágico de la acción, ilustrado por la Antígona, el filósofo proporciona las razones por las que se vuelve al formalismo de la ética. Dentro de la segunda razón se especifica: "Al no ser nuestro problema añadir una filosofía política a la filosofía moral, sino determinar los rasgos nuevos de la ipseidad que corresponden a la práctica política, los conflictos que derivan de esta práctica han servido de telón de fondo para los conflictos engendrados por el formalismo mismo en el plano interpersonal entre la norma y la solicitud más singularizadora." (Ricœur, op. cit., 271. La cursiva es del original).

51 Mark Osiel, Mass Atrocity, Collective Memory and the Law.

52 Cf. Ricœur, La memoria, la historia, el olvido, 618: "Pero la reflexión fue llevada bastante lejos por los protagonistas y por múltiples testigos directos para poder hacer un balance provisional sobre los obstáculos encontrados y los límites inherentes a una operación que no tenía como objetivo el perdón sino la reconciliación en su dimensión explícitamente política, como la delimitó K. Jaspers con el nombre de la culpabilidad política."

53 Cf. Ricour, op. cit., 618: "Comprender y no vengar", tal era el lema, en contraste con la lógica punitiva de los grandes procesos criminales de Núremberg y de Tokio." 
un resumen de lo tratado en el epílogo desde una perspectiva institucional. Cuando presenta a las instituciones del olvido, Ricœur explica que se fundamentan en el hecho de que "la sociedad no puede estar eternamente encolerizada consigo misma." 54 Aunque presenta una serie de reparos frente a ellas, reconoce valor a la paz interna y el aporte pragmático que la amnistía hace en esa dirección: "aquí, el filósofo se guardará de condenar las sucesivas amnistías de las que la República francesa en particular ha hecho gran consumo, pero hará hincapié en su carácter simplemente utilitario y terapéutico." 55 Nuestro autor reconoce la importancia epistémica del dissensus social, pero no parece tener la misma consideración de él a nivel político y jurídico.

Si el beneficio colectivo del perdón es la reconciliación, ¿cómo se puede producir, cuando es imposible un perdón colectivo? En términos generales, nuestro autor buscaría establecer que la reconciliación social es el resultado del pasaje de la memoria individual impedida a la memoria feliz a través del perdón. En primer lugar, asocia al perdón con la reconciliación. Ricoeur, en Caminos del reconocimiento, plantea al perdón como una vía para llegar a la memoria feliz: "la relación que establecemos entre la memoria y la promesa hace eco, en un sentido, a la que Hannah Arendt plantea entre el perdón y la promesa, en la medida en que el perdón hace de la memoria inquieta una memoria apaciguada, una memoria feliz." 56 Por su parte, en La memoria, la historia, el olvido la memoria reconciliada es señalada como una de las figuras de la memoria feliz: "así se despliega la dialéctica del desatar-atar a lo largo de las líneas de la atribución del recuerdo a sujetos múltiples de memoria: memoria feliz, memoria apaciguada, memoria reconciliada, como

\footnotetext{
54 Ricœur, op. cit., 641.

55 Ricœur, op. cit., 641.

56 Ricœur, Caminos del Reconocimiento, 170.
} 
serían las figuras de la felicidad que nuestra memoria desea para nosotros mismos y para nuestros allegados." 57

El vínculo entre la reconciliación y los demás no es, empero, inmediato en La memoria, la historia, el olvido. La reconciliación es presentada inicialmente desde una perspectiva psicoanalítica y ligada al vínculo con el pasado: la per-laboración, como trabajo de rememoración, rompe con los procesos de repetición y permite que el paciente se reconcilie con el pasado reprimido. Ni bien el concepto es introducido, se lo asocia con el perdón con la siguiente advertencia: "Guardemos de momento este término de reconciliación, que volverá al primer plano en nuestras reflexiones posteriores sobre el perdón." 58 El vínculo más explícito entre el perdón, la reconciliación y los demás se realiza en el cierre del epílogo, tomando a la atribución como hilo conductor:

... el esbozo de la teoría de la atribución, bajo la triple figura de la atribución a sí, a los allegados y a los otros lejanos, merece retomarse desde el punto de vista de la dialéctica del atar y del desatar propuesta por la problemática del perdón. En cambio, al extenderse así a la esfera de la memoria, esta dialéctica termina por alejarse de la esfera específica de la culpabilidad, para adquirir la envergadura de la dialéctica de la reconciliación. 59

Una de las consecuencias indirectas de la asociación del psicoanálisis y el perdón a través de la reconciliación, es que nos permite tomar posición en un debate acerca de cuál es la relación que existe entre el cuerpo de La memoria, la historia, el olvido y su epílogo el perdón. Por una parte, se encuentra la posición de

\footnotetext{
57 Ricœur, La memoria, la bistoria, el olvido, 636.

58 Ricœur, op. cit., 98.

59 Ricœur, op. cit., 635.
} 
Abel, quien sostiene que el perdón es una cuestión menor dentro de La memoria, la historia, el olvido y ajena al desarrollo del resto de obra:

... quisiera afirmar una primera tesis, que su filosofía del tiempo, de la memoria, del reconocimiento y del olvido no está ciertamente destinada a servir de estribo a una moral del perdón - lo digo contra las lecturas que tenderían a sugerir que toda la estrategia del libro está hecha para conducir al perdón, obligando de cierto modo a encontrar en él el único resultado a las aporías de la memoria y del olvido. ${ }^{60}$

Las palabras de Ricœur, explicando por qué este tema fue recluido al epílogo, parecieran abalar esta posición. El filósofo explica que ambas partes difieren en contenido y metodología. El abordaje metodológico, denominado "escatológico", no se identifica con ninguno de los tres anteriores (la fenomenología de la memoria, la epistemología de la historia y hermenéutica de la condición histórica). Por su parte, la falta como paralizador del hombre capaz y el perdón como suspensión de esta incapacidad difieren de la temática del cuerpo de la obra que es la representación del pasado. ${ }^{61}$ Badiou, por el contrario, sostiene que la totalidad de la obra está supeditada al perdón:

este es el desafío que presenta este vasto y bello libro: establecer "objetivamente", "reservando la atribución", el examen de los regímenes de memoria y de las proposiciones de la historia, de manera de hacer que el sujeto entre al escenario sólo

60 Abel, op. cit.

61 Cf. Ricœur, op. cit., 585: "La cuestión ahora planteada trata de otro enigma distinto del de la representación presente de una cosa ausente marcada con el sello de lo anterior." 
en el momento crucial de la correlación entre olvido y perdón. Luego el sujeto, no importa cuán anónimo ha permanecido no tiene ninguna oportunidad de escapar a la sobre determinación cristiana. ${ }^{62}$

Nuestra posición es intermedia. En nuestra opinión, el perdón no es una temática tan marginal ni en la obra de Ricour, en general, ni en La memoria, la historia, el olvido, en particular. En tanto se encuentra enmarcado dentro de la problemática hegeliana del reconocimiento, es posible establecer un puente de continuidad desde el interludio al noveno estudio de Sí mismo como otro hasta Caminos del reconocimiento, pasando por este epílogo de La memoria, la historia, el olvido. En lo que refiere a esta última obra, por su parte, en la medida en que el perdón es colocado en un lugar clave para el logro de una memoria feliz, es imposible defender su carácter marginal. Pese a ello, tampoco consideramos que la totalidad de la obra tenga en el perdón su culminación. Su temática es la representación, no el pasaje de la memoria impedida a la memoria feliz. Y aún si este fuera el caso, el perdón no es presentado como la única estrategia reconciliatoria con lo reprimido, ni la memoria impedida es la única posibilidad de la memoria abusada.

\section{Los problemas fácticos del perdón}

El perdón bipolar ricœuriano posibilita la perlaboración de las víctimas de crímenes, levanta los límites a las capacidades de los culpables arrepentidos y, de manera mediata, logra la reconciliación nacional. Sin embargo, consideramos que este planteo resulta

62 Badiou, op. cit., 27.3. 
sesgado, y que el caso tomado, en lugar de los tratados por Osiel, incidieron fuertemente para avalar las conclusiones a las que se arriba nuestro autor. De haber tomado otros ejemplos, se hubiera puesto fácticamente de manifiesto los límites de esta propuesta, ya que beneficia al criminal en detrimento de la víctima. En esta sección quisiéramos poner de manifiesto estos aspectos que quedaron ocultos, tomando para ello lo sucedido con los juicios a los represores en la Argentina. ${ }^{63}$

Tras un golpe de estado en marzo de 1976, un gobierno de facto cívico militar, autodenominado "Proceso de Reorganización Nacional", se hizo cargo del país durante seis años. Según los datos de diversas organizaciones de derechos humanos, el gobierno asesinó a alrededor de treinta mil personas. ${ }^{64}$ En lugar de reconocer la responsabilidad por estas muertes sumarias, se desentendieron de ellas, caratulando su situación de "desaparecidos". Tras la caída de este régimen, el gobierno del Dr. Alfonsín (1983-1989) inició los juicios a las responsables de este genocidio. Ante el aumento exponencial de las prosecuciones y el surgimiento de dos revueltas

63 Cf. Vezzetti, Pasado y presente. Guerra, dictadura y sociedad en la Argentina; Nino, Juicio al mal absoluto; y Bevernage, History, Memory, and State-Sponsored Violence. Time and Justice. Sin discutir la validez del ejemplo tomado, cabe observar que las conclusiones de Ricœur acerca del alcance del perdón en Sudáfrica surgen sólo del libro de Sophie Pons Apartheid. L'aveu et le pardon del año 2000. Hay obras posteriores que relativizan estos resultados y observan que el gobierno sudafricano se ha desentendido del destino de las víctimas y sobrevivientes del Apartheid, por lo que, consiguientemente los únicos beneficiados fueron los perpetradores. Cf. por ejemplo, Bevernage, op. cit., 62-64.

${ }^{64}$ De hecho, no existe una posición compartida al respecto. El informe de la Comisión Nacional sobre la Desaparición de Personas (Conadep), “... estima en 8960 el número de personas que continúan en situación de desaparición forzosa...” (Conadep, 1984, conclusiones). La organización Madres de Plaza de Mayo, por su parte, sostiene que los desaparecidos son treinta mil. Lo mismo sostiene el titular del Servicio Paz y Justicia en América Latina (Serpaj) y Premio Nobel de la Paz, Adolfo Pérez Esquivel, quien afirma que "treinta mil muertos y desaparecidos son las consecuencias de la dictadura militar argentina, de su participación en el Plan Cóndor, la internacional del terror que se implantó en América latina, principalmente en el Cono Sur, con atentados en otros países, intercambio de prisioneros y secuestros." (Pérez Esquivel, 2006). 
militares, este gobierno decidió limitar el alcance de los juicios. ${ }^{65}$ Para hacerlo legisló dos leyes, en 1986, la ley de punto final, que imponía un límite de sesenta días tras su declaración para el inicio de procedimientos ulteriores, y en 1987, la ley de obediencia debida que excluía de la prosecución a todos los miembros de las fuerzas armadas que hubieran actuado bajo órdenes superiores. Ambas leyes fueron rechazadas vehementemente por las organizaciones de derechos humanos.

El gobierno subsiguiente, del Dr. Carlos Menem (1989-1999), privilegió la gobernabilidad por sobre las violaciones a los derechos humanos. Con ese fin en mente, propuso una reconciliación nacional, que incluía el perdón de cientos de militares juzgados así como de militantes de izquierda acusados de crímenes durante la década del setenta. En este período de inmunidad algunos militares confesaron públicamente las atrocidades realizadas durante los años de la por ellos denominada "guerra sucia". De ellas, se destacaron la del capitán retirado Scilingo, que afirmó haber participado en dos de los llamados "vuelos de la muerte" en los que se arrojaron treinta víctimas drogadas desde un avión de la armada hacia el mar; y la del entonces jefe de las fuerzas armadas, general Martín Balsa, reconociendo oficialmente el uso de metodologías ilegales durante esos años. En lugar de aceptar seguir estas tendencias conciliatorias y perdonar a los perpetradores de estas masacres, las distintas organizaciones de derechos humanos coincidieron en rechazarlas y reclamaron su anulación a través de distintos actos públicos. Al grito de "ni olvido ni perdón" exigían que se juzgaran a los responsables de estos crímenes de lesa humanidad. En el año 2001 el poder judicial declaró la inconstitucionalidad y nulidad de las leyes de amnistía, punto final y obediencia debida. A partir del año 2003, el gobierno del Dr. Kirchner tuvo políticas proactivas para proseguir

65 Cf. Nino, 2006,145 y ss. 
con estos procedimientos, llevándolos hasta sus últimas consecuencias. Gracias a este cambio de actitud por parte del gobierno, se pudo llevar a juicio no sólo a militares subordinados, sino también a empresarios civiles vinculados con el régimen.

Dada la reconocida importancia de la presión de las organizaciones de derechos humanos en este cambio de tendencia respecto a los juicios a los culpables, surge la pregunta de qué hubiera sucedido si, asintiendo con la propuesta gubernamental, estas organizaciones hubieran perdonado a quienes confesaron estos crímenes, en vez de rechazar toda medida conciliatoria. Evidentemente hubieran quedado indemnes todos aquellos que no fueron juzgados después de la ley de punto final. Dicho de otro modo, los criminales se hubieran visto más beneficiados por el perdón que sus víctimas. Ricœur rechaza la eliminación de la pena a raíz del perdón, considerándola un acto de impunidad, pero pasa por alto que la anulación de una prosecución a raíz del perdón también lo sería.

Hemos visto que, a diferencia de Ricour, Jaspers insinúa el carácter casi alternativo de la culpa criminal y la moral. En su opinión es muy improbable que los culpables criminales vayan a tener culpa moral, porque es improbable que se arrepientan. Los que se arrepienten y asumen la culpa moral, carecen de culpa criminal. ${ }^{66}$ Esto significa que, independientemente de su arrepentimiento, el grupo minoritario es juzgado y condenado; los segundos, que se vieron beneficiados en lo económico, laboral e incluso social, en cambio, no tendrán juicio ni condena. A falta de castigo para estas personas, el perdón terminaría legitimando los privilegios que obtuvieron durante los años de violencia, amparándose en su alianza con los criminales, en detrimento de sus víctimas. Al igual que en el caso

66 Cf. Jaspers, op. cit., 90: "Culpa criminal: sólo afecta a unos pocos, a mí no; no me incumbe para nada. 
anterior, los culpables morales que fueran perdonados terminarían siendo favorecidos por sobre las víctimas.

\section{Conclusión}

En estas páginas hemos presentado las pautas generales del perdón tal como fueron planteadas en La memoria, la historia, el olvido. Inspirándose en el modelo hegeliano, éste fue caracterizado como un intercambio en el que cada una de los momentos debía renunciar a su parcialidad con el objeto de conciliarse. Esta obra se enfoca en los crímenes de los estados a sus ciudadanos, por lo que no se trata de una oposición de dos regímenes legales contrarios, sino de faltas, crímenes injustificables, que tienen víctimas y perpetradores. Para adaptar el modelo hegeliano a estos casos, Ricœur incorporó los planteos de Mauss sobre el don, y enfatizó la asimetría entre la víctima y el culpable fundamentalmente por medio de consideraciones cristianas en torno a la confesión y la caridad.

Los crímenes ofrecen datos para la reflexión. Le hacen pensar. Por eso mismo, en estas páginas hemos recurrido a la historia reciente argentina para reflexionar acerca de esta propuesta y encontramos que, por más que pueda haber reconciliación social y que los culpables puedan volver a ejercer plenamente sus capacidades, todo ello se logra en detrimento de las víctimas. En efecto, desde una perspectiva contrafáctica, hemos señalado que, una vez que el gobierno de turno da lugar a la amnistía, el perdón de las víctimas posibilita la impunidad de los perpetradores, pues no existe ninguna instancia que la pueda volver a revocar. Sólo la presión ciudadana impulsa a que la justicia se enfrente con dichos crímenes y el perdón anula esta presión. Por su parte, el perdón de aquellos culpables secundarios, que no cometieron ellos mismos 
crímenes juzgables, pero que se han visto beneficiados por los criminales, legitima la posición privilegiada que lograron obtener a costa de las víctimas.

En su artículo "Sanción, rehabilitación, perdón", escrito seis años antes de La memoria, la historia, el olvido, la preocupación de Ricœur parecía más enfocada en la víctima. Así explicaba que, "el perdón es una suerte de cura de la memoria, el fin del duelo. Quitado el peso de la deuda, la memoria es libre para grandes proyectos. El perdón le da a la memoria un futuro.” ${ }^{67}$ ¿Cómo es posible que el perdón se centrara más en la víctima que en el criminal? Básicamente porque el perdón funcionaba de manera diferente que en la obra del dos mil. Pese a haber referencias a la economía del don y a la lógica de la superabundancia, los problemas de la víctima y el culpable se resolvían por caminos diferentes. En efecto, era la justicia, y no el perdón, la que rehabilitaba al culpable. ${ }^{68}$ La rehabilitación es “... finalmente la que restaura una capacidad humana fundamental, aquella del ciudadano como portador de derechos cívicos y legales." ${ }^{69}$

Independientemente de todos los recaudos que se tomen, resulta contraproducente todo modelo de perdón que intente resolver en un mismo proceso los problemas de la víctima y de su perpetrador. Coloca a ambos polos en un inaceptable mismo nivel: el de dos parcialidades que deben conciliarse.

67 Ricour, The Just, 145.

68 Cf. Abel, L'éthique du pardon chez Paul Ricœur: "Dans Le juste, ainsi, Ricœur travaille particulièrement la notion de réhabilitation dans un sens qui voisine avec le pardon entendu en ce sens là."

69 Ricœur, op. cit., 141. 


\section{Bibliografía}

Abel, Olivier. L'éthique du pardon chez Paul Ricour. 2012. http://olivierabel.fr/ ricoeur/1-ethique-du-pardon-chez-paul-ricoeur.php

Arendt, Hannah. La condición humana.Barcelona: Paidós, 1993.

Badiou, Alain. The Subject supposed to be a Christian: On Paul Ricœur's Memory, History, Forgetting. The Bible and Critical Theory 2 (3) (2006): 27.1-27.9.

Belvedresi, Rosa. Consideraciones acerca de la memoria, el olvido y el perdón a partir de los aportes de P. Ricœur. Revista Latinoamericana de Filosofía, v. 32, n. 2 (2006): 199-211.

Bevernage, Berber. History, Memory, and State-Sponsored Violence. Time and Justice. New York \& London: Routledge, 2012.

Conadep. Nunca más. Informe de la Comisión Nacional sobre la Desaparición de Personas. Buenos Aires: Eudeba, 1984.

Delpech, Beatriz. La doble adscripción de la memoria como supuesto para 'desatar'. Peri, v. 6, n. 2 (2014): 174-191.

Derrida, Jacques. El siglo y el perdón. Fe y saber. Buenos Aires: Ediciones de la Flor, 2003.

Dosse, François. Paul Ricour. Les sens d'une vie (1913-2005). Édition revue et augmentée. Paris: La Découverte, 2008.

Hartmann, Nicolai. Ética. Madrid: Encuentro, 2011.

Jankélévitch, Vladimir. El perdón. Barcelona : Seix Barral, 1999.

Jaspers, Karl. El problema de la culpa. Barcelona: Paidós, 1998.

Kodalle, Klaus. Verzeihung nach Wendezeiten? Erlangen y Jena: Palm und Enke, 1994.

Mauss, Marcel. Ensayo sobre el don. Forma y función del intercambio en las sociedades arcaicas. Buenos Aires: Katz, 2009.

Nabert, Jean. Ensayo sobre el mal. Madrid: Caparrós, 1998.

Nietzsche, Friedrich. Genealogía de la moral. Buenos Aires: Ed. Libertador, 2011.

Nino, Carlos. Juicio al mal absoluto. Buenos Aires: Ariel, 2006.

Osiel, Mark. Mass Atrocity, Collective Memory and the Law. New Brunswick: Transaction Publishers, 1997.

Pérez Esquivel, Adolfo, "A 30 años de resistencia por la memoria, verdad y justicia", Página 12, 2006, http://www.pagina12.com.ar/especiales/30anios/momentos_clave-adolfo_perez_esquivel.html.

Polivanoff, Sofía, "Historia, olvido y perdón. Nietzsche y Ricoeur: apertura de la memoria y olvido a la vida". Tábano, n 7 (2011): pp. 83-101.

Ricœur, Paul. Sí mismo como otro. México: Siglo XXI, 1996.

—. The Just. Chicago and London: The University of Chicago Press, 2000.

Caminos del reconocimiento. Tres estudios. México: Fondo de Cultura Económica, 2006. 
—. La memoria, la historia, el olvido. Buenos Aires: Fondo de Cultura Económica, 2008.

—. Pasado y presente. Guerra, dictadura y sociedad en la Argentina. Buenos Aires: Siglo XXI, 2002.

Financiación: Esteban Lythgoe es miembro de la Carrera de Investigador Científico del UADE - CONICET (Consejo Nacional de Investigaciones Científicas y Técnicas de la República Argentina). 
TEMPORALIDAD, ACONTECIMIENTO Y PODER

TEMPORALITY, EVENT AND POWER

Aníbal Fornari

Facultad de Filosofía 'Edith Stein' de la UC de Santa Fe/ CONICET, Argentina ${ }^{1}$

Resumen: El capítulo se pregunta, en un recorrido dialógico ricœuriano principalmente con San Agustín y Hannah Arendt, por la génesis de la autoconciencia del origen y del sentido alterativo del poder. Tal autoconciencia es portadora, a través de las experiencias de pasividad del yo carnal en cuanto Urfactum relacional, del correctivo crítico inmanente frente a la tendencia ilusoria de todo poder a cosificarse en la autoafirmación y a precipitarse en la inercia mítico-política. Para afirmar la verdad originaria del poder dicha pregunta apunta al tiempo, al que el poder pretende someter. Así, en el primer momento del recorrido se puntualiza la trascendencia relacional del yo a través de la articulación entre temporalidad y natalidad. El segundo momento muestra que toda experiencia de poder vive mientras es la repetición novedosa de su verdad según la

${ }^{1}$ Aníbal Fornari, Instituto de Filosofía de la Facultad de Filosofía 'Edith Stein' de la Universidad Católica de Santa Fe, Calle Echagüe 7151, CP. 3000 Santa Fe, Argentina. Mail: afornari@santafe-conicet.gov.ar 
formalidad de la natalidad. Esta formalidad requiere tematizar el contraste fundamental que sustenta la experiencia viva del tiempo, a nivel personal e histórico. Finalmente, a través de la racionalidad narrativa, que despliega aún más la dinámica estructural de la temporalidad, se aborda la dimensión del acontecimiento, que profundiza el contraste del tiempo y redescubre el sentido originario del poder en forma convergente con el sentido propiamente humano de la identidad como ipseidad. Este trayecto teórico pretende poner radicalmente en crisis superadora el uso político de la violencia, al rememorarse el bicentenario de la independencia hispanoamericana. Palabras-clave: acontecimiento; alteridad; identidad; pasividad; verdad.

Abstract: This paper investigates, through a dialogical exchange between the ricœurian perspective and St. Augustine / Hannah Arendt, the genesis of the self-consciousness of both the origin and meaning of power. Such self-consciousness bears, or so I will argue, through the passive experiences of the carnal self in its quality of relational Urfactum, the corrective immanent criticism of power, insofar as power tends to become reified in some sort of self-affirmation and to become mythical-political inertia. In order to unveil the originary truth of power this investigation looks at time, which power wants to subdue. Thus, in its first part, the paper pinpoints the relational transcendence of the self through the articulation between temporality and natality. In the second part, it shows that every experience of power lives while it is the innovative repetition of its truth, according to the formality of natality. This formality calls for an appreciation of the fundamental contrast that underpins the living experience of time, both at a personal and an historical level. Lastly, and resorting to nar- 
rative rationality - one which reveals even more the structural dynamics of temporality - the paper tackles the dimension of the event, which deepens the aforementioned contrast of time and rediscovers the originary meaning of power as converging towards the properly human meaning of identity as being ipseity. With this reflection, I aim at radically criticizing the political use of violence by recalling the bicentennial birthday of Hispano-American independence.

Keywords: alterity; event; identity; passivity; truth.

\section{Introducción}

La finalidad de este capítulo consiste en reconocer la positividad generativa de sentido de las experiencias de pasividad, señaladas por Ricœur (1913-2005) como fuentes indicativas de la inyunción ejercida sobre el horizonte de totalización de la conciencia y de la praxis humana por la trascendencia del acto de existir. Cuya presuposición y excedencia a toda síntesis conceptual precipitada es afirmada desde la meta-categoría de alteridad. El eje desde el que se procede para alcanzar ese objetivo es la consideración del contraste constitutivo de la temporalidad a partir del diálogo crítico que Paul Ricœur sostiene con el primer filósofo que hizo vibrar de modo directo y existencial el enigma conceptual del tiempo: Agustín de Hiponá (354-430).

El poder es en general concebido como capacidad de anticiparse al tiempo, de calcular, prever y determinar los tiempos para ganar de mano e imponer la propia figura a lo existente. Ricœur prolonga el diálogo con San Agustín a través de su lectura de Hannah Arendt (1906-1975), para abordar la paradoja fundamental sobre la constitución ontológica y el sentido auténticamente novedoso del poder capaz de generar historia en vez de frenar el tiempo. Esto 
es: capaz de convocar las subjetividades desde su experiencia existencial originaria y dejarlas reunir para potenciando sus respectivas identidades a través del libre convivir. Se trata del nacimiento del poder desde un positivo sin-poder, que es críticamente asumido cuando se reconoce que el dinamismo hacia la propia identidad sólo puede acontecer como ipseidad, como atravesamiento liberador de la mismidad por la alteridad, a través de los vectores o experiencias de pasividad. En ellas, más allá del horizonte intencional, se indica meta-categorialmente la discreta presencia de la alteridad fundamental, sugiriéndose desde

la pasividad de la carne en tanto mediadora entre sí-mismo y el mundo, asido en sus diversos grados de practicabilidad y, por tanto, de extrañeza; hacia el extranjero en cuanto es mi semejante que, sin embargo, permanece exterior a mi-mismo; finalmente, hacia ese otro que constituye el foro interior, figurado por la voz de la conciencia que se dirige a mí desde el fondo de mi-mismo. ${ }^{2}$

El otro habla en los intersticios de la experiencia de sí indicando el acontecimiento de un poder-ser que se origina y nutre desde la pasividad meta-política de la experiencia de sí. Íberoamérica necesita descubrir la experiencia originaria de lo político, superadora del estigma que concibe el mecánico prejuicio partidista, la prepotencia de la fuerza y el crimen de la violencia como parteros del poder capaz de instaurar el bien en la historia. Sin ponerse en cuestión a sí misma como un todo complejo, que ya contiene - aunque la oculta - la clave de la experiencia de sí como acontecimiento de un dramático encuentro, no desplegado aún en su positividad me-

2 Paul Ricœur, Réflexion faite. Autobiographie intellectuelle (Paris: Esprit, 1995), 105. [Mi traducción. De aquí en más, para todos los textos de Ricœur y de otros autores citados en francés, la traducción es mía]. 
todológica, aún cuando se han atestiguado en su historia potentes indicios pre y meta-políticos de una cultura del encuentro, de alta significación universal en el proceso mundial venidero. Mientras por el camino del estigma sólo se instala el injusto fracaso de las naciones y de su gente, concentrando la culpabilidad en los de afuera, sin pensar ni asumir la responsabilidad por una discusión libre y profunda sobre las condiciones efectivas de posibilidad del desarrollo de sus pueblos.

\section{1 - Temporalidad, historia y natalidad}

Lo que está en cuestión para Agustín no es que el tiempo sea algo que concierne al movimiento cósmico - como tan bien lo vio Aristóteles (384 a. C.-322 a. C.) -, sino la determinación astral del tiempo como factor último y decisivo. Para Agustín la cosmología se añade a la antropología porque ésta asume el proto-fenómeno por el que hay fenómenos. A partir del proto-fenómeno del yo-carnal, que en cada caso es uno mismo, el cosmos se le brinda en su atractivo y lo induce a la curiosidad impactando en su corazón: en esa relación originaria al infinito atestiguada por el deseo-de-ser. La emisión alterativa de sentido emanada de la presencia cósmica desbordante de todo contorno, pero donante de inteligibilidad desde su imponente y aparente regularidad, abre la pregunta por el tiempo y por su totalizante enigma. El yo, como autoconciencia del cosmos, realiza entonces ese nivel de la naturaleza por el que ella despierta al significado y se expone a la pregunta que introduce al mismo cosmos en la inquietante apertura desproporcional del ser relacional-personal.

Si bien Ricour advierte que "el fracaso mayor de la teoría agustiniana consiste en no haber logrado sustituir una concepción cosmológica del tiempo con una concepción psicológica, a pesar 
del irrecusable progreso que representa esta psicología respecto de toda cosmología del tiempo", ${ }^{3}$ cabe preguntarse si, efectivamente, conviene a nuestra experiencia humana postular la necesidad de una interpretación psicológica que erradique la pertinencia antropológica de la dimensión cosmológica del tiempo. El sorprendente dinamismo pluriforme de la naturaleza material-viviente compenetrada desde la síntesis de la subjetividad con la corporeidad humana, al par que marca, sitúa y solidariza nuestra existencia en el orden natural de la finitud y la mortalidad, también esa misma naturaleza cósmica nos provoca hacia la altura con su inagotable carga de inteligibilidad, a ocuparnos de ella como nuestra casa y a explorarla como nutriente, tornándose ámbito de infinitos hallazgos y referencia de todos nuestros encuentros.

Sin la dimensión cosmológica, además de nuestra alma poética, se vacía de referencias el tiempo calendario (desde la pasividad de la carne), el de la sucesión de las generaciones (desde la pasividad de nuestra pertenencia intersubjetiva) y el tiempo de la huella estética y ético-religiosa (rememorada en la voz de la conciencia). No se trata de una marginalidad pietista sino de exhibir los presupuestos últimos alterativos atestiguados por la razón crítica, acerca de un componente decisivo de la pluralidad cultural inherente a una democracia viva. Lo cual es ratificado tras haberse experimentado la censura cultural y política totalitaria, que aprisionó al conjunto social en el tráfico de la sospecha y en el adoctrinamiento positivista. En efecto, Václav Havel (1936-2011), discípulo del filósofo Jan Patocka y con él perseguido y excluido por el régimen, llega a ser el primer presidente democrático de la República Checa (1989-2003), y muestra la positiva significación axiológico-política del contraste que constituye la temporalidad misma, cuando es llevada al diálogo

3 P. Ricœur, Temps et récit III. Le temps raconté (Paris: Seuil, 1985), 19. 
con el lenguaje de la alteridad del ser, a través de la naturaleza como signo:

Para una buena sociabilidad humana y para que la vida histórica no se transforme en un infierno es preciso el respeto hacia lo que nos sobrepasa infinitamente y que yo llamaría el milagro del ser. El bien auténtico, la responsabilidad auténtica, la justicia auténtica, el verdadero significado de las cosas tienen raíces más profundas que el mundo de nuestros cálculos terrenos y provisorios; tal es el mensaje que se puede encontrar en el fondo de la auténtica religiosidad en cuanto tal. ${ }^{4}$

Parece evidente que la conciencia humana del tiempo se configura a través de una operatoria que pone en correspondencia el estatuto tridimensional de la experiencia fundamental de pasividad. Cabe notar que, cuando se amanece a la vida propiamente política tras haber sufrido la larga noche de la experiencia totalitaria, en una sociedad infestada durante décadas por el miedo y por la propaganda discursiva auto-referencial y mentirosa, que establecía la universal mediación ideológica entre el yo-carnal y la realidad perdida, se vuelve a descubrir lo decisivo de la relación significante con la naturaleza. La experiencia de la pasividad de la carne en su nexo con el cosmos, antes deformada por la explicación materialista crasamente positivista y por la ridiculización de toda lectura ontológica, es redescubierta como una fuente de liberación de las conciencias hacia su estatuto originario.

La tarea es obtener nuestros criterios del mundo natural sin preocuparnos de las burlas a las que seremos sometidos y

\footnotetext{
${ }^{4}$ Václav Havel, Il potere dei senza potere (Milano-Bologna: La Casa di Matriona-Itaca, 2013), 182. [de aquí en más, las citas de este libro son de mi traducción].
} 
reivindicar para ello ese significado decisivo que se niega; respetar con humildad de sabios los confines del mundo natural y el misterio presente detrás de esos criterios; reconocer que en el orden del ser hay algo que manifiestamente supera nuestra competencia; dirigirnos siempre de nuevo al horizonte absoluto del ser, horizonte que - basta con quererlo - nos permite descubrir y experimentar nuestro ser de modo siempre nuevo. ${ }^{5}$

Esta inclusión de la prolongación cósmica de la corporeidad humana en la experiencia temporal y en la sustentación de la misma libertad de conciencia frente al poder despótico remite al carácter intencional de la conciencia que reconoce e ilumina lo dado.

Ciertamente, para Agustín el tiempo vivo y decisivo es, ante todo, tiempo del alma. De un alma que no es subjetivista ni intimista sino ex-tendida y distendida. La distentio animi se realiza en la espera lanzada hacia lo que adviene pasando y recuperando lo que habiendo pasado otorga densidad a la experiencia de sí en el instante presente. Aquí es donde el yo está y es en la intensidad del deseo-de-ser que lo constituye como pregunta dirigida a sí-mismo en cuanto Otro. Lo indeleble del tiempo, lo que no pasa ni deja de ser en el instante fugitivo del yo es precisamente esa referencia hacia donde todo lo disperso se canaliza y que es dictada por el deseo-de-ser del que nadie escapa y a lo que todo responde. Tal es la relación originaria constitutiva del yo carnal como deseo-del-Otro, de sí-mismo en cuanto Otro. Esta demanda alterativa es sostenida por la intentio animi que polariza hacia la exterioridad del Otro la vivencia del tiempo. Aquí está agazapada la intención del alma (o del ánimo o del yo) capaz de dejarse sorprender por el acontecimiento de lo que sea capaz de corresponder a la estatura del deseo y sea una relación para siempre, capaz de durar y crecer envolviendo

\footnotetext{
5 V. Havel, Il potere dei senza potere, 159.
} 
todas las otras relaciones, sin ser corroída por el tiempo perdido. Estando a la altura del deseo y del sentido de la pregunta que soy para mí mismo: quaestio mibi factus sum.

Entonces, la distentio animi, la distención del yo es la dilatación de la conciencia encarnada que acompaña el curso intencional del yo-en-acción articulado entre el presente, el futuro y el pasado. La intentio animi hilvana las relaciones efectivas que establece el actuar en el tiempo. Por tal razón el movimiento cosmológico - que de todos modos implica el tempus animi - es medido numerando su movimiento, pero no puede totalizar el contraste de la temporalidad que comienza con la transposición del instante cualquiera de Aristóteles hacia la centralidad existencial del triple presente: del pasado en la memoria presente, del futuro en la espera presente y del presente en la atención y en la iniciativa que articula en el ahora futuro y pasado. El instante aristotélico, en cambio, es un corte efectuado por el animus sobre la continuidad numerable del movimiento en un momento cualquiera, ya que todo momento puede ser el instante presente. Mientras "que el presente agustiniano es todo instante designado por un locutor como el 'ahora' de su enunciado". ${ }^{6}$

Los instantes numerables como puntos en una línea son de por sí indiferentes, son de nadie. El descubrimiento filosófico del tiempo en términos existenciales por parte de Agustín significa que "no hay futuro ni pasado sino en relación a un presente, es decir, en relación a un instante cualificado por la enunciación del yo que lo designa. El pasado no es anterior y el futuro no es posterior sino respecto de un presente dotado de la relación de sui-referencia, atestada por el acto mismo de enunciación". ${ }^{7}$ La primacía del presente es la primacía del cogito corporal que, aconteciendo en el mundo, se hace

\footnotetext{
6 P. Ricœur, Temps et récit III, 19.

7 P. Ricœur, Temps et récit III, 30-31.
} 
presente en un aquí y abora tomando la palabra, o sea, abriendo la pregunta que él es acerca de su ser y su destino con los otros en el mundo, transformando el instante cualquiera en presente vivo. La certeza del yo-soy es inútil si no es el reverso de la dramática pregunta quién-soy-yo, dirigida a sí mismo como un otro, como ipse. La fragilidad del decisivo presente se ahonda o se esfuma en la nada del mero instante numérico si esta dimensión existencial del tiempo no se personaliza en relación a la totalidad del sentido y a la universalidad y alteridad de todos los hombres. En tal lógica acontece el momento axial del tiempo histórico articulado con el tiempo existencial del individuo.

La pertenencia generativa a la particularidad cultural de una historia es la primera hipótesis de sentido que se da a conocer y a verificar en su capacidad de amigarse con la razón y la libertad personal, responsable de sí y de todos. El tiempo histórico emerge del entrelazamiento de aquel preguntar personal comprometido con respecto a la pluralidad generativa a la que pertenece el individuo, con el horizonte abierto al género humano. Porque un significado para la existencia no es tal si no es intencionalmente totalizador y abierto a una comunicabilidad crítica universal. Un mero mandato político invasivo es incapaz de configurar y hacer perdurar el antes y después axial del tiempo histórico, decretando su significado. Este siempre surge desde abajo, desde el silencioso y paciente trabajo de las conciencias que someten el sentido escuchado a la experiencia vivida. El momento axial del tiempo histórico es fruto del reconocimiento intersubjetivo de un acontecimiento vivido como encuentro excepcional, cuya incidencia liberadora de la existencia como un todo se realiza a través de generaciones de testigos que transmiten tal acontecimiento con su vida cambiada, tal como ello fue atestiguado por los "padres fundadores". Por definición, esa instancia axial sólo permanece viva al repetirse en su novedad existencial en el presente, como acontecimiento. 
¿Cuál es la razón de este énfasis en el presente y la presencia? El presente dotado de sui-referencia implicada en el acto mismo de enunciación arraiga en la forma de ser de quien es el portador del preguntar. El preguntar es responder - y en tal sentido comenzar siendo precedido por el Otro en el mismo acto de preguntar como pedido de diálogo - a una presencia relacional constitutiva del yo y por eso tan familiar y deseada cuanto desconocida, otra e in-deducible. La sui-referencia es, entonces, al sí-mismo en cuanto Otro y por eso no es tautológica: es la relación originaria, misteriosa es decir: luminosa, que se actualiza. Es el presente de la pasividad deseosa e interrogativa (sufrida) del yo-en-acción que, desde esa pasividad, se inicia abriéndose al horizonte total de la relación (actuándose).

Vincular la suerte del presente a la de la iniciativa - dice Ricœur - es quitarle de inmediato al presente el prestigio de la presencia en el sentido casi óptico del término. ... El presente ya no es una categoría del ver sino del actuar y del sufrir. Un verbo lo expresa mejor que todos los sustantivos, la presencia inclusive: es el verbo "comenzar"; comenzar significa dar a las cosas un nuevo curso, a partir de una iniciativa que anuncia una secuencia y así abre una duración. Comenzar es comenzar a continuar: una obra debe proseguir. ${ }^{8}$

¿Quién comienza y toma la iniciativa? Alguien que es certeza-de-sí como obra creada que ya-es-ahí, la obra del yo-soy que debe proseguir. Sólo desde esa experiencia previa y a menudo silenciada es posible que emerja la experiencia del yo-puedo-responder asumiendo el conjunto de poderes y de no-poderes que me constituyen como cuerpo propio o como carne mediadora entre el curso

8 P. Ricœur, Temps et récit III, 332-333. 
del tiempo vivido y el curso del tiempo del mundo, desafiando de nuevo la dicotomía insostenible entre exterioridad cósmica e interioridad reflexiva.

¿Cuál es la condición ontológica de posibilidad de la temporalidad y de la sociabilidad que se manifiesta en el acontecimiento del "comenzar"? ¿Cómo es posible sustentar la capacidad de iniciar una acción incidente en el curso del mundo a través del consentimiento a vivir-juntos, renovado por el metódico y permanente intento de ejercer la amplitud correctiva de la capacidad de encuentro? Aquí Ricœur asume plenamente la genialidad filosófica de Agustín quien, desde el principio ontológico de creaturalidad de lo existente, discierne la diferencia entre el hombre (varón-mujer) y los animales en el hecho de que el hombre es, por su dimensión espiritual que atraviesa y trasciende la humanidad como especie, un existente único y singular (unum ac singulum), mientras que la vida animal emerge como pluralidad (plura simul iussit existere) y es inmanente a la especie. ${ }^{9}$ En efecto, hay iniciativa porque hay alguien que, en cuanto tal, es un inicio. Sólo un sujeto que es comienzo puede ejercer en el cosmos y en su mundo la acción de comenzar en el sentido fuerte de retomar y desplegar lo precedente de un modo dramáticamente nuevo a nivel del sentido sobre el modo de tratarse a sí-mismo, a los otros y a las cosas, desde la libertad. Un existente singular abierto a lo universal conlleva una distancia interna en la que enraíza la libertad. Todo ello resulta de la constitución relacional originaria de quien es único y singular y, por tanto, initium. ${ }^{10}$ Pues antes de que sea creado el hombre había principio, la naturaleza había comenzado y estaba en marcha, pero el inicio aún no existía.

\footnotetext{
9 Cfr. San Agustín, De civitate Dei, ed. bilingüe, trad. de José Morán (Madrid: BAC, 1964), tomo XVI de las Obras de San Agustín, Liber XII, cap. XXI.

10 "Para que haya inicio es creado el hombre, antes de quien no hubo inicio". "Initium ... ergo ut esset creatus est homo, ante quem nullus fuit". Agustín, De civitate Dei, tomo XVI, Liber XII, cap. XX. [mi traducción]
} 
Al ser en el mundo quien es inicio abre el mundo porque lo trasciende en una soberanía protectora que le da un destino. Proviniendo de la materialidad cósmica y de la novedad terrena de la vida en la diversidad de sus formas y especies, el yo corporal participa y excede el orden de la multiplicación de las especies. Dicha excedencia relacional y fundante constituye también al existente personal como aquel hacia y para-quien se ha ido efectuando el devenir cósmico-evolutivo, que encuentra en él su télos y que él mismo puede leer e ir reconociendo en su verdad inagotable, tal como cultivando lo donado y capitalizado por su propia historia en el horizonte de la intersubjetividad universal. Entonces, por un lado está lo que principia, hay principium: la expansión vertiginosa del cosmos, la configuración excepcional de la tierra, la irrupción de la vida. Por otro lado hay initium en el continuum del movimiento del universo. Dice H. Arendt comentando a Agustín:

Dios crea al hombre como una creatura temporal, homo temporalis; el tiempo y el hombre fueron creados juntos y esta temporalidad es confirmada por el hecho de que cada hombre debe su vida no sólo a la multiplicación de las especies, sino al nacimiento, a la entrada de una nueva criatura que aparecía como algo enteramente nuevo en medio del continuum del mundo. El propósito de la creación del hombre fue hacer posible un inicio. ${ }^{11}$

La reproducción es multiplicación de la especie mientras la procreación es única, es alumbrar y dejar-ser la singularidad imprevisible que acontece.

${ }^{11}$ Hannah Arendt, La vida del espíritu, trad. Ricardo Montoro y Fernando Vallespin (Madrid: Centro de Estudios Constitucionales, 1984), 496. 
Sólo quien es procreado viene al mundo bajo la formalidad del nacimiento: porque irrumpe la novedad de un deseo infinito e incolmable que se pone en juego en toda relación atrayente y creativa como demanda de verdad y felicidad. Tal es el sentido de que en el hecho de la natalidad enraíza ontológicamente la facultad de la acción humana. Así prosigue H. Arendt,

Dicho en otras palabras, el nacimiento de nuevos hombres y un nuevo comienzo es la acción que son capaces de emprender los humanos por el hecho de haber nacido. Sólo la plena experiencia de esta capacidad puede conferir a los asuntos humanos fe y esperanza, dos esenciales características de la existencia humana que la antigüedad griega ignoró por completo... ${ }^{12}$

¿Qué tienen que ver con la temporalidad estas dos esenciales características natalicias de la existencia? Precisamente que en ellas acontece la intensidad carnal de la alteridad fundamental del sentido que salva los deseos infinitos, sintetizando la temporalidad en el triple presente del yo-tú/Tú agustiniano: presente del presente, presente del futuro y presente del pasado. La fe es el reconocimiento de una tal presencia alterativa presente, en la que se vuelca una espera fundada, o sea, la esperanza como presente del futuro, radicada en una promesa cumplida, o sea, en el presente del pasado por la memoria confiada en quien se ha verificado que, sin ahorrarse ni ahorrar el drama de la existencia, no le falla al deseo-de-ser. En realidad es la experiencia viva de aquellas dos esenciales características natalicias de la existencia las que despiertan en la mente histórica este concepto radical de natalidad que finalmente las sustenta filosóficamente. Esta experiencia de la capacidad de

\footnotetext{
12 Hannah Arendt, La condición humana, trad. Ramón Gil Novales (Barcelona: Paidós, 1993), 266.
} 
novedad inherente a la radical pasividad del nacimiento es la que le otorga al obrar el anclaje ontológico e histórico, de modo que cada acción puede ser comprendida como el eco del comienzo de una vida ella misma prometida a comenzar. La temporalidad converge en el presente porque vivir es comenzar. Y comenzar es responder al origen, al acontecimiento de nacer. La superior racionalidad del homo temporalis consiste en cuidar la libertad responsable porque respondiente, renovando la autoconciencia del comienzo.

\section{2 - Poder y verdad}

Renacer, comenzar es, entonces, la tarea principal del bomo temporalis. Abrir y iniciar procesos de sentido y de vida buena es más propio de la temporalidad del hombre que la presunción de ocupar espacios y acumular dominios para quedar establecido en el tiempo, congelándolo. Esto no resulta de un esfuerzo voluntarista por renacer o de un arranque de irresponsabilidad que tira todo compromiso anterior por la borda. Sino que, ante todo viene la pasividad conscientemente vivida, que se torna fuente de la más alta actividad. Se trata del simple gesto de lealtad y de adhesión a la naturaleza del propio yo y, por ende, a la del tú y al milagro de existir, reconocido en cada despertar. Tal es el ejercicio de la iniciativa radicada en el inicio. Incluso como primer y fundamental gesto político que genera mutuo reconocimiento y, por ende, auténtico poder.

Iniciativa; he aquí la palabra clave a nivel fenómeno-antropológico - exclama Ricour comentando a Arendt; a lo que corresponde el consentimiento a vivir-juntos en el plano político. Por la iniciativa la acción se excluye de la labor y de la fabricación; por el consentimiento el poder se excluye de la dominación y de la instrumentación que, aplicados sobre el otro, es siempre 
violencia y sobre las cosas y la naturaleza, uso inteligente o usura irracional. Que la acción, además, pase por la palabra, no plantea problema, en la medida en que, en el plano político, el consentimiento vive de palabras intercambiadas o más precisamente, del principio mismo del intercambio de palabras, a saber, de la promesa. En última instancia se trata de actos de lenguaje que tejen los intercambios de donde nace el poder, si este ha de distinguirse de la instrumentación violenta. ${ }^{13}$

Tal es la grandeza y la fragilidad del poder, que no es lo mismo aunque conserve un aire de familia, que el reconocimiento de la autoridad personal en algún oficio o forma de vida. La especificidad propiamente política del poder responde a la aptitud de actuar en forma concertada, en virtud de una previa promesa o compromiso con una pre-estima generativa de la voluntad de vivir juntos en la diferencia de la pluralidad. Tal poder nunca es una propiedad individual sino que es una cualidad derivada de la condición humana de la pluralidad reunida por ese previo deseo de convivencia en la diferencia, sin la pretensión de constituirse en un todo homogéneo sino, llegado el momento, resistiéndose a ello. Pluralidad es lo contrario de la multitud desamparada y errática como ovejas sin pastor que, de alguna manera, es materia disponible a la aglomeración. La multitud es informe como una fuerza carente de finalidad propia y, por ende, como un instrumental apropiable por un déspota que le impone una forma partida de ser, para vivir-contra otro, doblegándose al espejismo de poder obtener todo.

La vigencia novedosa de Hannah Arendt consiste en haber sacado a la politología del estrecho marco de una teoría del estado para articularla con un factor ligado a la vida consciente de los individuos, evidenciando la responsabilidad del pensamiento en relación con

13 P. Ricœur, Lectures 1. Autour du politique (Paris: Seuil, 1991), 28-29. 
los acontecimientos históricos y políticos del mundo. Entendiendo el pensamiento no como una facultad abstracta, intelectualista y carente de profundidad, sino como la verdadera vida de la mente. Es decir, la capacidad que tiene cada hombre para buscar y captar un significado adecuado para vivir y para actuar, siguiendo la voz cuestionadora de la recta conciencia. Los totalitarismos del siglo XX nacen precisamente del hecho de inhibir sistemáticamente esta capacidad crítico-positiva del pensamiento humano. Hasta el punto de evidenciar como las formas más brutales, ideológicas y hasta científicamente calculadas de ejercer la violencia y la depredación se resuelven en la conciencia totalitaria, como lo destaca el título de uno de sus libros, en La banalidad del mal de 1963. Allí, más que identificar en Eichmann, como era de esperar, con el monopolio del mal absoluto, ella dirigió esta mirada despiadada pero de enorme realismo al hecho de que el mal mismo se esconde entre los pliegues de las decisiones ordinarias y profesionales de hombres normales, a los que el régimen ideológico militante hegemónico los ha privado, con su consentimiento, de la vida de la mente, del mismo sentido común.

Las decisiones de las que Eichmann trataba de defenderse eran justificadas por él por el hecho de que "sólo" estaba obedeciendo órdenes. El contexto político-partidista de total hegemonía donde él ejercía su oficio daba obviedad y licitud a comportamientos que, en una cotidianidad despierta y atenta al criterio de lo humano y lo inhumano, jamás consideraría moralmente factible. La cuestión sostenida por Hannah Arendt, en medio del griterío escandalizado y farisaico, es que el mal sigue siendo una posibilidad terrible pero abierta ante nuestra libertad y, por tanto, es algo que de manera realista todos podríamos hacer. Basta ver lo que hombres antes "normales" (varones y mujeres) son capaces de hacer cuando su actuar está cubierto y excusado por el contexto del odio, de la violencia y de la guerra. Ya Aristóteles nos advertía que una cosa es la lógica del poder político 
y otra cosa es el mecanismo violento de la fuerza despótica y que el pasaje de la una al otro es siempre posible, cuando la sociedad ha perdido las evidencias universales básicas de la dignidad humana y la unidad de sentido de las cuatro virtudes cardinales, al menos.

El auténtico poder político es, entonces, del orden del acontecimiento. Vive de la cultura del encuentro y de la continua reiteración gestual de la promesa de vivir juntos para bien-vivir. Un acontecimiento, en sí mismo potenciante de la confianza y de la esperanza también puede desvanecerse. Sobre todo cuando se enfatizan circunstancialmente las diferencias de ideas y los conflictos de intereses. Dicho poder desaparece tan pronto las diferencias de ideas y los conflictos de intereses, en lugar de convertirse en ocasión de una mayor autoconciencia y capacidad de juicio en la recreación de la voluntad de vivir juntos, degeneran en partidismo excluyente, en voluntad de soledad y de hegemonía despótica. ¿Qué subyace a esa regresión al imperio de la contraposición, del conflicto por el conflicto y de la violencia como horizonte de una presunta solución final? Subyace una desfiguración del sentido de la libertad propia de la singularidad y de la pluralidad humana que, en lugar de regirse críticamente por la sensibilidad a la verdad de sí y del otro, por la primacía de la exigencia de justicia y paz, de belleza y felicidad en la convivencia, hace prevalecer la ilusoria utopía voluntarista de hacerse a sí mismos, la estrecha autoafirmación solipsista y partidista de bastarse a sí mismo, donde crece el desierto de la despolitización, de la prepotencia, del irrespeto y de la enemistad social. En el miedo a la alteridad del otro se desvanece el sentido y el gusto por espacio público de aparición y relación, cuyo reconocimiento es consolidado por el sistema jurídico constitucional. Porque la libertad está siempre en inicio como capacidad de decisión y porque hay formas regresivas tentadoras siempre al asecho para deshacerse del problema, pacta sunt servanda y conservan la amistad, en este caso: el poder de intervenir de todos los implicados. 
¿Significa esto que la razonabilidad del poder político radica en última instancia en la forma jurídica y que se sustenta en la validez de las reglas pactadas? ¿Acaso una banda de ladrones y de mentirosos no se caracteriza también por sellar bien sus pactos, por cultivar cierto afecto que mantenga la complicidad y permita resolver cierto nivel de desavenencias, así como exigirse mutua sinceridad para estar atentos y evitar ser confundidos por las mentiras de otros o por tácticas que hagan fracasar sus fechorías? Esta forma de poder criminal ¿instituye espacio público de aparición y de relación? A no ser que esté hasta tal punto corrompida la vida política y desnaturalizada la sociedad civil, la mentira y la rapiña tratan siempre de operar a escondidas. Entonces ¿qué relación hay entre pluralidad, poder propiamente político de operar a la luz y verdad o pretensión de verdad? Para Arendt "una de las bases indispensables de todo poder es la opinión y no la verdad". ${ }^{14}$ Esto es importante y precisa ser bien entendido. En primer lugar, en la tradición filosófica, sobre todo en el realismo de Aristóteles, la praxis en general y la praxis política en particular procede sobre lo que es variable, "futuro y probable". Por tanto la doxa, la opinión co-recta según los griegos, es el logro de un conocimiento aproximado y sabio porque basado en la experiencia ampliada por la memoria de situaciones análogas y la pluralidad de opiniones. También es un conocimiento prudente, que se sabe ampliable y corregible porque la opinión es aquí lo contrario de la ilusión prepotente de saberlo todo, máxime sobre algo sólo probable que sucede en situaciones particulares y cambiantes.

En segundo lugar, observa Ricœur que "la doxa griega pasa a la Öffentlichkeit de la Ilustración, la cual pone en evidencia la diferencia de opiniones, sin la cual no existiría el problema del consenso para vivir juntos... ¿Se argumentaría en política si se dispusiera de

${ }^{14}$ H. Arendt, La crise de la culture (Paris: Gallimard, 1972), 29 [traducción y cursivas mías]. 
un saber intelectualmente constringente? Más aún: ¿no es acaso el error, a menudo el crimen, siempre la falta de los regímenes totalitarios pretender saber y saber por todos y en lugar de todos?". 15 En tercer lugar, al valorar la diferencia de opiniones como condición de un posible auténtico consenso y de algún modo invalidar la pregunta por la referencia del poder a la verdad, considerando con $\mathrm{H}$. Arendt que no es la verdad sino la opinión una de las bases indispensables de todo poder, se advierten dos cuestiones. La primera es que la diferencia de opiniones concerniente a la condición humana de pluralidad es una diferencia real y productiva cuando las opiniones son la expresión de una pluralidad singularizada y consistente. Esto es: cuando corresponde a un cierto grado de ejercicio crítico personal de la razón sensibilizada por la lealtad a la experiencia, apropiada e intercomunicada con el tino de objetividad propio del sentido común. ${ }^{16}$ Esta sensatez elemental impide que la propia capacidad mental de vinculación con lo real dado en la experiencia sea sistemáticamente mediada por los prejuicios y por las pre-comprensiones ideológicas que invalidan la intercomunicación productiva y sin mediatizaciones de las diversas opiniones.

Planteada esta primera cuestión se percibe que la opinión y, más aún, la diversidad de opiniones, como base del auténtico poder, implican una tensión de la opinión discursiva hacia la verdad buscada en el diálogo, cual versión más profunda y realista de entender el acceso a la verdad en base al primado de la propia conciencia, en la medida en que ella es educada en la sensibilidad por la simple objetividad de lo concreto dado en la experiencia e investida por el sentido de que el otro es, por principio, un bien para vivir más

15 P. Ricœur, Lectures 1, 33-34.

16 Cfr. Gerardo Galetto, Hannah Arendt: sentido común y verdad (Buenos Aires. Biblos, 2009). Es la disposición de apertura al mundo y a los otros de la mente humana que les posibilita revelarse en sus características elementales y que permite la comprensión y la comunicación intersubjetiva. 
humanamente la propia vida. En efecto, vuelvo al testimonio de quien como Václav Havel ha expuesto su vida por sostener paciente y pacíficamente el ideal de la verdad y de la libertad, cuando no había esperanza calculable alguna de que el sistema totalitario se resquebrajara, mientras su existencia encarcelada era cubierta por el manto del silencio impuesto por el estado despótico. ¿Qué es lo que hay que tener la valentía de aportar personalmente, desprivatizándolo, para que acontezca el espacio público de aparición y el auténtico poder político interpersonal? Se trata de fundar

nuestros comportamientos sobre la experiencia, sobre los criterios y sobre los imperativos que nos pertenecen y a los que garantizamos personalmente, como fruto de una reflexión sin preconceptos y sin censuras ideológicas: confiarse a la voz de la conciencia más que a las especulaciones abstractas; no inventarse una responsabilidad distinta de aquella que tal voz nos indica; no avergonzarse de ser capaz de amor, de amistad, de solidaridad, de compasión y de tolerancia sino, por el contrario, liberar esas dimensiones fundamentales de nuestra humanidad de su exilio en lo privado, y aceptarlos como los únicos auténticos puntos de origen de una comunidad humana dotada de sentido; dejarnos guiar por nuestra propia razón y servir en cada circunstancia a la verdad, como nuestra experiencia esencial. ${ }^{17}$

La segunda cuestión, que corona la indicación precedente, es que la prioridad política de la opinión está al servicio de una verdad más fundamental que la verdad declarada a nivel de ideas plasmadas en proposiciones y que esa verdad es el sustento esencial del poder. Se trata de una verdad originaria y a menudo olvidada, pero que es condición ontológica de posibilidad del intercambio dialógico

17 V. Havel, Il potere dei senza potere, 159. 
de opiniones: es la promesa de ver mejor contenida en el aporte posible de singularidades personales, consistentes e insustituibles, que no son apenas intercambiables átomos de multitud. Se trata de la verdad-viva que es la verdad-relación, la verdad del cuidado del espacio público de aparición, del gratuito entre-tenerse juntos, plurales y diversos para vivir-mejor. Sólo la intención de encuentro en esta verdad previa y viva abre el espacio público de aparición, mientras la mentira y las manipulaciones se preparan y cultivan en las tinieblas. Se trata, entonces, de la verdad en cuanto es "la visibilidad misma del vínculo social, del 'entre' del inter-esse". 18 Sobre esa base es después posible el debate de las ideas sin huir de la sensatez ni de la realidad del hecho político fundamental.

El consentimiento instaurador de vivir-juntos muestra que, si la fundación del poder viene de esa libre decisión de la pluralidad de preferir este camino y establecer las condiciones que lo facilitan antes que insistir en cobrarse los desencuentros o sacar ventajas injustificables, la reiteración de este origen puede ser favorecida pero no garantida por los mecanismos del sistema político-institucional. La organización, aún cuando sea evidentemente necesaria, es radicalmente insuficiente para cubrir lo que es del orden del acontecimiento, de lo que no existe sino en la medida en que reinicia en el presente. "Puesto que no hay consentimiento sin fundación, la fundación, paradojalmente, no es algo que hacer sino algo a repetir". ${ }^{19}$ Esto es: la fundación sólo es en cuanto acontece de nuevo. También reaviva la memoria y el deseo el reconocimiento de los hechos del pasado que dieron lugar al mencionado consentimiento, en cuanto también hoy son identificables al ser atestiguados y, así, ellos están ofreciendo la discreta promesa de un nuevo inicio posible.

18 P. Ricœur, Lectures 1, 33.

19 P. Ricœur, Lectures I, 41-42. 
Si el poder es volátil entonces la fundación es lo único que puede tornarlo duradero, pero, paradojalmente, la autoridad y durabilidad le son conferidas al poder por el consentimiento instaurador del vivir juntos, que puede reiniciar en el presente por obra y gracia de un acontecimiento de renovación relacional. El que no es posible producir, porque no es un artefacto, pero que sí es posible desearlo de modo explícito predisponiéndose a él, reconociéndolo en sus indicios y recibiéndole cuando adviene. Por eso se pregunta Ricœur: "¿Lo olvidado de lo político se escindiría siempre en dos: en lo olvidado de lo que somos por el solo hecho de vivir juntos -aunque sea de modo polémico-, y lo olvidado de lo que hemos sido en razón de una fundación anterior siempre presumida y tal vez nunca encontrable?" 20 Efectivamente, no se puede pretender un nivel epistémico de reflexión crítica dando por obvia la previa existencia de lo que somos, de lo que existe y bien podría no existir como lo atestigua su casual origen o dejar de existir como lo muestra su persistente inclinación al desvío y su decadente deterioro. El pasado tampoco es el fundamento mítico de la comunidad ideal a restaurar en términos románticos. El pasado ha sido tan dramático y pendiente de un acontecimiento como lo es el presente. Es parte del drama captar los indicios relacionales actuantes en el presente y reconocerlos como posibilidad de reabrir y ampliar el deseo de vivir-juntos. Porque para no hundirse en la repetición mecánica del estrechamiento del deseo en pretensiones sin horizonte, que anticipan el propio colapso como comunidad histórica, se requiere la decisión de secundar el deseo-de-ser y el mensaje estructural de la temporalidad misma. La vivencia de la historicidad brota de la autoconciencia distendida y alterativamente intencionada respecto del triple presente que articula la conciencia histórica, gracias al nexo vital del tiempo con su contraste.

20 P. Ricœur, Lectures 1,42. 
La distención, en cuanto vivida en la autoconciencia de la subjetividad encarnada, no se disipa en las contradicciones del futurismo utópico ni en el bloqueo ante lo nuevo del pasatismo ideológico, como maneras de huir del reclamo del tiempo. La consistencia articuladora del presente radica en la instancia de relación participativa del yo ante una presencia que trasciende el mero transcurrir y engloba el origen y el destino del tiempo, re-significándolos. Tal totalización del tiempo abierta a lo imprevisible e imprevisto desde el presente vivo que se nutre en la pulsión relacional infinita del yo, es correlativa a la experiencia de la historicidad en el ethos de una comunidad por eso mismo abierta e histórica, no encarcelada en el eterno retorno sobre su mismidad, ni agobiada por la horizontalidad del indefinido tiempo lineal progresista (a nivel instrumental pero no a nivel de la libertad). A través del presente del futuro vivido en la espera atenta de los sucesores que ingresan en el presente del pasado por la memoria afectivo-crítica de los predecesores, el yo como relación intencional a una presencia alterativa presente, que eleva la existencia y la mirada, es urgido por la posibilidad de protagonizar, asumiendo heridas arrastradas, una cultura del re-encuentro. Porque el tiempo mismo, en la distentio animi, es desafío al encuentro del contenido humano de los éxtasis temporales. En esta articulación interhumana entre contemporáneos desde predecesores para recibir a sucesores acontece el auténtico poder y la conciencia crítica de su sentido, de su operatividad y de su fragilidad.

\section{3 - El contraste fundamental de la existencia en la experiencia del tiempo}

¿En qué consiste para Agustín el contraste de la temporalidad para que la toma de conciencia de su estructura despierte la mirada a esa previa y olvidada positividad del entre, del inter-esse, que genera 
poder y no necesita tanto de nuestro hacer cuanto de nuestra capacidad de reconocer y proseguir la sugerencia de la alteridad en la pasividad? Señala Ricoeur que, desde la experiencia de sí como pregunta sufrida en la curiosidad deseosa de lo verdadero, Agustín plantea

de un solo lance el contraste de la eternidad y del tiempo. El trabajo de la inteligencia de ningún modo se concentra sobre la cuestión de saber si la eternidad es. La anterioridad de la eternidad respecto al tiempo - en un sentido de la anterioridad que resta por determinar - está dada por el contraste entre "el ser que no ha sido hecho y que sin embargo es y el ser que tiene un antes $y$ un después, que cambia y que varía. Este contraste es anunciado en Confess. XI, 6 como un grito: he aqui que el cielo y la tierra son; ellos proclaman que han sido hechos, pues cambian y varian". En tal sentido, pasa lo mismo con la eternidad que con el tiempo: que ella es no plantea problema; cómo ella es deja perplejo. De tal perplejidad procede la primera función de la aserción de la eternidad respecto del tiempo: la función de idea-límite. ${ }^{21}$

¿Es posible desentrañar algo de esta perplejidad penetrando en la función limitante de esta idea? La eternidad expresaría, por un lado, el modo de ser inescrutable de la alteridad fundamental que penetra en la auto-experiencia humana siendo atisbada por vía negativa, en un modo de receptar el contraste entre experiencia del tiempo y vislumbre de la eternidad en vista de superar de algún modo la precariedad temporal, produciendo en el tiempo la otredad respecto del tiempo. Porque cierto aspecto de la experiencia del tiempo declara nuestra desajustada finitud y la tensión del deseo-de-ser de llevar el tiempo a su plenitud mediante la realización de la específica aspiración humana sobre él: lograr la total simultaneidad, algo de la

21 P. Ricoeur, Temps et récit. Tome I (Paris: Seuil, 1983), 43. 
perfección concebida como ese tota simul con el que la eternidad ha sido definida, p. e. simultaneidad entre desear y obtener, entre proyectar y hacer, entre saber y poder, entre conocer y obrar, entre prometer y cumplir, entre mandar y obedecer, etc. Por otro lado, la eternidad como idea-límite, como alteridad que afirma su otro, en este caso la positiva significación del tiempo, indicaría en eso mismo la relativa trascendencia de la conciencia o del yo relacional, a la disgregación, el olvido y la pérdida inherentes al suceder. Éste, librado a sí mismo, apartado de la dinámica humana originaria, se tornaría en cierto modo despiadadamente destituyente y sustituyente de los individuos entre-sí.

La desproporción estructural vivida por el yo relacional que somos se enfrenta al desasimiento de su carnal ser en el mundo. La certeza de su mortalidad, de la que no sabe el día ni la hora de su cumplimiento, aflige la conciencia de sí y sus implicaciones alterativas y afectivas. Pero esa anticipada aflicción no sería posible sin su aún previa participación corporalmente temporalizada por el contraste con la dimensión espiritual de eternidad, que se experimenta en la trascendencia del yo respecto de la materialidad del mundo que él mismo despierta a la significación y a su expresión intersubjetiva en la sublimidad de sus obras, sobre todo aquellas que celebran el encuentro con el significado. Además, el mortal temor a la voracidad del tiempo es atravesado e intencionalmente recentrado en la síntesis que la distento animi de hecho realiza en el triple presente, cuando la idea-límite de eternidad se anticipa como condición trascendental de posibilidad del sentido del tiempo mismo como lugar de manifestación del significado. De modo que dicha idea-límite es tal porque no atrae hacia la anulación del tiempo en una especie de evaporación hacia la eternidad informe, sino que se encarna como vivencia de una experiencia de la relevancia eterna del tiempo que la prefigura. El límite que dicha idea señala es como si dijera: no se evadan del tiempo porque la eternidad necesita 
tiempo, necesita del drama de la desproporción o de la libertad en el tiempo. A la gélida pregunta ¿por qué hay tiempo y no más bien sólo ser? Responde la exclamación ¡qué bueno es que también haya tiempo, alteridad, pluralidad, diferencia e ipseidad y no sólo ser, eternidad, totalidad, unidad, indiferencia e identidad! La relevancia eterna del tiempo, es una esperanza fundada porque ya anticipada en el triple presente donde el yo ahí-está, articulando el tiempo y la eternidad en la densidad del instante. En la medida en que el instante es vivido en la autoconciencia de la infinitud relacional del yo respecto de la alteridad fundamental que, en su designio, resignifica, libera y rescata la pluralidad. De esta pasividad emerge el poder de los sin poder:

El único factor que puede tornar comprensible una verdadera esperanza es la profunda y sustancial certeza ... de que nuestra vida terrena no es apenas un suceso casual ... sino que es un componente integral ... del gran y misterioso orden del ser, en el que todo tiene su lugar insustituible ... y en el cual todo, de algún modo misterioso, se inscribe y es valorizado. Solo la dimensión de lo infinito y de lo eterno, acogido o inducido, puede explicar este fenómeno tan misterioso de la esperanza. ${ }^{22}$

Si la realidad con la que nos topamos en nuestra experiencia cambia y varía, entonces ha comenzado y ha sido hecha por quien es la fuente que no es hecha y de donde la realidad surge. El tiempo ya no es concebido como la apariencia de una movilidad cíclica sobre la base de una inmovilidad de fondo, sino como el lugar del acontecimiento de lo nuevo, imprevisible e imprevisto y, sin embargo, tan razonable para el sentido y la gozosa esperanza de la existencia humana. Como Ricœur lo señala en nota, citando a Jean Guitton

$22 \mathrm{~V}$. Havel, Il potere dei senza potere, 180. 
(1901-1999): "De la idea de creación resultan un cosmos temporario, una conversión temporal, una religión histórica. Así el tiempo es, al par, justificado y fundado". ${ }^{23}$ ¿En qué sentido el tiempo es justificado y fundado? Me parece que lo es en la medida en que tiempo y eternidad no se confunden en una perdurable monotonía (tiempo imagen móvil de la eternidad), ni se contraponen de modo dualista (tiempo sublunar de la generación y la corrupción, por un lado, y celeste eternidad astral que permanece indiferente e incólume a lo que pasa abajo, por el otro). Sólo la dualidad polar, el contraste y el requerimiento mutuo entre el tiempo y su otro irreductible, indicado por la idea-límite de la eternidad, hace saltar la chispa del significado del tiempo y de su pasiva posibilidad de ser atestado de donación.

Estamos ante una nueva figura del contraste entre mismidad e ipseidad. Lo otro del tiempo se indica en la experiencia de pasividad de la distentio animi. Por lo que señala Ricœur a partir de las Confessiones:

La pasividad acompaña con su sombra tres acciones, ahora expresadas por tres verbos: el espíritu espera (expectat), está atento (adtendit) y recuerda (meminit) ... El contraste se concentra en el presente. Por un lado, en tanto el presente pasa, se reduce a un punto (in puncto praeterit): es la expresión más extrema de la ausencia de extensión del presente. Pero en tanto él hace pasar [del futuro al pasado y del pasado al presente], mientras la atención encamina (pergat) hacia la ausencia lo que será presente, es preciso decir que la atención tiene una duración continua (perdurat attentio). ${ }^{24}$

Lo que perdura es la intentio praesens, el animus desiderans, la intencionalidad del yo o del alma deseosa que, a través del tiempo

23 P. Ricoeur, Temps et récit. Tome I, 43.

24 P. Ricoeur, Temps et récit. Tome I, 37. 
de los encuentros y de las cosas que pasan, en todo y por sobre todo busca, en la atención que perdura y en la que el yo se mantiene presente, el objeto o el otro correspondiente a la estatura significante de su deseo. ¿Quién es en realidad el sujeto de esa bisagra existencial de la desproporción en la que se contrasta creativamente el tiempo con su otro, de modo que el tiempo no es ya un desvanecimiento de la eternidad sino una participación en ella? No se trata de un sujeto que por ello se torna dueño del ser y del tiempo. Esta atención sostenida, esta tensión (intentio animi) que perdura, este yo-mismo polarizado hacia la idea-límite del tiempo, no es el dueño del significado de ese otro que, precisamente, se da como idea-límite cuyo contenido él no puede poner. No es dueño del tiempo porque no es dueño del objeto adecuado del deseo. ¿No es esto, acaso, hacer experiencia de la propia trascendencia alterativa dentro del límite de la propia mismidad, de modo que ya no se trata de una anónima eternidad sino de un rostro inalcanzable desde nuestro esfuerzo por existir?

En efecto, reflexiona Ricour sobre Agustín: "La noción de distentio animi no recibe lo que le es debido mientras no se contraste la pasividad de la impresión con la actividad de un espíritu tendido entre direcciones opuestas, entre la espera, la memoria y la atención. Sólo un espíritu tan diversamente tendido puede ser distendido". 25 Esto, por un lado, implica que la pasividad de la distentio animi como carencia de presencia plena de sí a sí-mismo y como carencia de eternidad no es apenas un límite de pensamiento (una idea-límite kantiana), sino también una ausencia sufrida en el corazón de la experiencia temporal. Una falta de ser, una limitación que se manifiesta en el sentimiento ontológico de la tristeza de lo negativo, de la distancia entre nuestro esfuerzo-para-existir respecto de la plenitud estable y siempre nueva de la vida gloriosa a la que el

25 P. Ricœur, Temps et récit. Tome I, 37. 
corazón aspira en el deseo-de-ser. Por otro lado y precisamente por esto último, la pasividad de la dialéctica entre intentio et distentio animi y el contraste significativo entre tiempo y eternidad ponen de manifiesto que la mencionada carencia es también positivo indicio de que ninguna respuesta a la mano, que sea más de lo mismo, está a la altura de satisfacer la grandeza destinal que urge desde dentro a la temporalidad humana.

El sentido del contraste entre tiempo y eternidad en San Agustín es dialógico más que dialéctico. A diferencia de la concepción unidimensional del tiempo como horizontalidad sinfín, que se afirma utópicamente contra la eternidad en un indefinido transcurrir que devora generaciones en su propia horizontalidad. Y dicho contraste también es dialéctico a diferencia de la interpretación dualista, donde la referencia vertical a la eternidad devalúa el significado del tiempo, cual precio a pagar para una liberación hacia lo eterno informe. El contraste de la eternidad, por el contrario, apremia el tiempo dándole una finalidad, al par que el tiempo se potencia a través de instancias que se suceden en la realización de la obra del hombre mismo y de su mundo, anticipando la eternidad que los lleva a la plenitud de su propia forma. El contraste nada tiene de evasivo como abandono de este mundo hacia otro mundo, porque el tiempo es dramática (o trágica) anticipación de otro mundo en este mundo. El contraste mediador de la eternidad relanza el tiempo colectivo de etnias y pueblos hacia el horizonte universal del tiempo histórico. En el mismo Agustín se verifica el dilatarse de la consideración del tiempo desde la ontología hermenéutica fundamental (Confessiones) hacia la filosofía de la historia (De civitate Dei).

Ricœur puntualiza lo precedente al señalar

tres incidencias mayores de la mediación de la eternidad en la especulación concerniente al tiempo. Su primera función es situar toda la especulación sobre el tiempo bajo el horizonte de una 
idea-limite que obliga a pensar conjuntamente el tiempo y el otro del tiempo. Su segunda función es intensificar la experiencia de la distentio en el plano existencial. Su tercera función consiste en llamar a esta experiencia misma a la superación en dirección de la eternidad y, entonces, a jerarquizarse interiormente, en contra de la fascinación por la representación de un tiempo rectilíneo. ${ }^{26}$

¿Cuál es la implicación decisiva de cada una de estas tres funciones? La primera consiste en que pensar de modo concreto y conjunto el tiempo que nos es familiar y el otro del tiempo que nos resulta enigmático, sin reducir uno de los términos y sin confundirlos, implica un acontecimiento que supera la idea-límite de la eternidad entendida como expresión de un corte epistemológico o como postulación de un genérico horizonte. A partir de un determinado momento irrumpe, en determinado espacio público de relaciones interpersonales y de conflictos de poder político-cultural, el encuentro con una personalidad excepcional. Tan conocida cuan sorprendente por la estatura inaudita de su inteligencia, por la novedad liberadora de sus juicios y de sus gestos, por su encendida pasión por los hombres, por la soberanía inerme y atrayente de su comportamiento. A tal punto que ayer como hoy es inevitable la pregunta: ¿pero quién es éste? ¿Por qué teniendo tanto poder y no lo usa para imponerse?

La segunda función consiste en intensificar la experiencia de la distentio animi en el plano histórico-existencial. No se puede vivir el tiempo sin calendario, cuyo proceso de constitución tiene múltiples y complejas implicaciones, la más importante de las cuales es la determinación del eje del tiempo. La distención de la conciencia en el triple presente privilegia un momento axial que ya no refiere a una instancia fundacional in illo tempore, cual pasado mítico de

26 P. Ricoeur, Temps et récit. Tome I, 42. 
una etnia que vive prendida al nostálgico recuerdo de su nacimiento, cada vez más recluido en lo inmemorial, donde el tiempo se confunde con lo eterno que retorna ritual y alegóricamente. Tampoco hace referencia a un futuro intrahistórico-utópico de cumplimiento lineal e indefinido y siempre postergado, cual modelo de perfección colectivo destinado a cosificarse y desvanecerse a medida que el presente cobra sus duras exigencias perentorias. En cambio, cuando el momento axial del tiempo es un acontecimiento que sucede en medio del tiempo, bisecando el tiempo, porque la alteridad de lo eterno se inserta y se reitera en él con rostro humano, entonces se abre una historia universal de la atracción sin fronteras a esa trama de encuentros humanos fundada en el cruce personalizado del tiempo con la eternidad. Donde la lógica de lo nuevo y del cruzamiento de lo diverso se da en anticipos testimoniales de una realización ecuménica.

La tercera función de la idea-límite es llamar a esta experiencia del triple presente a jerarquizarse interiormente. El pasado ya no es y el futuro todavía no es. Sólo el presente es y su mayor jerarquía consiste en que al cruzarse con la eternidad en la puntualidad del yo con-trae pasado y futuro en la conciencia distendida de la propia existencia desplegada en el tiempo. Abraza en la memoria-presente una historia en acción que viniendo del pasado actúa en el presente como contexto de pertenencia y de encarnación del yo. El cual es, a su vez, relanzado por la espera-presente hacia un futuro de posibles atisbados en el presente, cuya forma de cumplimiento no es del dominio del yo.

Atravesando estas tres funciones de la idea-límite de la eternidad Ricœur observaba que ellas cuestionan la fascinación por la representación de un tiempo rectilíneo, es decir, privo de referencia a la alteridad y de diálogo fundamental entre la temporalidad y su idea-límite. Lo que, en realidad, es banalización del conjunto del tiempo, descarte de lo que en él se arriesga y despersonalización 
del drama de la libertad en la historia. La representación del tiempo rectilíneo homologa la temporalidad reduciéndola a un proceso unidimensional de fuerzas colectivas cuyo progreso es instrumental. Esta interpretación es inducida por la impresión de un mundo de identidades privadas de horizonte humano, individualistas e impersonales, a-históricas y des-comprometidas y, por eso, irrelevantes. Lo que responde a una posibilidad degenerativa agazapada en la historicidad. Pero que debería ser pensada en contraste con la temporalidad originaria que entiende el hecho epocal sin justificar el poder que se vale de él como estrategia de ocultamiento y dominación. La competencia narrativa ipodrá contribuir, como expresión creativa de las variadas peripecias vividas por los hombres, a captar otros aspectos estructurales de la relación entre temporalidad y poder?

\section{4 - Ipseidad, acontecimiento y narración}

Hay un pasaje de Agustín que ha inspirado a Ricour respecto de la manifestación del tiempo en la narración, en cuanto éste hilvana cualquier acción en un horizonte progresivo de totalización, capaz de atraer al lector con la impronta poética del relato que se intercala en analogías y proyecciones imaginativas con su propia experiencia de vida. Agustín recuerda un canto de su amigo Ambrosio y dice: "Lo que se produce en un canto entero se produce también en una acción más amplia (in actione longiore) de la que el canto no es más que una pequeña parte; tal cosa se produce en la vida entera del hombre, cuyas partes son todas las acciones del hombre; esto se produce también en la serie entera de los siglos vividos por los hijos de los hombres". ${ }^{27}$ La amplitud de consecuencias significativas contenida en esta frase es así comentada por Ricœur: "Todo el imperio

27 S. Agustín, Confessiones, 28, 38. 
de lo narrativo es virtualmente desplegado aquí: comenzando por el simple poema, pasando por la historia de una vida entera, hasta la historia universal. A estas extrapolaciones, simplemente sugeridas por Agustín, se consagra esta obra". ${ }^{28}$

Si cabe decir que una vida no examinada es una vida que no merece ser vivida, también se puede decir que la primera figura de una vida examinada es una vida narrada. Esta conjunción de la vida en tanto humana con la narración y la temporalidad de la trama, manifiesta la racionalidad de la práctica narrativa y su despliegue de un aspecto decisivo de la dinámica estructural del tiempo, que es la dimensión del acontecimiento y que tiene especial relevancia para entender el origen y el sentido del poder. Lo cual debe ser interceptado y reconocido dentro de la dramática de la ipseidad - de sí mismo en cuanto otro - y liberado de su encierro en la tautología de lo mismo. La tensión narrativa entre concordancia y discordancia subsiste si comporta sorpresas y si éstas, al quebrar la coherencia previsible del relato, sin embargo son creíbles sin dejar de ser intrigantes. Esto invita a proseguir el hilo de la trama hacia lo que todavía está ausente y no obstante atrae a continuar el relato para culminarlo en una historia de pronto entendible como un todo que invita a pensar. La concordancia de un relato expresa el principio de orden, propio de la intentio animi, en la concatenación de los hechos narrados. Mientras la discordancia remite a la distentio animi como efectivo transcurso temporal sorprendido por encuentros imprevistos y por cambios de suerte que hacen de la trama una intriga.

Entonces, la lógica temporal del relato nunca es lineal y es racional justo por incluir lo imprevisible mediante una transformación reglada, que da lugar a la expectativa propia del relato significativo.

${ }^{28}$ P. Ricœur, Temps et récit I., 41. De tal sugerencia de Agustín fluye la respuesta de Ricœur con la extraordinaria trilogía Tiempo y narración. 
La racionalidad narrativa es coherente con la desproporción humana y revela al tiempo como sintesis de lo heterogéneo, de lo mismo y de lo otro, de la interioridad y la exterioridad, de lo previsible y de lo imprevisto. La concordancia discordante del relato es correlativa a la trascendencia encarnada del ego en el tiempo y, a través de esta característica, el relato manifiesta la racionalidad del contraste dramático del tiempo en su idea-límite. De hecho, el relato pretende sostener el testimonio de la vida más allá de su carnal caducidad. Pero el tiempo - y el curso del relato - están urgidos no tanto porque se deslizan hacia un previsto aunque incierto momento final donde la trama se apaga porque se le termina el tiempo, sino porque la alteridad de la idea-límite respecto del tiempo suscita la espera que dinamiza al relato. Además, esta finitud de la vida y de la trama exalta la búsqueda y la espera porque el triple presente expresa la relación originaria del yo a una presencia alterativa abscondita que se hace llamativa a través de las circunstancias. Esa presencia-ausente es el lugar fontal de la discordancia, cuestionadora del tiempo lineal. La discordancia hace posible la creatividad de la vida y de la competencia narrativa, restableciendo la concordancia con el nivel más profundo de la experiencia originaria del contraste del tiempo y del sí-mismo a través de otro. Como llanamente se dice, no hay auténtico relato sin misterio que deja pensando.

Es preciso reconocer que gracias a la desproporción humana acontece la conciencia de finitud y del desgarro por la contradicción enrostrada al deseo-de-ser por la persistencia del mal y la implacabilidad de la muerte. No hay relato significativo que no esté atravesado por esta contradicción. ¿Puede tener ello, acaso, un sentido convergente con el deseo que concentra al infinito el dinamismo de la vida y con ello nutre la trama de los relatos y la misma competencia narrativa? La contradicción que nuestra desproporción atesta ¿no significa, más bien, que estamos hechos para vivir la relación originaria con lo que nos supera para superar al fin la contradicción? Que el hombre 
supera infinitamente al hombre - de pascaliana memoria - significa que el deseo supera el poder de corresponderlo adecuadamente. No sólo habla de ello la inteligencia de las evidencias de nuestra desproporción abierta a la alteridad fundamental, sino también, a contrario sensu, la voluntad de abolirla mediante la exacerbación de la autoafirmación y la caída en la necesidad de re-mitificar el poder. De ahí la razonabilidad profunda de estas preguntas, que cuestionan la pretensión de liberar la vida desde la exacerbación vitalista de la vida misma o desde la capitulación a la sola finitud, encerrando al deseo en la lógica del idem:

si sabemos que debemos morir y que entonces todo es inútil ¿por qué entonces vivimos y por qué nos damos tanto por hacer? Y no sólo: ¿por qué casi todas las cosas esenciales a las que aspiramos o a partir de las cuales nos damos un sentido a la vida exceden evidentemente el horizonte del vivir? ... La esperanza en el sentido radical y profundo, ... en su esencia supera nuestra muerte y parece incomprensible y absurdo si ello es confrontado con nuestra conciencia de la muerte. No podemos creer que nuestra vida tiene un sentido y guarda una esperanza como condición constante del espíritu, si tenemos la certeza de que, con nuestra muerte, todo terminará definitivamente. ${ }^{29}$

¿Basta, desde un punto de vista ontológico, esta "natural fe y esperanza como condición constante del espíritu", para abrir la vida hacia la posibilidad de una certeza crítica, sin cosificarla en relaciones idolátricas frustrantes y violentas? ¿Qué dimensión de la existencia es preciso reconocer para que lo fundamental no sea petrificado? ¿Es suficiente la dimensión de la alteridad ética frente a la persistencia del mal y la contradicción de la muerte? ¿Cómo puede

29 V. Havel, Il potere dei senza potere, 179. (Cursivas mías) 
instruir en esto la trascendental competencia narrativa? La narración replica metódicamente esta problemática de la apertura de la existencia en la experiencia del tiempo a través de la función esencial de la dimensión del acontecimiento, que es el corazón del tiempo. Su estatuto ontológico alterativo "transporta a su más alto nivel la dialéctica de la mismidad y la ipseidad, implícitamente contenida en la noción de identidad narrativa". ${ }^{30}$ Pues en todo relato, la búsqueda de algo otro es lo que "hace posible la trama, la disposición de los acontecimientos que pueden ser considerados conjuntamente. La búsqueda es el motor de la historia en tanto separa y reúne lo que falta y su superación. Ella es el nudo del proceso. Sin ella no sucedería nada". ${ }^{31}$ La tensión de la búsqueda posibilita la atención de la espera. Ambos componentes de la racionalidad narrativa convergen en la dimensión del acontecimiento, que es el núcleo de sentido de la temporalidad y del relato que la expresa en sus concretas vicisitudes. Al respecto, Ricœur señala que

la diferencia esencial que distingue al modelo narrativo respecto de todo otro modelo de conexión reside en su estatuto de acontecimiento ... Mientras en un modelo de tipo causal acontecimiento y ocurrencia son indiscernibles, el acontecimiento narrativo, en cambio, es definido por su relación con la operación de configuración; el acontecimiento participa de la estructura inestable de la concordancia discordante que es característica de la trama; él es fuente de discordancia en tanto irrumpe y fuente de concordancia en tanto hace avanzar la historia. ${ }^{32}$

\footnotetext{
30 P. Ricœur, Soi-même comme un autre (Paris: Seuil, 1990), 167.

31 P. Ricœur, Historia y narratividad (Buenos Aires: Paidós, 1999), 127.

32 P. Ricœur, Soi-même, 169.
} 
El acontecimiento, entonces, sólo es y permanece como tal si asume lo humano e incide en la totalidad de la experiencia de sí, articulando los tres vectores de la experiencia de pasividad (la carne, la intersubjetividad y la conciencia), que remiten a la alteridad fundamental meta-categorial, y si, además, re-acontece en el presente abriendo un proceso en el que se renueva y relanza la novedad del sentido de la trama de la existencia. Si tanto la vida como la trama se configuran como síntesis abierta de lo heterogéneo, cada circunstancia como fragmento de tal heterogeneidad recibe su significado y valor del acontecimiento que va piloteando el proceso de totalización narrativa. Más aún, el mismo detalle circunstancial es portador de una vibración del acontecimiento princeps y esta vibración no sucedería sin tal detalle aportado por la circunstancia, que viene en todo momento elevada a la significación como lugar privilegiado de lo imprevisto. El sentido acontece en circunstancias, las totaliza en su conjunto a medida que ellas se suceden en la tensión discordante de un proceso unitario; finalmente, el acontecimiento revive en sí mismo desde el desafío de circunstancias que, solicitándolo de nuevo, lo actualizan, poniendo a prueba su consistencia para llevar a su culminación la existencia y el relato.

La racionalidad narrativa reúne poéticamente lo que en la cotidianidad se tiende a disociar: la sorpresa del sentido totalizador del rumbo de la trama y la particular dispersión circunstancial. ¿Qué es lo que cualifica un acontecimiento como princeps ofundante de un nuevo inicio? Precisamente su capacidad de convertirse en nuevo principio de inteligencia de lo real y de acción comunicativa a partir de las circunstancias, de lo particular, porque así atestigua una novedad que, en su libre accesibilidad, refiere y acompaña hacia el destino, despertando al uso integral de la razón. Estimo que es esto mismo lo que Ricour expresa de otro modo: un tal acontecimiento "pone en falta las esperas creadas por el curso anterior de los acontecimientos. Es simplemente lo inesperado, lo sorprendente y no se 
vuelve parte de la historia sino de contragolpe, una vez transfigurado por la necesidad en cierto sentido retroactiva, que procede de la totalidad temporal llevada a término". ${ }^{33}$ De contragolpe, lo inesperado se torna necesario para la inteligibilidad significativa de la totalidad de la vida como trama dramática de la libertad.

Señalaba antes Hannah Arendt que la irrupción de lo imprevisible e inesperado desde la idea-límite del tiempo genera, en quienes se topan con él, esa fe y esa esperanza fundadas, que transfiguran la naturaleza en historia. Esto es, en expectantes re-inicios de encuentros y descubrimientos que se anteponen a esa natural pendiente al retorno cíclico de lo mismo, en la multiplicidad de las dispersas vicisitudes humanas, reducibles al "nada nuevo bajo el sol". El acontecimiento fundante es portador de su propio contragolpe, que Ricœur denomina "inversión del efecto de contingencia en efecto de necesidad en el corazón del mismo acontecimiento". ${ }^{4}$ Pues éste no es tan sólo "lo que sobreviene en cierto modo antes de ser posible; sino que aporta también consigo su propio horizonte de inteligibilidad". ${ }^{35}$ Es decir, la experiencia de la correspondencia entre el deseo-de-ser y la excepcionalidad del contenido radical del acontecimiento, en cuanto significa la relación originaria constituyente del yo.

Este proceso de asimilación de su mensaje revelador, al par de consolidar el acontecimiento fundante en la conciencia crítica y sistemática de la experiencia de la vida personal e intersubjetiva, también puede desvirtuarse en un proceso de desligamiento de las consecuencias axiológicas del acontecimiento respecto de la gratuidad inmanejable de su originario acontecer. Así, comienza a

\footnotetext{
33 P. Ricœur, Soi-même, 170.

34 P. Ricœur, Soi-même, 170.

35 Claude Romano, L'aventure temporelle. Trois essais pour introduire à l'berméneutique événementiale (Paris: PUF, 2010), 32.
} 
erosionarse y a decaer en su integral significación existencial y a transmitirse en el tiempo mediante retazos semántico-culturales o ramales truncos a la moda de lo que sería una tradicionalidad íntegra y viva. Entonces, el acontecimiento ya no es reconocido como tal sino fagocitado como un hecho que tarde o temprano habría de suceder, según la lógica progresiva del determinismo histórico ontológicamente lineal. Tal sería la lógica de la decadencia de una gran civilización que, al concebirse en estado de ruptura y des-compromiso con la gratuidad del acontecimiento originario que la posibilitó en su poder-ser comunidad histórica, pierde también la inteligibilidad de las consecuencias que pretendía aislar, preservar y manejar a través de una concepción técnica del poder como capacidad de dividir la sociabilidad y producir hegemonía.

Mientras tanto, "más real que toda realidad, más exterior que toda exterioridad, el acontecimiento es lo que impide todo cierre de la existencia sobre ella misma, sobre sus posibles y sobre su sentido. Si de cualquier modo se quiere mantener el término, tal es, posiblemente, el verdadero 'realismo". ${ }^{36}$ Se trata del realismo que reconoce la existencia como aventura que excede las medidas del poder-ser proyectante porque recupera, junto a la experiencia de pasividad, el estado de nacimiento y de donación por el que esa existencia está "suspendida originariamente de posibles que ella no ha hecho posibles, inmersa en un sentido que la precede y que ella no sabría enteramente dilucidar, atravesada por una historia de la que ella no es el origen; en breve, como determinada en su esencia por acontecimientos fundadores" ${ }^{37}$ ¿Cuál es la estatura de esos acontecimientos fundadores de la experiencia del significado y del valor de la existencia? Ellos no son un depósito manejable de

36 C. Romano, L'aventure temporelle, 42.

37 C. Romano, L'aventure temporelle, 26. 
poderes porque originariamente emergen de la conciencia de las experiencias fundamentales de pasividad portadoras de

la íntima certeza de que el ser humano no es el dueño de existir en el modo del sí-mismo; sino que tal certeza le adviene a la manera de un don, de una gracia, de la que el sí-mismo no dispone ... La extrañeza de la voz [se refiere aquí Ricour a la voz de la conciencia moral, lugar privilegiado de la atestación de la alteridad] no es menor que la de la carne y la de el-otro. ${ }^{38}$

Esta extrañeza de las experiencias de pasividad es la misma extrañeza respecto de la racionalidad de la idea-límite de la eternidad, que exalta la relevancia decisiva de la temporalidad. Se requiere "lo otro del tiempo para hacerle plena justicia a la temporalidad humana; y esto no es para abolirla sino para profundizarla, jerarquizarla, desplegarla según niveles de temporalización cada vez menos 'distendidos y siempre más 'tendidos', non secundum distentionem sed secundum intentionem". ${ }^{39} \mathrm{El}$ tiempo de los mortales nos hiere porque es el contragolpe de la promesa estructural contenida en la vida como espera enclavada en el deseo-de-ser, aunque no seamos los garantes del cumplimiento de esa promesa. Tal como por el don del nacimiento nos tornamos responsables - respondientes - pero no dueños de nuestro existir: la donación está en nuestro origen y, por tanto, también en nuestra finalización. Origen y fin están articulados por la espera (y desde tal supuesto es posible también desesperar) porque somos ontológicamente promesa. A esta cuestión el poeta Leopardi responde con esta pregunta exclamante: "Qué grande es el pensamiento de que verdaderamente nada se nos debe. ¿Acaso alguien nos ha prometido algo? Y, entonces, ¿por qué lo

38 P. Ricœur, Réflexion faite, 108. [entre corchetes es mío]

$39 \mathrm{P}$. Ricœur, Temps et récit 1, 53. 
esperamos?". ${ }^{40}$ La mentada desproporción humana, ${ }^{41}$ que se decanta como conciencia del presupuesto de todos los presupuestos, esto es, como juicio expresivo del asombro por la existencia, se sigue diciendo de diversas maneras:

Nuestra existencia ¿no es acaso ella misma espera? ¿Dónde está la fuente primordial de la espera? Quiero decir que se trata de algo más profundo que una inclinación o que una disposición optimista de la mente humana determinada por la genética, la biología, la química o el medio cultural ... De alguna parte, detrás de todo eso, consciente o inconsciente, articulada de múltiples maneras pero siempre más profunda, está la experiencia humana del propio existir y de la existencia del mundo. ${ }^{42}$

La caída en la obviedad del existir se desliza en la censura al estatuto ontológico de la desproporción interna al hombre entre finitud e infinitud, cuya síntesis atisbamos en los signos de correspondencia de los otros pero de cuya clave de completud carecemos. Dicha obviedad de la existencia se deriva en olvido de la promesa de encuentro que inhabita el deseo y en la realización de propia identidad en la dialéctica de la ipseidad. Tanto a nivel personal como social, al oscurecerse la conciencia del acontecimiento de existir, la conciencia resbala hacia la propia banalización y la del tiempo mismo, concibiéndolo lineal. Cuando el yo censura la relación originaria que lo constituye, también pierde la referencia a su singularidad y mitifica el poder con sus conexiones evasivas, para

40 Giacomo Leopardi, El oficio de vivir (Barcelona: Seix Barral, 1992), 198.

41 Cfr. P. Ricœur, Finitude et culpbilité. L'homme faillible (Paris: Aubier-Montaigne, 1960). Este libro expone la experiencia de la desproporción conceptualizándola a nivel gnoseológico, práctico y afectivo; se trata de la matriz temprana, central y permanente a lo largo de su obra de la antropología ricœuriana, categoría donde concurren la grandeza y la fragilidad humanas.

42 V. Havel, Il potere dei senza potere, 178. 
que el yo salve su apariencia. Al estar ante un futuro mudo e indefinido, en el que no hay alteridad ni por ende responsabilidad en el presente, el sentido de toda relación consiste sólo en el manejo del aspecto técnico-estratégico del poder, como capacidad de presionar y violentar para imponerse.

Es justamente aquí donde se nota que el poder ya se ha desvinculado de su origen y de su auténtico sentido como riesgo inteligente de decisión a reabrir, cada vez de nuevo, el espacio del reencuentro, el cual es su mismo origen. A falta de ello, el poder inicia un proceso de desnaturalización que implica organizar la mentira para homologar las mentes, hacer desaparecer al yo y doblegar la alteridad bajo la presión del esfuerzo organizador por mantenerse y de la fuerza para imponerse, hasta llegar al uso metódico de la violencia. Esta torpeza del amor propio solipsista exacerba los indicios de división para administrar el conflicto radicalizándolo y así reinar.

Este juego diabólico implica eludir la significación presente del previo acontecimiento meta-político que toda sociedad implica, y cuya dramática configuración histórica de testimonios del reencuentro atraviesan sus inicuos enfrentamientos y les señalan un más-allá posible. Esta corriente testimonial, que nunca falta en las naciones, es ese mismo sustrato-signo histórico, significante de lo relacional, que llama a las puertas de la conciencia y de la libertad de los sujetos personales y sociales. Pues es lo que posibilita la vida política misma y lo que la reclama a la libertad del presente para su reinicio. Este es el núcleo de la verdadera educación. Porque la libertad en la historia no es acumulativa y cuenta siempre con la ventaja del comienzo y con la presencia de los nuevos, pero, por eso mismo, también está siempre en peligro. 


\section{5 - A modo de conclusión: Latinoamérica y el poder como acontecimiento}

Recorriendo cada uno de los cuatro parágrafos advertimos que el acontecimiento es, de diversas maneras, el núcleo articulador del proceso reflexivo llegado hasta aquí. Primero como nuevo inicio e iniciativa en la experiencia originaria del yo y del tiempo, articulados en el presente abierto. Esto es esencial para discernir lo que es una política de la administración estratégica de las fuerzas, de lo que es una política que facilita el encuentro entre los hombres sin sustituirlos. A seguir, se accede al acontecimiento como reconocimiento del sentido relacional de la pluralidad en el asentimiento y en la decisión renovada de vivir juntos, donde emerge el auténtico poder político, que no es un poder de dominar sino un poder-de-relacionar, sobre lo que ahora insistiremos. En tercer lugar, en la indicación del origen del acontecimiento en cuanto imprevisible e imprevisto, radicado en la experiencia del contraste entre el tiempo y su otro, la idea-límite de eternidad. Pero entendiendo al límite no como encierro asfixiante sino, tal como la piel, como lo que diseña el límite para que exista el saludable respiro de lo otro, respiro lanzado hacia lo abierto, hacia la vastedad de los otros y del universo, hacia la fuente originaria en la alteridad fundamental. Esta instancia personaliza la temporalidad, ligándola a la relación que fundamenta la trascendencia y la dignidad infinita del yo. Esto posibilita superar una concepción lineal del tiempo, que después imagina una historicidad que se pierde en la nebulosa de lo neutro, de lo indefinido impersonal, que va devorando generaciones al son de conjeturas extrapoladas de la situación presente. Finalmente, el acontecimiento se revela como factor esencial de la universal competencia narrativa que, a su vez, expresa la dinámica dramática de la vida humana en cuanto es búsqueda y espera a través de lo imprevisto que sobre- 
viene y define la trama. El relato instruye acerca de la racionalidad del acontecimiento.

Si tal es el hilo conductor, sin embargo, puede objetarse que la dimensión del acontecimiento es poco práctica para tener también un significado decisivo en la forma de concebir el poder y ejercer la responsabilidad política. En lo que sigue se muestra, para concluir, que la incorporación existencial de la dimensión del acontecimiento genera una conciencia crítica del sentido auténtico del poder, que verdaderamente da poder, porque es inmanente al origen del poder mismo. El consentimiento a vivir-juntos y el encuentro que en consecuencia puede llegar a suceder en la medida en que no se trate de un proyecto formal sino de un deseo real y razonable, transforma radicalmente el sentido de la acción y del conocimiento político. Para entender esto es preciso tener en cuenta que el consentimiento a vivir juntos puede tener otro canal de acceso, precisamente contradictorio con la lógica del acontecimiento del encuentro. En la década del año dos mil diez se rememora en las diversas naciones hispanoamericanas el bicentenario de la declaración de la independencia como estados nacionales. Y cabe preguntarse si lo traído hasta aquí aporta una perspectiva crítica contributiva a una rememoración innovadora. Vale considerar el estado de cosas en ese siglo XIX, que de diversas maneras se prolonga hasta el presente como una distorsión fundamental en el modo de entender y vivir la política, atestiguado por el pensador más preclaro de ese siglo, el tucumano Juan Bautista Alberdi:

Los libertadores son siempre guerreros victoriosos. Los soldados del vencedor y sus secuaces son naturalmente "liberales" [en el sentido de la libertad política que nunca puede darse por obvia]. El que vence no puede dejar de ser libertador en este sentido, que ha liberado al país del gobierno vencido (siempre digno de su caída cuando cae). Por regla general, en Sud América, 
todo libertador es militar. No hay libertador civil ni político y la razón de ello es que la espada es el solo instrumento conocido de la libertad en Sud América. Se diría que la sola libertad aquí conocida es la "libertad militar", es decir, la libertad del sable. Tal libertad es la digna hija de su madre, la espada: hija de la fuerza, su temperamento es la violencia. La fuerza convertida en libertad es la tiranía. La tiranía no es sino la libertad concentrada en uno solo: un monopolio de la libertad. ${ }^{43}$

Como puede observarse, la libertad es denunciada como el privilegio o la revancha de algunos y no como la vivencia universal de base, desde donde se construye la vida política. Se parte de la exigencia de justicia pero ésta termina siendo justiciera y vengativa al omitirse que el reconocimiento básico y, tendencialmente, lo más efectivo y responsable posible de la libertad es la primera justicia para con el hombre. A falta de esto se desploma el acontecimiento de la dignidad del yo y, con él, todo el sistema del derecho, destinado a darle curso estable al acontecimiento del encuentro. Tal como de nuevo lo expresa J. B. Alberdi, se pulveriza hasta el elemental sentido de la equidad, colocándose en la eliminación del otro el criterio de lo que hace viable la construcción política:

Se hizo un crimen en otro tiempo a Rosas de que postergase la organización para después de acabar con los "unitarios"; ahora sus enemigos imitan su ejemplo, postergando el arreglo constitucional del país hasta la conclusión de los "caudillos" ... Con "caudillos", con "unitarios", con federales, y con cuanto contiene y forma la desgraciada República, se debe proceder a su organización, sin

43 Juan Bautista Alberdi, Peregrinación de luz del día, $3^{\circ}$ Parte, 1871, X. Cfr. Idem, Edición crítico-genética y estudio preliminar de Elida Llois (Buenos Aires: Editorial UNSAM, 2009). (Entre corchetes es mío) 
excluir ni aun a los malos porque también forman parte de la familia. Si establecéis la exclusión de ellos, la establecéis para todos, incluso para vosotros. Toda exclusión es división y anarquía. ¿Diréis que con los malos es imposible tener libertad perfecta? Pues sabed que no hay otro remedio que tenerla imperfecta y en la medida que es posible al país, tal cual es y no tal cual no es ... Si tenemos derecho para suprimir al "caudillo" y sus secuaces porque no piensan como nosotros, ellos le invocarán mañana para suprimirnos a nosotros porque no pensamos como ellos ... No hay más que un medio de admitir los principios, y es admitirlos sin excepción para todo el mundo, para los buenos y para los pícaros. Cuando la iniquidad quiere eludir el principio, crea distinciones y divisiones; divide a los hombres en buenos y malos; da derechos a los primeros y pone fuera de la ley a los segundos, y por medio de ese fraude funda el reinado de la iniquidad, que mañana concluye con sus autores mismos. ${ }^{44}$

¿Qué tipo de fariseísmo es el que incentiva en nuestra frágil convivencia ese moralismo político maniqueo, que pretende valerse de la violencia para erradicar la cizaña del mal en la historia (el mal siempre es el otro), sin reparar que tal es el peor de los males? En el olvido de la esencia misma de la política, "cuya misión fundamental es la de ser mediadora y promotora de las relaciones espontáneas y los vínculos horizontales entre la inmensa variedad de personas y grupos de la sociedad", 45 subyace el prejuicio que inculca un sentido mítico e impetuoso del poder político como fuerza divina arrolladora, capaz de establecer de una vez el mecanismo de

\footnotetext{
${ }^{44}$ J. B. Alberdi, Cartas Quillotanas (Primera Carta, enero 1853). Disponible en: http://goo.gl/ilfysE

45 Carlos Hoevel, "Prólogo. De la utopía al significado", en: Aníbal Fornari et alii: Utopías y significado. Las dos banderas de la independencia hispanoamericana (Buenos Aires: Consudec-Santillana, 2016), 7.
} 
la transformación benéfica del mundo. Toda la cuestión radicaría en localizar ese mecanismo o inventar el esquema estructural que posibilitaría ser justos a bajo precio de compromiso de la libertad. Quitando del medio a quien se oponga. El despotismo político de raíz hobbesiana y su continuidad reaccionaria o revolucionaria hasta el presente tiene así, como constante, la cancelación virtual de la sociedad civil. Ésta es unilateralmente concebida como el lugar del mero conflicto, de la violencia y la irracionalidad egoísta. Por ende es abolida en su original e insustituible positividad, como lugar de libre y creativa expansión de la convivencia política (a diferencia del dominio concentrado, invasivo y despótico), más allá de la entronización totémica de poder político en el estado. Porque ahí donde el poder se concentra como dominio también se lo disputa al borde de la violencia. La lucha por la posesión del estado, tendencialmente privatizado a favor de quien lo gobierna, procura la desaparición del otro como contendiente del único lugar de presunta libertad (arbitraria). La conciencia política se desfigura así en dialéctica amigo-enemigo, la vida social en espíritu de sospecha y de temor, y el ejercicio del poder en sistemática complicidad.

¿Cuál sería, entonces, la verdadera concepción y praxis del poder como acontecimiento, tanto a nivel interpersonal cuanto a nivel político? El progreso político de la sociedad nacional, regional e internacional radica en su propio desarrollo relacional. Esto no es espontaneo sino que implica ser educados a ser parte del protagonismo de la subjetividad de la sociedad. Lo cual supone captar la razón de la sensibilidad atenta por el otro, de la maduración de la propia personalidad a través del encuentro verdadero y del descubrimiento de la belleza de la vida a través de la actitud de vivir el conjunto de las relaciones que suceden como ocasiones de cultivo de la amistad social. Esta disponibilidad por la existencia brota de la apertura de la autoconciencia personal a la relación originaria, manifiesta en la gratitud conmovida por el don de la existencia. Esta gratitud se 
descubre a sí misma en la alegría de la gratuidad vivida - al menos como deseo que intenta - desde el llano de la cotidianidad de la familia, del trabajo y de la sociabilidad más inmediata.

No se trata de un ensueño romántico distraído de la conflictividad social. Se trata de valorizar no sólo la complementariedad sino también la conflictividad de los temperamentos diversos, de las distintas perspectivas culturales, de los intereses sociales a menudo opuestos, de las injusticias que sublevan el alma, propios de la pluralidad interpersonal y de la inclinación hacia el mal que malversa nuestras relaciones con lo que es bueno. Asumir la conflictividad de hecho significa abrir los intereses y las perspectivas, que por ceguera de horizonte aparecen enfrentados, sobre una posibilidad de realización más abarcadora, digna y conveniente, donde lo que era insistencia impaciente o indignación violenta accede a su pacificado e imprevisto cumplimiento, si anticipadamente cuenta con la ayuda de otro. Como lo atestigua un ex protagonista de la violencia:

Los autores de las ciencias sociales gastan ríos de tinta intentando explicar las diversas causas de los fracasos y crisis de países como la Argentina, pero raramente se preocupan por la mayor o menor inteligencia moral (phronesis) demostrada por sus elites, en las encrucijadas históricas, para fortalecer los lazos de amistad de la nación en su conjunto. Asociadas a sistemas y regímenes totalitarios provenientes de los extremos del espectro político, las utopías del siglo XX prometieron el progreso y la felicidad en el futuro a costa de la amistad en el presente. Los resultados están a la vista, sus muertos se cuentan por centenas de millones. Pero aún cuando los muertos todavía son llorados, no son muchos los que realmente aprendieron las lecciones de la historia. ${ }^{46}$

\footnotetext{
${ }^{46}$ Héctor Leis, "Los límites de la política: acerca de la carta de Oscar del Barco", en: Lucha armada en la Argentina, (Buenos Aires: Año 2, N. ${ }^{\circ}$ 5, 2006)
} 
El origen del auténtico poder en una madura creatividad relacional, que no incurre en el dualismo de lo público y de lo privado sin más, sino que concibe toda acción individual auténtica como dotada de dignidad y de aporte a la satisfacción personal en cuanto es al par afirmativa del bien común y, por ende, no necesita disociar lo personal de lo social ni de lo político, es algo que demuestra

que la divinización de la política resulta, paradójicamente, en la destrucción de su capacidad transformadora. Cuando todo es política al final nada lo es. La política como fin de la vida se destruye a sí misma. La divinización del poder político ... trajo como consecuencia nuestro extendido desprecio hacia todo lo que limite la potencia y la supuestamente brillante capacidad de transformación del poder político. La ley, las instituciones, la división de poderes, los consensos, los derechos e intereses de los individuos y grupos y los procesos graduales que caracterizan a la evolución normal de la sociedad civil fueron considerados en general entre nosotros sólo como obstáculos que frenan la capacidad transformadora de la política. ${ }^{47}$

Desde la dimensión del acontecimiento la perspectiva relacional de la política se realiza como capacidad de potenciar y no de reemplazar el inmenso campo de experiencias humanas vitales y creativas, individuales, familiares y sociales, del que se compone la sociedad civil. El estado no es la síntesis de la sociedad, no debe intentar sustituirla sino que, para su mismo bien, necesita ayudar a que en la sociedad civil tome cuerpo la amistad social, facilitando la aproximación, el conocimiento mutuo, el encuentro creativo, la complementariedad que mejora la capacidad cualitativa de servir al conjunto de la sociedad política. Integrado por ciudadanos que

47 C. Hoevel, "Prólogo...", 5 
son actores sociales libres, el estado necesita ser fuerte no ya por su inercia creciente como exactor de la creatividad de la sociedad, sino por su equilibrada institucionalidad mediante la división de poderes y por su iniciativa correctiva enérgica de los desvíos respecto del cuidado fundamental del bien común. Atento a que nadie quede privado de los bienes humanos básicos, mediante el apoyo a la responsabilidad de cada uno para superar la propia carencia, con el concurso de la iniciativa social solidaria, procura la armonización correctiva de las distorsiones que se producen en la dinámica social, sea por injusta retribución, competencia desleal, monopolios paralizantes, etc. Entonces, esa

visión de la política orientada no a la utopía del poder sino al significado abierto y rico de la vida implica un Estado promotor del encuentro y no de la división entre los ciudadanos. El poder político tiene como función principal la recomposición de todo lo que está fragmentado, fomentando la articulación entre las distintas experiencias aisladas existentes en la sociedad civil para orientar a todo el conjunto hacia el bien común. ${ }^{48}$

La conciliación de la responsabilidad por la propia vida cotidiana con la participación política como contribución al bien común es una exigencia profunda, no sólo de unidad psíquica de la persona sino, concomitantemente, con la detección superadora de la raíz profunda de la violencia política. Esta constante de nuestra historia, desde las guerras del XIX a los conflictos del XX está íntimamente vinculada al fenómeno de la divinización del poder, que conlleva siempre un profundo desprecio del valor de la vida cotidiana. En este caso se ha perdido el sabor de la vida, de las pequeñas alegrías que proporcionan las experiencias sencillas pero grandiosas, del estudio,

48 C. Hoevel, "Prólogo...", 7 
del trabajo, de la amistad, de la vida familiar o de la participación en proyectos sociales, económicos o culturales. La prueba de que hay un sustrato generativo de la amistad social más profundo que el pacto político es que, en el caso de Argentina, habiendo pasado por severas luchas político-partidarias internas perdió sangre y tiempo, padeciendo el de otro modo inexplicable atraso en el desarrollo de su pueblo, pero permaneciendo sin fragmentarse a pesar de los intentos irresponsables de polarización.

Aquí es donde se plantea la dimensión más radical del acontecimiento y se pone a prueba la posibilidad de reinicio de la lábil Argentina-Estado desde el nivel más profundo de Argentina-Comunidad histórica cierta de sí-misma. Los argentinos no hemos sabido crear todavía una comunidad política en sentido estricto. Nuestra historia está repleta de luchas fratricidas que ni siquiera son denominadas con ese nombre, casi dando por sentado que se trata de una condición normal y no malvada de vivir la política. Hoy aparece un primer plano de derecho elemental de la ciudad-estado, hasta ahora eludido, que concierne a la justicia jurídico-constitucional y que significa juzgar y punir a todos los culpables de crímenes de los años 60-70-80, de acuerdo con la ley. Si esto no sucede, queda abierta la espiral de la violencia, porque va prevaleciendo la venganza y la ley del talión, que pretende limpiar una ofensa con otra ofensa. Si, en cambio, este primer plano se cumple de alguna manera desde la división equilibrada de poderes del estado, entonces, se realiza el pasaje del estado-lábil todavía infectado por el espiral de la violencia, al estado propiamente constitucional que eliminaría los conservantes jurídicos de tal espiral, debido a la inconstitucionalidad en la aplicación de las condenas a los militares. Al respecto señala Héctor Leis:

Sin verdad y justicia no es posible la reconciliación, ciertamente. Pero también, sin ánimo de reconciliación no se llega ni a 
la verdad, ni a la justicia, sino a la venganza. La buena memoria histórica es aquella que ayuda a una comunidad a ser amiga de ella misma, sin faltar a la verdad. Pero sepamos también que, en la Argentina de hoy, la salvación no viene de la culpabilización del otro, sino de la reconciliación con él. La superioridad moral no deriva del sufrimiento padecido sino de la capacidad de perdonar, de reconstruir la comunidad. ${ }^{49}$

Mientras que una nación constituida por individuos y actores que no saben perdonar ni ser perdonados está condenada a vivir su pasado como irreversible retorno de lo reprimido y como cobro compulsivo de deudas en el presente, repitiendo sus errores. No es por casualidad que aquellos que no saben perdonar precisen mitificar su relato del pasado para revivirlo con algunos maquillajes a la moda. En este sentido, aunque las intenciones y los sufrimientos individuales en cada campo hayan sido diferentes, los contendientes de cada bando se igualan históricamente en su incapacidad para cuidar de la comunidad nacional. Encerrados en identidades-idem, soberbias, partidistas y carentes de profundidad, contradicen la comunidad a la cual pertenecen, que pide un grado más alto de autoconciencia.

Se perfila así el asomo de la comunidad nacional, porque el odio y el resentimiento no se superan por dictamen judicial. En realidad, del espiral de la violencia anidada en el corazón sólo se puede salir a través del testimonio personal de la verdad de lo sucedido y del inicio gestual del perdón pedido y ofrecido. Pero eso llega un buen día como una gran gracia, que recrea la conciencia de la grandeza de la vida y que concierne a unos pocos individuos que desde los frentes de la violencia del pasado se encuentran en una amistad naciente en el presente. Al ser vistos y escuchados,

49 H. Leis, "Los límites de la política...", idem. 
dan razón de la esperanza aportada por el encuentro iniciado y de pronto comienza a expandirse socialmente la alegría del acontecimiento renovado de la cultura del encuentro y del poder constructivo concomitante a ella.

Financiación: Aníbal Fornari es miembro de la Carrera de Investigador Científico del CONICET (Consejo Nacional de Investigaciones Científicas y Técnicas de la República Argentina) 
TESTEM UN H O S

TESTIMONIES 



\section{SOBRE A RECEPÇÃO DA FILOSOFIA DE PAUL RICAEUR NO BRASIL}

\section{ON THE RECEPTION OF PAUL RICAEUR'S PHILOSOPHY IN BRAZIL}

Jeanne Marie Gagnebin $\mathrm{PUC} / \mathrm{SP} / \mathrm{UNICAMP}^{2}$

Quando cheguei ao Brasil em janeiro de 1978, com um doutorado sobre a filosofia da história de Walter Benjamin no bolso, devo confessar que Ricœur era para mim um ilustre desconhecido. Vinha da tradição da Escola de Frankfurt, de um marxismo não dogmático, de uma paisagem alemã em suma. Conheci o trabalho de Ricœur - que, aliás, não era tão famoso assim! - por duas vias: primeiramente, e de maneira providencial, ao orientar um trabalho de mestrado sobre a relação alma e corpo em Platão na PUC/SP.

\footnotetext{
${ }^{1}$ Este testemunho, recolhido por Patrícia Lavelle em Dezembro de 2016, instou Jeanne Marie Gagnebin a pronunciar-se sobre três questões: as circunstâncias nas quais entrou, pela primeira vez, em contato com o pensamento de Ricœur; a forma como a recepção de Ricour se fez no Brasil; e a relevância das relações entre filosofia e literatura, centrais para a pesquisa da própria Jeanne Marie Gagnebin, para esta recepção do pensamento ricœuriano no Brasil.

2 Jeanne Marie Gagnebin, PUC-SP, Departamento de Filosofia, R. Monte Alegre, 984, Perdizes - São Paulo, CEP: 05014-901 Brasil / Unicamp, Cidade Universitária Zeferino Vaz, Barão Geraldo - Campinas, CEP: 13083970, Brasil. E-mail: jmgagnebin@gmail.com
} 
A mestranda, Maria-Carolina Alves dos Santos, que depois se tornou professora na UNESP de Marília, ${ }^{3}$ citava La Symbolique du mal, em particular o belo capítulo "Le mythe de l'âme exilée et le salut par la connaissance". ${ }^{4}$ Descobri o livro com admiração. Em segundo lugar, soube do livro de Ricœur sobre Freud pelos colegas do Departamento de filosofia da Unicamp, na hoje extinta linha de pesquisa "filosofia da psicanálise" (da qual participavam, entre outros, Bento Prado Júnior, Luiz Roberto Monzani e Osmyr Gabbi Faria). O livro de Ricœur, na pioneira tradução de Hilton Japiassu de 19775 , era leitura obrigatória, longe das querelas francesas e lacanianas.

No mesmo ano, Japiassu também organizou e traduziu uma pequena coletânea de textos de Ricoeur, intitulada Interpretação $e$ Ideologias (Livraria Francisco Alves, há uma nova edição pela Editora Vozes em 2008), ${ }^{6}$ sendo que esse título é do tradutor e reflete bem as cores do tempo! Japiassu escolhe alguns artigos de Ricœur e os traduz antes mesmo de sua reunião, pelo autor, em Du texte à l'action. Essais d'herméneutique II.7 Graças a essas primeiras traduções, Ricœur entrou pela porta da teoria da psicanálise e do debate mais epistemológico sobre a hermenêutica (Habermas versus Gadamer) num círculo de leitores brasileiros bastante restrito ao meio filosófico e académico, que, ademais, podia também consultar algumas traduções já existentes em Portugal.

\footnotetext{
3 Maria Carolina Alves dos Santos, "A noção de corpo na antropologia platônica", mestrado em filosofia, PUC/SP, 1986.

${ }^{4}$ Paul Ricœur, "Le mythe de l'âme exilée et le salut par la connaissance" in Philosophie de la volonté. Finitude et culpabilité II. La Symbolique du mal (Paris: Aubier, 1960), 494-565.

5 Paul Ricœur, Da Interpretação: ensaio sobre Freud, tradução de H. Japiassu (Rio de Janeiro: Imago, 1977).

${ }^{6}$ Paul Ricœur, Interpretação e Ideologias, tradução e apresentação de H. Japiassu (Rio de Janeiro: Francisco Alves, 1978). Nova versão: Hermenêutica e Ideologias (Petrópolis, RJ: Vozes, 2008).

7 Paul Ricœur, Du texte à l'action. Essais d'herméneutique II (Paris: Seuil, 1986).
} 
Como se sabe, a tendência da "recepção" de obras literárias e filosóficas (ou de ciências humanas em geral) no Brasil segue uma dinâmica marcada pelas traduções de um lado, pelas "modas" de fora, do outro. O eclipse da filosofia ricœuriana nos anos da predominância do estruturalismo na França, aquilo que François Dosse chama de "desvio americano de 1970 a 1985", anos de ensino fecundo nos Estados Unidos, repercute também no Brasil: nesse período, Ricœur é conhecido por alguns especialistas, mas está longe de constituir uma referência mais ampla. Eu diria até que o caráter muito pedagógico e generoso de seus textos, sua argumentação decidida, mas sempre cordata e equilibrada, o afasta até hoje de certa notoriedade intelectual, muitas vezes confundida no país com posições provocativas, com afirmações peremptórias, senão escandalosas, que podem fornecer boas manchetes aos cadernos culturais dos grandes jornais. Esse senhor sério, um honesto pai de família, também tem um defeito insuportável para muitos filósofos de plantão: ele nunca renegou sua fé cristã. Se pelo menos fosse ateu, agnóstico, até mesmo judeu como Levinas ou Derrida!! Mas ser "protestante" significa que ele é ou chato ou piegas ou ambos. Mesmo que Ricour nunca se tenha cansado de separar sua fé pessoal de sua atividade filosófica, que ele sempre tenha defendido uma "filosofia sem absoluto" (isto é uma filosofia que não encontra na figura de Deus nem sua fonte nem seu fundamento), mesmo que ser protestante na França seja uma realidade distante, a anos-luz das diversas correntes evangélicas ou pentecostais do Brasil, Ricœur é mal visto, ou melhor, é sempre visto como "o filósofo cristão Paul Ricœur" - como lhe chamou a Folha de São Paulo ao anunciar sua morte em maio de 2005.

\footnotetext{
8 Ver a oitava parte do livro de François Dosse, Paul Ricoeur. Les sens d'une vie (Paris: La découverte, 1997), "L'éclipse: le détour américain, 1970-1985", 439-502.
} 
Claro, essa recusa por parte de um meio universitário francamente anticlerical e antirreligioso (Aufklärung oblige!) tem sua contraparte: a saber, uma apropriação da reflexão de Ricœur, em particular de sua ética, por pensadores e filósofos ligados ao catolicismo, especialmente nas universidades católicas (as PUCs) e numa editora ligada aos Jesuítas como a Editora Loyola. Essas últimas interpretações são de qualidade diversa, mas têm em comum uma visada ética que não consegue sempre abranger a dimensão política do pensamento ético de Ricœur, dimensão a meu ver sempre presente no autor (veja-se o belo artigo "Le paradoxe politique" 9 datado de 1957, sendo fruto de uma reflexão sobre a invasão da Hungria em 1956). Essa dimensão devia se tornar, aliás, cada vez mais clara, nas últimas reflexões de Ricour, cada vez mais interessado pelo pensamento de Hannah Arendt, a respeito da justiça e do direito ou do perdão e do esquecimento.

São sem dúvida os três tomos de Temps et Récit ${ }^{10}$ publicados, respetivamente, em 1983, 1984 e 1985, que vão recolocar Ricœur no centro do palco da filosofia francesa, não mais ocupado com exclusividade pelas querelas estruturalistas, "desconstrucionistas" ou pós-modernas (notemos que Derrida detestava a palavra "desconstrução" e Lyotard a palavra "pós-modernidade"). A notoriedade de Ricœur nos Estados Unidos ajuda seus compatriotas a prestar atenção a este filósofo francês tão pouco reconhecido, e, por ricochete, ajuda a que o público brasileiro também o faça. ${ }^{11}$ Há, no entanto, uma razão mais consistente para esse sucesso: nessa obra exigente e generosa ao mesmo tempo, temos um pensamento

9 Artigo republicado no livro Histoire et vérité. Ver Paul Ricœur, "Le paradoxe politique" in Histoire et vérité (Paris: Seuil, 1964), 294-321. Ver igualmente, sobre as posições de Ricoeur contra a Guerra da Argélia, Dosse, op. cit, 289 e ss.

10 Paul Ricour, Temps et récit. Tome 1: L'intrigue et le récit historique (Paris: Seuil, 1983); Tome 2: La configuration dans le récit de fiction (Paris: Seuil, 1984); Tome 3: Le temps raconté (Paris: Seuil, 1985).

11 Ver Dosse, op. cit., 565 e ss. 
genuinamente filosófico que se confronta com as pesquisas mais avançadas tanto nos campos da história quanto nos da teoria literária e da literatura. Isto é, Ricour leva a sério a rica ambiguidade da palavra "récit" (narrativa e narração), decorrente da tríplice significação do conceito de "história", Geschichte em alemão: o processo dos acontecimentos, a narração que recolhe, portanto lembra e interpreta esses acontecimentos em si mudos, e igualmente, as narrativas de ficção que inventam outra(s) história(s) e outra "realidade". A confrontação de um filósofo com os campos da historiografia e da teoria literária revela uma prática filosófica que não se restringe à auto reprodução de si mesma enquanto "história da filosofia", com todas suas querelas e chicanas, mas ousa se deixar questionar pelas práticas de outras ciências chamadas humanas ou sociais; e, de maneira recíproca, que reconstrói com discernimento os fundamentos e pressupostos dessas disciplinas e pode arriscar-se a questioná-los. Temos aqui uma outra concepção da filosofia que seu enclausuramento num diálogo exclusivo com sua própria tradição. Sem abdicar de sua clareza e de seu tão propalado rigor, a reflexão filosófica de Ricœur é uma exigente interrogação de conceitos, sem dúvida filosóficos (sujeito, verdade, real, ficção, para citar alguns), mas que não pertencem somente ao exercício da filosofia: pertencem ao pensamento em constante transformação das práticas artísticas e científicas. Esse gesto já estava na base do livro de Ricœur sobre Freud: se a argumentação filosófica podia ler o texto de Freud e apontar para sua grandeza, mas também para seus impasses, a repercussão da reflexão psicanalítica sobre a filosófica era ainda mais importante. Com efeito, depois de Freud, o conceito de "sujeito" não podia mais continuar, mesmo no discurso filosófico genuíno, a ser o mesmo. A leitura e a interpretação filosófica de Freud (e de outros "mestres da suspeita") obriga a reconhecer "a ruína definitiva ... do ideal cartesiano, fichtiano e, em boa parte também, husserliano de uma transparência do sujeito 
a si mesmo". ${ }^{12}$ Essa "opacidade" é rica: ela aponta para o famoso "desvio" pelas obras da cultura na auto compreensão do sujeito e, igualmente, para a importância decisiva que possui a força da imaginação (Einbildungskraft) não só nas práticas artísticas, mas também para uma teoria da ação humana. ${ }^{13}$

A mim me parece que a filosofia de Paul Ricour começou mesmo a ser reconhecida em suas verdadeiras dimensões a partir da publicação dos três volumes de Temps et Récit, volumes traduzidos primeiramente pela Editora Papirus, com três tradutores diferentes, de 1994 a $1997^{14}$ e, com nova tradução em 2010, pela Editora Martins Fontes ${ }^{15}$. Hélio Salles Gentil, autor do primeiro doutorado em filosofia sobre essa obra ${ }^{16}$, escreve uma bela introdução à tradução de Tempo e narrativa na Editora Martins Fontes, na qual situa esse livro maior de Ricour no contexto mais amplo de seu pensamento, desde sua hermenêutica dos símbolos até suas pesquisas muito precisas sobre a Metáfora viva ${ }^{17}$; Gentil resume a tese "fundamental, fundadora do

\footnotetext{
12 Paul Ricœur, Réflexion faite. Autobiographie intellectuelle (Paris: Esprit, 1995), 60 [tradução nossa].

13 A esse respeito, ver Jean Luc Amalric, Paul Ricœur, l'imagination vive. Une genèse de la philosophie ricoeurienne de l'imagination (Paris: Hermann, 2013). Jean-Luc Amalric teve durante três anos uma bolsa de pós-doutorado pela Fapesp (de março de 2013 a fevereiro de 2016), na PUC de São Paulo, participando ativamente de congressos e de bancas sobre Ricœur e ajudando a consolidar uma recepção ao mesmo tempo mais diversificada e rigorosa do filósofo.

14 Paul Ricour, Tempo e Narrativa. Tomo I: tradução de C. Marcondes César (Campinas: Papirus, 1994); Tempo e Narrativa. Tomo II, tradução de M. Appenzeller, com revisão de M. Villela-Petit (Campinas: Papirus, 1995); Tempo e Narrativa. Tomo III, tradução de R. Leal Ferreira, com revisão de M. Villela-Petit (Campinas: Papirus, 1996).
}

15 Paul Ricour, Tempo e Narrativa, vol. 1: A intriga e a narrativa histórica, tradução de Cláudia Berliner com introdução de Hélio Salles Gentil; vol. 2: A configuração do tempo na narrativa de ficção, tradução de Márcia Valéria Martinez de Aguiar ; vol. 3: O tempo narrado (São Paulo: Martins Fontes, 2010).

16 Hélio Salles Gentil, Para uma poética da Modernidade. Uma aproximação à arte do romance em "Temps et Récit" de Paul Ricour (São Paulo: Loyola, 2004); a tese foi defendida em 2001 no Departamento de filosofia da USP.

17 Paul Ricœur, A Metáfora Viva, tradução de Dion Davi Macedo (São Paulo: Loyola, 2000). 
empreendimento...: é a narrativa que torna acessível a experiência humana do tempo, o tempo só se torna humano através da narrativa". 18 A partir da publicação de Temps et récit, justamente pelo viés da narração e das narrativas, como assinala Gentil, Ricœur entra na discussão brasileira, nomeadamente nas pesquisas de literatura e de história. Isto é: ele é lido não só por filósofos profissionais, mas por escritores, teóricos da literatura, psicanalistas, ${ }^{19}$ historiadores. Como literatura e história no Brasil têm uma importância decisiva na auto compreensão cultural do país - sem querer ofender os colegas de ofício, muito mais do que filosofia! -, as reflexões filosóficas de Ricœur, justamente porque levam a sério a temporalidade das narrativas históricas e das narrativas ficcionais, penetram no debate sobre história e literatura no Brasil, renovando-o graças à sua amplitude reflexiva. Assim, por exemplo, o departamento de teoria literária da Unicamp organizou duas vezes colóquios concorridos sobre a obra de Ricœur (em 2008 e em 2015). Ousaria dizer que é justamente o gesto filosófico de reconhecer a "dignidade ontológica" 20 de outras disciplinas, diferentes da própria filosofia, que torna a filosofia de Ricœur tão vigorosa.

Para concluir, diria que essa recepção muito positiva e agora muito política da filosofia de Ricœur se repete com a publicação, em 2000, de La mémoire, l'histoire, l'oubli21, traduzido em 2007 no Brasil (por uma equipe de tradutores na Editora da Unicamp). ${ }^{22}$ Com

18 Hélio Salles Gentil, Introdução a Paul Ricœur, Tempo e narrativa, vol. 1, op. cit., p. XI.

19 Ver o livro de Sérgio de Gouvêa Franco, Hermenêutica e Psicanálise na obra de Paul Ricoeur (São Paulo: Loyola, 1995).

20 Tomo a liberdade de remeter a meu artigo "De la dignité ontologique de la littérature", in Enthymema n. ${ }^{\circ}$ IX (2013): 11-21. Trad. portuguesa no volume Paul Ricour. Ética, Identidade e Reconhecimento, Org. e tradução de F. Nascimento e W. Salles (São Paulo: Loyola, 2013), 37-55.

${ }^{21}$ Paul Ricour, La mémoire, l'histoire, l'oubli (Paris: Seuil, 2000).

22 Ricœur, A Memória, a História, o Esquecimento, tradução de A. François et. al. (Campinas: UNICAMP, 2007). 
efeito, esse livro que busca delimitar "uma política da justa memória" (segundo as palavras do autor na primeira página da obra), caiu num terreno fértil: o da discussão das políticas de memória (alguns preferem dizer de esquecimento!) dos governos brasileiros em relação aos crimes cometidos durante a ditadura militar. As distinções ao mesmo tempo firmes e finas que Ricœur opera, por exemplo, entre os conceitos de anistia, de perdão e de esquecimento (na última parte do livro) ajudam, a meu ver, a criticar com mais profundidade reflexiva um tema tão candente como a Lei da Anistia. Clareza filosófica e resistência política conseguem se apoiar mutuamente na leitura desse belo volume de 2000 .

Testemunho recolhido por Patrícia Lavelle PUC Rio 


\title{
QUAL O LEGADO PRINCIPAL DE PAUL RICAUR
} À FILOSOFIA CONTEMPORÂNEA?

\author{
WHAT IS PAUL RICEER'S MAIN LEGACY \\ TO CONTEMPORARY PHILOSOPHY?
}

Hilton Japiassu ${ }^{1}$

O eixo fundamental desse filósofo que considero um dos mais fecundos, abertos e dialógicos de nosso tempo, reside em ter tomado como seu problema próprio o da extração e interpretação do sentido (Hermenêutica) permitindo-lhe elaborar uma simbólica da consciência que se encontra na raiz mesma de todas as determinações históricas e espirituais do homem contemporâneo. Ao partir de uma análise rigorosa da vontade humana, buscou atingir e formular uma teoria do ser utilizando a fenomenologia como seu momento metodológico decisivo, a fim de detectar e analisar os problemas reais colocados pelos homens atuais no interior da História. Ao utilizar o pensamento dos outros pensadores ou cientistas como instrumento para sua própria recriação de conceitos, sua ambição foi a de pensar a totalidade do bomem (cognoscente, sentinte e agente) sem jamais reduzi-lo a uma faculdade de conhecimento.

${ }^{1}$ Hilton Japiassu† era doutorado em Filosofia pela Université des Sciences Sociales de Grenoble e Professor aposentado da Universidade Federal do Rio de Janeiro (UFRJ). 
Convencido de que o símbolo nos leva a pensar (representa um conteúdo inconsciente), fez da Hermenêutica um trabalho e uma tarefa intelectuais de decodificar o sentido oculto por detrás do sentido manifesto, notadamente nos fenômenos concernentes à vida humana e a seu destino. Donde sua Filosofia se apresentar sempre como uma atividade ao mesmo tempo concreta, temporal e pessoal, mas com pretensões à universalidade e aberta à Transcendência, pois sua esperança é uma flâmula na noite. Como um dos últimos Mâ̂tre à penser, e a fim de responder aos grandes desafios de seu tempo, não hesitou em sair do corpus propriamente filosófico para deixar-se interpelar pelos problemas de um Lebenswelt (Mundo da Vida), mas com Leben e com Welt, pois jamais deixou de consagrar sua reflexão sobre os conhecimentos novos que modificam nossas concepções do mundo, do real e do homem.

Filósofo de todos os diálogos, abriu a interrogação filosófica a uma busca frenética pelo sentido ao refletir em profundidade sobre os problemas vividos pelos homens concretos na Cidade. Donde sua obra ser considerada sem fronteiras servindo-nos de uma incrível mina de inspiração e instigando-nos a encontrar uma Ética adaptada à nossa modernidade e a seus novos desafios, notadamente o de resgatar uma utopia em sua função libertadora capaz de impedir o horizonte de expectativas de confundir-se com o simples campo da experiência. Porque o luto das visões teológicas pode se transformar numa chance para podermos refundar um projeto de futuro comum a partir do reexame permanente dos possíveis não realizados em nosso passado. Donde seu empenho em revivificar, rejuvenescer e descobrir o sopro inicial do desejo de estar sempre voltado para a ação e o presente. Donde sua busca constante de recarregar de energia uma deontologia da vontade graças a uma "teleologia do desejo". Seu pensamento, podendo ser considerado uma lição de coragem contra todas as formas de despistes, sejam eles céticos, fatalistas ou niilistas, abre-nos os caminhos de uma 
esperança exigente, convocando-nos a jamais nos esquecermos da responsabilidade e da dignidade humanas, pois, como dizia a frase de Heidegger, a ser entendida como um apelo: "a origem não se encontra atrás de nós, mas em nossa frente”. Porque, não só o indivíduo, mas também a sociedade possui um projeto, um horizonte de expectativas e de esperança permitindo-nos fazer do sentido atribuído ao passado uma fonte potencial para a construção de nosso futuro no qual o homem precisa se conceber como ser-com, cuidando de sua alma e, para ser feliz, praticando (como ensinara Sócrates) tudo o que é bom, honesto e justo, sem se esquecer do que já dizia Heráclito (séc. VI a.C.): "a mais bela harmonia nasce das diferenças".

Testemunho recolhido por Claudio Reichert do Nascimento Universidade Federal do Oeste da Bahia - Campus Barreiras 

PARTE I I

VA R I A

PART II

$\boldsymbol{V} \boldsymbol{A} \boldsymbol{R} I A$ 



\title{
ESBOÇO PARA UMA DIMENSÃO ESTÉTICA EM P A U L R I C OE U R ${ }^{1}$
}

\author{
OUTLINES OF AN AESTHETIC DIMENSION \\ IN PAUL RICAEUR
}

Vinicius Oliveira Sanfelice

UNICAMP/FAPESP ${ }^{2}$

Resumo: Este capítulo defende que a criatividade presente na linguagem poética, e exemplificada pelos enunciados metafóricos, serve de modelo para uma dimensão estética da filosofia de Ricour. Essa defesa será estruturada a partir da teoria da metáfora e da teoria da imaginação situadas em sua obra, seguindo as hipóteses de que os fenômenos criativos da linguagem formam a base para uma dimensão estética da filosofia de Ricœur, e de que há uma espécie de "metaforicidade" presente nas obras de arte ou que a metáfora é um modelo privilegiado para a análise da obra de arte.

1 Agradeço as sugestões relevantes dos revisores anônimos, bem como aos editores pela correção minuciosa - ao segui-las o capítulo tornou-se mais claro e completo.

${ }^{2}$ Vinicius Oliveira Sanfelice, Instituto de Filosofia e Ciências Humanas (IFCH), Universidade Estadual de Campinas (UNICAMP), Rua Cora Coralina, 100. Cidade Universitária Zeferino Vaz, Barão Geraldo, Campinas (SP) CEP 13083-896, Brasil. Mail: sanfelice.vinicius@gmail.com 
Procuraremos reconstruir a fundamentação ricœuriana da produção de imagens poéticas, e sua importância na redescrição da realidade e na arte. A relevância dessa teoria, assim como os elementos estéticos encontrados nela, será discutida através dos comentadores que deram primazia ao papel constituinte da imaginação e da metáfora.

Palavras-chave: Arte; Estética; Imaginação; Metáfora; Ricœur.

\begin{abstract}
This chapter argues that the creativity present in poetic language, and exemplified by metaphorical statements, can be taken as a model for an aesthetic dimension in the philosophy of Ricour. This claim will be put forward by using the theories of metaphor and imagination stemming from his work, following the hypothesis according to which the creative phenomena of language form the basis for an aesthetic dimension, and that there is a kind of "metaphoricity" present in the works of art, and also that metaphor is an ideal model for the analysis of the artwork. The paper undertakes to reassemble Ricour's theorization concerning the creation of poetic imagery and its importance to the redescription of reality and to art. The pertinence of this theory, as well as its aesthetic elements, is analyzed under the aegis of views of theorists who emphasized the formative role of imagination and metaphor.
\end{abstract}

Keywords: Art; Aesthetics; Imagination; Metaphor; Ricœur.

\title{
Introdução
}

A investigação dos aspectos criativos da linguagem faz parte do que é considerada a poética ricœuriana, incluindo aqui uma análise estrutural desses fenómenos de excesso de sentido que 
são o símbolo, a metáfora e a narrativa. O ponto que interessa é a inovação semântica, que procuro explicar na seqüência, e que é comum à metáfora e à narrativa. São diferentes inovações, e é importante dizer que na passagem de uma à outra ocorrem mudanças de vocabulário, mas até de metodologia. Para alcançar os objetivos deste capítulo, a narrativa vai ficar em segundo plano - pela minha hipótese, é necessário explicá-la por meio da metáfora. Usarei a teoria ricouriana da metáfora para pensar as obras de arte: a arte pictórica, por exemplo, criando imagens que aumentam a realidade, que acrescentam a ela por meio da ampliação icônica (condensando aspectos da realidade). A metáfora, considerada como ícone, afirmando o aspecto quase sensorial da imagem metafórica. Seu momento propriamente figurativo é um processo que conjuga invenção e recriação ao revelar dimensões da experiência que não existiam antes da obra. Essa experiência pode ser exemplificada pela redescrição que ocorre ao lermos um texto. No entanto, é preciso superar os preconceitos originados na separação entre discurso que denota e discurso que conota - a crença de que apenas o discurso científico denota a realidade, e que acaba por condenar as artes à impossibilidade de ser um discurso verdadeiro (mas apenas um discurso conotativo cujo papel é evocar sentimentos e emoções sem referência). Nada é mais prejudicial para o reconhecimento da referência produtiva da imaginação do que a afirmação desta dicotomia, pois é a questão da referência que implica a transformação no real empírico a partir da experiência virtual que o suspende. ${ }^{3}$

3 “... d'une part, on rectifie paradoxalement le positivisme que généralement on combat, à savoir le préjugé que seul est réel le donné tel qu'il peut être empiriquement observé et scientifiquement décrit. D'autre part, on enferme la littérature dans un monde en soi et on casse la pointe subversive qu'elle tourne contre l'ordre moral et l'ordre social. On oublie que la fiction est très précisément ce qui fait du langage ce suprême danger dont Walter Benjamin, après Hölderlin, parle avec effroi et admiration". Paul Ricœur, Temps et récit I (Paris: Seuil, 1983), 120. 
Esteticamente, a experiência que evidencia a ligação entre linguagem poética e imaginação produtora pode ser resumida assim: o movimento da linguagem poética em direção à realidade por meio das ficções heurísticas resulta em uma experiência que abala a referência comum, e que é a condição para a emergência da referência metafórica. A estrutura da imaginação pode ser trazida à linguagem sob a forma proposicional, e é precisamente o trabalho de síntese, gerador de um sentido completo, que pode ser entendido sob a forma predicativa. A redescrição é o resultado final do processo metafórico enquanto ficção heurística, processo que acredito servir de modelo à experiência estética da obra de arte. A dimensão estética, na filosofia de Ricœur, parece ter o objetivo de explicitar sua concepção enriquecida de linguagem. ${ }^{4}$

\section{1 - Um procedimento entre o símbolo e a metáfora}

Para o esboço de uma dimensão estética inserida na dinâmica da poética ricœuriana, sua hermenêutica do texto fornece um primeiro vocabulário de trabalho: obra estruturada como discurso; obra como projeção de um mundo. Obra como produção e trabalho de organizar a linguagem; como configuração singular, composição individual e objetivação de um discurso e de um estilo.5 Além disso,

\footnotetext{
4 "The work of art is in this way, for me, the occasion for discovering aspects of language that are ordinarily concealed by its usual practice, its instrumentalized function of communication. The work of art bares properties of language which otherwise would remain invisible and unexplored". Paul Ricœur, Critique and conviction (New York: Columbia University Press, 1998), 172.

5 Os critérios da textualidade foram apresentados em "La tâche de l'herméneutique", artigo de 1975 republicado em Du texte à l'action (1986). O tópico semântico será aproximado da hermenêutica ao tomarmos o texto (produção do discurso) como obra singular. Entendê-la como sequência fechada do discurso - obra - permite a hermenêutica textual considerar o poema como obra em miniatura e a metáfora como guia para sua compreensão.
} 
uma primeira ideia de que a obra de arte é direcionada contra o real, que visa ficcionalmente "destruir o mundo" e, por isso, demanda outra referência. Uma das estratégias do discurso que pode ser analisada e fornecer inteligibilidade sobre essa outra referência é a metáfora. Em Ricœur, a metáfora fez a transição da hermenêutica do símbolo para a hermenêutica do texto. Em um primeiro momento ela tem um objetivo preciso: articular pelo discurso a dimensão não linguística do símbolo. A relação com o logos é uma vantagem da metáfora e uma desvantagem do símbolo, que "vacila na fronteira entre logos e bios". Mas a confusão do símbolo, isto é, a impossibilidade de descrevê-lo como enunciado de predicação bizarra, ou como impertinência semântica, de modo algum significa que ele nada diz à teoria da metáfora. O artigo "Parole e symbole" torna mesmo questionável a ideia de uma completa transição em relação ao símbolo, embora a mudança de perspectiva diante dos seus limites analíticos seja considerável. O vocabulário é ampliado. O que um poema estrutura, como estratégia discursiva comparável à obra musical, é um mood; a função heurística do modelo revela um elemento comum - a ficção - no discurso científico e no discurso poético; finalmente, a dimensão referencial que é alterada pela redescrição. ${ }^{6}$

A primeira tentação a evitar, portanto, é ignorar o caminho de retorno à opacidade do simbólico. Não foi ali que a síntese figurada apareceu como solução para o "pensar a mais" dos fenômenos de excesso de sentido? A segunda tentação a evitar é repetir, ingenuamente, o percurso entre La Métaphore vive (MV) e Temps et récit (TR). $\mathrm{O}$ estudo das narrativas desenvolve uma fenomenologia da leitura

${ }^{6}$ A concepção de metaforicidade sustentada ao longo da poética ricœuriana encontra neste artigo uma formulação inicial. Ela apareceu, antes, em "La métaphore et le problème central de l'herméneutique" (1972); os conceitos analisados ali são a metáfora e o texto. A formulação plena da metaforicidade na hermenêutica é desenvolvida em "The function of fiction in shaping reality" (1979). 
- apenas implícita na teoria da metáfora - a partir de elementos relacionados à historiografia e temporalidade. Os desenvolvimentos dessa fenomenologia incluem a mímesis da ação, a identidade narrativa, a abertura ética. A metáfora não é ferramenta suficiente, embora a reconfiguração narrativa seja entendida como aplicação particular dela. Não estou abdicando das análises que norteiam uma hermenêutica literária, como a noção de mímesis, tópico comum na filosofia da arte. ${ }^{7}$ Minha proposta é separar os dois fenômenos de inovação e sustentar a metaforicidade como eixo heurístico fundamentado na transição da linguagem à imagem presente na poética ricœuriana. Não é a identificação de uma estética com essa poética.

\section{2 - A pintura do pensamento}

O ponto de partida de Ricœur é a definição de metáfora que Aristóteles fornece: transferência. ${ }^{8}$ Para essa definição há duas funções e que correspondem a duas obras, a Poética e a Retórica. Em cada uma três conceitos formam a estrutura da função. O interesse de Ricœur pela poética não é apenas pelos conceitos envolvidos, que são de uma ordem aparentemente superior (poiesis - o fazer, mímesis - o representar em ação, katarsis - o expurgar da emoção). Historicamente, segundo ele, ocorreu um engessamento, uma perda de dinâmica que afetou mais a retórica (eloqüência-prova-persuasão).

7 O leitor notará, entre outras "infiltrações" da narrativa, a implicação de Martinengo da dialética entre inovação e sedimentação ou, explicitamente, a proposta de Annovazzi. Proponho suspender a rápida passagem da questão da figuração e da imagem poética - que não corresponde a mímesis 1 - para a recepção da obra narrativa que refigura o tempo e o mundo do leitor (mímesis 3). A inclusão da refiguração obrigaria uma análise da tríplice mímesis e não a simples utilização dos aspectos criativos e poéticos de mímesis 2 . Se a proposta fosse identificar arte com mimética este capítulo seria mais que um esboço, aliás, já seria o comprometimento com um problema específico da filosofia da arte. Não é o caso.

8 Aristóteles, Poética, 1457b, p. 83. 
Ricœur se diferencia de Aristóteles no nível lingüístico em que ocorre a metáfora (da palavra para o enunciado), e na teoria do efeito de sentido operado por ela (da substituição para a interação entre os termos). Na teoria tradicional, a metáfora ocorre no processo de denominação - é o empréstimo de significado de um termo para outro. A metáfora, então, é uma figura de linguagem derivada do processo de substituição de significado entre os termos do enunciado - do figurado pelo literal.

A metáfora que pressupõe a inovação semântica está vinculada à semântica contemporânea - ocorre no enunciado, em níveis iguais ou maiores que a frase. O enunciado metafórico é explicado conforme uma teoria da tensão entre os termos do enunciado, ou seja, é um fenômeno de predicação. ${ }^{9}$ Em um primeiro momento nos deparamos com a impertinência semântica ou "predicação bizarra", o choque entre campos semânticos. No exemplo de Ricœur, "A natureza é um templo onde vivos pilares..." (do poema Correspondências, de Baudelaire), o que ocorre é a aproximação entre "natureza" e "templo", e a construção da imagem na emergência de uma nova significação: inovação semântica. ${ }^{10}$ Há o conflito entre os termos e o leitor dá a resolução, ou melhor, ele constrói a resolução na forma da figura, que é sentido e imagem unidos. A natureza como o local em que os homens, os pilares vivos, habitam... Esse processo de resolução é identificado com o que Aristóteles denominou "pôr

9 Os autores que fazem parte da teoria semântica interacionista da metáfora: A. I. Richards em Philosophy of Rhetoric (1936), Max Black em Models of Metaphors (1962), Monroe Beardsley em Aesthetics (1958), C. M. Turbayne em The Myth of Metaphor (1962), e Philip Wheelright em Metaphor and Reality (1962).

10 "Quando o poeta escreve: 'A natureza é um templo onde vivos pilares...', o é em questão não significa determinação ou caracterização, mas precisamente assimilação. Trata-se de um é sob a forma de um é-como... É preciso escrever é-como para fazer transitar o como na cópula, a fim de enfatizar o uso propriamente metafórico do verbo ser mesmo". Paul Ricœur, "Cinco lições: da linguagem à imagem", Sapere Aude, v. 4 - n.8 (2013): 33, acesso em 2 de janeiro, 2016, http://periodicos.pucminas. br/index.php/SapereAude/article/view/6426. Ver também nota xiii abaixo. 
sob os olhos"11 uma forma de "ver" que também pode ser entendida como uma "assimilação" ou um "insight". Esse "ver" está ligado, ainda, à função icônica da metáfora. A ampliação icônica (o "modo icônico de significar") é uma fórmula para construir a imagem. É o que permite entender sua dimensão verbal, ou seja, a possibilidade de trabalhar a partir de uma imaginação poética que é exigida pelo conflito dos termos. A dimensão verbal da imagem necessita de uma teoria da imaginação para ser explicitada. ${ }^{12}$

\section{3 - Imaginação e "Ver como"}

\section{1. - Kant e a imaginação produtora}

O modo de fundamentar essa imaginação poética é distinguir, respectivamente, o problema da imagem mental enquanto reprodução de um dado perceptivo e a imaginação enquanto produção de imagens. Essa tematização da imagem a partir do aspecto reprodutivo da imaginação é o equívoco, apontado por Ricœur, que dá má fama à imaginação. A reviravolta acontece com a imaginação produtora kantiana. Na Crítica da Razão Pura, a doutrina do esquematismo inverte o tratamento da imagem pela tradição filosófica, com a imaginação desempenhando um papel na constituição da realidade objetiva como função mediadora incorporada ao juízo de percepção, ou seja, o esquema transcendental, produto da imaginação, fornece uma imagem por meio da síntese do heterogêneo. Na Crítica da

11 Aristóteles, Retórica, 1405b, p. 248.

12 "Toda a vantagem de uma teoria semântica da metáfora está precisamente em considerar a imaginação pelo seu núcleo verbal e, assim, prosseguir a partir do verbal ao não verbal, e não o inverso". Paul Ricœur, "Cinco lições: da linguagem à imagem", Sapere Aude, v. 4 - n.8 (2013): 34, acesso em 2 de janeiro, 2016, http:// periodicos.pucminas.br/index.php/SapereAude/article/view/6426. 
Faculdade de Juízo, o juízo de gosto é o responsável por colocar a teoria da imaginação sob o domínio da estética e não mais da epistemologia, na produção de um prazer desinteressado. A expressão da singularidade por meio do juízo reflexivo marca a presença de Kant na dimensão estética do pensamento de Ricœur - a comunicabilidade como portadora de uma universalidade distinta daquela do juízo determinante.

Em relação aos elementos kantianos em sua filosofia, trata-se de ultrapassar o tratamento da imaginação em função da percepção para ligá-la a um uso da linguagem (metafórico). Ricœur irá incorporar o aspecto verbal da imagem, afirmando um esquematismo da atribuição metafórica, juntando o verbal e o não verbal na emergência do sentido figurativo. ${ }^{13} \mathrm{~A}$ imagem é tomada como o produto final de uma teoria semântica e o imaginário aparece implicado na linguagem. Como funciona isso? O viés semântico da imaginação pode ser compreendido como um "ver como" - é disso que trata a manutenção da ambigüidade por meio do imaginário, e que pode ser exemplificada com a figura do pato-coelho, utilizada por Wittgenstein. Passar de um aspecto da imagem - o pato - para outro - o coelho. É o que chamamos anteriormente de "insight", que Ricœur considera o aspecto sensível da linguagem poética, a imagem construída a partir dessa experiência do pensamento. $\mathrm{O}$ "ver como" está ligado a um ato de leitura de constituição intuitiva ("metade pensamento, metade experiência") fundamental para a união entre sentido e imagem. Um exemplo ricœuriano da experiência de ter uma imagem por meio de sua construção: na peça de Shakespeare, Troilus and Cressida, pode-se ver o tempo como

13 "Traitée comme schème, l'image présente une dimension verbale; avant d'être le lieu des percepts fanés, elle est celui des significations naissantes. De même donc que le schème est la matrice de la catégorie, l'icône est celle de la nouvelle pertinence sémantique qui naît du démantèlement des aires sémantiques sous le choc de la contradiction". Paul Ricœur, La Métaphore Vive (Paris: Éditions du Seuil, 1975), 253. 
um mendigo. ${ }^{14}$ A natureza icónica do sentido metafórico é também chamada de passagem intuitiva da impertinência à pertinência.

Da construção do sentido em união com a imagem torna-se necessário, para a noção de experiência estética, a passagem desses conceitos de linguagem e imaginação para a esfera da referência - $o$ que diz o enunciado metafórico acerca do real, ou seja, o extralingüístico. Ricœur introduz um vocabulário analítico ao estender a distinção fregeana entre sentido e referência para todo o discurso. É relevante também a interlocução com a teoria estética de Nelson Goodman, cuja contribuição principal é a idéia de referência generalizada. Ela sustenta, em parte, a referência metafórica e a sua função de redescrição, proporcionada por essa referência duplicada. Ricœur detém de Goodman alguns pontos relevantes para a reflexão sobre a experiência estética: 1) refazer a realidade é tarefa dos sistemas simbólicos; 2) nessa teoria simbólica a metáfora é caracterizada como um tipo de transferência, ou seja, a aplicação de predicados de uma coisa à outra; e 3) a representação entendida a partir da referência generalizada, e não como imitação por semelhança. O aprofundamento da noção de referência em direção à "verdade metafórica" será a última etapa da metaforicidade. ${ }^{15} \mathrm{~A}$ importância dessas contribuições é desconsiderar que a função poética (e estética) da linguagem tenha

14 "Soudain nous voyons-comme; nous voyons la vieillesse comme le soir du jour, le temps comme un mendiant, la nature comme un temple où de vivants piliers... Nous n'avons certes pas encore rendu compte de l'aspect quasi sensoriel de l'image". Paul Ricœur, Du texte à l'action (Paris: Seuil, 1986), 219. A passagem é a seguinte: "O Tempo, meu senhor, tem nas costas um saco, dentro do qual coloca as esmolas para o Esquecimento, esse monstro enorme da ingratidão. Esses restos são as boas ações do passado, devoradas tão rapidamente quanto foram feitas, e tão depressa esquecidas quanto foram terminadas".

15 Samuel Lelièvre (2014) entende bem como o problema da imaginação e da referência, na leitura ricœuriana de Goodman e de Wittgenstein, envolve a busca de um princípio de figuração. Ao contrário do que defende Pascal Engel (2014), pode haver um encontro da hermenêutica com a filosofia analítica que vá além do uso externo de um vocabulário análogo. Foi a defesa de uma ontologia veemente que afastou Ricœur de Goodman, e que o manteve, às vezes de forma paralela, no caminho da radicalização ontológica. 
como princípio a distinção entre conotação e denotação, e também que as qualidades de uma representação, na sua forma expressiva, sejam irreais ou efeitos subjetivos. ${ }^{16}$ Além disso, elas apontam para um preconceito específico - em conjunto com a crítica positivista de que toda linguagem que não é descritiva é emocional, há um privilégio dado ao caráter auto-suficiente da linguagem poética concedido por muitos teóricos da literatura. O problema disso é negar à linguagem poética seu poder referencial e apelar para uma auto-suficiência particular.

\section{2. - Jean-Luc Amalric e a imaginação ficcional}

O trabalho da metáfora em conjunto com a imaginação produtora é uma articulação do ficcional, resulta em uma ficcionalização da realidade. A redescrição metafórica é esse tipo de operação. A criatividade poética faz parte dela, mas também a utopia, o excesso de sentido do discurso evangélico e a representação comum à história e à narrativa - o que revela a polivalência do conceito em Ricœur. É por isso que a obra de Jean-Luc Amalric, interessado na gênese do trabalho ficcional, é um auxílio que vem renovar o vocabulário em uso. Primeiro delimitando a metáfora, ao dizer que as metáforas representam as articulações lógicas do trabalho ficcional da imaginação produtora. Ele critica esta articulação por estar limitada a uma "estática do ficcional", em que não é possível visualizarmos o viés prático da inovação semântica, revelado, posteriormente, na refiguração narrativa. O que liga as duas obras, MV e TR, na busca

16 "L'excellence esthétique est une excellence cognitive. Il faut aller jusqu'à parler de vérité de l'art, si l'on définit la vérité par la 'convenance' avec un corps de théories et entre hypothèses et données accessibles, bref par le caractère 'approprié' d'une symbolisation. Ces traits conviennent aussi bien aux arts qu'au discours". Paul Ricœur, La Métaphore Vive (Paris: Éditions du Seuil, 1975), 291. 
do trabalho ficcional da imaginação, é a mímesis criadora - mas é a teoria da leitura que confere, segundo Amalric, produtividade prática ao ficcional. Sua proposta é ligar essa mímesis a um simbolismo originário que dinamiza o trabalho semântico da metáfora, e com isso, substituir a dialética ricœuriana entre simbolismo implícito e simbolismo explícito por outra: a dialética entre um ficcional virtual (pré-reflexivo) e um ficcional atual (que corresponde ao trabalho reflexivo e semântico da imaginação poética). Para o artigo, seguindo o vocabulário proposto, é importante a afirmação de que uma "metaforicidade virtual" precederia toda invenção metafórica, ou seja, toda a metaforicidade atual. Uma modificação desta dialética revela uma contribuição ainda maior. No processo da inovação semântica está em jogo uma imaginação ficcional (em relação de atualização de uma imaginação simbólica) e uma experiência situada na junção do verbal e do não verbal. Denominada por Amalric de quase experiência ficcional, ela remete, na sua dialética, ao "ver como", implicando uma reflexão logicamente articulada que não há na experiência simbólica. ${ }^{17}$

O interesse de Amalric no trabalho da metáfora é dirigido para o esclarecimento da experiência simbólica (inclusive dentro do processo metafórico) que seria a essência de todo trabalho ficcional. Esse esclarecimento, finalmente, é tarefa de uma teoria

17 "Como o mostra Ricœur, o 'ver como' metafórico é a tradução de uma 'função imaginante da linguagem' capaz de ligar intuitivamente o sentido e a imagem, a semântica e o sensível. É ao mesmo tempo uma experiência que nos afeta - na medida em que a onda das imagens escapa a todo ato voluntário -, e um ato que efetuamos, na medida em que a compreensão de uma metáfora é um ato de leitura e de interpretação pelo qual o fluxo icônico encontra-se orientado e ordenado ... aparece, assim, que o próprio da imaginação ficcional é operar uma ruptura radical com a ordem do real. É na medida em que esta neutralização do real equivale também à neutralização de um simbolismo sempre já aí que se torna, então, possível uma refiguração da nossa experiência" (Jean-Luc Amalric, "Símbolo, metáfora e narrativa: o estatuto do ficcional em Ricœur", in Pensar Ricour: vida e narração, editado por Roberto Wu e Cláudio Reichert do Nascimento (Porto Alegre: Clarinete, 2016), 162-163). 
geral da imaginação. Nos trabalhos paralelos, ou até secundários a ela, encontram-se teorizações sobre a criatividade e sobre a invenção poética que dizem respeito à dimensão estética e ajudam a esclarecê-la - é o caso, particularmente, da leitura do esquematismo kantiano no plano da imaginação poética. Acredito que a dialética entre virtual e atual, que Amalric afirma ser essencial para uma teoria geral da imaginação, é essencial também para uma estética ricœuriana fundamentada sob a noção de metaforicidade - uma significação que opera de maneira transgressiva, porém ligada a um logos trazido à linguagem, que pode ser explicado. Não uma explicação última e unívoca, mas preservando sua polissemia sem incorrer em ininteligibilidade. É uma indicação de que a reserva de sentido, o simbólico implícito, estaria presente na obra de arte como metaforicidade atualizada.

\section{5 - Que experiência estética é possível com essas teorias?}

Uma definição explícita de experiência estética é dada em $T R$ : ela é a identificação da recepção do texto com a própria ação de lê-lo. Estética entendida na acepção grega de aísthesis como ser afetado. Nesse contexto, deve-se entender a experiência como relacionada a um objetivo específico, que é o desenvolvimento de uma hermenêutica literária em conjunto com uma fenomenologia da leitura. As reflexões sobre obras de arte, em um sentido mais geral estão dispersas na filosofia de Ricœur - por exemplo, no livro $A$ Crítica e a Convicção e na entrevista "Arte, linguagem e hermenêutica estética". Os exemplos reunidos falam de uma redescrição inventiva da realidade, e possuem a característica de serem descritos por meio dos mesmos conceitos: metaforicidade, imaginação poética e ampliação icônica. É essa unidade dispersa que permite falar sobre uma dimensão estética. 
Os exemplos. Primeiro, há uma escultura de Henry Moore (intitulada Nuclear Energy de 1967) descrita como polissêmica ao reunir diversos significados. Segundo Ricour, essa "esfera explodida" pode representar o crânio de um sábio, um átomo que explode ou a própria terra - ele fala de uma capacidade de intensificar esses significados ao condensá-los, ao reuni-los. ${ }^{18}$ A análise ricœuriana defende também que a escultura ultrapassa os recursos tradicionais do figurativo, e que deve, portanto, ser descrita como polifigurativa. Em outro exemplo, ao dizer que Cézanne nunca pinta a mesma montanha (na série de pinturas que compõem Mont Sainte-Victoire and the Viaduct of the Arc River Valley, 1882-85) e que o pintor realiza um acréscimo em relação à representação pura e simples de um objeto da realidade, ele afirma a idéia de ruptura com o real e de uma função de ampliação icônica, própria ao enunciado metafórico. ${ }^{19}$ Mas o que significa restituir à montanha, por meio da ampliação icônica, a sua singularidade própria? A singularidade é referida à doutrina kantiana do gênio e ao juízo reflexivo: é a criação, por parte do artista, de regras próprias a partir das regras fornecidas pela natureza, isto é, o modo exclusivo com que ele comunica universalmente a experiência singular, violando - de maneira ordenada - as regras da natureza. Penso que até aqui a hermenêutica ricouriana é um

18 "This would be comparable to the density of certain forms of language, such as metaphor, in which several levels of meaning are held together in a single expression. The work of art can have an effect comparable to that of metaphor: integrating levels of sense that are overlaid, preserved and contained together". Paul Ricœur, Critique and Conviction (New York: Columbia University Press. 1998), 172.

19 "I am thinking, for example, of Cezanne's stubbornness confronting the Sainte-Victoire mountain: why always paint the same view over and over? Because it is never the same. It is as if it were necessary for Cezanne to do justice to something that was not the idea of the mountain - not the terms we use in general discourse - but that represented the singularity of this mountain, here and now; this is what has to be rendered, what insists on receiving the iconic augmentation that the painter alone can confer upon it". Paul Ricœur, Critique and Conviction (New York: Columbia University Press, 1998), 178. 
guia seguro, justamente porque se mantém nos limites do textual e da (poli-) figuração. Como ir além?

Ricour acredita que a idéia de acréscimo pode ser estendida também à pintura não figurativa e à música. A pintura abstrata é um primeiro caso-limite. ${ }^{20}$ Não apenas a teoria da metáfora ricœuriana, mas a idéia de jogo de linguagem não verbal ou de uma lógica da imagem pictórica do ponto de vista semântico parece, até aqui, insuficiente ou impossibilitada de fornecer uma coerência a essa extensão que deseja percorrer. E o caso da música, assim como o da pintura não figurativa, é importante por sinalizar o polo mais extremo de retirada do real, onde a função de representação é mais tênue. ${ }^{21}$ Talvez seja por isso que um vocabulário heideggeriano apareça sob o nome de manifestação de mundo, conforme a definição de Gadamer. Para dar conta da pintura abstrata obrigatoriamente deve-se fazer um ajuste aqui, aprofundando essa manifestação ou inserindo outras abordagens. De qualquer forma, essa é a primeira dificuldade que deve ser enfrentada. A segunda é o entendimento de que toda obra de arte, inclusive a musical, corresponde a um humor

20 "One could say that nonfigurative painting freed what was in reality already the properly aesthetic dimension of the figurative, a dimension that remained veiled by the function of representation that fell to pictorial art. And it is when the concern with the internal composition alone was disconnected from the representative function that the function of manifestation of a world was rendered explicit; representation once abolished, it becomes obvious that the work expresses the world in a manner other than by representing it; it expresses it by iconizing the singular emotional relation of the artist to the world, which I have called the mood". Paul Ricœur, Critique and Conviction (New York: Columbia University Press, 1998), 181.

21 "But music permits us to go even further in this direction than painting, even nonfigurative painting. For the latter often contains figurative remnants. I am thinking, for example, of Manessier's four magnificent paintings: The Passion ... In these works there is something like an allusion to reality: forms of the cross against red, orange or pink backgrounds; the figuration is allusive, even recessive, but not entirely absent. In music, by contrast, there is nothing of the sort. Each piece possesses a certain mood, and it is as such, without representing anything of the real, that it establishes in us the corresponding mood or tone. Paul Ricœur, Critique and Conviction (New York: Columbia University Press, 1998), 174. 
( $\operatorname{mood}$ ), a uma emoção perdida, restituída e preservada pela obra. ${ }^{22}$ Ricœur afirma que as tonalidades afetivas (Stimmungen), o humor próprio de uma peça musical, são criadas: cada peça gerando a sua cadeia de tonalidades. O exemplo que ele usa é a recriação do canto dos pássaros no São Francisco de Assis de Messiaen. A dificuldade está em saber que tipo de figuração estaria presente nessas disposições de humor que aparecem, ou o que significa "abrir" o espaço emocional onde os sentimentos serão figurados, e o que seria esta transfiguração dos sentimentos. A capacidade de uma obra de arte significar e transformar a realidade, afirma Ricœur, é maior nessas expressões que revelam sua pureza em relação ao real. Dito de outra forma, quanto mais afastada, mais se percebe o poder de influência e de não superficialidade da arte.

\section{6 - Extensões}

Existem outras implicações que interessam, no sentido de ampliarem as experiências estéticas possíveis. Ricœur utilizou-se de sua teoria mimética para aproximar sua noção de narrativa à de arquitetura. ${ }^{23}$ Sugerindo uma relação entre a temporalidade da narrativa e a espacialidade da arquitetura, ele afirma uma configuração estruturante envolvida em ambas, sendo a primeira uma inscrição no tempo e a segunda uma edificação do material no espaço. Nessa relação de analogia, a pré-figuração é a necessidade vital de habitar

22 "What the artist restores is the mood that corresponds to the singular, prereflexive, antepredicative relation to the situation of a given object in the world. The mood is like a relation outside of the self, a manner of inhabiting a world here and now; it is this mood that can be painted, put into music or into narrative in a work, which, if it is successful, will have the right kind of rapport with it". Paul Ricœur, Critique and conviction (New York: Columbia University Press, 1998), 179.

23 Ricour, "Architecture et narrativité", in Urbanisme 303 (novembre-décembre 1998): $44-51$. 
que impulsiona a construção (etapa de configuração do espaço) e que precede o "habitar como resposta" (a refiguração do ambiente). Além disso, a tipologia defendida por Nelson Goodman da representação em arquitetura - proposta pelo seu neo-representacionalismo (1988/2009) - e a "nova teoria da representação", que Giannotti defendeu a partir das obras de David Hockney (1983/2010), sugerem ao menos uma porta de entrada ao debate contemporâneo. ${ }^{24}$ Ricœur também realizou uma análise das aproximações freudianas à teoria da arte. A análise da poesia foi elogiada por certo rigor analítico. No entanto, critica o ensaio sobre a pintura de Da Vinci, porque ele buscaria explicar o mecanismo da criação estética pela biografia do artista. Afastando-se de análises técnicas ou estruturais, Freud pretenderia explicar a Mona Lisa pelas inibições do pintor. Trata-se de um confronto hermenêutico com a interpretação que é focada apenas no arqueológico: privilegiar o significado que está ausente na obra de arte, no caso as relações de Leonardo com sua mãe, segundo Ricœur, é como duplicar o enigma. Também aponta para os limites da psicanálise, e com isso, para a necessidade de superá-la com o objetivo de dar conta da "superabundância simbólica”. Uma terceira implicação é tomar a dialética de inovação e sedimentação para pensar os movimentos artísticos. É o que Alberto Martinengo ${ }^{25} \mathrm{faz}$, ao considerar que eles também comportam o processo de inovação semântica. Ele é estendido aos movimentos artísticos na forma de um novo cânone que surge da violação ordenada do paradigma artístico tradicional, expandido ou transformado em sua estrutura. Antes de erradicar o cânone

24 O artigo de Goodman, "Como os edifícios representam" (1988), foi republicado em Arte em Teoria: Uma Antologia de Estética (2009, 25-37). A conferência de Giannotti é de 1980, publicada em 1983 com o debate que reuniu artistas e críticos, e republicada em 2010.

25 Alberto Martinengo, "Metaphor and Canon in Paul Ricœur: From an Aesthetic Point of View", in Proceedings of the European Society for Aesthetics 2, (2010): 302-311. 
anterior, a inovação testa seus limites transgredindo-os. Ao usar o exemplo do abstracionismo de Kandinski, Martinengo afirma que é um movimento que se coloca ao lado do mundo, em competição com ele; mais do que abstração, suas obras parecem estar desligadas de elementos da realidade natural, constituindo mais propriamente outra proposta de realidade. A radicalidade desse estilo, em sua experimentação, rompe com o princípio naturalista da tradição na busca de um canal privilegiado para a construção de significados.

\section{7 - Qual dimensão estética?}

Tentativas de unificar as reflexões ricœurianas sobre as obras de arte, ou mesmo pensar uma dimensão estética em sua obra, são encontradas em Eugene F. Kaelin, "A estética de Paul Ricœur: sobre como entender uma metáfora", e em Jérôme Cottin, "Metáfora e estética no pensamento de Paul Ricœur". Ambos ressaltam o aspecto disperso dessas reflexões e propõem uma interpretação integralizada, isto é, como se o tema do excesso de sentido a partir do discurso figurado, em particular da metáfora, estivesse impulsionando os interesses da poética em direção a uma dimensão estética que restou nuançada. Uma breve análise dos artigos é útil para diferenciá-los no modo como integram o tema estético ao resto da obra, e do modo como ele foi trabalhado pelos autores que constituem uma "escola italiana" sobre o tema. ${ }^{26}$

$\mathrm{O}$ artigo de Cottin tem um fundo biográfico e ensaístico, ilumina o interesse pessoal de Ricour pela arte apresentando alguns conceitos relacionados com esse interesse (semelhança, distanciação). Embora

26 Após os trabalhos de Rita Messori sobre metáfora e estética, Annovazzi e Martinengo desenvolveram suas ideias sobre o tema estética/metáfora/ em outros artigos - ver a bibliografia. 
seu resumo da hermenêutica identifique as contribuições da poética ricœuriana, a textualidade não sofreria modificação quando relacionada com a reflexão sobre a arte. A exceção caberia aos fenômenos teológicos de excesso de sentido. Trata-se, portanto, de uma dimensão estética e religiosa. Esta conclusão parcial resulta da análise tímida do que permite a interpretação tanto do "mundo do texto" quanto da obra de arte - a imaginação. Alterá-la para incluir a reflexão estética é, mesmo sem formular uma teoria geral da imaginação, assumir uma reformulação conseqüente da hermenêutica. Cottin não propõe a alteração, antes procura os indícios do trabalho que Ricœur poderia ter realizado a partir de interesses harmonizáveis. O artigo de Kaelin assume uma estética que vai se alterando segundo fases específicas do pensamento de Ricœur - Aristóteles, Freud e novamente Aristóteles. Sua concepção de metáfora reforça as conotações da catarse psicológica envolvida na recepção do texto no limite de quase naturalizar a tensão da referência metafórica. Ele também analisa a tríplice mímesis para concluir que a discussão principal é sobre a significação ontológica do tempo, e que TR foi escrito como um tratado de ontologia fundamental. No final do artigo propõe que a tensão causada pela referência metafórica deve ser entendida como a luta entre "terra" e "mundo". Mas essa luta não precisa ser descrita metaforicamente como Heidegger fez. Assim é possível compreender que, ao afirmar "que a mais forte impressão crítica para o seu leitor [de Ricœur] é de que ele seguiu demasiado, e indiscriminadamente, a tradição", o exemplo de Kaelin não seja em relação ao próprio Heidegger ou mesmo Gadamer (Habermas poderia ter notado). O exemplo é a catarse. O grande mérito do artigo foi receber uma resposta generosa da parte de Ricœur. ${ }^{27}$ Se Kaelin interpreta a narrativa regressivamente até o

27 As críticas de Kaelin são encontradas em: Lewis Edwin Hahn, A Filosofia de Paul Ricœur (Lisboa: Instituto Piaget, 1997), 180-183. Da resposta de Ricœur destaco: "Tornarmo-nos os leitores de nós mesmos, sob a orientação do texto, constitui a maior ambição que pode ser atribuída ao empreendimento literário 
confronto com Freud, Ricœur não assume a limitação dos aspectos estéticos da metaforização à afetividade das emoções e ao prazer. E reforça a transformação do mundo do leitor como uma ampla metaforização. A clarificação das emoções seria apenas um momento específico dessa transformação.

Os dois artigos, realizados a partir de sugestões efetivas, distintos em pretensão, integram uma noção estética pouco crítica, no sentido de que sugestões dispersas exigem a reconstrução da teoria primária. O passo além de um esboço será questionar os motivos da dimensão estética restar nuançada, o que impede de destacá-la, e que benefícios isso traria para a filosofia de Ricœur. Mesmo em uma obra que modifica seus métodos filosóficos, propícia a um recorte específico, a classificação hipotética por fases ou interesses declarados resulta em segundas sugestões. "Logique herméneutique?" (2010), comunicação de 1978 publicada em 1981, é mais que sugestiva sobre o papel que a compreensão estética (verbal ou não verbal) desempenharia em uma hermenêutica renovada, disposta a enfrentar suas ambiguidades em relação à teoria crítica e ao radicalismo ontológico heideggeriano.

Tratamento que sugere algum tipo de renovação hermenêutica foi realizado por Claudia Elisa Annovazzi ${ }^{28}$, que também assume a possibilidade de uma teoria estética. Ela afirma que a análise ricœuriana da metáfora, em um primeiro momento, limita-se à dimensão lingüística das obras (a relação obra-leitor) e não desenvolve de maneira direta a relação obra-autor. Partindo disso, Annovazzi argumenta que o tratamento do estético em Ricœur é essencialmente do ponto de vista da percepção e não da criação. Há, portanto, a necessidade de se construir o ponto de vista da criação. Ela sugere

sob a égide do excesso de significação e o tema relacionado da metaforicidade" (188-189). O preenchimento completo de um esboço deverá responder sobre o empreendimento da obra de arte.

${ }^{28}$ Claudia E. Annovazzi, "Tra parola e imagine: prospettive estetiche nella poetica di Paul Ricœur", in Entyhema IX (2013): 90-103. 
que a função do autor seria a de dar um testemunho de dimensões do real que a descrição objetiva não alcançaria, apoiando-se aqui na referência cruzada entre história e narrativa e nos empréstimos mútuos que realizam para representar de forma adequada o seu objeto, especificamente, a identificação da função de representação na história e no testemunho. Na interpretação que Annovazzi faz da emoção restituída pela obra de arte, o artista expressaria a representação simbólica de uma ausência, reconstruindo, a partir de vestígios, a experiência singular que experimentou. O exemplo é de um autor que vivencia o holocausto e é chamado a dar testemunho da sua experiência - vivenciar e ser chamado envolvem aplicações possíveis desse entendimento estético na filosofia de Ricœur, assim como a dialética entre ideologia e utopia na alteridade ética e religiosa. Essa é uma possibilidade: uma hermenêutica do testemunho. 29

Uma segunda possibilidade, proposta por Annovazzi, é a de fundamentar uma estética da criação sob a figura do autor e por meio da imaginação produtora, em analogia à espécie de estética da recepção esquematizada sob a figura do leitor (e adicionando o vocabulário da metáfora ao da intriga narrativa). Ela afirma que se assumirmos o termo "estético" em um sentido mais amplo, que inclua também a dimensão da criatividade artística, já se encontraria o âmbito propriamente estético da filosofia de Ricœur. ${ }^{30}$ Ampliar, aqui, é não

29 A utopia do imaginário abre a possibilidade de comunicação com o outro, e a pergunta é se a imaginação não poderia, ainda, representar uma mediação com o Outro por excelência, através da transcendência religiosa. A utopia é relacionada com uma "... funzione di ridescrizione metaforica dell'arte, nella misura in cui essa si inscrive nella fruizione ideologica del reale per metterla in discussione e aprirla a nuove possibilità di relazione con il mondo e con gli altri. Essa svolge quella funzione $u$-topica di proiezione nel non-luogo della finzione delle diverse potenzialità nascoste nella fruizione quotidiana del reale". Claudia E. Annovazzi, "Tra parola e imagine: prospettive estetiche nella poetica di Paul Ricœur", in Entyhema IX (2013), 102.

30 "La ragione per cui Ricoeur non ha mai elaborato un'estetica dell'immagine dipende perciò in larga misura dall'accezione etimologica restrittiva con cui egli ha assunto il termine 'estetico', associandolo alla questione dell'aisthesis greca e 
reduzir-se à sua primeira definição de estética na acepção grega de aísthesis. Annovazzi assume o cuidado que Ricœur tomou de não identificar o âmbito poético com o estético - afirmou, em seu artigo sobre a hermenêutica bíblica, a separação entre eles com a intenção de preservar a função poética como uma capacidade discursiva e imaginativa de modificar a realidade.

Não está claro que tipo de apelo à função poética ocorre no objetivo de fundamentar a criatividade artística. Se existe uma relação mais proveitosa, ou que mais bem justificada, entre a poética ricœuriana e uma estética. Mas será um bom começo tomar em amplitude a releitura do mundo-da-vida operada pela metaforização e testá-la em outro vocabulário. Cabe ainda atualizar a metaforicidade com os desenvolvimentos recentes da filosofia da imagem - propostas esboçadas por Annovazzi e Martinengo. É uma ousadia produtiva retornar à questão da imagem quando Ricœur desenvolveu a reabilitação da imaginação para além dela - mas não o fez para distinguir a imagem-cópia da imagem-ficcional? A busca por uma dimensão estética é menos dispersa que sua própria sugestão, ou intenção, por parte de Ricœur. Na espera das palestras inéditas sobre a imaginação (que devem alterar a recepção da sua teoria da imaginação - como?), nas tentativas recentes de encontro com a filosofia analítica ou com a teoria crítica, a unidade encontrada até agora foi a do esboço. Alguns escolhem traços mais nítidos, outros apelam para cores impressionistas, difusas. Cabe ao leitor, agora, ver.

quindi al problema della percezione e della ricezione dell'opera da parte del suo fruitore. Ma se assumessimo il termine in un accezione più ampia, che comprendesse nell'estetica anche la dimensione della creatività artistica, non c'è dubbio che anche la poetica ricoeuriana rientrerebbe nell'ambito dell'estetica. Questo inserimento offrirebbe non solo nuove prospettive d'interpretazione dell'opera ricoeuriana, ma anche nuovi spunti di riflessione per le questioni sollevate in campo estetico come, in particolare, le indagini sull'ontologia dell'immagine". Claudia E. Annovazzi, "Tra parola e imagine: prospettive estetiche nella poetica di Paul Ricœur", in Entybema IX (2013), 93. 


\section{Bibliografia}

Amalric, Jean-Luc. Paul Ricour, l'imagination vive: Une genèse de la philosophie Ricœurienne de l'imagination. Paris: Editions Hermann, 2013.

. "Símbolo, metáfora e narrativa: o estatuto do ficcional em Ricœur", in Pensar Ricour: vida e narração, editado por Roberto Wu e Cláudio Reichert do Nascimento. Porto Alegre: Clarinete. 2016, 131-167.

Annovazzi, Claudia E. "Le Témoinage des Images: Une Interprétation Esthétique de Ricœur." In Proceedings of the European Society for Aesthetics, 3 (2011): 51-66.

—. "Tra parola e imagine: prospettive estetiche nella poetica di Paul Ricœur." In Entybema IX (2013): 90-103.

Aristóteles. Poética. Lisboa: Fundação Calouste Gulbenkian, 2008.

—. Retórica. Lisboa: Imprensa Nacional - Casa da Moeda, 2005.

Cottin, Jérôme. "Metáfora e estética no pensamento de Paul Ricœur". In Artefilosofia 15 (dezembro 2013): 25-33.

Engel, Pascal. "Y a-t-il eu vraiment une rencontre entre Ricœur et la philosophie analytique?", In Études Ricouriennes / Ricour Studies 5, 1 (2014):124-141.

Gentil, Hélio Salles. Para uma poética da modernidade - uma aproximação à arte do romance em Temps et Récit de Paul Ricour. São Paulo: Edições Loyola, 2004 .

Giannotti, José Arthur. "A nova teoria da representação". In Artes \& ensaios 20 (2010): 140-167.

Goodman, Nelson. Ways of Wordmaking. Indianapólis: Hackett, 1978.

—. Linguagens da Arte. Lisboa: Gradiva. 2006.

Hahn, Lewis Edwin. A filosofia de Paul Ricœur. Lisboa: Instituto Piaget, 1997.

Kant, Immanuel. Crítica da Razão Pura. Lisboa: Calouste Gulbenkian, 2001.

—. Crítica da Faculdade do Juizo. Rio de Janeiro: Forense Universitária, 2012.

Lelièvre, Samuel. "Langage, imagination, et référence. Ricœur lecteur de Wittgenstein et Goodman. In Études Ricœuriennes / Ricœur Studies 5, 1 (2014): 49-66.

Martinengo, Alberto. "Metaphor and Canon in Paul Ricœur: From an Aesthetic Point of View". In Proceedings of the European Society for Aesthetics 2, (2010): 302-311 .

—. "Le travail de l'image. Métaphore et performativité chez Paul Ricour". In Klesis - Revue philosophique (2013): 23-34.

—. "From the linguistic turn to the Pictorial turn - Hermeneutics facing the "Third Copernican Revolution'", In Proceedings of the European society for Aesthetics, 5 (2013): 302-312.

_. "Parlare per immagini. Linguaggio, visione, metaforizzazione", In La Deleuziana n. ${ }^{\circ} 0$ (2014): $30-43$.

Messori, R. "Paul Ricœur e i paradossi dell'estetica". Studi di estetica, XXVIII, 22 (2000): 113-134.

Moura, V. (org.), Arte em Teoria: Uma Antologia de Estética. Braga: Húmus, 2009. 
Ricœur, Paul. La symbolique du mal. In: Philosophie de la volonté II. Paris: Aubier, 1960.

_. "La métaphore et le problème central de 1'herméneutique". In Revue de Métaphysique et de Morale 70 (1972): 93-112.

—. La Métaphore Vive. Paris: Éditions du Seuil, 1975.

—. "Logique Herméneutique". In Écrits et Conférences 2: Herméneutique. Paris: Seuil, 2010, 123-196.

—. "Parole et symbole", In Revue des Sciences Religieuses, vol. 49, n. ${ }^{\circ}$ 1-2 (1975): 142-161.

—. "The function of fiction in shaping reality". In Man and World 12, 2 (1979): 123-141.

—. Temps et récit. Tome I: L'intrigue et le récit historique. Paris: Seuil, 1983.

_. Du texte à l'action. Essais d'herméneutique II. Paris: Seuil, 1986.

- A Ricour Reader: Reflection and Imagination. Mario J. Valdes (ed.). Toronto: University of Toronto Press, 1991.

—. "O processo metafórico como Cognição, Imaginação e Sentimento". In Da Metáfora. São Paulo: Editora da PUC-SP \& Pontes, 1992, 145-160.

—. Autobiografia intelectual. Tradução de Sílvia Menezes. Lisboa: Piaget, 1995.

—. "Architecture et narrativité". In Urbanisme 303 (novembre-décembre 1998): 44-51.

—. Critique and conviction. New York: Columbia University Press, 1998.

—. "Arts, language and hermeneutical aesthetics: Interview with Paul Ricoeur", In Philosophy \& Social Criticism (October 2010): 935-951.

—. "Cinco lições: da linguagem à imagem", In Sapere Aude v. 4 (2013): 12-36.

Taylor, George H. "Ricœur's Philosophy of Imagination". In Journal of French Philosophy 16 (2006): 93-104.

Financiamento: Este capítulo não seria possível sem o suporte da Fundação de Amparo a Pesquisa do Estado de São Paulo (FAPESP), que financia a pesquisa de doutoramento de Vinicius Oliveira Sanfelice, por meio do processo 2015/27009-3. 
Reseña (Book Review) de Tomás Domingo Moratalla, Agustín Domingo Moratalla (ed.), Bioética y hermenéutica. La ética deliberativa de Paul Ricœur (Actas del Congreso Internacional, Valencia, España, febrero 2013), Editorial Hermes, Valencia, 2014, pp. 429 (libro electrónico-Amazon) ISBN: 978-84-96657-33-5

Marcos Alonso Fernández ${ }^{1}$

Una vida y obra como la de Paul Ricour (1913-2005) bien merece ser recordada. Pocos filósofos a lo largo de la historia han asumido con mayor fidelidad y entrega la tarea del pensamiento, y a estos grandes ejemplos debemos volver una y otra vez para aprender y re-aprender qué es realmente la filosofía. Con motivo del centenario del nacimiento de Ricour apareció el presente trabajo, Bioética y hermenéutica. La ética deliberativa de Paul Ricour, editado por Tomás Domingo Moratalla y Agustín Domingo Moratalla.

En esta obra podemos observar tres vertientes bien diferenciadas, si bien estrechamente comunicadas y en perpetua convergencia: la aportación de Ricœur a la hermenéutica, su contribución al campo de la ética aplicada, y la relevancia de su obra para la bioética. En torno a estas tres líneas y sus entrecruzamientos giran todos los

${ }^{1}$ Marcos Alonso Fernández, Departamento de Filosofía del Derecho, Moral y Política II de la Universidad Complutense de Madrid, Ciudad Universitária, Plaza Menéndez Pelayo, s/n, 28040 Madrid, España. Mail: marcs.alonso@gmail.com 
trabajos compendiados en Bioética y hermenéutica. La ética deliberativa de Paul Ricour.

Entre los trabajos de la primera línea, dedicada a la hermenéutica, cabría destacar la clara introducción a esta base hermenéutica del pensamiento de Ricœur por parte de Marcelino Agís Villaverde en "Fundamentos hermenéuticos de la ética de Paul Ricœur". Encontramos interesantes reflexiones sobre la naturaleza de testimonio y confesión en "Du témoignage et de l'aveu", de Johann Michel, lo mismo que sobre la base bíblica de algunas concepciones éticas ricœurianas en "Palabra bíblica e autonomía ética en Paul Ricœur" de Michel Renaud. Dos sugerentes trabajos sobre la comprensión hermenéutica de la enfermedad son "Santé, médecine et maladie. Lecture comparative des écrits topiques de Paul Ricœur et de Georges Canguilhem" de Gilbert Vincent y "Expliquer, comprendre et vivre la maladie" de Jérôme Porée.

La segunda línea de aportaciones, centradas en el aspecto ético del pensamiento de Ricour, tiene también una fuerte representación en la obra. Un trabajo a destacar es, por supuesto, la aportación de Diego Gracia, quien examina los distintos niveles de la reflexión ética ricœuriana en "Supra-ética" y "pequeña ética" en Paul Ricœur. El trabajo "Sagesse pratique, soin et responsabilité: les ressources éthiques de la philosophie de Paul Ricœur" de Lazare Benaroyo es también una brillante aportación al libro. En este importante trabajo se presenta a la ética ricœuriana dentro de las llamadas éticas del cuidado, mostrando asimismo la productividad de las categorías de Ricœur en este campo. Una aproximación más fenomenológica y metafísica es la de Gonçalo Marcelo "A Ética como Exploração do Possível"; una línea en la cual también se inserta el trabajo de Daniella Iannota "Por une éthique de la vie heureuse: Paul Ricœur". En el intersticio entre ética y bioética encontramos el trabajo de César Correa Arias "Mi sufrimiento contado por otros. Los procesos de narración en salud desde una ética hermenéutica". Estos trabajos 
dan una muestra de las posibilidades de la ética ricœuriana, un terreno fértil que todavía puede dar mucho de sí.

Es precisamente la línea bioética la que acapara una mayor parte de trabajos. Encontramos en esta línea importantes trabajos como: "Ricour, the bioethics of happiness and related delusional states" de Alison Scott-Baumann, donde se apunta una reflexión sobre la felicidad y su importancia en el ámbito sanitario; "A humanidade do homem. Do neuronal à ética da deliberação" de Paula Ponce de Leão, trabajo en el que se pone en conexión la neurociencia con la ética de la deliberación ricœuriana; o "A importancia de P. Ricœur para o ámbito da decisäo em bioética: imaginação narrativa e sabedoria prática" de María Luisa Portocarrero, donde se reivindica con fuerza la vigencia y actualidad de Paul Ricœur en la reflexión bioética.

Esta rápida referencia a alguno de los estudios contenidos en Bioética y hermenéutica. La ética deliberativa de Paul Ricoeur puede darnos una buena idea de lo que esta obra nos ofrece. No obstante, comentaré con más detalle algunos artículos en los cuáles encontramos aspectos particularmente interesantes.

El trabajo que abre el libro es "Crítica y corazón: la ética narrativa de Paul Ricour", de Agustín Domingo Moratalla. El trabajo de A. Domingo, uno de los más completos e interesantes de la obra, se centra en exponer la ética narrativa de Ricour, justificando el adjetivo bajo la que se presenta dicha ética. A. Domingo explica cómo la filosofía de Ricœur estaba orientada desde un principio hacia la ética con sus trabajos sobre la voluntad, si bien esta ética implícita solo se volvió explícita cuando se abrió al diálogo con otros autores como Marcel o Jaspers. Es así como Ricœur acabará abanderando la "transformación narrativa de la fenomenología" en los años setenta y ochenta, sentando las bases para la que sería una fuerte tradición filosófica. En este sentido, los análisis ricœurianos de la narratividad son clave a la hora de llevar a cabo una ampliación - que no una anulación - de la racionalidad, que a su vez nos permite entender 
mejor a un sujeto que pasa a comprenderse como descentrado y necesariamente parte de un relato. La importancia de la identidad narrativa para la identidad moral no puede ser subestimada, según A. Domingo, pues es el único método que se acerca a dar verdadera cuenta de la complejidad inherente a los asuntos humanos. La ética de Ricœur, acabará diciendo A. Domingo, será por tanto una ética del reconocimiento, una ética de la responsabilidad, y, por tanto, una ética prudencial que recoge la indispensable categoría aristotélica de la phronesis.

Fernanda Henriques lleva a cabo un sugerente análisis titulado "La ficción narrativa de la identidad narrativa de Paul Ricœur", donde muestra cómo Ricœur pone de manifiesto la constitutiva fragilidad y vulnerabilidad humana, junto a sus consecuencias éticas. La identidad se basa en una compleja permanencia en el tiempo, del cual es ejemplo privilegiado el caso de la promesa. Este tiempo humano vendría a ser un entrecruzamiento del tiempo fenomenológico y tiempo cosmológico, que sin embargo nunca permite la construcción de una identidad cerrada y perfectamente acabada. F. Henriques reitera, como otros trabajos del libro, la importancia que estas averiguaciones narrativas tienen para nuestras consideraciones ético-prácticas, un punto que nos parece de especial importancia y cuya reivindicación es más necesaria hoy que nunca.

El trabajo de Patricio Mena, "La lucidez del cuidado", supone un interesantísimo ejercicio fenomenológico sobre el cuidado, tomando como punto de partida la filosofía de Ricœur. Partiendo del análisis ricouriano sobre la atención, P. Mena expone como el cuidado contiene en sí mismo categorías tan importantes como la apertura a lo inesperado, la responsividad y la responsabilidad. El cuidado es un acontecimiento que implica una apelación, y que, por tanto, nos pone en el camino de la escucha. Todo lo cual lleva implícita una crítica al sujeto trascendental husserliano, que desde filosofías como la de Ricœur aparece duramente criticado en sus pretensiones. 
Con la aportación de Lydia Feito Grande, "Ricœur 'en' los comités de bioética: la práctica de la deliberación. Interdisciplinaridad y metáfora deliberativa", nos encontramos con uno de los trabajos más jugosos y potentes del libro. L. Feito tratará el problema concreto de los comités de bioética, con comentarios e indicaciones provenientes de la propia experiencia y de la filosofía de Paul Ricœur. El interés del trabajo es, por tanto, doble: se trata un tema real y relevante, pero a la vez se ponen en uso y a prueba las categorías ricœurianas sobre bioética. L. Feito, tras un breve recorrido por la historia de la joven disciplina bioética, expone su preferencia por una idea de "integración en la complejidad", frente a la ambigua concepción de la interdisciplinariedad. Respecto del tema concreto de los comités de bioética, L. Feito empezará diciendo que los conflictos no son necesariamente negativos, por cuanto muchas veces son generadores de sentido. Precisamente, el método deliberativo defendido por Ricœur parte del reconocimiento de que no podemos aspirar a verdades absolutas, solo a aproximaciones prudenciales. Esto no debe hacernos caer en el relativismo; y para ello la única solución es una ida y venida continua desde el plano normativo al caso concreto. El consenso, desde esta perspectiva, no es el fin último, sino que está supeditado a la creación de sentido, donde la imaginación y la metáfora se erigen como categorías clave. La bioética, concluye L. Feito, pasa a ser así algo más que una mera ética profesional, pudiendo aplicarse algunas de sus categorías a la política o a la educación.

La reflexión de Juan Masiá, titulada "Reconocimiento y responsabilidad", es una bella mezcla de sucinta exposición de la ética de Ricœur y testimonio personal de su relación con el hombre que fue Ricœur. El reconocimiento, en este caso, deja de ser una categoría filosófica y pasa a ser algo que transpira de las palabras de J. Masiá, al recordar al que considera, sin lugar a dudas, como un maestro. El texto de J. Masiá se centra en la importancia que tuvo la lectura 
para Ricœur. Un leer, que siempre fue un interpretar, y que por tanto no fue solo un leer textos, sino un leer personas, tradiciones y vidas. Un leer complejo y trufado de puntos de vista, que siempre enriquecía lo leído. El autor destaca asimismo la persistente reivindicación ricœuriana de la sagesse pratique, la cual, en continuidad con Aristóteles, evitaba caer extremos y privilegiaba categorías como la deliberación y la responsabilidad.

En "Los niveles del juicio médico y las tareas de un Comité Nacional de Bioética" de Antonio da Re, podemos ver otro buen ejemplo de aplicación bioética de las categorías ricœurianas. A. da Re expone la distinción entre los tres niveles del juicio médico: prudencial, deontológico y reflexivo, relacionando cada uno de los niveles con un filósofo paradigmático de cada corriente: Aristóteles con el prudencial, Kant con el deontológico y, en menor medida, Rawls con el reflexivo. Vemos así las posibilidades internas del pensamiento ricouriana para el diálogo entre distintas tradiciones, un potencial de valor incalculable.

Otro trabajo fundamental de los compendiados en el libro es el de Tomás Domingo Moratalla. Bajo el título "El 'efecto Ricœur' en bioética. La pequeña bioética de Paul Ricœur (hacia una bioética hermenéutica)", T. Domingo nos invita a pensar una "pequeña bioética” al hilo de la "pequeña ética” defendida por Ricœur; al mismo tiempo que se aboga por una bioética hermenéutica en la que la unión de ambos términos no sea casual sino mutuamente reafirmante. El método de Ricour, nos dirá el autor, si por algo se caracteriza es por su complejidad, por optar siempre por la vía larga. La bioética ricouriana, como su ética, será deliberativa, responsable y estará basada en la constitución narrativa y frágil del ser humano. El efecto Ricœur, que da título al trabajo, se refiere precisamente a este enriquecimiento y ganancia en complejidad, siempre basado en el diálogo, que la hermenéutica ricœuriana ha supuesto para la bioética, y de la que todavía puede seguir aprovechándose. Como termina 
diciendo el autor, y con lo que estamos plenamente de acuerdo, el efecto Ricœur es un efecto beneficioso que además importa mucho que se deje notar, por cuanto con él se ponen en juego algunos de los problemas más acuciantes de nuestro mundo actual.

Bioética y hermenéutica. La ética deliberativa de Paul Ricour es, en definitiva, una obra que hace justicia a la vida y obra de Paul Ricœur, reivindicando el enorme valor de su pensamiento. Muestra de ello es la vigencia de Ricour para la bioética, una disciplina que ejemplifica de la mejor manera los valores filosóficos defendidos por Ricœur: la aproximación compleja y alejada de reduccionismos, la responsabilidad ante los problemas del presente, la voluntad de diálogo y la preponderancia de la preocupación práctica. De este modo, el presente libro alcanza su más alto fin: convertirse en una irresistible invitación a la lectura de la obra de Paul Ricœur.

Financiación: Marcos Alonso Fernández es Becario de la Fundación Oriol Urquijo. 

Gonçalo Marcelo é licenciado em Filosofia e doutorado em Filosofia Moral e Política pela Universidade Nova de Lisboa. Atualmente, é bolseiro de pós-doutoramento (SFRH/ BPD/102949/2014) da FCT, desenvolvendo o seu projeto como membro do CECH (Universidade de Coimbra) e em parceria com a Departamento de Filosofia da Universidade de Columbia, sendo igualmente professor convidado na Católica Porto Business School.

César Correa Arias é doutorado em Ciências da Educação pela Universidad de Guadalajara / Université de Toulouse e pósdoutorado em Políticas do Ensino Superior pela EHESS (Paris). Atualmente, é Professor na Universidad de Guadalajara, Professor Associado do Seminário Regular Permanente sobre Políticas do Ensino Superior na EHESS (Paris) e membro do Sistema Nacional de Investigadores, financiado pelo CONACYT (México).

Patrícia Lavelle é mestrada em História Social da Cultura pela PUC-Rio e doutorada em Filosofia e Ciências Sociais pela EHESS (Paris), tendo desenvolvido pesquisa de pós-doutorado no Walter Benjamin-Archiv (Berlim) e no Fonds Ricœur (Paris). Atualmente é Professora na PUC-Rio e investigadora do Centre Georg Simmel (EHESS) e do Fonds Ricœur.

Tomás Domingo Moratalla é doutorado em Filosofia pela Universidad Pontificia Comillas. Atualmente, é Professor de Filosofia Moral na Faculdade de Filosofia da Universidad Complutense de Madrid. É igualmente correspondente do Fonds Ricœur em Espanha e Vice-Presidente da Associação IberoAmericana de Estudos Ricœurianos (ASIER). 
Publicado

com a coordenação

científica de

ASIER

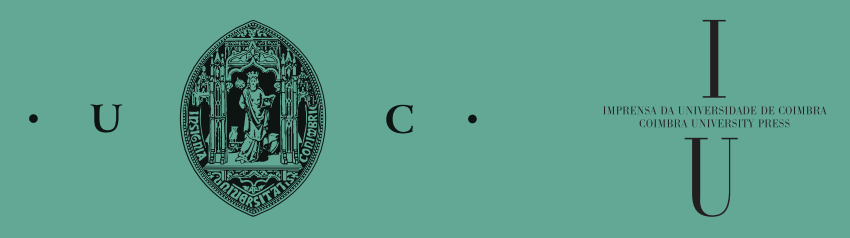

C • 